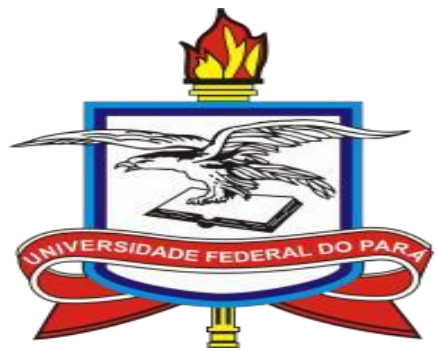

GOVERNO FEDERAL

UNIVERSIDADE FEDERAL DO PARÁ

INSTITUTO DE CIÊNCIAS DA EDUCAÇÃO

PROGRAMA DE PÓS-GRADUAÇÃO EM EDUCAÇÃO

DOUTORADO ACADÊMICO EM EDUCAÇÃO

LINHA DE PESQUISA EDUCAÇÃO, CULTURA E SOCIEDADE

ANA MARIA MACIEL CORRÊA

A TRAJETÓRIA dE UMA EDUCADORA E SUA PRODUÇÃO DIDÁTICOPEDAGÓGICA: ESTER NUNES BIBAS E A EDUCAÇÃO DO PARÁ 


\section{A TRAJETÓRIA DE UMA EDUCADORA E SUA PRODUÇÃO DIDÁTICO- PEDAGÓGICA: ESTER NUNES BIBAS E A EDUCAÇÃO DO PARÁ}

Tese de doutorado submetida ao Programa de Pós- Graduação em Educação da Universidade Federal do Pará - UFPA. Linha de Pesquisa Educação, Cultura e Sociedade, do Instituto de Ciências da Educação, como parte dos requisitos necessários à obtenção do Título de Doutor em Educação.

Orientador: Prof. Dr. Carlos Jorge Paixão 
Dados Internacionais de Catalogação na Publicação (CIP) Sistema de Bibliotecas da Universidade Federal do Pará

Gerada automaticamente pelo módulo Ficat, mediante os dados fornecidos pelo(a) autor(a)

C823t Corrêa, Ana Maria Maciel

A TRAJETÓRIA DE UMA EDUCADORA E SUA PRODUÇÃO

DIDÁTICO PEDAGÓGICA: ESTER

NUNES BIBAS E A EDUCAÇÃO DO PARÁ / Ana Maria Maciel Corrêa. - 2017. $256 \mathrm{f}$. : il. color.

Tese (Doutorado) - Programa de Pós-Graduação em Educação

(PPGED), Instituto de Ciências da Educação, Universidade Federal do

Pará, Belém, 2017.

Orientação: Prof. Dr. Carlos Jorge Paixão

1. Educação. Ester Nunes Bibas, Pensamento Educacional. História da Educação do Pará.. I. Paixão, Carlos Jorge , orient. II. Título 
A TRAJETÓRIA DE UMA EDUCADORA E SUA PRODUÇÃO DIDÁTICOPEDAGÓGICA: ESTER NUNES BIBAS E A EDUCAÇÃO DO PARÁ

ESTER NUNES BIBAS

(1888-1972)

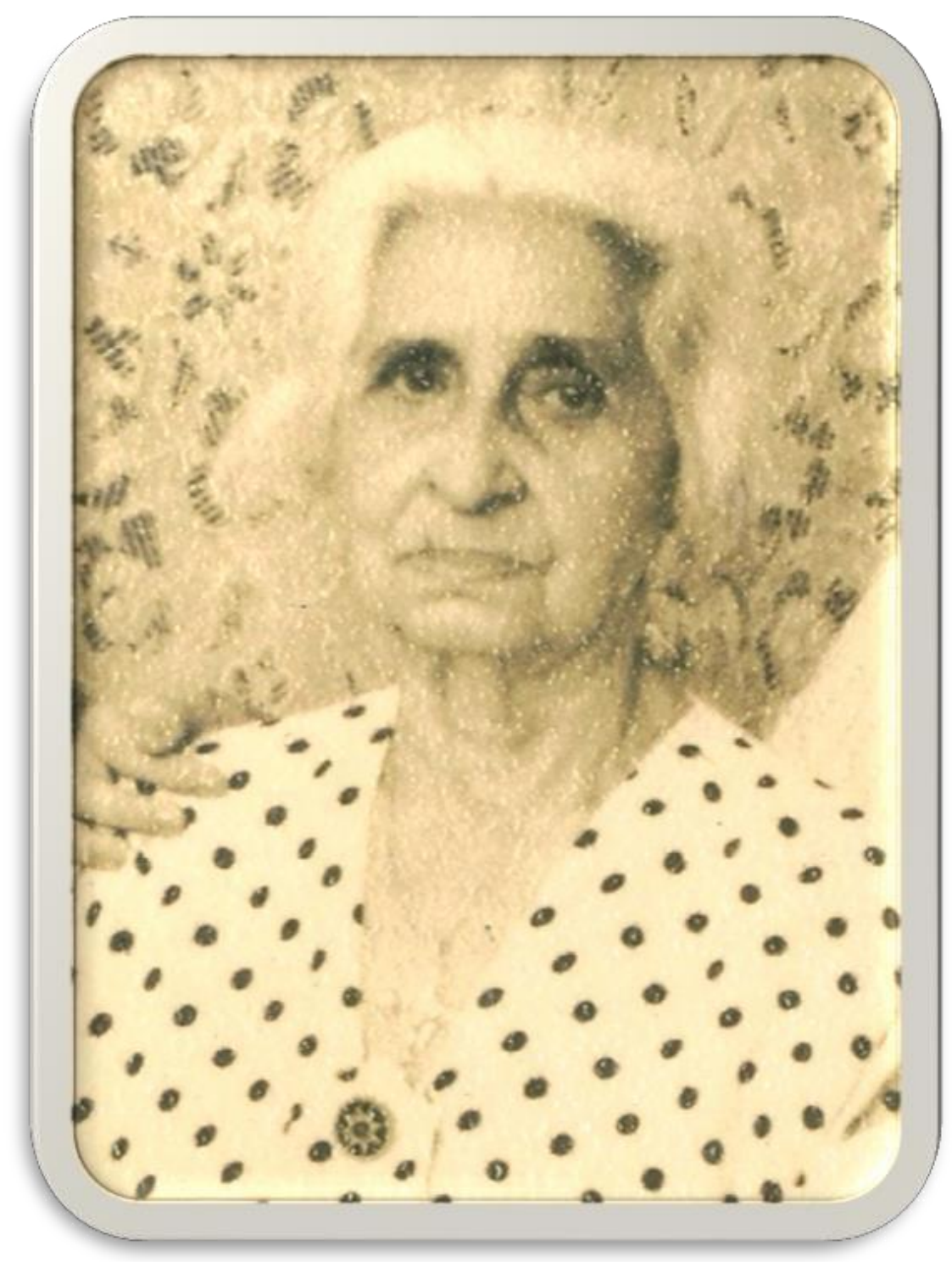




\title{
A TRAJETÓRIA dE UMA EDUCADORA E SUA PRODUÇÃO DIDÁTICO- PEDAGÓGICA: ESTER NUNES BIBAS E A EDUCAÇÃO DO PARÁ
}

\author{
Tese de doutorado apresentada ao \\ Programa de Pós-Graduação em \\ Educação da Universidade Federal \\ do Pará. Linha de Pesquisa \\ Educação, Cultura e Sociedade, do \\ Instituto de Ciências da Educação, \\ como requisito à obtenção do Título \\ de Doutor em Educação.
}

\section{BANCA EXAMINADORA}

Aprovada em: 14/ 11/ 2017.

Prof. Dr. Carlos Jorge Paixão: Orientador e Coordenador da Banca de Defesa da tese

Prof $^{a}$. Dra. Lúcia Isabel da Conceição Silva: Examinador Interno (PPGED. UFPA).

Prof. Dr. Damião Bezerra de Oliveira: Examinador Interno (PPGED. UFPA).

Prof $^{a}$. Dr ${ }^{a}$. Lucélia de Moraes Bassalo: Examinador Externo (PPGED. UEPA).

Prof. Dr. Manoel Ribeiro de Moraes Júnior: Examinador Externo (PPG. UEPA 
"O Senhor Reina; está vestido de majestade; o Senhor está vestido de seu poder; o mundo também está firmado, e não poderá vacilar.

O teu trono está firme desde então; tu és desde a eternidade. Os rios levantam o seu ruído, os rios levantam as suas ondas.

Mas o Senhor nas alturas é mais poderoso do que o ruído das grandes águas e do que as grandes ondas do mar.

Mui fiéis são os teus testemunhos; a santidade convém à tua casa, Senhor para sempre." 
Ao Milton Lopes Corrêa (In Memoriam), à Maria Célis Maciel Corrêa, À Ariany Corrêa e Alanna Corrêa! Com amor e carinho! 


\section{AGRADECIMENTOS}

Agradecemos primeiramente ao Deus, criador dos Céus e da Terra! Ao Deus Pai, ao Deus Filho e ao Espírito Santo, Socorro bem presente nas horas de angústia e indecisão diante do caminho a ser seguido. Agradecemos a inspiração, a orientação e a capacitação para saltarmos muralhas e atravessarmos mares com pés enxutos e realizar esse empreendimento acadêmico.

Ao professor Dr. Carlos Jorge Paixão pela atenção, pela orientação e pelo crédito de confiança para a construção deste projeto acadêmico, em meio a tantas dificuldades em que se localiza a escritura feminina e de sobremaneira, ao se tratar de uma escritura de uma mulher nortista, paraense, escritora de obras didáticas, enquanto produção cultural local e periférica. Professor Carlos, meus agradecimentos pela acolhida e pelosensinamentos.

À Secretaria de Estado de Educação, à Secretaria Adjunta de Educação e a Gerência de Valorização do servidor pela liberação para a conclusão desta pesquisa.

Aos colegas do Programa de Pós-Graduação em Educação, linha Educação, Cultura e Sociedade, que ao longo do curso estivemos lado a lado trocando ideias, experiências e aprendizados.

Às minhas filhas: Ariany Corrêa, Alanna Corrêa. À minha mãe e irmãs pela presença e pelo apoio ao longo desta caminhada; pois, a família é o bem maior; o projeto de Deus em nossas vidas.

À minha prima: Maria Natália dos Santos, amiga de todas as horas.

À amiga Izabel da Conceição Soares da Costa pelo aprendizado contínuo na jornada profissional que nos proporcionou ir além dos entraves institucionais.

À amiga Floripes Fachada, embora distante do Brasil, esteve sempre presente com seu apoio de irmã espiritual.

Ao professor Heraldo Meireles pelo apoio amigo e colaborador na revisão e organização estética desta produção acadêmica. 


\section{RESUMO}

A tese aborda o pensamento educacional da professora paraense Ester Nunes Bibas, circunscrito na coletânea Didático-Pedagógica de sua autoria, intitulada, Páginas Brasileiras; endereçada ao ensino primário do Estado do Pará. Considerando que a autora e sua produção didática encontram-se ocultas no contexto atual em face de escassos registros que denotam uma presença-ausência e um lugar de invisibilidade desta professora escritora na história da educação local; a tese propõe romper com esse condicionamento histórico, ao direcionar todo processo investigativo para desvelar a trajetória pessoal, profissional e intelectual desta professora escritora com a intenção de apreender e compreender as contribuições e o lugar desta educadora e seus livros didáticos no seu tempo-lugar para a história da educação do Pará. Tal processo se pautou na localização de documentos, de escritos poéticos da escritora e de relato familiares, ainda que indiciários, como sinalizadores da trajetória desta educadora. Com relação à apreensão e a compreensão do pensamento educacional de Ester Nunes Bibas, o terceiro e o quinto livro da coletânea Páginas Brasileiras (1950-1960), então, localizados, tornaram-se corpus de estudos, análises e compreensão das marcas materiais, como elementos reveladores dos propósitos e dos sentidos educacionais trazidos pelos livros didáticos citados; assim como pela análise discursiva dos gêneros textuais selecionados para a apreensão dos discursos e dos interdiscursos que circunscrevem o pensamento da mulher, professora e escritora Ester Nunes Bibas no âmbito da educação. Todo esse percurso da pesquisa, do estudo e dos processos de análise transitou pelos caminhos da história cultural, entre os quais, a história da mulher, história intelectual, história biográfica, história de vida de professores e saberes docentes, pelo campo da linguagem, da literatura e da linguística, como subsídios teórico-metodológicos e suas interfaces com a história da educação com vistas à construção de uma narrativa histórica sobre a vida e o pensamento educacional da professora normalista, Ester Nunes Bibas, como sujeito-objeto, sob o olhar de sujeito epistêmico do campo da educação paraense.

Palavras chave: Educação, Ester Nunes Bibas. Pensamento Educacional. História da educação do Pará. 


\begin{abstract}
The thesis discusses the educational thought of Professor paraEster Nani Queens, circumscribed on didactic-pedagogical of your authorship entitled, Brazilian Pages; addressed to the primary education of the State of Pará. Considering that the author and your production didactics are hidden in the current context in the face of scant records that denote a presenceabsence and a place of invisibility of this writer in the history of teacher education; the thesis proposes breaking with this historical conditioning, to direct all investigative process to unveil the personal, professional and intellectual trajectory of this teacher writer with the intention to seize andunderstand the contributions and this educator and your textbooks in your time-place for the history of education.Such a process is marked in locating documents, poetic writings of author and family, still reporting that indication, as flags from the trajectory of this educator. With respect to the apprehension and understanding of the educational thought of Ester Nani Queens, the third and the fifth book of Brazilian Pages (1950-1960), then located, became corpus of study, analysis and understanding of materials, marks as elements developers of educational purposes and directions brought by the textbooks cited; as well as the discursive analysis of textual genres selected for the seizure of the speeches and the interdiscursos that limited women's thinking, teacher and writer Esther Nunes Queens in education. All this route of research, study and analysis processes moved the paths of cultural history, including the women's history, intellectual history, biographical history, life story of teachers and lecturers, knowledge in the field of language, the literature and Linguistics, theoretical and methodological as subsidies and its interfaces with the history of education for the construction of a historical narrative about life and the educational thought of teacher for primary and secondary schools, Ester Nani Queens, subject-object, under the gaze of epistemic subject of field of education para.
\end{abstract}

Keywords: Education. Esther Nunes Bibas. intellectual trajectory. History of Pará education 


\section{LISTA DE QUADROS}

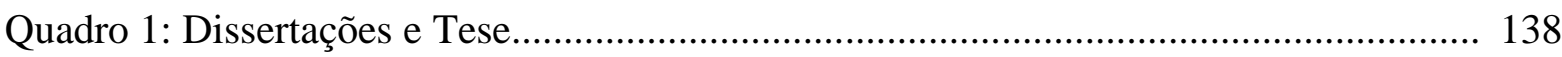

Quadro 2: Descrição Material do Terceiro livro............................................................... 144

Quadro 3: Descrições de áreas, Gêneros e Temas......................................................... 148

Quadro 4: Descrição Material do Quinto livro................................................................. 154

Quadro 5: Vinculações políticas, educacionais, filosóficas, literárias............................... 161

Quadro 6: Gêneros textuais selecionados para análise................................................. 184 


\section{LISTA DE FIGURAS}

Figura 1 - Jornal "O Vigiense" ......................................................................... 90

Figura 2 - Jornal "Folha do Norte" .......................................................................... 105

Figura 3 - Ronda Literária- Folha do Norte............................................................. 106

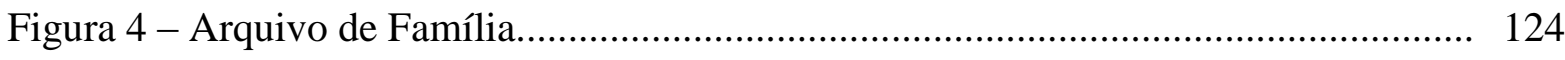

Figura 5 - Capa e Contracapa Terceiro Livro.......................................................... 125

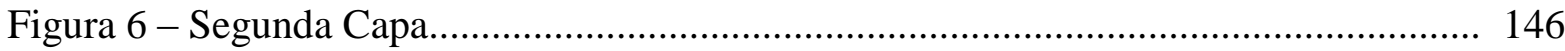

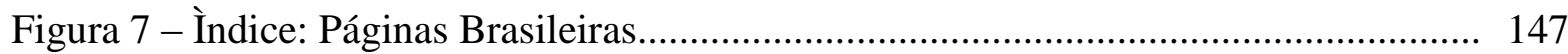

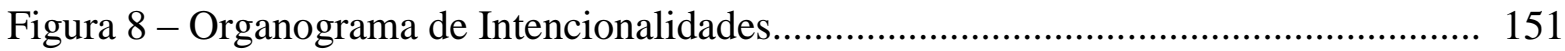

Figura 9 - Gêneros Textuais - Páginas Brasileiras...................................................... 152

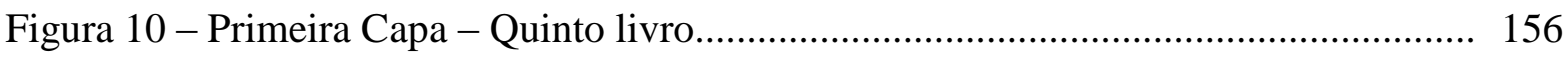

Figura 11 - Segunda Capa - Quinto livro.......................................................... 158

Figura 12 - Índice: Páginas Brasileiras - Quinto livro............................................. 160

Figura 13 - Gêneros textuais do Quinto livro............................................................. 163

Figura 14 - Voz da Amazônia................................................................................... 212 


\section{LISTA DE SIGLAS}

CAPES Coordenação de Aperfeiçoamento de Pessoal de Nível Superior

CINBESA Companhia de Tecnologia de Informação de Belém

CNLD Comissão Nacional do Livro didático.

COBPE Centro Brasileiro de políticas educacionais.

COLTED Comissão Nacional do Livro Técnico e do Livro Didático.

FENAME Fundação Nacional do Material escolar.

INEP Instituto Nacional de Estudos e Pesquisas Anísio Teixeira.

MEC Ministério da Educação.

PUC-RIO Pontifícia Católica do Rio de Janeiro.

SEDUC Secretaria de Estado de Educação.

SEMEC Secretaria Municipal de Educação.

UERJ Universidade Estadual do Rio de Janeiro.

UESB Universidade Estadual da Bahia.

UFMA Universidade Federal do Maranhão.

UFMG Universidade Federal de Minas Gerais.

UFPA Universidade Federal do Pará.

UFSC Universidade Federal de Santa Catarina.

UNICAMPI Universidade Estadual de Campinas.

USP Universidade de São Paulo - SP. 


\section{SUMÁRIO}

INTRODUÇÃO......................................................................................... 15

I O LUGAR DOS NOVOS SUJEITOS NO CAMPO HISTORIOGRÁFICO: Mulheres, Professoras, Escritoras.................................................................. 35

1.1 A EDUCAÇÃO E O CAMPO HISTORIOGRÁFICO: EMBATES E POSSIBILIDADES.............................................................................

1.2 MULHERES, PROFESSORAS E ESCRITORAS: NOVOS SUJEITOS DO CAMPO EDUCACIONAL................................................................... 40

1.2.1 Mulher, Educação e a Voz do Silêncio.................................................... 40

1.3 O MAGISTÉRIO PRIMÁRIO SOB AS MARCAS DA PRESENÇA FEMININA............................................................................................ 46

1.3.1 Do Lar à Escola e a Profissionalização da mulher no Magistério Primário... 48

1.3.2 A feminização do Magistério e a Subalternidade da mulher........................... 52

1.3.3 Relações de Poder e os mecanismos de controle da Professora Primária....... 58

1.3.4 O Magistério Primário como entre lugar do possível: Lócus da emergência de novas Identidades femininas.

II TRANSITANDO PELOS CAMINHOS DA HISTÓRIA CULTURAL: PORTE TEÓRICO-METODOLÓGICO........................................................ 69

$\begin{array}{llllll}2.1 & \mathrm{O} & \text { SUJEITO-OBJETO } & \text { SOB } & \text { A PERSPECTIVA } & \text { DA NOVA }\end{array}$ HISTÓRIACULTURAL................................................................................ 69

2.2 ANÁLISE DE GÊNERO DE DISCURSO SOB A PERSPECTIVE BAKHTINIANA

2.2.1 Bakhtin e a filosofia da linguagem: campo referencial para análise do discurso.

2.2.2 A Criação Verbal e o Gênero do Discurso......................................................................

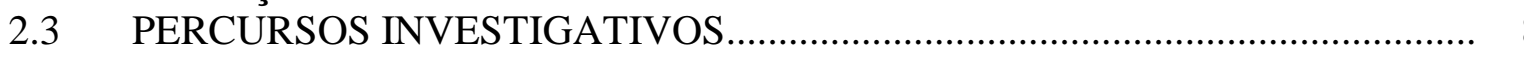

III A TRAJETÓRIA DA PROFESSORA ESTER NUNES BIBAS......................... 92

3.1 ESTER NUNES BIBAS SOB O OLHAR(AUTO)BIOGRÁFICO....................... 95

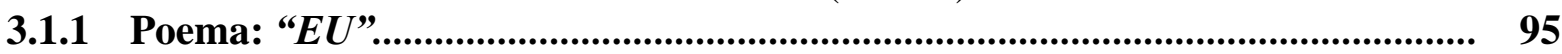

3.2 ESTER NUNES BIBAS: VIDA E OBRA..................................................... 98

3.3 CAMINHOS TRANSITADOS POR ESTER NUNES BIBAS ........................... 103

3.3.1 Pelos Caminhos do Privado: A vida Familiar......................................................... 104

3.3.2 Pelos Caminhos Literários..................................................................................... 106

3.3.3 Pelos Meandros da Política: Da defesa de direitos femininos ao apoiopartidário................................................................................................................. 110

3.3.4 Pelos Caminhos da Educação: Normalista, Professora e Escritora de Livros didáticos

IV ANÁliSE MATERIAL DO LIVRO DIDÁTICO "PÁGINAS BRASILEIRAS" ESTER NUNES BIBAS............................................................ 127

$4.1 \quad$ ESTUDOS SOBRE OS LIVROS DIDÁTICOS.................................................. 130

4.2 O LIVRO DIDÁTICO NO ESTADO DO PARÁ................................................... 136

4.3 A MATERIALIDADE DOS LIVROS DIDÁTICOS "PÁGINAS BRASILEIRAS"- TERCEIRO LIVRO (1967) E PÁGINAS BRASILEIRAS (SELETA), QUINTO ANO PRIMÁRIO (1957)................................................. 140

4.3.1 A Materialidade do Livro "Páginas Brasileiras"- Terceiro Livro....................... 143 
4.3.2 A Materialidade do Livro "Páginas Brasileiras" - Quinto Livro

$V$ O PENSAMENTO EDUCACIONAL DE ESTER NUNES BIBAS: DISCURSOS E INTERDISCURSOS........................................................................ 169

5.1 O LÓCUS ENUNCIATIVO DA PESQUISA................................................... 170

5.2 BAKHTIN E O CAMPO DA LINGUAGEM................................................. 173

5.3 ANÁLISE DISCURSIVA DOS GÊNEROS TEXTUAIS NO LIVRO DIDÁTICO "PÁGINAS BRASILEIRAS"...................................................... 181

5.3.1 Apreensões Discursivas dos Gêneros Textuais em "Páginas Brasileiras" Terceiro Livro.............................................................................................. 185

5.3.2 Análise Discursiva do Quinto Livro "Páginas Brasileiras"............................... 204

5.3.3 Uma Mulher do seu Tempo-lugar................................................................. 215

5.3.4 Mulher Letrada: Sujeito epistêmico......................................... 218

5.3.5 A Palavra Empenhada: discursos autorizados............................................... 220

CONSIDERAÇÕES FINAIS............................................................................ 223

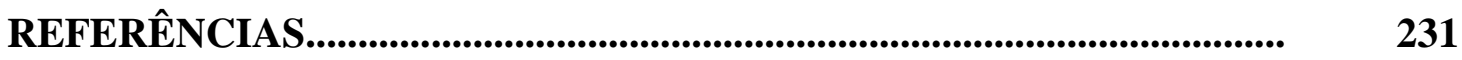

ANEXOS................................................................. 243 


\section{INTRODUÇÃO}

A presente tese se reporta à apreensão e compreensão do pensamento educacional da professora Ester Nunes Bibas, enunciado em seus discursos pedagógicos presentes na produção didática de sua autoria intitulada "Páginas Brasileiras". São livros didáticos publicados pela Editora do Brasil S.A, entre as décadas de 1950-1960, e formavam uma coletânea composta por cinco livros direcionados para as cinco séries do ensino primário e que ao longo de oito edições como afirma o professor Clóvis Meira (1988), se constituíram em orientações didático-pedagógicas às práticas docentes e conteúdos escolares disponibilizados por meio de gêneros textuais de sua autoria e de outros autores, como mediadores dos processos de leitura e aprendizagem dos alunos do ensino primário no estado do Pará.

A tese se situa no campo da história da educação do estado do Pará e traz a intencionalidade de propiciar a visibilidade do pensamento educacional e a escrita didática desta professora normalista para o campo da educação primária. Para o alcance dessa intenção, todo procedimento investigativo se direciona para apreender e compreender a trajetória desta mulher, professora e escritora de livros didáticos, seus caminhos transitados, sua formação intelectual, seus engajamentos, a conjuntura nacional- local cultural, educacional, histórico-ideológico.Como aspectos interferentes na constituição desta mulher, professora e escritora, assim como, identificar os aportes epistemológicos apropriados, defendidos e sinalizados em sua escrita didática.

Os interesses que motivaram a pesquisadora empreender esta pesquisa sobre a temática "Mulher Professora e Intelectual do campo da educação" inicialmente remete à própria trajetória profissional na Secretaria de Estado de Educação do Pará, como professora e técnica em gestão pública. Funções que propiciaram um contato direto com as escolas estaduais e municipais localizadas na cidade de Belém. E nesse atuar, uma questão bem presente e percebida junto ás escolas nos eventos de formação de professores e ou de alunos: a dificuldade apresentada pela direção, corpo docente e discente em conhecer os patronos que nomeiam as suas escolas E quando se trata das escolas com nomes de professoras, se conhece apenas o nome ou uma história sintética (quando escrita) que não dá conta da trajetória e das contribuições dessas educadoras para o campo da educação local. Nessa caminhada identificamos escolas que são nomeadas apenas pelo prenome de professoras; fato que nos levou a questionar essa situação nos momentos de idas e vindas por escolas que receberam como patronos, o nome de professores, professoras, outros sujeitos ou outras denominações. 
No contexto atual, a história de professoras primárias localizadas no passado encontrase esquecida e assim imersa num contexto de silenciamento por conta da ausência de registros documentais, e somente emergem desse lugar de ocultação pelo estudo e análise de rastros, vestígios trazidos por fragmentos escritos e por rememorações de familiares e amigos. O lugar de invisibilidade de professoras se justifica no cenário educacional brasileiro e local pela exclusão da experiência e da intelectualidade de professoras normalista. E assim, todo esse processo de apagamento das experiências de professoras e de escritoras no âmbito da educação brasileira está diretamente vinculado à ocultação da mulher e de outros grupos sociais classificados e posicionados pelos processos de desigualdade e exclusão social, que permearam as representações e o lugar do masculino e do feminino na sociedade brasileira, amazônica e paraense. Sujeitos que ao longo da história mantiveram-se ocultos, subalternos, sem reconhecimento e destituídos da condição de sujeitos históricos.

O Brasil no transitar do século XIX para o século XX, vivenciou um momento de entusiasmo direcionado ao acesso do país ao mundo moderno e em direção a essa inserção, a implantação da era republicana, que além de disseminar os novos ideários da modernidade, passou a defender a importância da educação nacional com vistas à apropriação da língua nacional e da escrita, compreendidas nesse momento, como referências de uma nação autônoma e soberana no âmbito político e intelectual. Todavia, neste cenário de modernização permaneceram as marcas da exclusão de grande parcela da população e, de forma acentuada a formação desigual de meninas e moças, que por muito tempoa exclusão da autoria feminina.

Embora, se reconheça que a constituição da mulher letrada esteve diretamente associada ao acesso da mulher à educação, à leitura e à escrita de forma mais ampliada nesta transição política, em que a educação se tornara condição precípua para a efetivação da nacionalidade e para o alcance da modernização e do progresso da nação brasileira. A intelectualidade feminina emere pela capacidade criativa do feminine que se deu pelo exercício da leitura e da escrita sobre si e sobre o mundo; o que levou a mulher brasileira a exercitar a escrita e a publicar seus textos. Nesses escritos, as mulheres escritoras registraram e publicizaram seus pensamentos, suas angústias, seus sonhos, projetos e bandeiras de lutas, como sinalizadores de uma postura rebelde ou libertária de algumas mulheres que se contrapunham aos valores e padrões culturais patriarcais, limitadores dos avanços do sujeitomulher. 
A Secretaria de Estado de Educação através de seu Portal de Serviços ${ }^{1}$, página principal, apresenta para a região metropolitada de Belém um total de 350 escolas do ensino fundamental e médio, sem levar em conta o número de escolas anexas. Nesse quadro demonstrativo, identifica-se que 195 escolas receberam nomes de homens historicamente situados no desempenho de funções políticas, literárias, militares, religiosas e de professores. Correspondendo a um percentual de 55,7\% das escolas com nomes de homens conhecidos e reconhecidos por sua atuação a nível nacional e local. As 109 escolas receberam nomes de mulheres, entre as quais, professoras, esposas e ou mães de políticos e por nome de santas, correspondendo a 31,1\% a nomeação feminina, e as demais, 13,2\% das escolas, recebem outras denominações. Os dados mencionados fornecem uma visibilidade em meio à prevalência do masculino, o número significativo de mulheres professoras, que nomeiam as escolas da grande Belém. No entanto, são mulheres pouco conhecidas por se encontrarem ocultas por conta da invisibilidade de suas atuações no campo da educação.

A Secretaria Municipal de Educação de Belém, através do portal do CINBESA$2017^{2}$ - Companhia de tecnologia de Informação de Belém, disponibiliza o registro de 59 escolas municipais em Belém. Entre as quais, 33 escolas receberam nomes de homens na condição de professores, políticos e literatos, e uma representatividade de 55,9\% da presença masculina; 20 escolas municipais são nomeadas por mulheres predominantemente professoras primárias e professoras com destaque no campo da educação, o que sinaliza 33\% da presença feminina nesse cenário escolar. Somente 06 escolas municipais, que correspondem à 3,54\% recebem outras denominações. Transparecem num primeiro olhar como indicativos quantitativos, numéricos, mas remetem á outras observações, reflexões e inquisições investigativas para o campo da educaçãolocal.

Essa preocupação inicial em relação à invisibilidade da mulher professora ganhou maior relevância quando participamos do Projeto de Pesquisa: Um Estudo do Pensamento Educacional de Mulheres Latino-Americanas do século XIX. Projeto que esteve sob a execução da Universidade Federal do Pará; Instituto de Ciências da Educação - ICED, coordenado pela Prof ${ }^{a}$. Dr ${ }^{a}$.Sônia Maria da Silva Araújo.Nossa vinculação a esse projeto de pesquisa ocorreu no periodo letivo de 2014-2015, enquanto aluna da disciplina Intelectuais da Educação-PPGED-UFPA.

Ao participarmos dos processos de coleta de dados com vistas à localização de

\footnotetext{
${ }^{1}$ Secretaria de Estado de Educação - Portal de Serviços, pesquisa atualizada em 13/09/17.

${ }^{2}$ Pesquisa realizada no CINBESA-Belém, atualizada em 13/09/17.
} 
mulheres Latino-americanas, escritoras vinculadas à área da educação e localizadas historicamente entre os séculos XIX e XX, nos motivou a empreender pesquisas paralelas com o objetivo de localizar mulheres professoras e escritoras do campo da educação no estado do Pará, focalizaando mulheres nascidas no séculoXIX-XX. A partir dessa coleta inicial de dados e pela associação aos estudos ligados à história da mulher, produzimos o artigo intitulado "Escritas e Escrituras Femininas na Sociedade Paraense da Borracha: 1850 - 1900”, apresentado à disciplina Seminário de Tese I, em junho de 2014, como primeira aproximação com a temática a ser proposta e investigada pela tese, produzimos outro artigo, enquanto primeira escrita a respeito de nosso sujeito-objeto: A Educação em Tempos Republicanos na Obra de Ester Nunes Bibas, apresentado no VIII Encontro Maranhense de História de Educação, promovido pela UFMA, realizado em 12 a 15 de maio de2015.

Produzimos o artigo "Rompendo o Silêncio e a Ocultação da Mulher Ester Nunes Bibas: Educadora e Escritora na história da educação no estado do Pará”, apresentado como trabalho final da disciplina "Intelectuais e Circulação de ideias em Educação", PPGEDICED, novembro de 2015, como resultante de registros, ainda que parcelados e em direção ao aprofundamento dos estudos.

A tese começou a ser formatada a partir da localização da professora Ester Nunes Bibas, originária do município de Vigia-Pará, ao apresentar um perfil então vinculado à história de mulheres professoras e escritoras no campo da educação no estado do Pará. A escolha desta professora como sujeito-objeto de investigação se deu inicialmente pela localização de dados biográficos, ainda que fragmentados, e pela localização de dois exemplares de sua coletânea didática Páginas Brasileiras, referentes ao terceiro e o quinto livro desta coletânea. Outro fator que nos impulsionou a efetivar a proposição desta tese está relacionado à ausência de pesquisas a respeito da atuação e da contribuição de mulheres educadoras no estado do Pará no transitar do século XIX para o século XX. A partir de então, delimitamos nosso estudo investigativo para a busca de referenciais, fatos e registros que norteassem a construção de uma narrativa histórica cuja intenção se delineia pelo resgate da vida e do pensamento intelectual da professora paraense Ester Nunes Bibas (1888-1972), autora dos livros didáticos "PaginasBrasileiras", impressos e circulados entre 1950-1960.

Ao propor uma construção de uma narrativa histórica sob o formato de uma biografia intelectual dessa autora paraense, compartilhamos com as observações de Chartier (2015), pautadas nos posicionamentos de Veyne (1971) e Certeau (1975), para a compreendermos a (respeito da narrativa histórica: "Em Veyne (1971), a história é antes de tudo, um relato e o que se denomina explicação não é mais que a maneira de a narração se organizer em uma 
tramacompreensível. Por sua vez, Certeau (1975) afirma que o discurso historic pretende dar um conteúdo verdadeiro sob a forma de uma narração a cerca de um passado, não como foi plenamente, pois, a construção de uma narrative histórica perpassa pelos pensamentos, pela fala, e pelos sentidos dos fatos. (CHARTIER, 2015, p. 11, apud VEYNE, 1971, CERTEAU,1975).

Sobre a centralidade desta questão, Chartier (2015), chama a atenção para a tomada de consciência entre o passado e sua representação, ou seja, "A representatividade desse passado que não existe mais" e sobre o qual se constrói uma narrativa histórica. Nessa reflexão, nos encaminhamos para a construção de uma narrativa que localize a autora Ester Nunes Bibas, seu pensamento educacional, mediante dados coletados e pelo estudo dos livros didáticos Páginas Brasileiras em seus aspectos materiais e discursivos; além da percepção do sistema educacional nacional-local, os sujeitos envolvidos no processo de escolarização, o contexto cultural, histórico-ideológico situado pela obra didática de Ester Nunes Bibas.

A tese centra-se no estudo da atuação e das proposições educacionais de um sujeito particular e encaminha um projeto investigativo que pretende estudar num tempo-lugar o transitar de uma mulher intelectual da educação, localizada num estado e numa região brasileira distanciada dos grandes centros do país e nesse condicionamento periférico, focalizar as intercorrências das tendências ou vertentes da educação nacional e local no pensamento desta professora normalista.

No desenvolvimento desta pesquisa observamos que a professora Ester Nunes Bibas se situa historicamente entre o grupo de mulheres que estabelece uma ponte entre o século XIX para o século XX e, que apresenta notoriedade no campo da educação ao longo de sua trajetória histórica como professoras normalistas. Todavia, suas histórias de vida e suas produções intelectuais se encontram silenciadas e desconhecidas na atualidade. São mulheres educadoras e escritoras na área da educação, cujas experiências e proposições pedagógicas não foram referenciadas pela história da educação local, dessa maneira, apenas localizadas no seu tempo de atuação. No contexto atual, são rememoradas por rastros e vestígios trazidos por lembranças de familiares, amigos, ex-alunos e de fragmentos escritos. Essa condição de invisibilidade das professoras se justifica pelo cenário educacional brasileiro e local que excluiu a experiência e a intelectualidade de professoras normalistas pelo não reconhecimento de seus escritos e de seu pensamento educacional. Assim, o encobrimento da professora e da escritora no âmbito da educação brasileira e local está diretamente vinculada à ocultação da mulher e de outros grupos sociais classificados e posicionados pelos processos de desigualdade e exclusão social, que permearam as representações e o lugar do masculino e do 
feminino na sociedade brasileira, amazônica e paraense. Mulheres que ao longo da história mantiveram-se ocultas, subalternas, sem o direito à fala e a escrita, destituídas da condição de sujeitos históricos. Nesse lugar de encobrimento da mulher, a trajetória e as contribuições pedagógicas de professoras normalistas por muito tempo foram mantidas ocultas no cotidiano escolar e invisíveis no cenário educacional mais ampliado; como esclarece Nóvoa (2013), quando afirma que:

\footnotetext{
A história de vida de professores e suas contribuições tornaram-se uma espécie de "paradigma perdido" para o campo da pesquisa educacional e dessa maneira se faz necessário reafirmar, dizer e de se contar sobre a profissão docente, a partir de uma compreensão de toda a complexidade humana e científica que envolve o fazer docente (NÓVOA, 2013, p. 1).
}

Sob o olhar de Nóvoa (2013) a apreensão do saber epistêmico do professor primário nos aponta para uma investigação que possibilite compreender as dimensões pessoais e profissionais, que se entrelaçam na constituição identitária de ser professor (a). Pois, "ser professor(a) obriga a opções constantes, que "cruzam a nossa maneira de ser com a nossa maneira de ensinar, (como dimensões do pessoal e do profissional), que desvendam a nossa maneira de ensinar (e) a nossa maneira de ser". Como dimensões inseparáveis que se interpenetram no processo constitutivo do sujeito. (Idem)

Nóvoa (2013) reconhece a importância dos estudos no campo educacional ancorados na trajetória biográfica de professores(as), como marco referencial para a renovação das formas de pensar a atividade docente. Uma apreensão que se dá a partir do vivido e da experiência, como dimensões demarcadoras da singularidade da vida e do universo profissional de professores(as). Nessa percepção, a trajetória biográfica ou a história de vida "recoloca" o lugar das professoras e professores como sujeitos construtores de práticas e de saberes, e lócus privilegiado, onde o professor (a) se constrói como sujeito produtor do saberfazer na cotidianidade do espaço escolar. Assim, a história de vida de professores "evoca" para o campo educacional, as conexões entre a pessoa do professor (a), as práticas educativas, o pensar e o fazer pedagógico desse sujeito produtor de cultura (Ibidem).

Nessa compreensão, a presente tese traz: A Trajetória de uma Educadora e sua Produção Didático-Pedagógica: Ester Nunes Bibas e a Educação no Pará.. Trata-se de uma proposição acadêmica que estabelece articulações com o conjunto de pesquisas sobre o resgate da atuação de mulheres escritoras localizadas no transitar do século XIX para o século XX. Reportando-se para o campo de estudos investigativos no âmbito da Histórica Cultural e suas inflexões para o campo da intelectualidade, da história da mulher, história da educação, 
história do livro didático, que nesta proposição se articulam para a valorização da atuação e produção intelectual de mulheres na área da educação.

Considerando o contexto de invisibilidade da autora e de sua obra didática, a tese parte da seguinte questão norteadora: Que lugar ocupa/ou a educadora Ester Nunes Bibas e sua produção didático-pedagógica no contexto educacional do Pará? Considerando-se o contexto social, cultural, político e ideológico da sociedade paraense em que Ester Nunes Bibas se constitui mulher, professora e escritora e, nesse espaço social do final do século XIX ao século XX, entender este lugar e ou este entre-lugar em que transita a mulher professora e a escritora de maneira fronteiriça para ascender ao campo da intelectualidade. Considerando-se que a atuação e a produção desta educadora alcançaram uma importância e reconhecimento no campo educacional paraense. Ester Nunes Bibas publicou os livros didáticos pedagógicos intitulados "Páginas Brasileira"; e ao longo de sete edições subsidiaram as práticas docentes e o processo de ensino-aprendizagem de alunos do ensino primário do estado do Pará. Esta produção didática foi transcrita para o Braille para a leitura de alunos da Escola Álvares de Azevedo, unidade especial para atendimento de alunos com deficiência visual no ano de 1963, fato, revelado em uma carta escrita por Vânia Bibas, neta da escritora e impressa no Terceiro Livro de Páginas Brasileiras e na imprensa local; o que demonstra o reconhecimento desta obra didática após anos contínuos de circulação e nesse momento ganha um referendo maior ao ser transcrita para o braile.

Apostando na importante atuação dessa professora periférica, do estado do Pará, referendado pelo ofício docente, pelo trânsito por outros caminhos, outras atuações, E que este produzir no âmbito da escrita impressa deslocaram essa mulher para o espaço público como por exemplo, a produção literária, produção de livros, pronunciamentos, escritos em jornais de sua época. Assim, a partir do fazer pedagógico e da apropriação de saberes, a emergência de um novo fazer feminino em novos espaços sociais, nos quais, as mulheres passaram a circular com maior visibilidade no tempo. Nessa apreensão, apresentamos como questionamentos metodológicos são postos a essa vertente historiográfica relacionados à ausência de fontes e registros em arquivos públicos e privados sobre à atuação de mulheres; condicionantes então vistos como impasses ao trabalho de investigação e estudo sobre a atuação de mulheres. Entretanto uma saída é trazida pela análise dos rastros femininos em registros escritos ou de outra natureza que permitem perceber seus atos e condutas circunscritas aos parâmetros sociais ou fora desses padrões estabelecidos culturalmente. Assim, se de um lado, nos defrontamos com ausência de fontes, registros e relatos sobre a trajetória feminina, tal ausência de fontes, na verdade confirma a relação imbricada com o 
processo de ocultação e o anonimato da mulher; por outro lado, os escritos e os registros encontrados que enaltecem os privilégios masculinos, são referendos do poder e domínio do homem e, fator importante para a produção e manutenção da invisibilidade da mulher.

São dificuldades que encaminham os pesquisadores dessa área da história para a busca de fontes alternativas em arquivos particulares, que permitem o perceber da mulher em sua cotidianidade, em sua atuação no campo privado, caracterizando-se como são recortes de informações que permitem observar e o retratar das interferências provocadas pela atuação de mulheres, ainda que imersas num cenário de objeções.

A mulher se encontrava nos arquivos (de forma) natural [...] Pois, evidentemente, ela estava lá todo o tempo. Ela estava importante, necessária, ao mesmo tempo pacificadora e revolucionária. Ela era presença eloquente, trabalhadora, móvel, agitada, fecunda, desejante e desejada. Presença em relação com o mundo masculino [embora diante] a supremacia masculina: O político e a memória (DEL PRIORE, 2012, p. 225).

Um desvelar trazido por Del Priore (2012) a respeito da invisibilidade da mulher, mediante uma presença-ausência num mundo tipicamente masculino, em que sua materialidade é fugaz, fluida, quase insólita e sua presença torna-se concreta e palpável diante dos desejos e das prescrições da mentalidade patriarcal, que se mantém dominante pela ocultação e pelo não reconhecimento das contribuições da mulher. Uma representatividade da mulher reforçada pelo cenário e pelos fatos sociais que pontuam a condição feminina. Del Priore (2012) aponta um novo direcionamento ao campo da história da mulher pela adoção de uma percepção mais ampliada sobre a história de homens e mulheres localizados nos estratos "de baixo", os excluídos da história; sujeitos sem voz e direitos de cidadania plena.

Os estudos empreendidos com este propósito, a partir das décadas de 1980, 1990 e $2000^{3}$, possibilitaram a visibilidade deste campo de pesquisa e a atuação de professoras escritoras em diferentes tempos e espaços. Estudos que tem contribuído para retirar dos escombros do passado, a condição de apagamento de saberes, práticas educativas, produções escritas que expressam o pensamento educacional de professoras normalistas. Sujeitos do campo educacional situados até então numa condição de apagamento pelo silêncio de

\footnotetext{
${ }^{3}$ Estudos trazidos por MATOS (2013), a partir década de 1980, 1990, e século XXI: Embora inaugurado no Brasil com SAFFIOTI, a partir do Trabalho Feminino (1969), a década de 1980 trouxe as experiências, a vida e as expectativas das mulheres: RAGO (1985), SOIHET(1989), LOPES (1985). Ad décadas seguintes, os estudos assinalam os processos de exclusão e vitimização da mulher, assim como as lutas e as conquistas femininas. SCOTT (1992) inaugura as análise a partir do gênero, como categoria de análise e demais autoras como Catani (1997), Martins (1996), Almeida (1996) Louro (2013), Vidal (2001), Veiga (2011), que subsidiam os estudos sobre a mulher.
} 
mulheres escritoras e suas obras. Mulheres que emerge e testemunham sobre seu tempo, sua trajetória, seu espaço social e suas inserções político-ideológicas que demarcaram um discurso educativo sobre o papel da educação, do magistério feminine, do saber e do ensino escolar primário. São estudos que estão associados às novas configurações do campo historiográfico da história cultural, da história intelectual, da biografia e da história da mulher, voltados então, para a valorização da atuação de mulheres do passado mediante pesquisas que promovam o resgate de "vozes perdidas no passado e (no) reconstruir (de) suas trajetórias através de vestígios que elas deixaram" (LUCENA, 2008, p. 5); mediante empreendimentos investigativos que promovam a reiserção do lugar e do papel desempenhado no seu tempo e espaço social em que atuaram.

A professora Ester Nunes Bibas, sujeito-objeto desta tese alçou um lugar de notoriedade no campo da educação paraense no seu tempo-lugar, ao desempenhar o cargo de professora normalista e de orientadora pedagógica de escolas da Rede pública de Ensino no estado do Pará. O que nos leva a reconhecer que esse lugar de destaque se dá pelo reconhecimento da experiência e de um saber pedagógico, que lhe conferiu uma função técnica de orientação e acompanhamento do fazer pedagógico de professoras em regência de classe. Fato que nos leva a inquirir este lugar, este saber apreendido e ou incorporado por Ester Nunes Bibas ao longo de sua trajetóriaprofissional.

Esse saber revelado pelo pensamento educacional desta escritora é o que pretendemos apreender e compreender a partir da análise dos livros didáticos de sua autoria publicados pela Editora do Brasil S.A entre as décadas de 1950-1960. Uma produção didática que situa a professora Ester Nunes Bibas no patamar de escritora pedagógica, embora se compreenda os percalços trazidos pela história da Mulher, ou de uma mulher, pois ao centralizar o processo de investigação na escrita feminina direcionada para o campo da educação, nos deparamos com as dificuldades inerentes ao campo da história das mulheres; campo que por muito tempo foi ignorado pela então história tradicional, como afirma Tedeschi (2016).

Se o silêncio apareceu na história como um atributo feminino, que constituía parte do suposto mistério constitutivo da mulher (nessa circunstância histórica), é preciso rever seu lugar e pensar os espaços do silencio no qual as mulheres foram "confinadas", resultado de um poder simbólico que impôs papeis e identidades [...] O controle e a distribuição da palavra escrita (TEDESCHI, 2016, p. 154).

Uma constituição da feminina produzida socialmente sob as amarras dos valores patriarcais e do sentimento misógino que estabeleceram o lugar do silêncio para a mulher. Assim, na realidade sociocultural brasileira e, notadamente paraense, as experiências e as 
proposições para o campo da educação, vivenciadas e produzidas por mulheres não foram referenciadas pela história da educação e com o passar do tempo, o esquecimento e a perda dessa memória histórica tornaram-se as marcas do silencio e da ocultação da atuação feminina.

Tedeschi (2016) enfatiza os processos de esquecimento e ocultação das mulheres pela centralização atribuída a "natureza masculina" e ou ao "androcentrismo" da história, que por muito tempo ocultou a atuação feminina pelo não reconhecimento da produção intelectual das mulheres. Fato problematizado pelos historiadores do campo da história das mulheres e de outras vertentes históricas que problematizam sujeitos esquecidos pela história a exemplo dos autores Perrot (2007), Burke (1992) e Thompson (1965).

No contexto atual a história de professoras primárias localizada no passado encontrase esquecidas e assim imersas num contexto de silenciamento por conta da ausência de registros documentais e somente emergem desse lugar de ocultação pela análise de rastros, vestígios trazidos por fragmentos escritos e por rememorações de familiares e amigos. Assim, o lugarde invisibilidade de professoras se justifica no cenário educacional brasileiro e local pela exclusão da experiência e da intelectualidade de professoras normalista. Assim, todo esse processo de apagamento das experiências de professoras e de escritoras no âmbito da educação brasileira está diretamente vinculado à ocultação da mulher e de outros grupos sociais classificados e posicionados pelos processos de desigualdade e exclusão social, que permearam as representações e o lugar do masculino e do feminino na sociedade brasileira, amazônica e paraense. Sujeitos que ao longo da história mantiveram-se ocultos, subalternos, sem voz e destituídos da condição de sujeitoshistórico.

O Brasil no transitar do século XIX para o século XX, vivenciou um momento de grandes mudanças com a implantação da era republicana, diante dos novos ideários passou a exigir a apropriação da língua nacional e da escrita, compreendidas nesse momento como referências de uma nação autônoma e soberana no âmbito político e intelectual.

Todavia, neste cenário de modernização permaneceram as marcas da exclusão de grande parcela da população e, de forma acentuada, a exclusão da autoria feminina.

A constituição da mulher letrada esteve diretamente associada ao acesso da mulher à educação, à leitura e à escrita num contexto político em que se reconhecia que a educação tornara-se condição precípua para a efetivação da nacionalidade e para o alcance da modernização e do progresso da nação brasileira. Toda essa capacidade criativa do feminino se deu pelo exercício da leitura e da escrita sobre si e sobre o mundo; o que levou a mulher brasileira a exercitar a escrita e a publicar seus textos. Nestes escritos, as mulheres escritoras 
registraram e publicizaram seus pensamentos, suas angústias, seus sonhos, projetos e bandeiras de lutas, como sinalizadores de uma postura rebelde e libertária de algumas mulheres que se contrapunham aos valores e padrões culturais patriarcais, limitadores dos avanços dosujeito-mulher.

No contexto atual a história de professoras primárias localizada no passado encontrase esquecida e assim imersa num contexto de silenciamento por conta da ausência de registros documentais. E somente emergem desse lugar de ocultação pela análise de documentos, fragmentos escritos, rastros, vestígios e por rememorações de familiares e amigos, que possibilitam romper com a invisibilidade, a exclusão das experiências e da intelectualidade de professoras normalistas no cenário educacional brasileiro e local. Assim como, permite a compreensão deste processo de apagamento das experiências e das contribuições de professoras e de escritoras normalistas no âmbito da educação brasileira está diretamente vinculado à ocultação da mulher e de outros grupos sociais classificados e posicionados pelos processos de desigualdade e exclusão social, que permearam as representações e o lugar do masculino e do feminino na sociedade brasileira, amazônica e paraense. Sujeitos que ao longo da história mantiveram-se ocultos, subalternos, sem voz e destituídos da condição de sujeitoshistórico.

O Brasil no transitar do século XIX para o século XX, vivenciou um momento de grandes mudanças com a implantação da era republicana, diante dos novos ideários passou a exigir a apropriação da língua nacional e da escrita, compreendidas nesse momento como referências de uma nação autônoma e soberana no âmbito político e intelectual. Todavia, neste cenário de modernização permaneceram as marcas da exclusão de grande parcela da população e, de forma acentuada, a exclusão da autoria feminina.

A constituição da mulher letrada esteve diretamente associada ao acesso da mulher à educação, à leitura e à escrita num contexto político em que se reconhecia que a educação se tornara condição precípua para a efetivação da nacionalidade e para o alcance da modernização e do progresso da nação brasileira. Toda essa capacidade criativa do feminino se deu pelo exercício da leitura e da escrita sobre si e sobre o mundo; o que levou a mulher brasileira a exercitar a escrita e a publicar seus textos. Nestes escritos, as mulheres escritoras registraram e publicizaram seus pensamentos, suas angústias, seus sonhos, projetos e bandeiras de lutas, como sinalizadores de uma postura rebelde e libertária de algumas mulheres que se contrapunham aos valores e padrões culturais patriarcais, limitadores dos avanços do sujeito-mulher.

A mulher asenhoriando-se de sua intelectualidade passou a produzir textos literários e 
outros escritos relacionados à diferentes áreas do saber. No entanto, toda essa produção cultural feminina se manteve sob os ditames do contexto sociocultural nacional que valorizava e reconhecia a atuação e a intelectualidade masculina, ao mesmo tempo em que impunha limites à participação da mulher pela manutenção das condições de exclusão, de negação do feminino pela desautorização do pensar e do escrever no feminino, vistos como transgressões da mulher diante das normas instituídas pela sociedadepatriarcal.

Parafraseando a autora Norma Telles (1997), a mulher "escreveu e escreveu bastante" num contexto sócio histórico eminentemente centrado no poder masculino, ancorado numa concepção patriarcal, que nega a escrita feminina, situando-a como discurso marginalizado de mulher. Tornando-se urgente um revisionismo para compreender o ser mulher, como escritora, como leitora, enquanto sujeito pensante e, mediante o estudo de suas escritas, o elucidar do olhar, um saber outro distinto do masculino, que reoriente a interpretação da história e romper com uma visão estereotipada da mulher trazida pelos textos notadamente masculinos. Esta autora considera necessário tais interpretações e compreensões que levam à crítica e o revisionismo do pensamento masculino, ainda que esta mulher se encontre localizada num lugar de dependência que lhe atribui sentido e um lugar social, no qual, sua narrativa seja enquadrada como um pensar transgressor e de marginalidade reforçado pela permanência de uma representação feminina marcada pela diferença e pela desigualdade atribuída às características físicas e psicológicas do feminino como diferenças que exaltam a beleza, a subjetividade e o refinamento como padrões normativos. Para Telles (1997) os estudos nesse campo devem situar essa mulher em sua relação com seus pares, em relação a outros sujeitos, e em relação a si mesma para se chegar a uma compreensão com maior proximidade desse sujeitofeminino.

Dito isto, ressaltamos que a presente tese se fundamenta teórico-metodologicamente na História Cultural e estabelece aproximações com as abordagens empreendidas pela História Intelectual, Estudos Biográficos, História da Mulher e suas interconexões com a História da Educação. Elegemos como método de estudo e análise dos livros didáticos Páginas Brasileiras, o estudo sobre a materialidade desses livros com a intenção de apreender a partir das marcas editoriais e organizacionais, os sentidos e a intencionalidade então sinalizados; assim como, a análise discursiva dos gêneros textuais direcionados à leitura, selecionados do Terceiro e do Quinto Livro, localizados da coletânea didática de autoria de Ester Nunes Bibas. A análise discursiva dos livros didáticos se subsidia na perspectiva dialógica bakkhtiniana. São processos que se aliam aos estudos e analyses dos dados documentais e dos relatos testemunhais que referenciam e localizam a trajetória desta 
professora paraense.

A história cultural, sob o enfoque da "história vista de baixo" trouxe para o centro dos estudos históricos, as trajetórias de pessoas comuns e a valorização de sujeitos em sua cotidianidade, considerados sujeitos excluídos da história tradicional. A conformação da Nova História possibilitou a emergência de diferentes vertentes historiográficas, e entre elas, a história da mulher, a história biográfica, intelectual e outras abordagens historiográficas que possibilitaram a percepção da atuação de sujeitos em sua cotidianidade.

A história da mulher no Ocidente a partir da década de $1980^{4}$ se subsidiou pela análise de gênero. O sexo tornou-se a base referencial para a compreensão das relações socioculturais entre o masculino e o feminino e para a percepção da dinâmica dos espaços do privado e público transitados por homens e mulheres. A história da mulher nesse momento assumiu uma postura de embate a prioridade dada à história do homem e a "pseudo" presença da mulher no contexto histórico. Este direcionamento reforçou o propósito de explicitar as relações de poder e domínio sobre mulheres e enfatizar a trajetória e a atuaçãofeminina.

O gênero tornou-se importante categoria de análise nesta nova escrita sobre a mulher, como elemento decifrador das diferenças entre masculino e feminino e aporte para a compreensão da "diferença dentro das diferenças", inscritas nas relações de gênero e para a visibilidade da pluralidade de ser mulher: mulher mãe, esposa, filha, intelectual, professora e escritora pela recusa do discurso universal masculino.

Para Zinani (2006), os estudos sobre o gênero elucidam e proporcionam a percepção do lugar do masculino e do feminino na ordem societária num determinado tempo histórico e lugar. Para o campo investigativo sobre história de mulheres, torna-se element referente para se apreender os processos de construção identitárias, enqunto processos de produção demarcado pelos valores ideológicos, então matizadores da vida social e cultural, como mediadores das tramas sociais, da condução politico-ideológica, que delimita o trânsito dos diferentes grupos sociais, a partir do lugar que cada agrupamento ocupa na sociedade em que faz parte.

O trânsito feminino na sociedade brasileira esteve diretamente associada pela outorga da sociedade, das instituições políticas e religiosas que impuseram prerrogativas à atuação feminina e ao exercício professional controlado e vigiado pelo pai, pelo esposo, pelos irmãos, pela igreja, pela escola, pelo estado, representantes da cultura patriarcal.

Nesse controle, a filha, a aluna, a esposa, a professora, que deveriam trilhar pelos

\footnotetext{
${ }^{4}$ Estudos e Pesquisas empreendidas por PERROT (1980), SCOTT (1990).
} 
caminhos instituídos, para que não se afastassem do lugar social delimitado e assim não se afastassem o ideal de mulher a ser buscado, desempenhado e acima de tudo preservado. Em se tratando de professor, como profissão do possível, aceitável, referendado, desde que não alterasse as prerrogativas de ser mulher, Segundo dos ideários pensados e defendidos para mulher brasileira e paraense.

A professora Ester Nunes Bibas se localiza num tempo-lugar em que a sociedade e a própria historiografia não reconhecia as mulheres como sujeitos históricos e nesse condicionamento, as mulheres se viram vedadas a terem suas histórias, seus escritos e sua intelectualidade valorizada. Ainda assim, nessa temporalidade, as mulheres buscaram a formação escolar e muitas delas tornaram-se professoras normalistas e entre estas, algumas se tornaram escritoras de livros voltados para o campo educacional ou para a escrita literária. $\mathrm{O}$ que nos leva a apreender que o magistério, a princípio se tornou um lugar de excepcionalidade profissional, considerando-se os valores patriarcais que reforçavam o lugar e o domínio do masculino nas atividades sociais, econômicas, políticas e no campo da intelectualidade. Entretanto, a partir desse lugar do "possível” algumas mulheres exerceram seu direito á voz e ao reconhecimento de suas escrituras.

O professor Clóvis Meira (1988), publicou no jornal local “O Liberal” em 05/06/1988, uma homenagem à "Mestra Ester Nunes Bibas", em data comemorativa ao centenário de nascimento desta professora. Meira (1988) em seu discurso traz a tona informações sobre a maneira de ser e de ensinar desta professora. Nesta homenagem relata sobre as premiações recebidas por Ester Nunes Bibas e faz referências obre a importância dos livros didáticos "Páginas Brasileiras", que tiveram uma circulação significativa nos grupos escolares de Belém e municípios do estado do Pará, chegando a 08 (oito) edições pela Editora do Brasil S.A.

Relatos que demonstram uma contínua demanda em torno desses livros didáticos e um contínuo processo de reedições da obra, possibilitou a circularidade de ideias, pensamentos didático-pedagógicos na rede educacional local. Se tornando uma produção didática conhecida, trabalhada, estudada e que alcançou uma geração de professores e alunos das escolas paraenses.

$\mathrm{Na}$ pesquisa de fontes e registros sobre a trajetória e os caminhos percorridos por Ester Nunes Bibas, localizamos fragmentos escritos que enfatizam sua produção poética, embora façam referências a produção didática desta professora. A coletânea: Introdução à Literatura do Pará (1990), em seu quarto volume, traz registros pontuais a respeito da história desta educadora paraense e faz um breve relato sobre os livros didáticos Páginas Brasileiras. No 
livro de poesias Rimas do Coração (1958), Ester Nunes Bibas traz poemas autobiográficos, como exemplo o poema "EU", em que a autora escreve momentos vividos em sua cidade natal, Vigia-Pa, e aponta os principais acntecimentos de sua vida como mãe, professor e seu potencial para a escrita. Nesse processo de coleta de fontes, dados, rastros, relatos de familiares e escritos, ainda que, fragmentários, sinalizam a maneira de ser e da atuação desta professora paraense. Utilizamos a técnica da entrevista junto aos netos desta professora, Vânia Bibas Rio e Jaime Bibas, que na infância conviveram com Ester Nunes Bibas. São rememorações de fatos, eventos e situações trazidos pelas lembranças do convívio familiar, que muito dizem e sinalizam a trajetória desta educadora. Nesse percurso investigative, a coletânea didática "Páginas Brasileiras", tornou-se objeto de estudo material e discursivo para a identificação e compreensão do pensamento educacional da professora Ester Nunes Bibas. Como produto cultural, assumiu lugar destacado nesta produção acadêmica com vista à apreensão do pensamento educacional, intelectual, as condições histórico-ideológicas e seus sentidos enunciados pela autora.

Chartier (1998) caracteriza o livro como um produto cultural e ressalta as ingerências do cenário cultural no processo de produção de um livro. Resultando num produtoque sinaliza e é sinalizado por um conjunto de condicionamentos (socioculturais) que derivam das formas particulares, nas quais o texto é posto diante do olhar. Uma produção textual, um discurso que transmite competências, convenções, códigos próprios à comunidade a qual pertence cada leitor e como escrita produzida revela o escritor e o contexto social, no qual está inserido, tornando-se para a prática educativa o meio estratégico para o exercício subjetivo do aprender. As práticas da leitura e da escrita se revestem das percepções do mundo social trazidas pelo escritor, ao considerar-se que os textos escritos não se constituem "discursos neutros", produzem estratégias, sinalizam práticas sociais e políticas escolares como expressão do pensamento dos valores e da cultura de quem escreve, revelando-se assim, como uma prática cultural, que emite sentidos e significados enunciados pelo escritor e recepcionados pelosleitores.

Como escritora Ester Nunes Bibas se reveste da condição de sujeito da cultura, agente produtor de cultura, na medida em que seus livros com fortes influências regionalistas revelam o cenário sociocultural em que foi produzido, além de imprimirem experiências de convívio social, de aprendizagem e de saberes que normatizavam a convivência com outros sujeitos envoltos na prática escolar. O mundo escolar torna o professor e o aluno aprendizes de si mesmos, dos outros e do mundo em que vive numa relação dialógica, que transforma os participantes do processo educativo em sujeitos de ação que pensam e se posicionam nesse 
processo diante do cenário escolar, das vivências de saberes, das normas de condutas socais, da valorização das práticas educativas, da educação, da escola, da cultura e do própriosaber.

Os livros da professora Ester Nunes Bibas estão situados no campo da leitura, da escrita, do ensino de disciplinas escolares, das práticas docentes e no empenho pelo escrever no campo do ensino-aprendizagem, o que confere a esta educadora o lugar e o papel de intelectual do campo da educação.

Para Barthes (1975), o professor se reveste de intelectualidade no momento que escreve e publica um livro, uma proposição, que lhe assegura a autoria de uma produção textual. Por sua vez, o texto escrito é endereçado à leitura e a escrita e situam osdiferentessujeitos interlocutores presentes nos discursos enunciados; sujeitos que falam ou apresentam-se silenciados na cena da comunicação. E ainda que sob o condicionamento do silêncio, a relação entre sujeitos revela a vida e o contexto sociocultural em que estão inseridos os diferentes sujeitos. Nesse campo de linguagem e da comunicação, a relação entre sujeitos é gestada tanto pela imposição quanto pela contraposição diante de saberes escolares normativos e valorativos da culturadominante.

O lugar da mulher, da professora e da escritora brasileira esteve diretamente associado à constituição da mulher, cujo papel social foi determinado por múltiplas determinações políticas, sociais e culturais e, que ao longo do tempo, se tornaram fatores decisivos para a construção de uma representação de mulher.

No Brasil, a constituição da mulher e seu papel social estiveram relacionados às múltiplas determinações políticas, sociais e culturais que ao longo do tempo tornaram-se fatores decisivos para a construção de uma representação de mulher permeada por similitudes, peculiaridades e diferença. A organização da sociedade brasileira marcada pela presença oligárquica e aristocratização de grupos que reconhecidamente exerceram o domínio e o poder para ditar normas disciplinadoras que subalternizaram os demais grupos sociais, o que estabeleceu a naturalização do controle e subjugação de mulheres, crianças, parentelas, agregados e todos os demais grupos situados na relação de dependência do grupo majoritário, revelando-se nessa realidade, a marginalização e a ocultação de sujeitos sem voz e sem reconhecimento social.

Neste contexto de desigualdade, as atividades femininas se mantiveram circunscritas no âmbito do privado e no espaço doméstico, e neste espaço restrito, a atuação da mulher se voltava para a educação dos filhos, aos cuidados com o esposo e com a casa, ações vistas como necessárias para a solidificação familiar. A mulher era inserida nessa ordem social, como ajudante do homem, como educadora dos filhos, enfim, como "um ser de virtude", "um 
anjo" do lar, uma vez que, a família estava sob o comando do pai, do marido e do homem que exercia poder e domínio sobre seus dependentes eagregados.

Ester Nunes Bibas é contemporânea de um cenário brasileiro marcado por mudanças de toda ordem. Politicamente, o país estava passando pela transição do Império para a implantação e consolidação do Estado Republicano. Um momento histórico demarcado por transformações políticas, econômicas, sociais, culturais e educacionais, subsidiadas pelos ideários de progresso e de modernização do país, buscados com vista a inserção no mercado capitalista, ao processo de industrialização. A mudança de mentalidade do cidadão republicano deveria se dar pela incorporava novos modelos produtivos, novas relações no mundo do trabalho e uma formação educacional, que possibilitasse uma qualificação do povo brasileiro para o alcance dos patamares da civilidade e dacivilização.

Neste cenário, a professora Ester Nunes Bibas consolida sua formação de mulher letrada, tornando-se professora normalista em 1907, momento áureo da produção da borracha na Amazônia brasileira. Belém, neste momento, estava movida por transformações socioeconômicas trazidas pela "era da borracha" e vivenciava os ares e os costumes parisienses considerados exemplos civilizatórios e de civilização. No entanto a inserção da mulher paraense no contexto de modernização não ocorreu, pois, mesmo diante do clima de progresso, aqui observado, não se alteraram as bases conservadoras que sustentavam os padrões culturais amazônicos. Permanecia no estado do Pará e na região amazônica o controle e o poder de mando das elites locais, que cerceavam a participação da mulher no espaço público.

A trajetória histórica desta professora como mulher e profissional se dá em meio ao cenário belenense, marcado por uma cultura conservadora, elitista, aristocrática e excludente. Neste espaço social, a professora Ester Nunes Bibas rompe com alguns paradigmas e amarras que limitavam a atuação da mulher paraense, pois, ainda que o espaço privado da família, o resguardo do papel de esposa e mãe dedicada continuasse como lugar social e papeis a serem desempenhados pelo feminino, esta professora alcançou visibilidade no espaço público a partir do exercício do magistério. E nesse transitar entre o espaço privado e o público alçou voo ao se destacar na docência, na poesia e na produção de livros didáticos no âmbito da educação. A professora Ester Nunes Bibas na década de 1930 é referendada pela Sociedade Beneficente Literária Cinco de Agosto (Vigia-1939), como professora atuante, intelectual e reconhecida poetisa. Segundo Meira (1988), momento em que seus escritos são publicadas em jornais e revistas locais. Desta forma, todo seu engajamento literário, político e educacional revestiu Ester Nunes Bibas para uma atuação efetiva no campo da escrita e nesse 
protagonismo, a produção da coletânea didática "Páginas Brasileiras" e "Rimas do Coração" no campo dapoesia.

Dito isto, a tese apresenta cinco capítulos estruturados, a partir das preocupações e objetivos mencionados ao longo do texto, os quais serão descritos e situados nos parágrafos seguintes.

O primeiro capítulo desta tese intitulado "O Lugar dos Novos Sujeitos da Educação" é organizado como uma reflexão teórica a respeito da condição feminina e a inserção da mulher no campo da educação, como profissão do "possível" reconhecida inicialmente como campo de exercício profissional do feminino e, que a partir dessa inserção no mundo do trabalho, algumas mulheres professoras alçaram outros caminhos pelo espaço público. Inicialmente o capítulo estabelece uma aproximação entre a educação e o campo historiográfico, assinalando a abertura das fronteiras investigativas no campo da educação. A reflexão sobre a representação do "ser feminino" e do "ser professora" pauta-se nas contribuições de: Perrot (2007); Saffiot (2014); Del Prior i(2012); Almeida (1998); Venâncio (2008); Miguel (2014);

Souza (2011); Cardoso (2011); Vidal (2001); Carvalho (2001); entre outras autoras, que associados aos parâmetros da história cultural, da Mulher e da história da educação, trazem interpretações sobre a conjuntura histórica, social, cultural, educacional e ideológica produtoras dos processos de invisibilidade da mulher, ao ser localizado num lugar do silêncio. No campo da educação primária, as mulheres professoras e escritoras, tornaram-se os novos sujeitos do campo educacional, em meio aos processos de vigilância acerca da atuação da mulher no campo da educação. Pois, o magistério, o lugar do possível tornou-se para algumas professoras, o "lugar" de possibilidades para além da abnegação esperada.

O segundo capítulo "Transitando pelos Caminhos da História cultural: Aporte teóricometodológico" está organizado, a partir das contribuições trazidas por autores do campo da história cultural, história da mulher, história intelectual, história biográfica e história da educação como caminhos teórico-metodológicos para os processos de investigação, estudo, análise e interpretação do sujeito-objeto desta tese, a professora escritora Ester Nunes Bibas e sua obra didática "Páginas Brasileiras" com vistas a apreensão e compreensão do pensamento educacional desta educadora a partir dos discursos enunciados em seus livros didáticos. Este capítulo subsidiará a produção dos capítulos seguintes.

O terceiro capítulo “Trajetória da Professora Ester Nunes Bibas" pauta-se em informações "fragmentadas" em documentos, livros, jornais e relatos de parentes desta professora, que sinalizam rastros e vestígios indiciários dos caminhos percorridos por Ester Nunes Bibas. O capítulo traz intenção de conhecer a mulher, a educadora e a escritora, na 
compreensão da incompletude desta educadora paraense pela ocultação e pelo silencio em que se encontra a autora e sua obra.

O quarto capítulo trata da “Análise Material do Livro Didático "Páginas Brasileiras” e registra o estudo sobre a materialidade apresentada pelos exemplares localizados, integrantes da coletânea de autoria de Ester Nunes Bibas. O capítulo sinaliza as apreensões a respeito da

intencionalidade enunciada e ou declarada pelos livros, a partir dos elementos materiais, editorias e imagéticos inscritos nos livros; assim como, elementos que indicam recortes temporais, histórico-educacionais e relacionados aos protocolos editoriais. O capítulo compreende a materialidade do livro como indicador de um conteúdo histórico-ideológico.

O quinto capítulo aborda "O Pensamento Educacional de Ester Nunes Bibas: Entre Discursos e Interdiscursos" retrata o processo de análise baseado em procedimentos teóricometodológicos que perpassam pelas reflexões trazidas pela história cultural, pela história da educação e pelas contribuições da perspectiva bakhtiniana, como suporte aos processos de análise discursiva dos livros didáticos "Páginas Brasileiras", focalizada no estudo do Terceiro e do Quinto Livro desta autora, então localizados. O capítulo registra as apreensões dos sentidos direcionados pelos gêneros textuais selecionados, das concepções de educação, de escola, do saber escolar e o contexto histórico-ideológico apontado pela obra; os sujeitos envoltos no processo de formação escolar e o lugar social e epistêmico, no qual, Ester Nunes Bibas se associa, fala e escreve sua obra didático-pedagógica.

A importância desse estudo se dá pelo resgate da trajetória histórica e do pensamento educacional de mulheres, ao trazer do passado, do recôndito do mundo feminino, saberes, práticas educativas, discursos e escritos, como expressão da intelectualidade feminina. Focaliza-se nesse estudo, a autora Ester Nunes Bibas e seus escritos voltados para a área de educação e com esse propósito, resgatar-se-á o pensamento feminino na área da educação e o papel protagonista de uma mulher normalista e intelectual do campo educacional. A análise e a compreensão desta produção cultural ganha importância precípua para o entendimento das ingerências do cenário cultural no processo de produção desta produção intelectual, assim como perceber o que seus escritos revelam, sinalizam e são sinalizados pelo conjunto de condicionamentos socioculturais reveladores das particularidades regionais, locais e das competências, convenções, códigos próprios da comunidade que atribuem o sentido de pertencimento do leitor. Diante dessas imbricações, o livro se reveste como meio estratégico para o exercício subjetivo do aprender e meio revelador de quem escreve; o autor em seu contexto social, seu tempo histórico, suas ideias e ideologias. Dessa forma, a leitura e a escrita oportunizada pelo livro escolar aos leitores estarão permeadas pelas percepções do mundo 
social trazidas pelo escritor. Considerando-se que os escritos não se constituem "discursos neutros" e nem "descarnados, ao produzir direcionamentos que sinalizam práticas sociais, políticas e sabers escolares como expresses do pensamento dos valores, da cultura do(a)autor(a). Revelando-se então, como uma prática cultural, que emite sentidos e significados enunciados pelo escritor e recepcionados por seus leitores.

Ao privilegiar o exercício do escrever vivenciado por Ester Nunes Bibas, o presente estudo se associa ao protagonismo de professoras normalistas escritoras que enfrentaram os desafios do magistério e venceram as normas disciplinadoras do lugar da mulher, professora e do exercício intelectual feminino. Mulheres que na posição de professoras primárias, se apropriaram de saberes e se constituíram em mulheres "empoderadas" que exercitaram o direito à voz e o reconhecimento de suas escritas. Mulheres que conseguiram ir além do circuito do lar e da sala de aula, reconhecidas como lugares essencialmente femininos. Nesse avançar das fronteiras do privado, do ofício docente para diferentes atuações, como por exemplo, a produção literária, a produção de livros, cartilhas, escritos publicados em jornais e revistas de sua época. Um novo fazer feminino que demarcou novos espaços sociais, em que as mulheres passaram a circular, dando visibilidade a seus pensamentos, a suas práticas, e a suas produções intelectuais. O que fez emergir uma nova representação feminina, a mulher letrada, mulher intelectual, que socializa experiências, conhecimentos construídos ao longo de sua formação e no decorrer de suas vivências no campo da educação.

A tese, a partir de uma abordagem interdisciplinar proporcionada pelo intercruzamento dos campos da história cultural, da linguagem e suas interfaces com o campo da educação, traz o empenho teórico-metodológica de romper com a "obscuridade" da vida e da obra de Ester Nunes Bibas, e assim, promover a visibilidade do pensamento educacional desta professora e escritora, enquanto registro acadêmico e fonte documental material para a (re)inserção desta educadora paraense como sujeito histórico no campo da história da educação do Pará. Assim sendo, a tese, enquanto escrita acadêmica, inaugura o estudo acerca de professoras normalistas, escritoras de obras para a educação no estado do Pará e abre caminhos para que outros estudos sobre a vida e a intelectualidade de professoras paraenses, a exemplo de Ester Nunes Bibas, outras professoras rememoradas e ou referendadas na atualidade por nomes de escolas públicas da rede de Ensino do Estado e do Município de Belém, como referências indiciárias da importância e reconhecimento de suas contribuições para o campo da educação local. São mulheres, professoras e escritoras que em suas trajetórias, tornaram-se sujeitos protagonistas no campo da educação ou em outros campos do saber. 


\section{O LUGAR DOS NOVOS SUJEITOS NO CAMPO HISTORIOGRÁFICO: Mulheres,} Professoras, Escritoras

Os estudos empreendidos pela história da educação associados às diferentes matizes da Nova História ao longo das últimas décadas vem provocando inflexões sobre as abordagens teóricas e metodológicas no campo de pesquisa da educação, na medida em que, essa associação vem possibilitando o transitar da história da educação pelas diferentes vertentes do campohistoriográfico.

Neste intercruzamento pelos caminhos da história social e da história cultural vem se observando no campo da história da educação a incorporação de uma diversidade de objetos, temas, sujeitos e problemas até então não priorizados pelos estudos empreendidos pela história da educação. Assim, sob a perspectiva da Nova História Cultural, a escrita historiográfica da História e da História da Educação passou a ser direcionada para a produção escrita das "representações" do social; ou seja, para a "escrita do real" e de sujeitos concretos pela valorização das experiências vivenciadas por grupos e indivíduos, a partir da apreensão de suas trajetórias pessoais, profissionais e em suas inserções no mundo sociocultural, como focos reveladores do modo de viver, sentir, pensar e produzir, numa perspectiva de sujeitos produtoresculturais.

Nóvoa (2013) e Tardif (2014) em estudos direcionados para o campo educacional, especialmente relacionado aos saberes docentes, a formação profissional e as práticas de professores, tratam das contribuições intelectuais de professores para o campo da educação escolar.

\footnotetext{
Nóvoa (2013) focaliza seus estudos na história de vida dos professores e "evoca" para esses estudos de caráter biográfico, "as dimensões pessoais e profissionais [...] A ação e o saber dos professores". Como dimensões inerentes da atuação pedagógica desses sujeitos do campo escolar, "ignorados, parecendo não terem existência própria enquanto fator determinante da dinâmica educativa (embora), cada um continuou a produzir no mais íntimo de sua maneira de ser professor" (NÓVOA, 2013, p. 15).
}

Tardif (2014) em seu estudo Saberes Docentes e Formação Profissional traz a tona a problematização a respeito do "papel e do peso dos saberes dos professores em relação a outros conhecimentos que marcam a atividade educativa e o mundo escolar" (TARDIF, 2014, p.9). Sem descartar todos os conhecimentos incorporados ao longo da vida profissional.

São estudos que recuperam o pensamento e as práticas docentes e ampliam as fronteiras para pesquisas investigativas. Os estudos de Giroux (1997) afirmam que o "professor" como 
intelectual nas últimas décadas se tornou um novo sujeito-objeto de investigação do campo da educação e, nessa percepção, emergem no Brasil pesquisas acadêmicas focalizadas na história e nas contribuições dos docentes para o campo da educação escolar.

Nesse campo, embora ainda rarefeito, vem emergindo a partir de grupos de pesquisas ligadas a Programas de Pós-Graduação ${ }^{5}$, pesquisas e estudos voltados para a história e as contribuições do magistério primário, especialmente, a docência feminina. Uma temática que tem mobilizado os pesquisadores desse campo para a efetivação de estudos relacionados à valorização da atuação da professora normalista, os saberes docentes, a formação profissional e os saberes construídos na cotidianidade da prática da docência. Outra dimensão desses estudos vem se encaminhando para a compreensão das contribuições intelectuais de professoras primárias inscritas na produção e publicação de livros didáticos entre outros temas e objetos de estudos que focalizam o lócus escolar, a educação, o saber escolar como direções investigativas que tem potencializado o campo da história da educação.

Nessa direção dos estudos no âmbito da educação, as professoras primárias escritoras ganham o estatuto de novos sujeitos neste campo historiográfico, seja pela valorização da atuação profissional dessas professoras, seja pelo reconhecimento da intelectualidade e da produção de orientações, cartilhas e livros escolares para o ensino primário.

\subsection{A EDUCAÇÃO E O CAMPO HISTORIOGRÁFICO: EMBATES E POSSIBILIDADES}

O campo da História da Educação e ou da História da Pedagogia, Cambi (1999), surgiu entre os séculos XVIII e XIX e, expandiu-se no século seguinte. Nesta fase de constituição, a história da educação se caracterizou como campo específico de pesquisas efetivadas por pessoas ligadas ao campo da educação e da escola.

Os interesses dessas investigações neste momento se voltavam para o processo de organização da educação e da instituição escolar sob o foco da modernização da sociedade.

Os textos e os discursos eram marcados pelo ideal da civilização e da civilidade, como marcas da identidade do sujeitomoderno.

Após o período das Grandes Guerras e diante da reorganização econômica internacional, observa-se a emergência de mudanças de toda ordem. Neste momento de reordenação, o campo historiográfico passou a buscar reorientações que levaram a revisão da escrita histórica, o que provocou inflexões na produção de todas as áreas do saber e em

\footnotetext{
${ }^{5}$ Estudos sobre o tema localizados em Programas de Pós-Gradução: USP, UERJ, UESB, UFMA, UFSC, UFPA.
} 
especial, no campo pedagógico.

Cambi (1999) assinala que o campo da pedagogia no momento em que seus paradigmas "entravam em crise alguns pressupostos daquele modo tradicional de fazer história da pedagogia, iniciava-se um longo processo que levou a substituição da história da pedagogia pela a mais rica, complexa e articulada história da educação" (CAMBI, 1999, p. 29). E nessa nova história da educação (que) emerge entrelaçada pelos campos historiográficos, e mediante um processo de interação com outros saberes, o campo da educação foi se apropriando de aportes de diferentes vertentes do campo historiográfico num contínuo processo deintercruzamento:

A história da educação é hoje, um repertório de muitas histórias, dialeticamente interligadas, e interagentes, reunidas pelo objeto complexo "educação", embora colocadas sob óticas diversas e diferenciadas na sua fenomenologia. Não só; também os métodos (as óticas, por assim dizer) tem características preliminarmente diferenciadas, de maneira a dar a cada âmbito de investigação a sua autonomia/especificidade, a reconhecê-la como um "território" da investigação histórica (CAMBI, 1999, p. 29).

\footnotetext{
Nesta citação observa-se a emergência de um novo cenário marcado por um processo de renovação e ampliação do campo investigativo da educação, na medida em que, as pesquisas nesta área estabelecem novos objetos, a partir de estudos subsidiados por aportes teóricos e metodológicos relacionados à História e a outras Ciências Sociais, como novos subsídios para a história da educação, que lhe proporcionou outro fazer investigativo pautado em uma nova escrita histórica.
}

$\mathrm{O}$ artigo intitulado, "O (não) lugar da História da Educação na História”, de autoria das professoras Maria Neide Sobral da Silva e Marlucia Menezes Paiva, apresentado no VI Congresso Luso-Brasileiro, Uberlândia- MG, 2006, estabelece algumas aproximações e ao mesmo tempo problematiza o lugar da História da Educação no campo historiográfico. Estas professoras em suas investigações não localizaram no campo da História temas ou objetos específicos ou referentes à história da educação. As autoras consideram esse fato como "ausência, negação, marginalização" ou simplesmente o silenciamento dos historiadores de ofícioemrelaçãoatemasouobjetosdocampodaeducaçãoeindagamoslimitesdahistória da educação no campo historiográfico e ou sua suposta pertença a este campo. embora reconheçam que o "campo educacional vem estabelecendo proximidades e diálogos com diferentes vertentes historiográficas nas últimas décadas" (SILVA, 2006. p.p. 1694,1695).

Barros (1999), com relação às aproximações da educação com o campo historiográfico, faz algumas observações, a partir de análises sobre as fronteiras do campo historiográfico e as 
aproximações da História com a História da Educação. Para este professor, é notório que, o campo da educação vem empreendendo estudos de objetos que se localizam no domínio da História Cultural, e a educação ao inserir nesse circuito investigativo sujeitos, práticas educativas e produções culturais, que passaram a ser situados, analisados e compreendidos como objetos culturais. Para o autor, esta aproximação vem promovendo a interconexão do campo da educação com o campo historiográfico (PAIVA, 2006, p.1695,1696 apud BARROS, 1999, p. 15).

Todo esse processo de cruzamento entre vertentes historiográficas vem se ampliando pelo esforço investigativo de professores-educadores no campo dos estudos culturais e com isso, observa-se a dilatação das fronteiras da história da educação, pela adoção de novos sujeitos, novos saberes e práticas educativas entre outros objetos, que passaram a ser analisados a partir da abordagem da Nova História Cultural. A partir desse contexto historiográfico, os estudos, as pesquisas e a compreensão dos sujeitos-objetos trabalhados pela história da educação ganharam abrangência pela mediação dos olhares historiográficos diversos e ampliados, o que promoveu o alargamento das fronteiras do campo investigativo da educação, diante da limitada produção dos historiadores de ofício no campo da educação.

O cruzamento dos campos da Educação e da História vem se estreitando e possibilitando a percepção do lugar da educação no corpus da historiografia e nessa direção, a concepção de História trazida por Certeau (1999) é bem esclarecedora em relação à compreensão da dimensão social da história e sua interpenetração em diferentes campos do saber. Para o autor, o papel social da história se expressa na produção de uma escrita "singular" de sujeitos questionadores, que se materializa no ato da escrita, ou seja, na produção da narrativa histórica. Assim, o fazer histórico está diretamente interligado a diferentes espaços, lugares, meio social, e sujeitos produtores de conhecimentos multidisciplinares; havendo a interconexão com as áreas do social, político, econômico, da educação e de outros campos que se revelam nesse intercruzamento de saberes.

Nessa relação de cruzamento historiográfico, tem-se observado no âmbito da História da Educação, abordagens mais ampliadas no processo investigativo sobre a realidade educacional, as quais estão diretamente relacionadas ao reconhecimento do lugar social das instituições educacionais, das inflexões da atuação intelectual dos educadores, das memórias das práticas educativas, como também, dos estudos sobre a cultura material pela produção de textos escritos, dos livros escolares e outros artefatos culturais produzidos por educadores.

A instituição da Nova História Cultural desde os Annales (1929) e pelas contribuições de Le Goff (2001), Chartier (1992) e Burke (1992), observou-se significativas mudanças no 
campo historiográfico, ao focalizar como objeto central desta Nova História, a valorização da atuação humana. Adotando-se o enfoque interdisciplinar para as diferentes vertentes ou abordagens, inclusive para o campo da História da Educação.Assim, nesse transitar pela Nova História Cultural, a História da Educação ganhou vitalidade subsidiada pela adoção de novas abordagens e métodos da pesquisa histórica. O processo de interligação entre os diferentes campos historiográficos promoveu a diversificação de temas, objetos e a produção de uma nova escrita da história da educação. Ainda que, nessa relação de aproximação, promova também preocupações e contraposições no campo da História da Educação.

O professor Saviani (2000) com grande produção na área da História da educação brasileira, tem se mostrado apreensivo a respeito da aproximação entre a História da Educação e a História Cultural, embora reconheça que este intercruzamento teóricometodológico entre tais campos tenha trazido inovações para os estudos no circuito da História da Educação.

Embates teóricos sobre a nova configuração, as novas redefinições, as novas temáticas conceituais e metodológicas presentes na historiografia educacional brasileira nos últimos anos e que de certa forma, se contrapõem aos métodos de pesquisa ligada ao viés marxista de análise histórica. A preocupação de algumas teóricos da História da Educação, é com a secundarização e especificidade de seu objeto [...] pois fica evidenciado, na adesão rápida e sem maiores considerações críticas dos historiadores da educação, às linhas de investigação que se tornaram hegemônicas no campo da historiografia (SAVIANI, 2005, p.24).

O professor Saviani emite sua preocupação com essa relação de proximidade e de intercruzamento por conta das novas abordagens trazidas pelo campo da história, distanciadas de sobre maneira, como ele afirma do "viés marxista", até então suporte para as análises no campo da educação. Posições partilhadas e compartilhadas por outros educadores e escritores do campo da história da educação.

No entanto, neste mesmo campo, autores como Lopes (1980), Vidal (2003), Farias Filho (2009) e Castanho (2010), se posicionam diferentemente de Saviani (2000) e defendem a aproximação e a interseção entre a história cultural e a história da educação, por reconhecerem que a associação às diferentes vertentes historiográficos trouxe avanços significativos para a renovação do campo da educação por dialogar com diferentes saberes de diferentes disciplinas. Além do campo da história, contemplam a aproximação com a sociologia, antropologia, literatura, linguística entre outros campos disciplinares que amplia as fronteiras epistêmicas da história da educação.

Para Ângela Maria Martins (2006), a aproximação da educação pelo viés da História 
tem possibilitado embasamentos teóricos e metodológicos para o estudo, compreensão e apropriação dos novos sujeitos-objetos que passaram a ser compreendidos sob os aportes epistêmicos da Nova História Cultural. A aproximação com diversos campos historiográficos promoveu a renovação, a ampliação das fronteiras da História da Educação e possibilitou o acesso a novos embasamentos no âmbito da cultura para compreensão dos processos educativos, do fazer pedagógico e dos sujeitos na produção e apropriação do saber escolar como afirma Santos (2012, p. 7 apud MARTINS, 2006, p. 118) e dessa forma, observando-se a dinamização e ampliação desde campo com relação os objetos e abordagens.

\subsection{MULHERES, PROFESSORAS E ESCRITORAS: NOVOS SUJEITOS DO CAMPO EDUCACIONAL}

\subsubsection{Mulher, Educação e a Voz do Silêncio}

Nas sociedades ocidentais modernas a construção das representações da mulher e seu papel social, estiveram relacionados às múltiplas determinações políticas, sociais e culturais promovidas pela industrialização e pela valorização da educação nesta realidade social. Tais sociedades neste contexto contraditório e desigual promoveram a representação da mulher pelo poder de grupos aristocráticos que subalternizaram o transitar e o saberfeminino.

As mulheres nessa realidade de exclusão se viram prisioneiras no território privativo do lar e da família. Territórios outorgados como lugares do feminino por excelência por serem reconhecidos como espaços apropriados para o desempenho de atividades domésticas. Um lugar social do feminino, mas que insere a mulher de forma "precária e herdeira de um presente sem passado, de um passado decomposto, disperse.

Neste cenário do privado e do privativo em que se materializou e se consolidou a subjugação feminina e, por conta deste condicionamento, por muito tempo as histórias, os acontecimentos e as atuações diferenciadas de muitas mulheres se mantiveram enclausuradas. Uma realidade trazida à tona somente pelo movimento feminista. No sentido de que, o feminismo trouxe outro olhar sobre o espaço público e o espaço privado, e a partir dessa ótica possibilitou a compreensão a respeito da relação de interdependência desses espaços e integrantes de uma construção social única, tornando-se impossível desvincular as relações imbricadas entre esses espaços sociais pela impossibilidade de separar as articulações do privado do espaço público.

Deslocar a esfera política da vida social, a vida pública da vida privada, quando se tem 
como objetivo a construção de uma sociedade democrática. Faz sentido, assim, abandonar a visão de que a esfera privada e a esfera pública correspondem a lugares e tempos distintos na vida dos indivíduos (MIGUEL, 2014, p. 23).

No Brasil, a condição da mulher e sua inserção numa realidade do capitalismo tardio, está diretamente relacionado à questão do sexo como fonte de inferioridade social da mulher. Para Saffioti (2013), a apreensão social do fator natural, o sexo, atua como fator dominante em nossa sociedade na produção do papel social de homens emulheres.

\begin{abstract}
O homem desempenhou e ainda desempenha, portanto, papel relevante na dupla determinação de que é alvo a mulher, enquanto membro de uma classe e enquanto pertencente a uma categoria de sexo. Se ele é duplamente determinado. A consciência do homem é duplamente contraditória na medida em que justifica e auxilia a promover a exploração da mulher na estrutura de classe em virtude de seu sexo, se reforça sua própria determinação, enquanto membro de uma totalidade parcial oposta a outra e oculta essa determinação de si próprio na manutenção de estruturas parciais em que reina como soberano (SAFFIOTI, 2013, p. 77).
\end{abstract}

Esta autora pioneira nos estudos sobre mulheres no Brasil reconhece o sexo como categoria de ordem natural, embora também situe esta questão como fator de encobrimento do antagonismo entre classes, pois, esta categoria natural perpassa de forma transversal pela estrutura de classe, ao trazer à tona as contradições de gênero e de raça e todo esse processo de exclusão social da mulher, contradições que contribuem para legitimar o poderio masculino:

Perrot (2007) é uma historiadora pioneira e engajada com a História da Mulher. Em seus estudos, concebe a mulher como objeto de discurso e sujeito de saber. Como militante feminista, afirma que a mulher tem uma história particular e singular, da qual é sujeito

Os escritos dessa autora se voltam para dar visibilidades de mulheres em seus embates, em suas conquistas e no exercício de poder tanto no campo privado quanto no espaço público. Perrot (2007) focaliza seus estudos na compreensão da condição da mulher francesa do século XIX para dar conta da produção do silêncio e da invisibilidade da mulher na História. Neste sentido, suas pesquisas se pautam na representação de mulheres a partir de uma dimensão ampla e plural, valorizando os contextos sociais, culturais, étnicas e políticos como formuladores da condiçãofeminina.

Perrot (2007) com o propósito de retomar a voz das mulheres francesas, dinamizou e fundamentou o campo da História das Mulheres, subsidiando seus estudos em referências e rastros das mulheres em meio aos acontecimentos do cotidiano feminino do século XIX, e assim, institui um novo caminho metodológico, ao se apoiar em fatos registrados em 
documentos particulares, privados, escondidos e percebidos como subterfúgios de uma história invisível, portanto, não oficial. Referências documentais que passaram a ser considerados como fundamentais para revelar os traços privados de mulheres, formas de resistências, desabafos e indagações transcritos em cartas, diários, enquanto arquivos íntimos, silenciados e silenciadores de um cotidiano de mulheres marcadas pela disciplina e pelo controle social que lhes desautorizou a escrever sobre seus pensamentos e sentimentos em relação ao mundo vivido e em relação aos outros sujeitos, consigo mesma e de maneira subjetiva sobre a ausência de direitos e sobre os processos de vitimização da mulher.

Sob o olhar desta vertente historiográfica, as mulheres que, ao romper com o silêncio do falar, do ler e do escrever passaram a enfrentar embates, oposições, calúnias, por serem vistas como transgressoras das normas, dos costumes e das limitações impostas às mulheres pela sociedade vigente.

Esta abordagem sobre a história de mulheres se associa às contribuições de Raymond Williams (1958) trazidas para o campo dos estudos culturais, por meio de uma concepção de cultura relacionada à experiência do dia a dia e na atuação dos sujeitos na cotidianidade, em que atribuem significados a uma dada sociedade. Nessa experiência da ação humana o reveler da maneira de ser, de viver e de todo o processo de produção da sociedade; seja a nível material, artístico, ou seja, a nível intelectual. Um conceito de cultura que vai redirecionar as apreensões da prática normatizadoras, dos privilégios, dos direitos de cidadania, do fazersaber, dos sentidos e significados construídos pela dimensão cultural.

Os estudos que valorizam a atuação do feminino trouxeram embates ao campo historiográfico, ao denunciar o privilégio de estudos que destacavam a atuação masculina ao dar visibilidade aos espaços em que os homens atuavam e exerciam controle e poder, ao mesmo tempo em que desconsiderava os espaços femininos e mantinha a mulher à margem do processo histórico. Observando-se que, a revisão nesta abordagem historiográfica somente vai ocorrer a partir da pressão do movimento feminista pela defesa de direitos da mulher, destacando-se como movimento de grande expressão em várias sociedades que, por sua importância histórica em defesa dos direitos das mulheres, promoveram mudanças e contribuiram para a emergência do campo da Nova História, pelo reconhecimento do recorte histórico que valorizou a História da Mulher. Neste direcionamento, o movimento feminista apontou uma nova direção para a compreensão dos papeis exercidos pela mulher, sobretudo no âmbito privado, familiar, considerado como lugar em que a mulher realizava suas funções naturais de esposa, dona de casa e educadora dos filhos. Um espaço social que localizava a mulher no espaço de penumbra, do Escondido e do particular, num ambiente notadamente 
disciplinador, pois transitava neste espaço sob as amarras do controle masculino dos pais e esposos que detinham o poder e o controle político da sociedade e sobre a família.

Perrot (2007), escritora engajada na História da Mulher, considera a mulher como objeto de discursos e sujeito de saber, que apresenta uma história particular e singular da qual é sujeito protagonista, pois, os dessa autora visibilizaram às mulheres pesquisadas em meio a seus embates, suas conquistas e em seu exercício de poder tanto no espaço privado, quanto no espaço público. Destacando a condição e a representação da mulher francesa do século XIX, em suas dimensões sociais, culturais e étnicas.

A escritora em seus estudos destaca a atuação de mulheres domésticas, operárias, acadêmicas, intelectuais e mulheres em diversos outros espaços de atuação feminina e enfatiza o transitar dessas mulheres do espaço privado para o espaço público no momento em que participam de vivências coletivas, e nessa recolocação social da mulher, chama atenção para o processo de interpenetração entre os espaços privados e públicos, mediante o estabelecimento de relações sociais construtoras de laços, teias e vínculos articuladores das diferentes dimensões do espaço social.

\footnotetext{
Os rearranjos entre o domínio público e privado, a universalização dos saberes, a constituição de uma nova sociabilidade, o processo de individualização dos sujeitos e os corolários da igualdade e da liberdade [...] A visibilidade das mulheres na esfera pública se escreve também no processouniversalização dos saberes, quando a produção do conhecimento científico ganha um " mais valor", e o homem e a mulher, seus cargos e sexo, tornam-se objeto de estudo do próprio homem (VENÂNCIO, 2008, p. 286).
}

Venâncio (2008), em sua citação, reforça que os processos históricos se engendram e se revelam na interligação do privado e do público. E nessa confluência desta territorialidade, os sujeitos, os saberes e os fazeres são produzidos na dinâmica da vida societária. Assim, homens e mulheres se constituem como produtos e produtores de saberes e de culturas. Ambos, protagonistas da história e objetos do estudo histórico.

Um aspecto significativo apontado por Perrot (2007) relacionado aos estudos que versam sobre a atuação da mulher, é que estes, devem partir da apreensão da subjetividade feminina, como dimensão, que emana toda a capacidade de criação, de sensibilidade e de produção intelectual da mulher. Uma dimensão que aflora pelo acesso da mulher à instrução e a um saber que vai sendo construído pelo ler e escrever e, neste processo, o exercício da capacidade criativa e intelectual feminina. Com relação a essa particularidade, as pesquisas e estudos sobre a escrita feminine, de sobre modo na literature, como campo inicial de atuação da mulher, devem observer nesses escritos, a "alma feminina", como essência do feminina e 
dimensão reveladora da sensibilidade do ser mulher, nitidamente expressa na produção poética.

Desde o século XIX, a inserção das mulheres nos processos de alfabetização e de letramento favoreceu o aparecimento de um novo seguimento no campo da leitura e da escrita: Inicialmente, mulheres letradas e leitoras de jornais, revistas, romances, poesias e de novelas, e mulheres que adquiriram a competência do escrever e a produzir textos literários; algumas dessas escritoras conseguiram publicar seus escritos. $\mathrm{O}$ que demonstra que a entrada social da mulher no cenário da escrita e da leitura ampliada tornou-se requisito primordial para a produção de escritura feminina. Todavia, as mulheres escritoras diante de um contexto de desautorização, que negava o direito autoral sobre suas escrituras, tiveram que se submeter às imposições do cânone masculino que caracterizavam os escritos femininos como uma produção intelectual menor, o que por muito tempo colocou em dúvida a capacidade de produção da mulher. Uma forma coercitiva de desencorajar a produção intelectual foi localizar a escrita feminina num patamar de inferioridade e de desigualdade intelectual no âmbito das letras.

Na sociedade brasileira, diante da legitimação do poder, do controle e o domínio masculino sobre o feminino, algumas mulheres se destacaram e exercitaram uma atuação diferenciada se comparada com a maioria das brasileiras. Mulheres como, Adélia da Fonseca, Nísia Floresta, Berta Lutz, entre outras, que participaram ativamente na luta pela defesa de uma educação que qualificasse a mulher para o trabalho, acreditando que a educação feminina seria fator decisivo para a independência e para a inserção social mais ampliada da mulher.

Nesta sociedade extremamente hierarquizada, a compreensão a cerca da esfera pública e da esfera privada, se tornou questão reveladora do pensamento e dos valores dominantes expressos nas normas e práticas sociais que delimitavam o lugar social de homens e mulheres. $\mathrm{Na}$ verdade, tais esferas, representavam contextos sociais mediados pelas relações de poder A esfera pública sendo identificada como campo de atuação política, em que todas as decisões eram legitimadas, dessa forma, revelando-se como campo de autoridade e reconhecimento social; enquanto que a esfera privada se revestia como campo não político, sem grande expressão, por revelar as ações e práticas sociais do cotidiano, território em que estavam localizadas as pessoas comuns e mantidas silenciadas, ocultadas e obedientes diante das regras de controle e disciplinamentosocial.

No espaço do privado, as mulheres eram identificadas a partir de percepções estereotipadas, pautadas na docilidade feminina, compreendidas como traço natural e distintivo do feminino, pois a "natureza estaria na base das diferenças hierarquizadas entre 
sexos" (MIGUEl, 2014, p. 32). Na medida em que, as relações sociais estavam pautadas na autoridade masculina que limitava a autonomia feminina.

\begin{abstract}
A posição da mulher, na família e na sociedade em geral, desde a colonização [...] demonstra que a família patriarcal foi uma das matrizes de nossa organização social. As mulheres brasileiras, nas primeiras décadas do século $\mathrm{XX}$, não haviam conquistado os direitos civis garantidos ao homem. Precisavam exigir seus direitos de cidadã e aumentar sua participação na vida pública (KOLER\&NARVAZ, 2006, p.51).
\end{abstract}

A ampliação dos trabalhos produzidos no campo da história da mulher (PERROT, 1992, 2005, 'SCOTT, 1992) provocou inflexões no campo historiográfico pelos estudos dos papeis sexuais e sua diferenciação e pela incorporação de novos sujeitos e novas temáticas relacionadas à sexualidade, à criminalidade, o pecado, a morte, a vida privada, e a cultura feminina, pela valorização dos gestos, práticas e pensamentos femininos, entre outros aspectos do cenário cultural,que ampliaram as fronteiras históricas em termos de abordagens e processos metodológicos como exigências epistêmicas para dar conta da questão cultural e de representação social, matizes fundantes da Nova História Cultural.

A mulher nesse novo cenário, ganha o estatuto de novo sujeito histórico e passa a reivindicar um lugar na sociedade e na escrita histórica. Neste sentido, o direcionamento da história da mulher, segundo Del Priore (2012), foi abarcar o campo historiográfico como todo, sem restringi-lo ao território unicamente feminino e buscar novas prerrogativas para este campo, no interrogar de novas fontes documentais sobre a trajetória de mulheres, no sublinhar as questões relacionadas às divisões sexuais e partilhar a ação de homens e mulheres, então excluídos e silenciados pela história.

Tedeschi (2016) reconhece os avanços no campo da história da mulher, embora alguns questionamentos metodológicos são postos a essa vertente historiográfica relacionados à ausência de fontes e registros em arquivos públicos e privados sobre à atuação de mulheres; condicionantes então vistos como impasses ao trabalho de investigação e estudo sobre a atuação de mulheres. Entretanto uma saída é trazida pela análise dos rastros femininos em registros escritos ou de outra natureza que permitem perceber seus atos e condutas circunscritas aos parâmetros sociais ou fora desses padrões estabelecidos culturalmente. Assim, se de um lado, nos defrontamos com ausência de fontes, registros e relatos sobre a trajetória feminina, tal ausência de fontes, na verdade confirma a relação imbricada com o processo de ocultação e o anonimato da mulher; por outro lado, os escritos e os registros encontrados que enaltecem os privilégios masculinos, são referendos do poder e domínio do 
homem e, fator importante para a produção e manutenção da invisibilidade da mulher.

São dificuldades que encaminham os pesquisadores dessa área da história para a busca de fontes alternativas em arquivos particulares, que permitem o perceber da mulher em sua cotidianidade, em sua atuação no campo privado, caracterizando-se como são recortes de informações que permitem observar e o retratar das interferências provocadas pela atuação de mulheres, ainda que imersas num cenário de objeções.

\begin{abstract}
A mulher se encontrava nos arquivos (de forma) natural [...] pois, evidentemente, ela estava lá todo o tempo. Ela estava importante, necessária, ao mesmo tempo pacificadora e revolucionária. Ela era presença eloquente, trabalhadora, móvel, agitada, fecunda, desejante e desejada. Presença em relação com o mundo masculino [embora diante] a supremacia masculina: O político e a memória (DEL PRIORE, 2012, p. 225).
\end{abstract}

Um desvelar trazido por Del Priore (2012) a respeito da invisibilidade da mulher, mediante uma presença-ausência num mundo tipicamente masculino, em que sua materialidade é fugaz, fluida, quase insólita e sua presença torna-se concreta e palpável diante dos desejos e das prescrições da mentalidade patriarcal, que se mantém dominante pela ocultação e pelo não reconhecimento das contribuições da mulher. Uma representatividade da mulher reforçada pelo cenário e pelos fatos sociais que pontuam a condição feminina. Del Priore (2012) aponta um novo direcionamento ao campo da história da mulher pela adoção de uma percepção mais ampliada sobre a história de homens e mulheres localizados nos estratos "de baixo", os excluídos da história; sujeitos sem voz e direitos de cidadania plena.

\title{
1.3 O MAGISTÉRIO PRIMÁRIO SOB AS MARCAS DA PRESENÇA FEMININA
}

O cenário brasileiro entre os meados do século XIX e início do século XX apresentava uma representação de mulher sem autonomia de ir e vir, e sem direitos para conduzir sua própria vida, a mulher nesse contexto, se localizava num lugar de subalternidade. A prescrição patriarcal é regulada por mitos e por discursos que postulam a maternidade como experiência fundamental ao sentimento de completude das mulheres. (NARVAZ, 2006, p. 52) A sociedade brasileira pautada em valores conservadores construiu uma imagem idealizada de mulher e como regra deveria ser controlada por normas culturais disciplinadoras de conduta e de uma moralidade rígida a serem interiorizadas pela mulher.

O lugar de desigualdade designado à mulher era justificado pela "natureza humana" do feminino, o "corpo feminino" e seus desejos de fêmea, considerados como características 
"naturais" e marcas da inferioridade do feminino, que poderiam frustrar os projetos de vida, pensados e esperados para cada mulher. Nessa apreciação, as mulheres deveriam ser controladas e salvaguardadas pela imposição de uma imagem idealizada de mulher ingênua, recatada e submissa, a qual alcançaria a condição de redenção pelo casamento e pela vocação natural da maternidade. Um papel social que localizou a mulher a uma vida circunscrita no espaço privado do lar.

Nesta conformação social, se engendrou uma identidade feminina que situava a mulher sob a condição de inferioridade física, social e intelectual pela supremacia do poder exercido pelo homem. Uma vez que, a representação feminina imaginada e esperada referenciava uma atuação da mulher apenas como devotadas esposas e mães, enquanto que a representação do masculino era reconhecidamente relacionada a uma atuação no espaço publico e exercia no espaço privado o papel de chefe de família com poder sobre a esposa, filhos e todos os indivíduos que se localizavam numa condição de dependência do pai ou do esposo. Uma ordenação social e familiar que por séculos manteve-se na sociedade brasileira como interferente na hierarquização dos lugares sociais, cujas bases se assentavam no patrimonialismo e no patriarcalismo.

O campo da educação vai sinalizar algumas mudanças em relação à mulher quando o ensino primário no Brasil ganha abrangência nacional, a partir da criação das Escolas de Primeiras Letras em 1827, momento em que se amplia o acesso de meninos à educação e garante a entrada de meninas para o ensino público. Embora neste momento o número de escolas fosse reduzido diante da demanda dos novos alunos e da precariedade das condições de ensino.

Este sistema escolar nacional se pautava numa proposição de uma educação diferenciada para meninos e meninas. Nessas escolas se garantiu o ensino da leitura, da escrita, noções de matemática e geometria para os meninos, e para as meninas o ensino que privilegiava a leitura, secundarizava a escrita e reforçava as habilidades práticas para o bom desempenho no lar. Um saber desigual que contribuiu para as permanências da condição e do papel feminino referenciado pela sociedade vigente. Assim, a diferença educacional estabelecida para o masculino e o feminino adiou o exercício da escrita feminina e por muito tempo a mulher se vinculou a uma leitura da escrita de "outrem", outros escritores, em geral, escritores masculinos, em que se percebia sem referências para "marcar aí o seu lugar" (CERTEAU, 1994, p. 264).

Inferimos que, a pesar das amarras impostas à mulher, o acesso à educação escolar tornou-se uma importante oportunidade, pois o exercício da leitura abriu novas possibilidades 
e fez surgir um novo público de leitores, a mulher leitora, de jornais e revistas, com destaque para os romances e o acesso a todas as informações sobre a vida em sociedade. Neste momento, no recanto do lar, a mulher enxergava o mundo pelas escrituras ainda que masculinas.

Nas últimas décadas do século XIX, as mudanças socioeconômicas verificadas na sociedade brasileira, indicavam a escolarização da população, como processo precípuo para a inserção do país no cenário de modernização. Neste contexto de mudanças, homens e mulheres passaram a demandar a educação. Em especial, as mulheres começaram a buscar a escola como caminho em direção a uma inserção social para além do espaço doméstico. Um processo que vai se dando de forma gradual, mas assegurando à mulher uma dupla inserção: como aluna, o ingress a formação escolar e como professional pelo exercício do magistério primário. Apreendendo-se que nesta trajetória, a mulher em direção ao mercado de trabalho, a sala de aula e a docência se tornaram oportunidades significativas para que a mulher transitasse do espaço privado para o espaço publico.

\subsubsection{Do Lar à Escola e a Profissionalização da mulher no Magistério Primário}

O cenário brasileiro entre os séculos XVIII e XIX, o magistério foi exercido predominantemente por homens e a educação era direcionada para a formação de homens. Uma característica marcante desde a era colonial, quando a educação era ministrada por religiosos, e em substituição a esses, surgiram os primeiros professores para a ministração do ensino das "aulas régias" (ROSA, 2011, p. 3). Neste período, a educação de meninas e moças foi assegurada de forma diferenciada, pois, se destinava para as filhas dos grandes fazendeiros e das famílias burguesas, uma educação que se direcionava para a leitura e para a preparação das prendas do lar, com vistas ao casamento e aos cuidados dos filhos e as tarefas domésticas.

Nesse contexto de formação, o saber era diferenciado para homens e mulheres e promoveu uma relação desigual entre saber e poder e que conferiu ao masculino o poder de mando e domínio na sociedade brasileira. Poder que conferiu ao discurso masculino o poder de determinar o lugar social e a representação da mulher dócil, do lar e da maternidade. Uma trajetória do feminino sob as imposições masculinas. Considerando-se este ideário de mulher, o casamento era a meta a ser alcançada por toda moça de família.

A mulher era percebida e referenciada por um "corpo", como expressão de sensualidade disponível para dar atendimento ao prazer masculino, sujeito por excelência da vida social, econômica e política (LOURO, 2013, p. 17). Nessa apreciação biológica, a 
mulher foi sujeitada a um lugar social de subalternidade, na condição de ser controlado e localizado nos bastidores da vida social. Transitando nesta sociedade sob o olhar misógino da perfeição, da santidade e da fragilidade ou o seu extremo, da pecadora e transgressora da ordemsocial.

As mudanças nessa ordenação social estiveram diretamente relacionadas aos processos educativos, contexto de aprendizagem, de expressão da intelectualidade, de conquista de espaço social e a busca de prazer pela mulher. Momento, percebido como caminho de possibilidades de construção de uma condição feminina diferenciada, a partir do olhar e dos sentimentos da mulher, que provocaram mudanças no pensar e na autonomia do escrever no feminino, expressos na produção escrita de mulheres desde o século XIX. Algumas dessas mulheres conseguiram o feito de publicarem suas produces e nessas obras estavam impressos os discursos femininos sobre si, sobre a vida cotidiana, sobre as relações matromoniais, sobre as amizades, sobre os sonhos, os desejos, os devaneios e impossibilidades que passaram a ser compartilhadas com outras mulheres escritoras e leitoras desse periodo.

A mulher começou a transitar pelo espaço público somente pelo acesso à educação e à escrita. Inicialmente, as meninas, as moças, tornaram-se alunas no próprio recanto do lar e diante da ampliação da demanda social pela educação no Brasil, ampliaram-se a inserção feminina nas escolas das primeiras letras e chegaram às escolas normais, tornando-se normalistas, formação, que lhes assegurou o acesso ao magistério primário.

No cenário da educação primária, a mulher da classe média passou a ganhar maior autonomia no transitar do lar para o exercício profissional do magistério; a partir dessa inserção profissional, definida como lócus do feminino, a mulher brasileira constrói uma “outra" identidade de ser mulher, ainda que em um "lugar" profissional do "possível". Nesta profissão, algumas mulheres alcançaram destaque ao tornarem-se mulheres letradas, escritoras com reconhecimento intelectual. Uma "nova" mulher que se apropria de saberes, a partir da formação e das experiências vivenciadas na docência e nessa caminhada de "aprendente", vai se empoderando no exercício do saber-fazer e vai rompendo com as delimitações impostas às professoras primárias.

No Brasil e na maioria dos países ocidentais, o magistério se iniciou como profissão masculina, no entanto, a mulher vai se inserido no campo do magistério na medida em que vai se ampliando o número de escolas e de alunos e alunas, nas escolas elementares ou escolas de Primeiras Letras que passaram a ser instituídas em todas as cidades e vilas. Nesse contexto de expansão educacional, a educação de meninos seria ministrada por professores e a educação de meninas por professoras. Uma realidade educacional que permitirá a inserção continuada 
de professorasprimárias.

Nessa nova configuração, o magistério primário se reveste de um "processo de trabalho exercido por homens e mulheres, em que o gênero assume as marcas da diferença no exercício profissional” (ROSA, 2011, p. 1). Pois, entre os sujeitos atuantes do magistério primário, a exigência de formação diferenciada, se efetivava baseada na percepção diferenciada da educação para menino e menina. Para os professores exigia-se uma formação para além do básico; para as professoras, o estudo básico e a preparação em bordado e costura a serem ensinados as alunas. Na verdade, a instituição de um currículo diferenciado que gerou uma desigualdade salarial entre professores e professoras.

A chamada "feminização" do magistério gradativamente vai crescendo, juntamente com a expansão do sistema educacional brasileiro como exigências das profundas transformações sociais, políticas e econômicas pelas quais o país vinha passando. A contínua demanda por escolas pressionou a criação das escolas normais que tiveram como propósito a formação de docentes para dar atendimento à expansão do ensino primário. Louro (2007) observa que, a partir de 1874, a Escola Normal da Província do Rio Grande do Sul registrou o número de matrículas maior de alunas, se comparada com o número de alunos; fato também registrado em outras províncias. Uma alteração diferenciada nos interesses de alunas e alunos em relação ao magistério primário. Assim, gradativamente vai se observando que os homens vão abandonando a formação dos cursos normais e a mulher vai se tornando presença maciça nas escolas normais e no magistério primário.

O advento da República trouxe os ideários de modernidade, progresso e civilidade como símbolos constituintes da nação brasileira. Um cenário sociopolítico demarcado por mudanças significativas. O ideal republicano encenava a ampliação das atividades comerciais, industriais, e a constituição de um novo mercado de trabalho. E, diante das novas oportunidades econômicas, sociais e culturais, os espaços urbanos passaram a oferecer novas oportunidades para a atuação masculina e dessa forma, contribuíram para o a abandono dos cursos normais e a profissão docente, que passaram a buscar outros campos de trabalho promovidos pela "ampliação das atividades comerciais, maior circulação de jornais e revistas, a instituição de novos hábitos e comportamentos, especialmente ligados as transformações para a mobilização desse movimento" (LOURO, 2007, p. 449-450).

O contexto de construção do Estado e da identidade do cidadão republicano reforçou a ascendência do poder masculino e, dessa forma, este cenário sociopolítico brasileiro referendou a permanência de atividades e setores importantes como campo específico à atuaçãomasculina. 
Em contrapartida, a luta da mulher por inserção no mercado de trabalho passou a demandar a escola e a formação profissional, todavia, um novo círculo de aprisionamento da mulher se instituiu no transitar da casa para escola, da escola para o trabalho e do trabalho paara casa, pois, passou assumer uma dupla jornada de trabalho, levando-se em consideração que ao assumer novos encargos profissionais, a mulher não deixou de lado as obrigações familiares.

A inserção da mulher no magistério primário ocorreu sem a retirada da mulher de seu destino primordial: o casamento, a maternidade e o lar. Assim, o magistério se tornou a única profissão possível para a mulher, na medida em que os setores dominantes da sociedade referendavam a docência feminina como extensão da maternidade e das demais características naturais de ser mulher como "dócill", "amorosa", "paciente" e educadora de crianças, vistas e reforçadas como atribuições essenciais para o exercício do magistério.

Nesse aspecto, a mulher estaria habilitada para cuidar e ensinar crianças e o magistério feminino estaria vinculado à tradição religiosa que, concebia o magistério como sacerdócio e não como profissão, mas como uma atuação feminina extensiva à função primordial do feminino: a maternidade; reconhecida como qualificação natural ao magistério, em um momento de ampliação da rede escolar e da necessidade contínua de novos professores para atendimento a demanda social pela educação.

O período da Primeira República foi marcado por uma forte cultura política autoritária e excludente que determinou um processo de construção da cidadania a partir de critérios sexistas, étnicos, raciais, classistas e culturais, concebidos então, como fatores estruturantes da vida em sociedade e que estabeleceram para a mulher, a condição de dependência e de subalternidade. Compreendendo-se que a educação republicana não se voltava para a emancipação feminina, seu ideário progressista e civilizatório manteve o controle disciplinador sobre a mulher tornando-a sujeita ao desrespeito e aos processos de discriminação e à exploração de toda ordem.

Nesse contexto político, observou-se o empenho do poder instituído em promover a ampliação da escola primária como condição precípua para a efetivação dessa nova ordem política, a República, sob os ideários da modernização capitalista a ser alcançado por um novo cenário educacional que viesse subsidiar as bases do nacionalismo. Para tal, tornava-se necessário romper com o analfabetismo pela ampliação do número de escolas e pela promoção de acesso aos grupos populares, mantidos fora dos processos escolares. A grande preocupação do governo se centrava na instituição de uma educação nacional que promovesse a redução do analfabetismo, o sentido de brasilidade e o sentiment de pertença nacional por 
via dos processos de civilidade do povo brasileiro.

A escola nesse cenário se transformou em veículo principal para a efetivação dos valores nacionalistas, base norteadora das condições de pertencimento e de vir a ser enquadrado como cidadão republicano. Segundo Souza (2011), a coletividade somente se reconhece pela força da abstração e se reconhece pelos elos invisíveis referendados, pois nesse processo de reconhecimento e sentimento de pertencimento se expressam por laços de solidariedade coletiva, a partir da construção de laços pautados em fatos e conjunturas que estabelecem uma liga identiária que cimenta os laços sociais, culturais e políticos.

Diante desse papel social da escola, o sistema educacional se amplia no cenário nacional e promove o acesso de grupos sociais, até então excluídos, entre esses, a inserção mais ampliada das meninas e moças que passaram a transitar do lar para a escola, ampliandose a formação continuada mediante a criação de escolas "normais" no país, requisito de formação para o mercado de trabalho na área da educação.

\subsubsection{A feminização do Magistério e a Subalternidade da mulher}

Diante de uma organização social que referendava a predominância da figura masculina e impetrava ao sujeito-mulher sua destituição do espaço público, do espaço de visibilidade e de participação social, pelo não reconhecimento de um sujeito autônomo, e sem direito á expressão de suas vontades, desejos, sentimentos, necessidades, interesses e pensamentos. Um condicionamento histórico que por séculos a mulher foi "agasalhada numa capa de silêncio (e) parte das mulheres desenvolveu uma espécie de mutismo ambíguo, vivendo seu corpo apenas como função procriadora de seus herdeiros para o contínuo refazer da família e da comunidade" (SANTOS, 2009, p. 11). Condição e posição social do feminino outorgadas e mantidas por séculos pela ingerência do poder masculino dominante na organização societária brasileira.

Nessa conformação social, a inserção feminina no espaço escolar público se inicia com a criação das Escolas de Primeiras Letras, que diante de uma realidade educacional precária, marcada pelo alto índice de analfabetismo de homens e mulheres, passou a promover o acesso de meninas à educação escolar. Amulher passou a ser inserida em um novo cenário, anda que marcado pela precariedade do ensino, possibilitou a presence feminina no magistério por conta da escolarização de meninas, que se dava separado do ensino de meninos e que pelas normas educacionais vigentes, deveria ser ministrado por professoras.

Pautando-se em Louro (2007), a formação de professores normalistas, exigia de 
professores e professoras um "exímio" caráter moral, uma vida regrada e exemplar para o ensino primário de meninos e meninas. As figuras de professores e professoras eram vistos como modelos a serem seguido, como segundo "Pais espirituais" que conduziriam a formação educacional e a formação identitárias de crianças e jovens que adentravam na escola pública.

No entanto, a diferença curricular entre professores e professoras do ensino primário na verdade, ressaltava a questão de gênero, como elemento revelador no processo de instituição da representação de homens e mulheres no campo da educação, como resultante de valores socioculturais tradicionais partilhados em relação aos papeis sociais ocupados por homens e mulheres subsidiados a partir de uma cultura patriarcal e misógina, que manteve ao longo do tempo um lugar diferenciado e desigual da mulher no exercício do magistério primário; embora, a atuação de professores e professoras fosse reconhecida como importantes na efetivação da uma educação para a formação do cidadão republicano e para o progresso do país.

Os ideários republicanos voltados para o alcance da civilização e da civilidade do povo brasileiro se tornou uma aspiração que motivou toda elite governante brasileira para civilizar o território, mediante o empreendimento de uma nova base de sustentação que desse aporte à celebração do progresso e de patamares civilizatórios, como representação da nação brasileira no âmbito das nações capitalistas. Nessa direção, o empenho para a renovação das cidades e a reformulação de condutas e costumes do cidadão brasileiro.

Segundo D'Incão (1997), a “proposta era ser civilizado, como eram os franceses e os europeus em geral". Nessa concepção, o espaço urbano brasileiro teria sistematicamente que lutar contra comportamentos, atitudes e expressões tradicionais consideradas inadequadas para a nova situação ou ordenação exigida pela modernidade. O que demonstra neste processo de construção do sentido da nação brasileira, a exigência de um disciplinamento da população que deveria se submeter aos novos códigos de condutas e posturas tidas como civilizados. No país, adotam-se valores e regras idealizadas, ao conceber-se a nação como uma realidade única, homogeneizada e silenciadora das desigualdades de classe, de raça, de cultura e de gênero entre homens e mulheres; adotando-se assim, uma concepção de autonomia e soberania pautadas em ideários tradicionais, conservadores que invisibilizaram o perceber e a garantida do direito à alteridade ao se descartar nessa concepção, o reconhecimento das manifestações culturais manifestas.

No âmbito da educação, Vidal (2001) esclarece que as políticas implantadas pelo Estado, referendavam o papel da educação na construção e na efetivação do pensamento nacionalista como proposta republicana. A escola se constituiu em veículo principal para a 
promoção do nacionalismo, do pertencimento e da cidadania nos tempos modernos. Nesse contexto formador, a escola pauta sua ação educativa em manuais didáticos revestidos dos “discursos fundadores da nacionalidade". Assim, a implantação de uma política educacional do Estado estava voltada para a formação cívica do cidadão brasileiro. A escola amplia esse papel formador, a partir do momento em que o ensino primário se torna obrigatório e o Estado passa a ter uma ingerência maior sobre o sistema de ensino. A escola republicana oferecia à população uma formação básica, elementar e assumia um papel central na reprodução do modelo societário brasileiro, dos valores culturais, políticos e civilizatórios do EstadoNação.

No Brasil, a demanda social pela educação volta a inserir-se na agenda governamental como lugar central, a partir da década de 1930, momento político marcado pela transição do modelo agrário exportador para um modelo urbano industrial. Segundo Palma Filho (2010, p.85) e Romanelli (1999, p. 59), como estratégia econômica para a saída da crise internacional de 1929, o Brasil promoveu o rompimento com as bases de sustentação das oligarquias agrárias e, estabeleceu alianças com os grupos atrelados ao capitalismo. No campo educacional, a emergência do Manifesto dos pioneiros da educação em defesa da Escola Pública vai se ampliando diante da realidade de um sistema educacional deficitário e de uma proposição tradicional de educação e de ensino que não permitia o acesso das camadas populares. O que demonstra que, o Estado na Primeira República não conseguiu cumprir suas metas em implantar um Sistema Nacional de Educação que viesse assegurar os ideários desenvolvimentistas.

Nesta direção, a Escola Nova, advogada pelos educadores voltava-se então, para a conquista da civilização contemporânea, enquanto sinônimo da própria libertação do homem, pelo ensino centrado no saber técnico, tecnológico e científico. Acreditando que, a adoção do espírito científico positivista promoveria a elevação do homem, uma vez que, o olhar científico possibilitaria o avanço para as invenções que revolucionariam os meios de produção, de pensamento, de cfenças e das instituições sociais, assim, romperia com uma mentalidade antiga ou vista como atrasada e adotaria um novo pensar de homens e mulheres idealistas e práticos, ao mesmo tempo que se instalaria no país uma nova consciência educacional como caminho para a introjeção de uma civilização moderna.

Nesse sentido, a educação e a escola, assumem a missão de salvaguardar a Pátria na implantação de um novo modelo de estado e de sociedade, mediante uma ação educativa para a formação do povo brasileiro, com vistas à qualificação do trabalhador para as novas exigências da economia capitalista. Exigindo-se da educação e da escola pública, uma atuação sistemática e ampliada para a inserção das camadas populares, considerando-se a realidade 
dicotômica da sociedade brasileira, enquanto:

\begin{abstract}
Uma sociedade (eminentemente) agrária (em que seus representantes majoritários ocupam) os principais cargos da república, (e) uma sociedade urbano-industrial ainda muito dependente da economia agrária, e que reclama novas relações sociais, não só com o capital, mas também do próprio pensamento. Em meio a essa disputa o entusiasmo pela escolarização. Surge, de um lado, pela crença de que a multiplicação de instituições escolares seria possível incorporar grandes camadas da população na vereda do progresso nacional e colocar o Brasil no caminho das grandes nações do mundo [...] As formulações sobre a escolarização (indicavam) o caminho para a verdadeira formação do novo homem brasileiro (SOUZA, 2011, ANAIS, ANPUH).
\end{abstract}

A formação de novas gerações para o mercado produtivo brasileiro, em processo de expansão, oportunizou a contínua expansão do sistema educacional brasileiro, a ampliação das escolas normais e a entrada massiva de mulheres diante das transformações e exigências sociais, políticas e econômicas, o que gerou uma nova organização e conformação das bases nacionais da educação a partir do processo de feminização domagistério.

O processo de feminização do magistério primário nesse contexto histórico e educacional oportunizou uma compreensão deste fenômeno, como resultante de um processo histórico "relacional construído na dinâmica das relações de gênero, e problematizado na desnaturalização dos papéis sociais desempenhados pelos gêneros no processo histórico da escolarização" (CARDOSO 2011, p.18); percebido, então, como fruto da relação desigual de poder entre homens e mulheres, visto como processo natural e imutável, construído por uma sociedade patriarcal e seus valores socioculturais que referendava o poder e o lugar desigual entre homens e mulheres. No âmbito da docência, são observados os processos reprodutivos centrados nas marcas da diferença e da desigualdade no exercício de uma mesma profissão, o magistério primário, ministrado por homens e mulheres.

Neste momento em que as mulheres se tornaram a maioria do professorado primário, a inserção da mulher neste campo profissional eminentemente feminino, ocorreu sob o olhar de intelectuais, políticos e homens de destaque com o poder de interferir e ditar normas e concepções de educação que passaram a reconhecer a presença feminina no magistério como atuação de continuidade das atividades exercidas pela mulher no espaço familiar. Assim, se estabeleceu uma vinculação do magistério como profissão feminina, a partir das características vistas como naturalmente femininas, como ser mãe e ter experiência inegável de cuidar e de ensinar crianças. E a abnegação nesse fazer e nesse cuidar qualificava as mulheres para o exercício do magistérioprimário.

Nessa conformação de papéis sociais, emergiu uma representação de professora como 
mãe de família e "mãe" espiritual de crianças que passaram adentrar nas escolas primárias. O ideário de mãe é associado à função docente, justificado socialmente pelo esforço, pelo empenho, pela doação e entrega das professoras no ensino de crianças. O magistério feminino se revestindo então, de um caráter missionário, descaracterizando a atuação feminina no ensino primário como carreira profissional.

Apesar da contínua desigualdade e rebaixamento da atuação feminina, o magistério primário adquiriu reconhecimento e prestígio social junto às mulheres, se comparado a outras ocupações femininas. Assim sendo, tornou-se oportunidade profissional para as mulheres, que sob o referendo da sociedade, vão se apropriando desse espaço no mercado de trabalho, pela possibilidade de maior circulação, de visibilidade da mulher no espaço público e meio de subsistência econômica para a mulher. A professora nesse lugar do possível passou por um processo de reconstrução identitária, pela diversidade de papéis: mulher, mãe, esposa, professora religiosa, sujeito aprendente e construtor de saberes.

Para Vieira (2002), a feminização do magistério se expressa pelo crescimento massivo da presença feminina no magistério e entre o período de 1920 a 1930 a presença da mulher no magistério primário era em torno de 72,5\% em relação a totalidade dos docentes do ensino primário. Nas décadas de 1960 e 1970 se observou a ampla inserção da mulher no mercado de trabalho brasileiro se mantendo a predominância feminina no magistério.

Uma das razões desse crescimento apontado por Viera (2002) está relacionada à identificação da docência primária como campo profissional de atuação feminina; outras razões estavam relacionadas ao contexto social, econômico e político, que promoveu a inserção do homem em outras experiências profissionais oportunizadas pelo context de modernização, que promoveu a dinamização do mercado de trabalho e a diversificação de atividades econômicas.

Louro (2011) informa que os homens que permaneceram no campo daeducação primária passaram a se localizar em outras modalidades de ensino e, ou passaram a ocupar cargos administrativos ou técnicos, ao assumirem os cargos de supervisores e administradores das escolas. Nessa reordenação no magistério, surgem novas interferências, imposições e direcionamentos diante do novo lugar de destaque assumido pelo masculino em um campo notadamente feminino. O sistema educacional mantém a valorização da atuação do masculino e desqualifica a atuação do feminino. Uma questão consequente neste momento trazida pela apreensão da professora Renata Marques da Rosa (2011), "Sendo a mulher professora presença marcante na nossa educação (desde então) se faz necessário uma análise a partir da definição do que é ser mulher em nossa sociedade e quais influências desse estereótipo 
feminino na docência". Uma preocupação que perpassa pela questão de gênero, na qual, o sexo em suas apreensões do masculino e do feminino, tornou-se determinanteno reconhecimento do saber-fazer do homem e da mulher em nossasociedade.

Segundo Vieira (2002), a presença massiva de mulheres no magistério primário gerou uma hierarquização salarial entre homens e mulheres. Um processo gerado pela percepção estereotipada do lugar e do papel de homens e mulheres, pela qual, o sistema educativo definia a remuneração feminina e a masculina. A remuneração da professora era compreendida como complementar da renda familiar, enquanto que a remuneração do professor era concebida como salário de provedor familiar. $\mathrm{Na}$ verdade, a diferenciação financeira se subsidiava numa compreensão da identidade de homens e mulheres, fruto de uma construção social vivenciada e interiorizada, a partir do modelo social vigente da sociedade brasileira: patrimonialista e patriarcal, que asseverava a permanência do lugar de destaque do homem na sociedadebrasileira.

A educação da professora deveria observar a condição de fragilidade da mulher e nesse sentido deveria ser diferenciada da educação de professores. Nesta educação, a exaltação do recato, da beleza e da domesticidade como atributos a serem ostentados pelo esposo e familiares nos eventos sociais, como mulher rainha do lar e mãe exemplar. Uma condição feminina que é extrapolada à educação feminina e ao exercício profissional na docência pela diferenciação salarial pago ás professoras primárias.

Em relação aos baixos salários pagos às professoras, gerou-se um nível devida modesto promovido pela segregação sexista presente no trabalho da docência. A diferença salarial se justificava pela concepção de que o trabalho feminino no magistério identificado como sacerdócio que referendava uma atuação feminina missionária, quase religiosa do que uma profissão propriamente dita. Apesar das exigências postas à educação e a qualidade do ensino, o magistérios feminino, transitou entre uma responsabilização qualificada para alcance dos fins propostos e as condições de "pauperização" do "fazer pedagógico" e sua interferência nas próprias condições de vida das professorasprimárias.

Retrato da docência feminina explicitado por Almeida (1998) e representação submetida à um contínuo processo de desvalorização:

A profissão do magistério que, a princípio foi ideologicamente erigida como dever sagrado e sacerdócio por conta da tradição religiosa do ato de ensinar, tornaram-se, na segunda metade do século $\mathrm{XX}$, alvo de denúncias de proletarização e desvalorização, ora colocando professores e professoras como vítimas do sistema, ora como responsáveis pelos problemas educacionais que afligem o país (ALMEIDA, 1998, p, 15). 
Nesta citação, a autora traz a tona uma reflexão a respeito da "ambiguidade do ato de ensinar" e uma apreensão sobre a história da educação brasileira e sua vinculação à realidade econômica, política e social. Assim, a história da educação tem sido resultante da relação imbricada entre o papel da educação e as exigências do contexto nacional, cujos resultados, são atribuídos á dedicação e o devotamento dos educadores, ainda que num contínuo processo de desvalorização da docência. Situação acirrada pela presença massiva de mulheres no magistério primário.

\subsubsection{Relações de Poder e os mecanismos de controle da Professora Primária}

A inserção da mulher no magistério ocorreu a partir de uma identificação da professora primária em estreita relação ao modelo idealizado do feminino sob as marcas da "subalternidade", expressa pelo discurso masculino que revelava a mulher como ser frágil, com uma intelectualidade menor, pelas características delineadas pelas condições naturais de ser mulher.

Uma representação tida como verdadeira também passou a referenciar a condição de inferioridade da mulher professora, se comparada ao reconhecimento social da figura masculina.

No contexto da educação feminina, a mulher deveria receber uma educação que se adequasse à maneira de ser mulher. Assim, se instituiu uma educação feminina pautada em valores, normas sociais vigentes e princípios disciplinadores que mantiveram o lugar subalterno do feminino, a partir de uma construção de uma imagem de mulher "recatada" e responsável "pela manutenção de uma família saudável e para tal, deveria dedicar-se com esfera à formação e conservação dos vínculos familiares” (FREIRE, 2011, p. 3).

Neste referencial do lugar social da mulher, a competência profissional e intelectual das professoras não era reforçada, ao se considerar que, a preparação para atuação das mulheres no magistério deveria estar situada no limiar da "segurança do casamento e do lar". Assim, os discursos masculinos patriarcais estabeleceram, neste âmbito de atuação do feminino, condutas, posturas e diretrizes para docência. $O$ fazer, o atuar e o pensar feminino na educação primária deveriam estar circunscritos segundo a ordem social vigente que, ao liberar a mulher para o mercado de trabalho, também estabeleceu imposições, limites e condições que cerceavam a autonomia e a visibilidade da atuação da professoraprimária.

A formação da normalista e o exercício do magistério primário refletem a inserção da 
mulher no campo educacional, embora em meio a posições divergentes; por um lado, alguns discursos vigentes reconheciam o despreparo intelectual da mulher normalista e da professora para educar as crianças, os futuros cidadãos; por outro lado, a enunciação de discursos que afirmavam a natureza feminina como elemento essencial para a atuação da mulher no campo da educação.

Segundo Rosa (2011) nesses embates, os discursos mais tradicionais enfatizavam o trabalho da mulher como professora e em outras atividades femininas, se essa inserção no mercado de trabalho não viesse de alguma forma prejudicar a educação dos filhos, as responsabilidades com o marido e os afazeres domésticos; responsabilidades que deveriam ser cumpridas pelas mulheres. A condição feminina sendo extrapolada à condição da mulher no exercício profissional, enquanto, uma representação inscrita no discurso do "outro" pela ausência autodeterminação.

Uma representação da mulher professora naturalizada pelo imaginário que foi sendo construído, a partir do contexto cultural brasileiro vigente, diretamente relacionado à questão de gênero e aos padrões sociais que situam estrategicamente os indivíduos nos processos de inclusão e exclusão social.

Do ponto de vista político e educacional, os estereótipos produzidos sobre a mulher e a docência feminina, promoveram a democratização do ensino primário a partir de uma atuação eminentemente feminina, mas desqualificada como defesa de um discurso reconhecido e legalizado em um contexto em que a ação do masculino foi dominante, pois:

\footnotetext{
Para que a escolarização se democratizasse era preciso que o professor custasse pouco: o homem que procura ter reconhecido o investimento na formação, tem consciência de seu preço e se vê com direito à autonomia - procura espaços ainda não desvalorizados pelo feminino. Por outro lado, não se poderia exortar as professoras a serem ignorantes, mas se podia dizer que o saber não era tudo nem o principal. Exaltar qualidades como abnegação, dedicação, altruísmo e espírito de para sacrifício e pagar pouco: não por coincidência esse discurso foi dirigido às mulheres (CATANI, 1997, p. 28).
}

Uma condição de inserção social delimitada pelas marcas da diferença de ser mulher, enquanto condição subsidiada em uma mentalidade sociocultural dominante a respeito da maneira de ser mulher, referendada e imposta pelos meios políticos, religiosos e educacionais que sob a direção do masculino, delimitavam o trânsito feminino aos contornos do lar, da igreja, do convívio social e depois no espaço escolar; espaços esses, vigiados pelo olhar do pai, familiares, do esposo e das autoridades institucionais. Os seja, pelos representantes da sociedade patriarcal. 
A mulher, ao se tornar presença dominante do magistério primário, continuou a exercer o papel de mantenedora da segurança do lar, e na era republicana, passou a ser responsabilizada pela salvação da Pátria, como educadora das futuras gerações de cidadãos republicanos.

A formação da mulher e da professora primária continuava regida pelas doutrinações religiosas da Igreja Católica, que implicavam no controle da sexualidade e da feminilidade. Os ritos religiosos como o casamento, o batismo e demais preceitos religiosos funcionavam como normas dominantes que impetravam exacerbado controle e vigilância sobre "o corpo" e a "alma" das mulheres; e associadas aos processos educacionais, desenharam a conformação de um "ser mulher" disciplinado e obediente aos ditos e escritos do segmento autoritário que, pelo poder de mando e domínio, impuseram suas ideologias dominantes aos grupos subalternizados.

O controle e vigilância acompanhavam o ir e o vir da mulher no espaço público e em relação ao trânsito da professora. Vidal (2001), a partir de relatos de algumas professoras que vivenciaram esse cenário de vigilância, afirmam que: “Aprofessora, ao sair da escola, deveria dirigir-se diretamente para a casa e andar sempre em grupo para evitar falatórios"; O que transparece nessas observações é que, além do excessivo cuidado, fica bem expresso o sentido da vigilância sobre a professora primária no seu caminhar do lar para a escola e da escola para o lar. Um trajeto vigiado entre o privado e o público, diante das observações de algum perigo ou de se evitar comportamentos para além do esperado, considerados então, como transgressores ou fora da moralidade estabelecida.

Por outro lado, exigia-se da professora a abnegação, virtude, amor, dedicação, vocação como qualificações para o exercício do ofício da docência feminina, enquanto trabalho demarcado pelo caráter missionário. Uma atribuição, que levou algumas professoras a optarem por casamento tardio e ou por uma vida celibatária para que pudessem se dedicar exclusivamente ao magistério. Escolhas que estiveram relacionadas a pesadas responsabilidades atribuídas às professoras primárias, a saber:

\footnotetext{
A personificação do ideal da professora da escola elementar foi se cristalizando ao longo dos anos no imaginário social como um profissional da virtude, do amor, da dedicação e da vocação. A mistificação da ação educativa (como) uma das características mais fortes do ideário de professora. A dignidade do ofício, a nobreza de sua missão, a exaltação do zelo só comparável às causas religiosas e patrióticas (CHAMON, 2006, p. 2).
}

A caminhada das professoras primárias é marcada e cobrada pela responsabilidade de 
ser mulher professora primária, em meio a um cenário de desvalorização salarial, das condições precárias de ensino e da ação autoritária dos dirigentes da educação. A professora Jane Soares de Almeida (1998,) no livro "Mulher e Educação: a paixão pelo possível” faz algumas observações a partir da citação de um trecho presente no romance "O Calvário de uma Professora", de autoria de Dora Lice, como pseudônimo e publicado em 1928. A professora Jane Soares de Almeida traduz o dilema de uma personagem "Hermengarda" como professora, no transitar entre limites e dificuldades impostos pelo campo da educação, especialmente a atuação de uma mulher no magistério primário. E a partir da leitura deste romance em suas entre linhas, chegou a seguinte apreensão dos enunciados trazidos pelo livro de Dora Lice (1928):

\footnotetext{
O livro segue narrando uma série de desgraças acerca das mazelas de sua vida de mulher e da profissão escolhida, desde a perseguição dos homens que dirigiam o sistema educacional até a rejeição dos colonos da zona rural, onde foi primeiramente lecionar. A jovem professora demonstra sua revolta pela condição de desigualdade a que eram submetidas às mulheres em geral, a opressão dos homens e a negação de direitos [...] (ALMEIDA, 1998, p. 37).
}

Considerando-se à apreensão de Almeida (1998) sobre os escritos de Dora Lice (1928), percebe-se que ao final da segunda década do século XX, as permanências dos valores culturais que justificavam a condição de mulher e professora no país. As relações de poderes apresentam-se ainda pautadas nos processos de desigualdade de gênero e definidoras do poder masculino no exercício de cargos de mando ou de direção, que atribui ao masculino, o poder para perseguir e oprimir. Tal condição social estereotipada e discriminada da professora ainda se mantém nesse momento e em alguns aspectos na atualidade. Tornando-se emergente, o repensar dos paradigmas culturais que ainda sustentam a mentalidade patriarcal e machista, em relação à condição feminina tão latente na sociedade brasileira, e tão presente em relação à violência e a desigualdade, que coloca em situação de vulnerabilidade, no momento em que o avanço das leis assegura direitos, proteção à discriminação e à violência contra asmulheres.

Considerando o cenário do magistério primário, as trajetórias de professoras do ensino primário se constituíram e ainda se constituem na atualidade, nesse território, como uma área de fronteira, pois no limiar desse território as professoras vivenciaram as marcas do poder de mando masculino, do disciplinamento, do silenciamento e do apagamento das mulheres professoras; no entanto, estas professoras paulatinamente ao longo de sua trajetória profissional, a partir de suas vivências no ofício de ensinar, foram construindo experiências para além do estabelecido e nesse caminhar encenaram uma história feminina para além do 
controle e disciplinamento; e alçaram voo, se transformaram como mulher, como professora e tornaram-se sujeitos produtores com novas identidades de ser mulher, fazendo emergir maneiras diferenciadas, plurais e singulares na maneira de ser, pensar, escrever e viver como mulher, considerando nesse processo, todas as dificuldades e limitações impostas àmulher.

\subsubsection{O Magistério Primário como entre lugar do possível: Lócus da emergência de novas Identidadesfemininas}

O magistério feminino por ser associado às potencialidades naturais da mulher e aos papeis sociais do cuidar, referenciado pelo dom da maternidade e pelo casamento, a docência tornou-se extensão dessa imagem idealizada da mulher-mãe. O Magistério se tornou espaço de atuação feminina, vigiado, limitado, desqualificado financeiramente e espaço regido por normas e princípios disciplinares, que limitavam a autonomia profissional e a emancipação feminina. Considerando que a atuação feminina no magistério se revestiu como concessão permitia às mulheres, mães de famílias e mulheres solteiras normalistas c que apresentassem uma conduta moralilibada.

O transitar da mulher pelos caminhos da educação e por suas vivências cotidianas na sala de aula, tornou estes lócus de atuação profissional da mulher, lugar de produção sentidos e significações para a vida e para o exercício profissional da mulher professora. Por se constituir espaço de aprendizagem, de autonomia profissional e de emancipação da mulher. No exercício do magistério a mulher passou a ter maior visibilidade, autonomia e reconhecimento do saber-fazer na docência. Um exercício profissional que apontou possibilidades de acesso a outros espaçossociais.

Como exemplo do processo de descolamento da mulher, a trajetória singular de algumas professoras, que pelos caminhos da educação ganharam notoriedadecomo professoras comprometidas com a educação no país, pela defesa de uma educação qualificada para a população e de forma incisiva para a formação feminina. Entre tantas professoras, a história da educação registra a atuação singular de Nísia Floresta (1810-1885), da professora Armanda Álvaro Alberto (1892-1974) e entre os professores no Estado do Pará, as professoras Hilda Vieira, Maria Antonieta Serra Freire, Poranga Jucá, Palmira Lins de Carvalho entre outras mestras valorosas, que nomeiam escolas públicas e dentre estas professoras, destacamos a atuação de Ester Nunes Bibas (1888 -1972), como sujeito-objeto deste estudo presente.

São mulheres "ímpares", singulares, que a partir de suas vinculações com a educação e 
a docência, deixaram suas experiências e contribuições nesse campo de atuação. Além do exercício do magistério se tornaram escritoras de textos impressos, produziram livros artigos e escrituras poéticas. Nísia Floresta se tornou grande referência de mulher atuante no transitar pelo século XIX; fundou escola para moças e participou ativamente pela defesa de uma educação que promovesse a emancipação feminina, tornou-se escritora e poetisa. Escreveu sobre os direitos da mulher, dos índios e dos escravos. Mas seu grande legado foi romper com os limites entre o espaço privado e o espaço público. Transitando também pelos caminhos da literatura e da poesia. Armanda Álvaro Alberto, além de criar a Escola Regional de Meriti, assumiu a direção desta escola e nesse seu transitar pela educação primária, foi presidente da Associação Brasileira de Educação e fundou a União Feminina do Brasil, o que demonstra seu envolvimento com a educação nacional e com o movimento em defesa da educação feminina e os direitos da mulher, e militou em defesa da valorização das mulheres professoras. E neste momento, registrar a atuação da professora Ester Nunes Bibas, no magistério primário no estado do Pará e no campo da poesia, campos em que a professora se tornou escritora de livros. (MEC, COLEÇÃO EDUCADORES, 2010).

São exemplos de mulheres militantes na educação, com histórias de vida singulares, que ao longo de seu caminhar foram construindo trajetórias, a partir de outro discurso e uma prática diferenciada para o campo da educação e fizeram emergir outra representação do feminino: a mulher atuante no e do magistério primário.

Sobre esse emergir de novas identificações da mulher professora, as professoras Diana Gonçalves Vidal e a professora Marta Maria Chagas Carvalho (2001) em suas análises sobre a questão do magistério primário destacam no processo da feminização da docência, aspectos importantes para se compreender o lugar profissional, em que a mulher adentrou e se tornou dominante, considerando que:

\footnotetext{
Nos estudos históricos, o processo de feminização da profissão docente - E aqui pensamos especialmente nas séries iniciais da escolarização, que no Brasil, historicamente, vem sendo chamadas de Curso Primário - tem sido frequentemente associado apenas ao ingresso majoritário de mulheres. A mudança na composição sexual do corpo docente entre os meados do século XIX e o início do século XX (VIDAL, 2001, p. 212).
}

Essas autoras, a partir dessa percepção, realizaram uma análise relacionada aos estudos sobre esse processo tão evidenciado na história da educação brasileira, e chamam a atenção do pesquisador do campo educacional para o fato de que a feminização do magistério não se reporta apenas para a composição sexual do magistério primário, mas também para se 
pontuar nesses estudos, as observações e implicações desse fato reconhecido, a partir das significações trazidas pela atuação feminina no campo da educação. As autoras observam que, embora, esse processo de (re)significação da atuação docente não seja linear, pois, ao se constituírem como construção, esse processo vai se dando em meio a conflitos pessoais, institucionais, discursos polêmicos a respeito da masculinidade, da feminilidade, prescrições, controles e expectativas esperadas para professores, homens e mulheres. E o magistério primário deve ser percebido como um campo em que se dá o entrecruzamento de abordagens epistêmicas, dos diferentes saberes escolares e práticas educativas, consideradas como "métier" " do professor e como campo nitidamente discursivo pelos enunciados dos chamados grandes homens de letras, de ciência e da educação e nesse campo minado pelo masculino, os discursos advindos da fala e dos escritos de algumas professoras primárias e mulheres que empunharam a bandeira de luta em defesa da mulher e da educação.

E nessa trajetória, empreendemos uma compreensão a respeito dos processos identitários construídos no território da docência feminina. Observando-se a atuação de algumas professoras, apreendemos que tais processos de identificação da mulher professora perpassaram para além do instituído e do esperado, e impõe a necessidade de um olhar ampliado sobre o cenário sociocultural em que esses sujeitos estão inseridos, sobre os processos de construção de conhecimentos, apropriação de saberes, a efetividade das práticas pedagógicas, e sobre os processos de ensino-aprendizagem que remetem ao estabelecimento de relações sociais com os demais professores e alunos, enquanto sujeitos "concretos" do processo de escolarização. Um espaço com possibilidades de proposições e construções estratégicas, como saídas às limitações do fazer pedagógico.

$\mathrm{O}$ que nos leva a perceber que o magistério primário como espaço contraditório e fronteiriço por possibilitar permanências de posturas e de uma cultura escolar tradicional, como também, a emergência de novos saberes, novos olhares sobre a cultura, a educação, a escola e sobre os processos pedagógicos, como aprendizagem do sujeito do conhecimento; possibilidades que se materializaram e passaram a gerar inflexões e mudanças para esse espaço e para os sujeitos nele inserido. Caracterizando-se então, como um "entre-lugar", com área fronteiriça, marcada pela ação construtiva dos sujeitos envolvidos, num processo de continuidade e descontinuidade, que vão conformando novas identificações de ser professora primária, ainda que atravessadas pelas permanências e mudanças vivenciadas nesse território fronteiriço. Percepções e elocuções que se pautam nos estudos de Bhabha (1998) e Santiago

\footnotetext{
${ }^{6}$ Termo oriundo do francês que significa: "ter a profissão"; "levar a vida de".
} 
(2000).

A partir dessa percepção do magistério e da docência feminina, a construção da identidade da mulher professora não corresponderia ao ideal instituído socialmente, e sim, por um processo que entrecruza com o instituído e com os novos sentidos atribuídos ao seu fazer como mulher e como professora. E a partir desse emaranhado de saberes e experiências, emergem novas expressões identitárias de ser mulher. Nesse contexto de atuação do feminino, o conceito de "entre-lugar" passou a ser utilizado nesse campo de localização do feminino, a partir das contribuições de Silviano Santiago (2000), na obra "Uma Literatura nos trópicos" (2000), o conceito utilizado como elemento de análise pelos estudos culturais, com aproximações ao conceito de zona ou de território intersticial desenvolvido por Babha (2013), assim como se aproxima do significado de fronteira, regiões ou territórios de fronteira, então trabalhados por Anzaldúa (2007). Spivak (2010) concebe os espaços fronteiriços, como lugar de "inquietude e problematizador" para os sujeitos periféricos, excluídos e ou subalternizados. Neste trânsito pela fronteira, o identificar do papel ou dos papéis desempenhado(s) pelos sujeitos situados na fronteira.

Santiago (2000) utiliza o termo "entre-lugar" como "operador" de leitura e interpretação de enunciados e lugar de diferentes facetas identitárias. Bhabha (2013), no livro O Local de Cultura, embora, traga a preocupação com o pensamento pós-colonial, na compreensão do sujeito colonial, se contrapõe ao essencialismo ou aos determinismos nos processos de identificação. Para este autor, há um espaço intersticial entre as imposições da cultura colonizadora dominante e os padrões culturais dos povos colonizados e complemente que neste lugar:

O trabalho fronteiriço da cultura exige um encontro com o "novo" que não seja parte do continua de passado e presente. Ele cria uma ideia do novo como ato de tradução cultural, essa arte não apenas retoma o passado como causa social ou precedente estético; ela renova o passado, refigurando-o como um "entre-lugar [...] (BHABHA, 2013, p. 29).

Nessa compreensão, o magistério primário e a docência feminina são concebidos como "entre-lugar" ou região fronteiriça, em que a mulher professora primária se localiza nesse território a partir do seu movimentar e atuar como sujeito fronteiriço. O processo de

\footnotetext{
${ }^{7}$ Em Silviano Santiago (2000) o termo “entre-lugar” passou a ser utilizado nos estudos de formação discursiva nos estudos literários, de campo das ciências humanas e estudos culturais. Em Bhabha (2013), no livro O Local de Cultura. Na Zona intersticial, em que o sujeito se vê e se redefine.
} 
identificação do lugar e da identidade da professora primária não é dado apenas pelo instituído, mas reconhecida e compreendida, a partir da percepção do processo dinâmico, então construtor dessa identificação, que envolve as representações idealizadas e reconhecidas e pela atuação do professor, e diante das limitações, das contradições desse lugar instituído, dos padrões socioculturais, das relações de gênero, este processo de construção que vai sendo instaurado, e aponta para esse sujeito fronteiriço, possibilidade estratégicas para a revisão de seu papel, de sua atuação e de seu lugar alcançado ou buscado. Processo que se revela como pessoal, singular, embora, inserido num contexto educacional e social maisampliado.

A conformação de outro lugar é resultante das experiências vivenciadas na fronteira e atravessadas por questões sexuais, étnicas, culturais, sociais, religiosas, entre outras que apresentam implicações na construção de novas identidades da mulher professora primária. Enfim, uma recolocação da mulher, que envolve todo um processo de descolamento, do ponto de partida da identificação feminina dada ou instituída para o processo de construção móvel, ambivalente, contraditória de ser mulher do ensino primário, a partir das relações vivenciadas com outros professores e alunos, como sujeitos concretos e partícipes do processo de escolarização.

Nesse campo entrincheirado por relações que perpassam pelo privado e pelo público, o exercício da docência se dá na área de fronteira, entre privado e o público, marcado por embates entre o que é instituído para a sua efetivação, e o processo que se dá a partir do seu exercício efetivo. Nessa efetividade, o exercício contínuo dos enunciados da fala, dos escritos e dos ensaios reflexivos mediados por saberes e realidades cotidianas, abre um leque de possibilidades para os sujeitos do conhecimento, professores e alunos, a partir de processos criativos de saberes, valores, normas, condutas sociais, morais e ideológicos presentes no cenário sociocultural, que envolvem os sujeitos epistêmicos. Um processo dinâmico e contraditório que envolve então, o (re)ver e o (re)avaliar de posições e avaliações sobre os sujeitos fronteiriços.

Ao mirar a experiência feminina no magistério primário contemplamos no desencadear do ensino-aprendizagem, um processo contínuo de formação e produção de saberes, que ao longo dos anos transformaram a escola e a sala de aula em lócus construtor de "identidades móveis, descentradas, cambiantes e flexíveis", ao situar a professora primária num "entre-lugar", intersticial e transitório, que se conforma pelos fluidos do poder tradicional, conservador, como também pelas influências das mudanças vivenciadas que sinalizam o novo e que passaram a impactar e abrir este espaço para novas representações dos sujeitos do processo escolar, pelas possibilidades de ser, estar e produzir. Neste trânsito entre 
permanências e mudanças, surgem diferentes maneiras de ser e atuar, emergindo a multiplicidade de sujeitos professores e professoras que avançaram para além da sala de aula e, tornaram-se reconhecidos em outras áreas deatuação.

A conformação de outro lugar é resultante das experiências vivenciadas na fronteira e atravessadas por questões sexuais, étnicas, culturais, sociais, religiosas, entre outras que apresentam implicações na construção de novas identidades da mulher professora primária. Enfim, uma recolocação da mulher, que envolve todo um processo de descolamento, do ponto de partida da identificação feminina dada ou instituída para o processo de construção móvel, ambivalente, contraditória de ser mulher do ensino primário, a partir das relações vivenciadas com outros professores e alunos, como sujeitos concretos e partícipes do processo de escolarização.

Nesse campo de relações sociais que perpassam pelo privado e pelo público, o exercício da docência ocorre como espaço de fronteira, entre privado e o público, marcado por embates entre o que é instituído para a sua efetivação e, a emergência de processos que se instituem a partir do seu exercício efetivo. Nessa efetividade, o exercício contínuo dos enunciados da fala, dos escritos e dos ensaios reflexivos mediados por saberes e realidades cotidianas, abre um leque de possibilidades para os sujeitos do conhecimento, professores e alunos, a partir de processos criativos de saberes, valores, normas, condutas sociais, morais e ideológicos presentes no cenário sociocultural, que envolvem os sujeitos epistêmicos. Considerando-se que a experiência na docência desencadeada pelo ensino-aprendizagem é marcada pela contínua produção de sabers que tendem a gerar mudanças no fazer pedagogic, na escola e na dinâmica da sala de aula; com possibilidades de promover a construção de identidades móveis, descentradas, cambiantes e flexíveis dos sujeitos situados nesse espaço "entre-lugar" ou intersticial e transitório, movido pelos fluidos do poder tradicional, conservador, como também pelas influências das mudanças vivenciadas, que sinalizam o novo e que passam a impactar e abrir este espaço para novas representações dos sujeitos; pelas novas possibilidades de ser. Neste trânsito entre permanências e mudanças surgem diferentes maneiras de ser e atuar e o emergir da multiplicidade de sujeitos como professores e professoras que avançaram para além da sala de aula e tornaram-se reconhecidos em outras áreas de produção ou atuação.

O campo da literatura e da poesia tornaram-se campos de expressão cultural, do pensamento e da escrita de muitas professoras, que se apropriaram desses espaços como canal para a escrita de si, dos outros e do mundo. Outras professoras produziram textos ou livros ou cartilhas e livros didáticos para o campo da educação, outras professoras se destacaram pelo 
engajamento social e ou político; o que demonstra todo um processo de desconstrução de si, e das demais pessoas sobre o ideário de inferioridade intelectual da mulher professora primária.

Parafraseando Almeida (1998), a mulher não apenas se tornou somente sexo dominante no magistério primário, mas nesta profissão do "possível”. A mulher professora desenvolveu uma "paixão pelo possível" profissional, pelo empenho, pelo esforço e pelo apreender contínuo, se não a maioria, mas percentual significativo de mulheres do ensino primário fez a diferença no exercício da docência e alcançaram o reconhecimento público como educadoras, e além de educadoras, alcançaram também o reconhecimento intelectual. 


\section{TRANSITANDO PELOS CAMINHOS DA HISTÓRIA CULTURAL: PORTE TEÓRICO-METODOLÓGICO}

\subsection{O SUJEITO-OBJETO SOB A PERSPECTIVA DA NOVA HISTÓRIACULTURAL}

A eleição do pensamento educacional e a trajetória da professora Ester Nunes Bibas como objeto investigativo nos encaminhou para uma pesquisa acadêmica com vistas à construção de uma narrativa biográfica intelectual desta educadora paraense. Nesta direção, a presente tese traz como questão norteadora para a produção historiográfica no campo da educação: Que lugar ocupa/ou a educadora Ester Nunes Bibas e sua produção didáticopedagógica no contexto educacional do Pará? Considerando a hipótese de que esta educadora assumiu lugar de destaque da educação pública no Estado do Pará, ao longo de sua trajetória como professora e escritora no seu tempo-lugar.

Em busca de resposta a essa questão norteadora, todo o processo investigativo se direcionou para a busca de referências bibliográficas, fontes, fatos, relatos e pistas para a apreensão da trajetória desta educadora, assim como, o pensamento educacional, mediante análises das enunciações presentes nos discursos expressos nos livros didáticos de autoria de Ester Nunes Bibas, intitulados "Páginas Brasileiras", livros que se constituem em uma coletânea escolar composta por 05 livros didáticos direcionados ao ensino-aprendizagem do primeiro ao quinto ano do ensino primário, publicados e reeditados pela editora do Brasil entre as décadas de 1950 e1960.

A temática abordada nesta tese situa e problematiza a contribuição da mulher na educação, enfatizando-se de maneira particular, a produção intelectual de Ester Nunes Bibas no cenário educacional paraense. Assim, a tese se delineia a partir das vivências, dos saberes e das proposições didático-pedagógicas, que expressam experiências e as contribuições educacionais desta professor normalista.

O pensamento pedagógico da professora normalista Ester Nunes Bibas materializa-se nos discursos expressos nos textos de sua autoria e em textos selecionados de autores paraenses e nacionais que traduzem os aspectos epistêmicos no campo didático-pedagógico, assim como, por conhecimentos que foram sendo construídos ao longo da trajetória desta educadora. Experiências que foram sendo vivenciadas, apropriadas e defendidas como balizadores das práticas e do ensino docente. Como sabers didático-pedagógicos que matizam sua escrita impressa na coletânea escolar que circulou nas escolas de Belém e adentrou nas escolas mais distantes do estado e, dessa forma, influenciou na construção do saber escolar e o 
do fazer didático de professores e alunos de sua geração.

A tese traz como propósito a produção de uma narrativa histórica acerca da trajetória de Ester Nunes Bibas enquanto mulher, professora e escritora de livros didáticos para a educação primária no estado do Pará; constituindo-se então, numa narrativa histórica mediada pelo gênero biográfico com ênfase à apreensão da intelectualidade que permeia a produção didático-pedagógica, advinda das experiências e saberes escolares, que outorgam a essa mulher professora- escritora, um lugar de importância e de reconhecimento no campo educacional no estado do Pará.

Neste direcionamento, a tese estabelece interconexões com diferentes olhares historiográficos, em especial, pelo cruzamento da História cultural, intelectual, biográfica e com aproximações com a história da educação. Se caracterizando como estudo acadêmico que transita pelas fronteiras da Nova História Cultural, enquanto caminho metodológico e aporte epistêmico que subsidiam a compreensão do sujeito-objeto, seu contexto, sua formação, sua intelectualidade para a efetivação de um registro de uma história singular pela visibilidade do percurso educacional, profissional e intelectual desta professora paraense.

Todo o processo investigativo e de análise da produção cultural de Ester Nunes Bibas se circunscreve metodologicamente na perspectiva da análise de discurso bakhtiniana, enquanto instrumental que oportuniza conhecer nos textos escritos de Ester Nunes o "dito e o não dito" a voz dos diferentes sujeitos que estabelecem uma relação dialógica com o pensamento pedagógico desta educadora-escritora e sua localização na política educacional neste momento de produção e circulação desses saberes.

O campo historiográfico desde o século XVIII e XIX reconhece a "gênese e o desenvolvimento de diferentes expressões associados à formação do grupo de letrados e intelectuais" (GASPARELLO, 2009, p.48). Nesse campo, a História tem referenciado a escrita de homens de letras, entre os quais, a figura do professor intelectual, produtor de livros didáticos. Nesse campo de produção, somente, se verifica o reconhecimento da mulher professora normalista, escritora de obras didáticas nas décadas recentes, a partir de pesquisas relacionadas a história do livro e da produção da produção de livros escolares no Brasil.

Neste circuito investigativo, o livro escolar ou didático, enquanto suporte didáticopedagógico é elemento integrante da cultura material escolar. O Estudo sobre o livro e seu autor vem subsidiando pesquisas acadêmicas que estabelecem interconexões entre produção intelectual e o campo da educação, com ênfase aos estudos investigativos de professoresescritores enquanto intelectuais do campo educacional.

Certeau (2006) afirma que a construção e a representação do intelectual são resultantes 
da prática da escrita, enquanto "exercício compreensivo, explicativo e documentado" e nesta práxis constitutiva compara o intelectual a um 'místico' por ser movido pela busca contínua, e por não satisfazer-se se empenha no ato de criar e recriar pelo pensar e escrever como caminho a ser percorrido para a produção de um texto, de um livro, de um argumento, no qual expressa seu olhar que transcreve seu pensamento. Uma intelectualidade que revela e é revelada pelo potencial de criação, pelo escrever, pelo saber produzido e pela renovação do pensar e do escrever.

Todo o processo de construção desta produção escrita biográfica intelectual da professora Ester Nunes Bibas transita pela perspectiva da Nova História Cultural em seus diferentes campos, entre eles, a história intelectual, biográfica e, análise de discursos de sujeitos produtores culturais protagonistas no campo da educação como referencial epistêmico e instrumental para a análise de práticas culturais de sujeitos que apresentam concepções e práticas para o campo educacional, observando-se o estudo de "vidas concretas vividas", demarcadas pelas apropriações culturais de um dado período histórico para a construção de uma narrativa histórica, biográfica e intelectual, ao tratar do “ individual, da trajetória de uma dada vida, específica e concreta" (CARINO, 2000, p. 163).

A partir deste viés historiográfico, a tese se subsidiará nas contribuições de autores atuante no âmbitoda história cultural:Chartier (1992, 1998, 2002, 2009); Barros (2007, 2009); Dosse (2004); Burcke (1997, 2002, 2007); François; No campo da Mulher: Perrot (2007); Del Priore (1997); Scott (1998), Spvak (2010); Alambert (2004); Do campo da história intelectual, nos aportamos em Sirinelli (2003); Said (1992). Dos estudos biográficos, Ferrarotti (2001). Do campo do gênero do discurso, as contribuições de Bakhtin (1997, 2009), como escritor no âmbito da filosofia da linguagem, destacando-se os conceitos de autor, autoria, significação, polifonia, dialogismo e gênero do discurso nas análises textuais, que insere a voz, a palavra e a escrita nos processos de interação social entre sujeitos esociedades.

A História Cultural ganha destaque nas últimas décadas do século XX e está associada a mudanças verificadas no campo historiográfico desde o início desse século. É considerada como vertente historiográfica interdisciplinar pelo alargamento de suasfronteiras, por abarcar diferentes abordagens, enfoques, possibilidades e caminhos investigativos. Neste percurso, embora se centralizando na questão cultural, o faz de forma transversal pela incorporação da noção de "poder" dos aspectos sociais e pelas redefinições do conceito de "cultura", a partir de um olhar polissêmico que atribui diferentes sentidos e significados. Traz em suas abordagens conotações bem diversas das noções de cultura pensadas e defendidas pelos historiadores do século XIX. A renovação conceitual se volta para a compreensão do mundo 
cultural enquanto reflexo da vida cotidiana do pensar e do atuar de sujeitos, diante dos afazeres da vida no dia a dia. No contexto da História Cultural, a valorização de "outras histórias" como experiências de outros sujeitos, então excluídos da história.

\begin{abstract}
Abrir trilhas inovadoras, desimpedidas de cadeias sistêmicas e de explicações causais, (cria-se) possibilidades de articulação e inter-relação, (recupera-se) diferentes verdades e sensações, (ao) promover a descentralização dos sujeitos históricos e a descoberta das histórias de gente sem história (SANTOS, 2012, p. 7, apud MATOS, 2000, p.23).
\end{abstract}

Neste contexto cultural, novos sujeitos são trazidos para o centro dos estudos históricos, como o grupo familiar, camponeses, operários, mulheres e as apreensões dos significados dos acontecimentos, dos gestos nas experiências cotidianas pela valorização da atuação de indivíduos e grupos. Deslocam-se os estudos históricos do campo das instituições públicas, das ações do Estado para a esfera da vida privada e se institui "A história em migalhas", segundo a concepção de Dosse (1992), ao enfatizar as ações centradas na atuação protagonista de indivíduos.

\footnotetext{
Por meio de suas experiências de vida, elaboram seu modo de vida, sua cultura e sua cotidianidade em parceria com os demais indivíduos. Ao existir, qualquer indivíduo já está automaticamente produzindo cultura, sem que para isto seja preciso ser um artista, um intelectual ou um artesão. A própria linguagem e as práticas discursivas que constituem a substância da vida social, embasam esta noção mais ampla de cultura (BARROS, 2003, p. 146).
}

A existência humana em sua cotidianidade está imersa em relações imbricadas, e no processo de construção do social, em que a essencialidade do humano emerge sob o tom da complexidade, do contraditório e da ambivalência da realidade social. O homem se situa nesse contexto diverso como produtor cultural do mundo em que vive e de si mesmo através de suas práticas sociais cotidianas. $\mathrm{O}$ cotidiano então, se revela como campo emaranhado de possibilidades diante da diversidade social e cultural funcionando como uma janela que espreita a vida social e revela a intimidade, a subjetividade, as ações e atuações que marcam o dia a dia de indivíduos e grupos. Assim, tornando-se espaço objetivo e perceptível da produção social, cultural, econômica e, tornando-se espaço onde se dá a ntrodução, a vivência ou a inovação de valores e costumes ordenadores da vidasocietária.

O cotidiano é aqui concebido como expressão da dinâmica da vida do dia a dia e assim, como referência à vida de todos os dias e de todos os homens de um determinado tempo/lugar, referindo-se as atividades rotineiras, banais, que expressam e fundamentam um modo de existência. Agnes Heller afirma que não há "vida humana sem cotidiano e 
cotidianidade $[. .$.$] o cotidiano constitui-se referência de um homem real numa sociedade real".$ (Heller, 1972, p.18). Uma conotação da vida social que está associada às atividades humanas e as experiências construídas epartilhadas.

A História Cultural emerge no bojo da constituição da Nova História, relacionada a atuação historiográfica na Terceira Geração dos Annales. A concepção da Nova História surge a partir da publicação de uma coletânea de ensaios do historiador Jacques Le Goff (1990), ao incluir em seus textos a análise de novos problemas, novas abordagens e objetos para o campo historiográfico, como postura epistemológica em oposição a história tradicional. A Nova História traz o enfoque multidisciplinar, estendendo as fronteiras do campo histórico. Rompe com o paradigma essencialmente político e se desloca para a análise centrada na "atividade humana" e no cotidiano da vida de pessoas comuns. Emergem estudos sobre a infância, a loucura, a morte, os gestos, a feminilidade, a leitura entre outros temas como objetos de estudos, que passam a ser compreendidos como "construções culturais"; temas específicos, se levarmos em consideração o tempo, o espaço e ambiência cultural (BURKE, 2010, p. 112-116).

Uma concepção historiográfica centrada na dimensão social dos fatos, e sua representação é compreendida enquanto processo "social e culturalmente construída." Ao se aproximar do cotidiano dos indivíduos e se deslocar da análise histórica dos grandes homens para os homens comuns ou com menor notoriedade. O que traz para a historiografia, a "História vista de baixo", ou seja, pela valorização da história de "sujeitos excluídos da história”. No plano metodológico, a análise da fala, das opiniões, e das percepções de homens e mulheres, como testemunhos precípuos na constatação de seu passado, de suas experiências vividas ou de outros sujeitos com quem mantém ou manteve proximidade. Sujeitos, até então, excluídos da história tradicional por não se localizarem nas relações dominantes de poder, o que gerava a desconsideração da atuação desses sujeitos. A Nova História, no entanto, passou a considerar a experiência de homens e mulheres, tão ignorados pela historiografia tradicional. Uma abordagem considerada revolucionária trazida pelos associados a Escola dos Annales. A partir de Fevbre, Marc Bloch e pela geração seguinte a Braudel, esta escola trouxe para o campo histórico, na virada do século XIX para o XX, um novo formato de pesquisa e uma nova escrita histórica, trazendo o deslocar das análises históricas então, centradas no econômico para a superestrutura. A História Cultural passou a promover uma escrita histórica marcada pela dimensão sociocultural; fazendo aproximações com as Ciências Sociais, no campo da filosofia, antropologia, psicologia, economia, linguística, cultura popular entre diversos campos. 
Vários autores como Thompson (1960), Williams (1969), Hobsbawn (1988) entre outros historiadores passaram a estabelecer em seus estudos uma inter-relação entre a História Cultural, a História Social e a História Política, como campos afins da Nova História.As pesquisas trouxeram renovação para o campo dos estudos culturais, a partir da visão da escola Inglesa associada ao Marxismo. São autores que estabeleceram outra percepção da relação da infraestrutura e superestrutura, mediante uma renovação epistêmica, ao compreender o mundo da cultura como parte significativa do "modo de produção" e uma atuação interativa entre o mundo da cultura e as estruturas econômicas, sociais e políticas como aspectos essenciais para desvendar a realidade social (BARROS, 2003, 149).

Neste direcionamento, Thompson (1960) em seu livro "Formação da Classe Operária Inglesa", faz uma análise sobre a atuação de sujeitos históricos excluídos e ou explorados pela sociedade do capital, as chamadas "classes oprimidas". Com esta abordagem, este autor passou a ser considerado como primeiro historiador a produzir uma escrita histórica marcada pela "história vista de baixo" pelo enfoque a atuação política de camponeses, operários, caçadores em movimentos reivindicatórios por direitos, considerados então, como grupos pioneiros na formação da classe operária inglesa. Em seus estudos, Thompson, traz contribuições significativas para o campo da História Cultural na medida em que suas pesquisas históricas estabelecem diálogos com o campo da Antropologia e da História Social para compreender as relações de poder e o processo de exclusão social de grupos sociais, trazendo para a cena das análises o "contra-teatro" do poder exercido pelos grupos pobres e excluídos, como forma de contra poder exercitado por esses grupos. Uma apreensãoda realidade social marcada pela "teatralidade do poder" que revela formas de violência simbólicas por parte do Estado e ou parte dos grupos populares num cenário social de disputa e poder que assegura a visibilidade da atuação histórica dos novos sujeitos históricos (Idem).

A dimensão cultural trazida por Thompson está diretamente relacionada ao conceito de "experiência histórica", ponto focal para reflexão, ampliação e renovação do campo do Materialismo Histórico pela vinculação da história cultural à história política. Thompson defende a aproximação do conhecimento histórico com outros saberes para a compreensão do mundo da cultura, pois "sem cultura não há produção, e sem produção não há história." Nesse contexto de escrita histórica, a perspectiva histórica popular, marginal, incomum das classes oprimidas, assim como a valorização dos aspectos culturais expressos em rituais, práticas, discursos e representações são trazidos para o centro dos estudos históricos (Ibidem).

Williams (1969) reelabora o conceito de cultura a partir do pensamento de Lukács, Althusser, Bakhtin e retoma o conceito de hegemonia de Gramsci, propondo uma nova 
abordagem pelo viés do "Materialismo Cultural", enquanto importante contribuição para o campo dos Estudos Culturais. A partir dessa direção seguida por este autor, as definições de Alta Cultura, Cultura de massa, Cultura cultivada, Cultura popular, Cultura como obra de arte, pouco importa, pois para Williams, o conceito de cultura engloba tais definições. Para Williams (1969), a cultura é de todos, mas não é igual para todos. Embora pressuponha a igualdade do ser humano, a vivência numa sociedade capitalista promotora da desigualdade social, pela concentração da propriedade dos meios de produção e de vida que não se vive na sociedade capitalista a igualdade do ser. A desigualdade no campo da propriedade, fora a propriedade pessoal, a desigualdade na propriedade dos meios de vida e de formação que capacite o indivíduo a um saber e a um lugar social que possibilite a igualdade de oportunidades no usufruto dos bens culturais. No entanto, o processo de desigualdade, as contradições e luta entre classes antagônicas mediaram conquistas e as garantias de acesso ao saber e aos bens materiais e imateriais produzidos pela sociedade como garantia da igualdade de oportunidades. Para Williams (1969), os homens que vivem numa mesma sociedade partilham a herança de uma tradição literária e intelectual, que é constantemente examinada a cada flutuação, surgindo então, novos valores e formas resultantes de um processo democrático em sua plenitude. Um processo que implica na ação interativa e comum na produção cultural, que se manifesta nos processos de criação e recriação, ações partilhadas entre sujeitos e nesta dinâmica, a redução de dicotomias absolutas entre a alta cultura, cultura de massa, cultura erudita, cultura popular, pois todas essas definições são constituintes do mundo cultural (TAVARES, 2008, p. 20 apud WILLIAMS, 1969, p. 326).

Nesta reorientação do campo da história, a partir da compreensão e análise de sujeitos excluídos, se observará a ampliação deste campo da história pela incorporação de uma diversidade de temáticas e sujeitos-objetos.

A Nova História passou a se interessar pela diversidade da atividade humana e afastou-se do foco da história tradicional, então centrado na visão das camadas de "cima"; privilegiando-se os fatos e os feitos dos "grandes homens" estadistas, generais e ou "eclesiásticos" para o destaque da "história visto de Baixo" pela valorização do pensamento e da atuação de pessoas comuns. Desta maneira, se constituindo em uma nova forma de escrever a história, agora, pautada na vida cotidiana. Mudanças na abordagem historiográfica que estiveram associadas às contribuições trazidas por Febvre, Marc Bloch e produções da revista dos Annales (1929). As experiências de homens e mulheres que de forma frequente foram excluídos pela escrita histórica, tornaram-se sujeitos centrais neste momento de mudançashistoriográficas. 
Com esse empenho investigativo, Thompson (1965) nos esclarece a cerca dos sujeitosobjetos a serem investigados:

\begin{abstract}
Estou procurando resgatar o pobre descalço, o agricultor ultrapassado, o tecelão do tear manual 'obsoleto', o artesão 'utopista' e até os seguidores enganados de Joanna Southcott, da enorme condescendência da posteridade. Suas habilidades e tradições podem ter-se tornado moribundas. Sua habilidade ao novo industrialismo pode ter-se tornado retrógada. Seus ideais comunitários podem ter-se tornado fantasias. Suas conspirações insurrecionais podem ter-se imprudentes. Mas elas viveram neste período de extrema perturbação social e nós, não (THOMPSON, 1965, p. 12, 13).
\end{abstract}

Nesta perspectiva da "História vista de Baixo", emerge uma nova abordagem do passado, mediante a utilização de fontes que retratam a fala, escritos e a visão de grupos de indivíduos marginalizados pelo campo da História. Na medida em que são ressaltadas as a experiências de homens e mulheres comuns, oportunizando-se a percepção da história do passado diferenciada do olhar e das opiniões trazidas pelas elites. Entretanto, "quanto mais para trás vão os historiadores, buscando reconstruir a experiência das classes sociais inferiores mais restrita se torna a variedade de fontes à sua disposição" (BURKE-SHARPE, 1992, p. 43).

Eric Hobsbawn (1988) observa que, a denominação de história de "pessoas comuns" começa a aparecer a partir dos registros dos movimentos das massas populares, em torno de 1789, e ganha maior expressividade com os movimentos da classe trabalhadora. São estudos históricos que observavam as ideias dos diferentes extratos do mundo cultural, abrindo-se desta forma, as fronteiras para a História cultural.

Neste cenário historiográfico que destaca o engajamento de indivíduos, grupos e populações em movimentos em prol de direitos de cidadania; vistos então, como "novos" sujeitos que interrogam o Estado, a elite, as práticas educacionais, a docência, o pensamento pedagógico e a educação pública. São protagonistas de uma história que a partir de suas experiências formulam propostas, escrevem e registram outros olhares e pensamentos.

A História Cultural apreende os processos de construção social e da atuação humana pela dimensão cultural e nesta perspectiva, uma compreensão do mundo da cultura. Barros (2011) enfatiza a importância dos conceitos de "práticas" e de "representações" trabalhados por Chartier (1999), como categorias estratégicas para o estudo de "objetos culturais".

Sujeitos produtores e os sujeitos receptores culturais, como objetos de pesquisa, (assim como todos) os processos que envolvem a produção e a difusão cultural, os sistemas que dão suporte a esses processos e sujeitos e, por fim, as normas a que conformam as sociedades através da consolidação de seus costumes (BARROS, 2011, p. 38). 
Chartier (1990), em seu livro História Cultural: entre práticas e representações, traz a apreensão da realidade social como processo “construído, pensado e dado a ler" pelas práticas sociais, pela linguagem, pelas escolhas, pelas condutas e pela intelectualidade presente nos processos de produção, enquanto dimensões reveladoras nos processos de construção de representações sobre o mundo social. As representações coletivas estando associadas às ideias, às imagens mentais produzidas por processos subjetivos geram e estruturam as representações do social. No campo da História, as representações são percebidas entre a ideia que representa e aquilo que é representado, numa relação direta entre o "signo visível” e o seu "significado".

Neste contexto de percepção do social, as práticas culturais, em síntese, representam tudo o que é produzido pelo homem são formas de expressão cultural. Este contexto produtor, estando circunscrito ao processo da comunicação, da escrita, da oralidade, dos gestos, da maneira de estar e viver no mundo como expressões das produções culturais e sua recepção no mundosocial.

Um novo contexto, que tem apontado novos caminhos investigativos subsidiados por novas fontes: discursos trazidos por autores, análises, fatos, pensamentos e documentos que trazem a visão de mundo e de acontecimentos bem diverso dos registros oficiais, ou pela ausência desses registros. A busca da oralidade por meio de testemunhos tem sido utilizada como referência de um tempo, de acontecimentos marcantes de uma realidade social, em que os registros escritos não conseguem desvelar a complexidade de fatos que envolvem a experiência humana.

No contexto da Nova História Cultural, Chartier (1999) traz em seus ensaios novos enfoques a partir da percepção do "modo como em diferentes lugares e momentos uma determinada realidade social é construída, pensada, dada a ler.” Nesta percepção ou apreensão do social, o olhar deve ser focalizado nas práticas sociais expressas nessa realidade enquanto elementos construtores dos processos de representação do mundo social, construídos segundo os interesses dos grupos que as forjam. Neste âmbito, os discursos que explicitam as representações não são "neutros"; produzem estratégias, práticas que são apropriadas por diferentes campos do mundo societário; social, político, escolar, entre outros. Considerandose que, as praticas e as produções culturais são percebidas e compreendidas, mediante uma representação que emite sentidos, significados, e que matizam e configuram uma realidade social. O conceito de representação do mundo social assume sentidos diferenciados: Como "rememoração" quando se constrói uma imagem que representa algo ou alguém ausente, 
assumindo o sentido de reconstituição; Como representação simbólica, quanto estabelece uma relação entre um signo, objeto, sujeito e o seu significado. Uma Percepção fundamental para a apropriação do ver, pensar e do apropriar-se de uma realidade diretamente relacionada a compreensão do sujeito e do mundo social em que vive.

Ainda sob o olhar de Chartier (1990), o "modo como em diferentes lugares e momentos uma determinada realidade social é construída, pensada, dada a ler”. A apreensão desta realidade se dará pela percepção das práticas sociais expressas nesta realidade, enquanto elementos construtores dos processos de representação do mundo social, construídos segundo os interesses dos grupos que as forjam. Neste sentido, os discursos que explicitam as representações não são "neutros” produzem estratégias, práticas que são apropriadas por diferentes campos do mundo societário; o social, o político, o escolar entre outros. Considerando-se que as práticas e as produções culturais são percebidas e compreendidas a partir de uma representação que emite sentidos, significados, que matizam e configuram uma realidade social.

As representações mundas socioculturais, apreendidas como "certas", "prováveis", "naturais" e ou instituídas; na realidade são decorrentes do processo de aceite e ou de imposição, mas rodas são resultantes de um processo de construção social, ainda que produzidas pelas relações de subalternização.

Para Darnton (1990), o campo da história Intelectual é concebido como campo historiográfico que abrange diferentes campos historiográficos; perpassando pela "história das ideias (campo filosófico), a história intelectual propriamente dita relacionada ao pensamento intelectual, a história social (ideologias) e a história cultural no âmbito da cultura e mentalidades.

A história Intelectual a presenta uma dimensão multidisciplinar pelos diferentes enfoques abordados, tornando-se tanto campo epistemológico quanto campo metodológico a ser empreendido por diferentes campos do saber: sociológico, educacional, histórico e outros campos que aliados ao interesse de "conhecer, desvendar, desvelar e reconstruir o passado através da mobilização de testemunhos que buscam dar vida à narrativa que se produz" (PANIZZOLO, 2011, p. 79).

Um campo historiográfico que remete para o estudo e a reconstituição da trajetória pessoal, profissional e o pensamento de homens e mulheres. Um campo que se envereda pelos estudos de vida e da intelectualidade de homens e mulheres, a ser traduzido por uma escrita biográfica, observando-se que: “escrever uma biografia significa, pois, narrar uma trajetória compreendida aqui não no senso comum do termo, que a torna sinônimo de caminho, 
percurso, estrada a ser percorrida, tendo sido dada de antemão" (Idem, p. 80).

Gramsci (1970) em relação à condição se ser intelectual, nos aponta uma representação de intelectual atribuída a todos os homens, por considerar que "todos os homens são intelectuais" no sentido de que não existe o não intelectual. Embora também considere que nem todos os homens ocupem uma função de intelectual na sociedade. Mas considera que o poder criativo reprodutor de ideias se faz presente em toda atividade desenvolvida. Além dessa observação de caráter geralista, o autor estabelece a diferença entre os intelectuais orgânicos e os intelectuais tradicionais. Entre os intelectuais tradicionais, este autor denomina como tal, os professores, os religiosos, os sábios, vistos como iluminados e de espírito elevado, situados no seu lugar de status. O intelectual orgânico, por sua vez, tem um papel inverso dos intelectuais tradicionais, ao considerer que sua atuação é decisiva para as mudanças sociais, pois, apresenta como papel principal a "conscientização dos grupos subalternos para o alcance da criticidade", como fator decisivo para uma atuação mais eficaz em direção as mudanças da sociedade.

$\mathrm{Na}$ sociedade moderna, o poder e o saber se apresentam como condicionantes da representação dos homens e de seu lugar numa dada realidade social e em meio às mudanças na trajetória de vida, os intelectuais engajados podem vir assumir posturas tanto conservadoras quanto transformadoras, ainda que, ao longo de sua trajetória e experiências, possam vir assumir posturas bem diferenciadas. O que interfere nesse posicionamento político está relacionado processos de formação intelectual, maturidade, e contexto de pertencimento social, cultural, étnico, político, como fatores que lhe encaminha para a postura de consenso ou deinsurreição.

Said (1992), concebe uma imagem de intelectual atuante, inserido no meio social, e que a busca de conhecimentos se torna necessário, para que este intelectual venha dar conta das relações de poder e de domínio presentes na sociedade. Em geral, é um estudioso engajado com uma causa, que se torna sua bandeira de luta. Para Said, ser intelectual é "pensar e experimentar o mundo da existência". O mundo vivido pela experiência. A experiência designa quem a vivencia pelas suas práticas e seu engajamento. Ainda, como afirma Scott (1998), “a experiência concebida como metáfora de visibilidade, quanto por outro modo que tem o significado como transparente". Na medida em que sua experiência e atuação representam o intelectual e revela quem é este intelectual, seus pensamentos, seus propósitos e seu lugarsocial.

No âmbito da intelectualidade, todo grupo social necessita de intelectuais para legitimação de sua posição de classe, de etnia, de gênero. Neste campo, verificando-se tanto a 
atuação de intelectuais orgânicos, quanto intelectuais tradicionais.

Said (1992), em seus estudos, traz uma definição bem específica do intelectual, não dogmático e autocrítico, ser contrário à obediência. Devendo se situar no combate ao domínio hegemônico do poder. E que seu conhecimento e sua intelectualidade se tornem indispensáveis para a defesa de seus ideais e do inconformismo diante da sociedade em que vive.

Nesse engajamento social e político se aproxima ao conceito de Intelectual de Sirinelli (2003), que considera a trajetória dos intelectuais e sua inserção na sociedade se dá sempre a partir de uma área e de uma atuação específica. Ou seja, de um campo de saber que qualifica sua participação como sujeito atuante. O saber e a sua atuação lhe revestem de uma representação de um intelectual engajado com seu tempo. Se revestindo assim, de um reconhecimento como agente importante na circulação cultural. Fruto de suas vivências e saberes, os intelectuais estabelecem "relações estruturadas de rede que falam de lugares, mais ou menos formais de aprendizagem e de trocas, de laços que se atam, de contatos e de articulações [...] a noção de rede remete ao microcosmo de um grupo particular em que se produz vínculos afetivos”. Em Sirinelli (2003), o conceito de intelectual refere-se a homens e mulheres no exercício da docência estendendo essa representação de intelectuais "aos criadores e mediadores culturais, entre eles, os jornalistas, escritores, professores, eruditos, estadistas e demais produtores e receptores de informações".

Nesse campo diverso de intelectualidades, a história se volta para a valorização de homens e mulheres comuns. A escrita histórica sobre esses sujeitos vem sendo estruturada pelos estudos biográficos. A produção biográfica passou a ser efetivada para além dos grandes intelectuais, ao dar ênfase à produção cultural de intelectuais de menor notoriedade e nesse encaminhamento a emergência de uma escrita histórica que resgate a trajetória dos excluídos ou invisíveis para a História; os “debaixo". Ou seja, a escrita biográfica trouxe para o campo histórico, novas frentes de pesquisas sobre a trajetória e o pensamento de intelectuais de diferentes áreas do conhecimento. E a partir das últimas décadas do século passado, o gênero biográfico intelectual vem ganhando centralidade nas pesquisas históricas, observando-se nesse campo o aumento da produção de estudos biográficos; o que demonstra não somente o retorno deste gênero historiográfico, mas sua valorização, como fonte de produção da escrita da historia.

No entanto, Le Goff (1999), nos chama atenção para o fato de que "escrever biografias não é uma tarefa simples", considerando as questões teórico-metodológicas nesse processo de construção entre outros questionamentos: 
Do ponto de vista epistemológico, como cuidar da generalização, ou seja, como descobrir a interseção entre a trajetória individual e a sociedade na qual essa trajetória é percorrida? Observando a questão de outro ponto de vista: como estabelecer o contorno do individual, isolando-o e, ao mesmo tempo inserindo-o no coletivo? (CARINO, 2000, p. 163).

Questões que vêm sendo dirimidas, na medida em que o gênero biográfico passou a ser subsidiado pelas demais vertentes ou abordagens historiográficas, e em especial nos fundamentos das ciências humanas. Dimensão multidisciplinar que embasa a narrativa biográfica para uma produção histórica de forma coerente e significativa acerca de uma pessoa num dado período histórico. Uma conduta investigativa aponta paro o historicizar dos fatos e entender o sujeito, sua trajetória, seus contextos e contradições. Enfatizando-se nessa abordagem uma análise "dialética entre acontecimentos, conjunturas, estruturas, elites e massas, indivíduos e grupos, palavra e ação, de modo a não simplificar a trajetória numa visão linear ou teleológica" (ROIZ, 2012, p. 139).

A Nova História Cultural passou a explorar os estudos biográficos como instrumento de análise da prática cultural dos indivíduos, pela apreensão de "vidas concretas vividas" demarcadas pelas apropriações culturais de um dado período histórico.

$\mathrm{Na}$ construção da trajetória de Ester Nunes Bibas, a narrativa biográfica se tornou, técnica de abordagem para esta escrita historiográfica, por tratar-se de uma dada vida, específica e concreta. Como processo inicial para se conhecer este sujeito, sua atuação, sua fala, seus escritos e seu pensamento intelectual, como caminho investigativo para o desvelar o lugar de Ester Nunes Bibas no cenário educacional do estado do Pará.

Todo o processo de construção do estudo biográfico intelectual sobre a trajetória e produção didático pedagógica da Professora Ester Nunes Bibas remete ao estudo de ideias e ou "inteligências" que demarcam a atuação profissional e intelectual deste sujeito mulher, professora e escritora do campo educacional. Um processo construído ao longo deuma trajetória histórica. Uma caminhada profissional que se alinha à um tempo, à uma cultura e a um pensar sobre os processos de educação, diretamente relacionados á um grupo de intelectuais, como representantes de uma geração de pensadores que traduzem o pensamento e o fazer pedagógico de uma época. O nosso sujeito-objeto de estudo, Ester Nunes Bibas é contemporânea de mulheres com grande inserção na Educação Paraense e no âmbito da literatura, entre elas: a professora Hilda Vieira, Poranga Jucá, Antonieta Serra Freire, Palmira Lins de Carvalho, Graziela MouraRibeiro.

No cenário da história biográfica, os professores primários se inserem como 
intelectuais específicos do campo educacional e da cultura escolar com "saberes e práticas expressas em suas produções escritas. Nesse contexto de produção, Carlota Boto (2003) afirma que os educadores-escritores são vistos como guardiões de valores e com saberes específicos voltados para o processo de escolarização. Intelectuais comum a singular importância para a compreensão da educação, da atuação das escolas, dos processos docentes e da aprendizagem. Contribuições, ainda que localizadas expressam concepção de educação que estabelecem proximidades com os processos de formação de professores e da política educacional nacional e local vigente.

O cenário de produção imerso em práticas discursivas reveladoras da vida social, enquanto apreensão da cultura que cimenta todas as relações sociais entre produtores e receptores de bens culturais. Os objetos culturais são construídos por mediações entre práticas e representações que encarnam maneiras de ver, de fazer e de pensar o mundo.

O livro no âmbito da educação escrito por educadores, se tornou ponto referencial para se conhecer quem escreve, considerando-se que os escritos não são desencarnados e revelam muito do seu escritor, do seu pensamento e dos conhecimentos neles veiculados. Se constituindo modelo e diretriz da prática de ensino, carregado de sentidos e posturas ideológicas em relação à concepção de educação, às práticas didático-pedagógicas.

Os textos e exercícios presentes nos livros didáticos se tornam elementos mediadores dos processos de escolarização e na construção dos processos de identidade de professores e alunos; por disseminarem valores, normas, condutas e posturas diante da educação, da escola, do ensino, ou seja, os livros didáticos disseminam e consolidam a cultura escolar.

Neste contexto educacional, o professor-escritor, enquanto intelectual, assume um papel de "ator social", com a função de fazer circular saberes que revelam o mundo social, como representações reais, concretas da sociedade. E o livro se reveste de uma linguagem, de um discurso que comunica uma mensagem com intencionalidade, com significados simbólicos e com poder de instituir ou alterar normatizações sociais entre produtores e receptores culturais.

Segundo Barros (2003), nos processos de construção cultural emerge diversas alternativas diante de um variado repertório de possibilidades. Nesta construção, precisamos perceber os discursos, as relações dialógicas em relação às posições e contraposições diante do que é enunciado pelos textos dos livros didáticos, obras de professores para professores e alunos. 


\subsection{ANÁLISE DE GÊNERO DE DISCURSO SOB A PERSPECTIVE BAKHTINIANA}

\subsubsection{Bakhtin e a filosofia da linguagem: campo referencial para análise do discurso}

Mikhail Bakhtin é considerado como um dos pensadores mais destacados no campo da linguagem, literatura e arte. Ao longo de sua trajetória dedicou-se a proposição de conceitos e categorias que substanciaram a formulação de uma Filosofia Materialista da Linguagem. É formulador de uma nova epistemologia em contraposição às correntes de pensamento vigentes nas primeiras décadas do século XX. Constituindo-se em uma proposição que parte e se focaliza em análises discursivas cotidianas, artísticas, filosóficas, científicas e institucionais. Neste contexto, está atrelada ao pensamento e às proposições e reflexões de intelectuais da linguagem, da Filosofia, Literatura, Arte e outros campos do conhecimento. Profissionais, reconhecidos posteriormente como o "Círculo de Bakhtin".

Suas análises partem da concepção da linguagem como processo interativo, mediado por relações dialógicas. Postura radicalmente contrária à concepção da linguagem como sistema autônomo e ou como sistema referencial da língua, palavras e estruturas gramaticais. A linguagem para Bakhtin se define como processo enunciador da vida concreta, que ganha sentido na comunicação efetivas entre o "eu e o 'outro", situados como autor/criador e ouvinte, num contexto de enunciação, no qual, a língua se torna referência dos locutores: falantes/escritores e interlocutores/ouvintes, que também são enunciadores, pois estão interligados num mesmo contexto interativo decomunicação.

Nesse processo de interação, os enunciadores concretos se constroem e se reproduzem num efetivo processo de comunicação, referendados pelo contexto social, cultural, histórico e ideológico. Um espaço social referenciado por tramas e teias sociais que envolvem, conforma e ou revelam situações de oposição entre locutor e interlocutor, que se expressam pela via verbal ou não verbal, como processo dinâmico, revelador dos enunciados presentes numa cena de comunicação.

No contexto dos discursos, a palavra enunciada seleciona, posiciona os sujeitos falantes pela formulação de mensagens, que compreendidas pelos ouvintes, as interpreta e as respondem com outros enunciados de forma verbal, por gestos ou porpensamentos.

Mikhail Bakhtin é contemporâneo do pensador e escritor Karl Marx (1818 - 1883), se vincula aos aspectos filosóficos do marxismo e, elege como base de sua proposição a "vida vivida" e sua relação direta na constituição do sujeito em meio aos processos de consciência de si e dos outros. As relações entre sujeitos revelam aspectos da vida social, cultural, política 
e das forças ideológicas que classificam e posicionam os indivíduos segundo os padrões dominantes. Bakhtin desenvolveu uma teoria inovadora que traduz a constituição dos indivíduos pelos discursos literários e pela cultura e assim, desbravadora da vida sociocultural. Sua proposição está expressa no "conjunto de sua obra (que) se caracteriza pela interdisciplinaridade, a partir de uma abordagem dialética de questões relacionadas à filosofia, linguística, psicanálise, teologia, poética, teoria social e literatura” (MAGALHÂES, 2007, p. 210).

A análise bakhtiniana está pautada na estética verbal e na compreensão de um texto falado ou escrito. Diante do texto ou fala, o pressuposto de uma responsividade e um posicionamento valorativo do falante, do escritor, do leitor ou ouvinte, expressas por atitudes de concordância, de recriação, exaltação ou negação como resposta no processo interativo de comunicação, notadamente, marcado por uma relação dialógica entre enunciadores.

Para Forin (2006), o dialogismo presente numa cena de comunicação revela diferentes sentidos e podem estar presentes em vozes ocultas no enunciado, considerando-se que todo enunciado é uma resposta a outro texto, ainda que não expresso no discurso; mas percebida a partir de vozes de outros enunciadores. Podendo-se perceber as vozes dos interlocutores de forma aberta ou separado do discurso emissor. O dialogismo se faz presente num discurso pela ação do individuo, mediante resposta às diversas vozes presentes. São importantes observações para se perceber como os discursos se constituem em meio às tramas do contexto social. Ou seja, perceber a partir da linguagem, as interconexões com a vida social. Bakhtin trazem a tona uma proposição filosófica que leva em consideração o acontecimento real, singular e historicamentesituado.

\subsubsection{A Criação Verbal e o Gênero doDiscurso}

A análise e a Teoria do Discurso no pensamento bakhtiniano expressam aspectos teórico-metodológicos diante da análise de textos e discursos, como caminho para a compreensão da realidade sociocultural, embora não se constitua uma perspectiva fechada, a perspectiva bakhtiniana trouxe contribuições para os estudos da linguagem, linguística e ciências humanas. Bakhtin inaugura uma análise e/ou uma teoria dialógica do discurso a partir do campo filosófico da linguagem para compreender a vida cotidiana. Sua formulação de gênero de discurso tornou-se referência para a pesquisa investigative no campo das Ciências Sociais.

Nesse contexto propositivo de análise de discurso BRAIT (2014), assevera que: 
Sem querer (e sem poder) estabelecer uma definição fechada do que seria essa análise/ teoria dialógica do discurso, uma vez que esse fechamento significaria uma contradição em relação aos termos que a postulam, é possível experimentar sem embasamento constitutivo, ou seja, a indissolúvel relação existente entre língua, linguagem, história e sujeitos que instaura os estudos da linguagem como lugares de produção de conhecimento de forma comprometida, responsável, e não apenas como procedimento submetido a teorias e metodologias dominantes em determinados espaços [...] diz respeito a uma concepção de linguagem, de construção e produção e sentidos necessariamente apoiados nas relações discursivas empreendidas por sujeitos historicamente situados (p. 10).

A expressão da linguagem aparece como base na percepção estética do social e do cultural. Sua proposição se constitui em uma atividade criativa, ética e estética sob o foco da realidade social. A estética tem se tornado objeto de estudo de inúmeros filósofos e nos estudos bakhtinianos se tornou temática central.

Falar da ética e da estética em Bakhtin:

É evocar o que se pode considerar a base de tudo [...] é evocar, de um lado, a ressignificação que ele propõe dessas categorias e, de outro, sua instância na integração arquitetônica dessas dimensões do humano na unidade da responsabilidade que é a tarefa de cada sujeito humano (SOBRAL, 2013, p. 103).

A linguagem se situa como expressão da integridade concreta e viva de um ser que fala, ouve e se posiciona no discurso. O discurso ou as manifestações discursivas estão situados como metalinguística por se localizar para além de uma linguística "abstrata" e distanciada da concretude da vida vivida. Assim, o termo e ou conceito discurso apresenta-se como objeto complexo por dar conta das relações dialógicas entre o falante e o ouvinte, que também é falante. O que insere a abordagem do discurso a partir de um ponto de vista interativo interno e externo, como dados inerentes do processo de linguagem. Pois, em Bakhtin, a linguagem:

Leva em conta, portanto, as particularidades discursivas que apontam para contextos mais amplos, para um extralinguístico aí incluída (e) o trabalho metodológico, analítico e interpretativo com textos/discursos se dá - como se pode observar nessa proposta de criação de uma nova disciplina ou conjunto de disciplinas - herdando da linguística a possibilidade de esmiuçar campos semânticos, descrever e interpretar marcos earticulações enunciativos que caracterizam o(s) discurso(s) e indicam sua heterogeneidade constitutiva, assim como, as dos sujeitos aí instalados. (SOBRAL, 2013, p. 13).

Os estudos bakhtinianos, se pautam na individualidade, enquanto constructo advindo das relações sociais vividas pelo sujeito e não resultante do processo de "assujeitamento" ou submissão do indivíduo ao social, levando-se em consideração que a criação ética e estética 
pelo indivíduo resulta da criação de valores, de sentidos e significados inerentes ao ato criador do agir concreto do indivíduo, do sujeito na esfera produtiva de enunciados e discursos.

Assim, para o Círculo de Bakhtin, as categorias como "percepção", "pensamento" e/ou “consciência," não estão fora da vivência concreta dos sujeitos, ou seja, estão situados na sociedade e na história e não num plano essencialmente humano idealista. O que torna o ato humano como atividade autoral e científica, produzido num contexto interativo, enquanto atos “éticos, responsáveis e responsivos". O processo criador torna o indivíduo como um ser responsável em todos os momentos da totalidade da vida. Assim sendo, a criação e a responsabilidade obrigam o sujeito a aproximar da "vida e arte", da "arte e vida" para o alcance de um posicionamento filosófico, mediante um processo de aproximação entre o mundo artístico e o mundo real vivido que interliga o "homem, ciência, arte e vida".

\subsection{PERCURSOS INVESTIGATIVOS}

Ao tratarmos de uma proposição acadêmica que tenciona investigar e compreender a atuação da professora paraense Ester Nunes Bibas, a partir da trajetória como docente e de sua produção didático-pedagógica expressa nos livros didáticos "Paginas Brasileiras", a presente tese reporta-se para o campo dos estudos e pesquisas voltados para a visibilidade da mulher professora com produção intelectual impressa no campo da educação.

Entre as décadas de "1950 e 1960", Ester Nunes Bibas produz a coletânea didática Páginas Brasileiras, voltada para o ensino primário no estado do Pará. Além desta produção educacional, a referida professora publicou no campo da poesia o livro "Rimas do Coração" em 1958, o que demonstra a competência desta professora com a escrita. Ao publicar livros didáticos, a autora traz para o campo da educação uma nova representação de mulher "professora e intelectual” no cenário educacional do estado do Pará.

Todo caminho investigativo deste estudo acadêmico se pauta nos aportes teóricometodológicos da Nova História Cultural em suas diferentes vertentes historiográficas, em especial perpassando pela história da mulher, estudos biográficos, história intelectual e a história da educação, enquanto olhares historiográficos que possibilitam o estudo, a análise e a compreensão do sujeito mulher Ester Nunes Bibas, como professora e escritora do ensino primário no cenário educacional paraense.

Para Barthes (1975), o professor se reveste da condição de intelectual quando além da função de transmitir saberes "escreve um livro". Assim, a elaboração de textos, argumentos ou de um livro assegura ao professor a autoria de uma produção textual, que lhe atribui ao 
escritor o reconhecimento intelectual. Esta concepção de intelectual se aproxima da concepção de Gramsci (2004), ao referendar como intelectuais tradicionais indivíduos vinculados a uma categoria profissional ligada à produção, à cultura e à docência. Entre estes se situam os professores, os religiosos, os sábios, os jornalistas, enquanto criadores e mediadores culturais em seus campos específicos de atuaçãoprofissional.

Todo o encaminhamento da pesquisa perpassa pela trajetória pessoal, profissional e atuação como docente intelectual e, seus percursos transitados no sentido de se perceber a trajetória desta professora imersa no cenário sociocultural da cidade de Belém e do estado do Pará, como contexto demarcador da história da vida, da docência e das escrituras desta professora e da representação da mulher paraense, da professora primária e escritora do campo daeducação.

São referencias que localizam no campo educacional o fazer docente, as práticas educativas, a concepção da educação, o papel da escola e os deveres do aluno num momento histórico demarcado pela valorização da pátria e do patriotismo como fundamento de exaltação da nação brasileira.

Todo o processo investigativo se direciona para a produção biográfica intelectual de Ester Nunes Bibas com ênfase à compreensão de seu pensamento educacional presente livros didáticos Páginas Brasileiras, que traduzem seus ditos, seus referendos, seu pensar a respeito da vida cotidiana, das práticas docentes e dos processos ensino-aprendizagem. E a partir da trajetória singular de Ester Nunes Bibas e de seu pensamento educacional, apreender os ideários que subsidiavam a educação nacional e paraense, seus aportes epistêmicos e didáticos que normatizavam as práticas de professores e processos ensino-aprendizagem, e os conteúdos disciplinares que demarcavam o saber escolar nestemomento.

Chartier (2002) nos orienta a compreender como uma realidade social localizada é construída, pensada e dada a ler. Assim para apreender o contexto educacional paraense, a partir da trajetória e do pensamento de Ester Bibas, se tornar necessário compreender este cenário educacional como uma dimensão de uma realidade social pensada e construída por um conjunto de práticas sociais que medeiam todo processo de representação desta realidade social que é dada a ler pelos discursos que retratam a representação deste lugarsocial.

A questão: Que Lugar ocupa a professora Ester Nunes Bibas e sua produção didáticopedagógica "Páginas Brasileiras" no cenário educacional do estado do Pará? Apresentou-se como direção a ser mirada, como norte para os caminhos investigativos e busca de fatos e referências documentais reveladores da trajetória desta professora paraense e seu pensamento educacional; que por sua vez, possibilitaram a produção de uma biografia intelectual desta 
educadora, considerando-se que Ester Nunes Bibas se constituiu um sujeito que "fala" e revela seu falar, seu pensar por seus escritos impressos. O pensamento educacional presente em seus escritos recoloca o lugar de mulher professora do magistério primário para um lugar mais ampliado de professora, escritora e intelectual no campo da educação. Expressando-se então como uma trajetória transgressora às imposições do cenário social paraense demarcado por valores, discursos e padrões culturais patriarcais que desautorizavam o transitar das mulheres do espaço privado para o espaço público. Assim, por muito tempo, o magistério e o espaço de sala de aula, referendaram o exercício profissional reconhecido como lugar social da mulher, a partir de um modelo de mulher idealizado, socialmente subalterna, submissa e apagada no circuito no lar e no espaço da sala de aula comoprofessora.

Ester Nunes Bibas se constituiu professora e escritora, a partir do lócus profissionail, o magistério primário, enquanto lugar de vivências e experiências. Neste espaço tornou-se sujeito produtor de saberes e de práticas didático-pedagógicas endereçadas aos professores e alunos das escolas primárias paraenses.

Neste contexto de produção cultural desta educadora, o seu pensar educacional interferiu no fazer pedagógico de professores e de alunos do ensino primário no estado do Pará. Entretanto, a condição invisibilidade em que se encontra a trajetória e sua coletânea didática na atualidade, impôs uma pesquisa investigativa partindo da questão norteara para a busca de fontes escritas, documentais, vestígios, e relatos de pessoas que conviveram com a professora Ester Nunes Bibas. As Informações e referências localizadas, até então, revelam-se fragmentadas e dispersas, pontuais, mas sinalizam rastros significativos para a construção da trajetória desta professora, ainda que marcada pela incompletude, assim como , a localização de dois exemplares da coletânea Paginas Brasileiras, nos possibilitarão, a realização de um estudo a partir da perspectiva de análise discursiva de seus escritos didáticos, com vistas à compreensão do pensamento intelectual desta autora expressos nos livros "Paginas Brasileiras", a partir do olhar de que, o sujeito que fala, e escreve, ainda que na condição de invisibilidade "não se pode apagar seu registro" (CALDAS, 2013, p. 11).

Seguindo este direcionamento, o processo investigativo se pauta em três eixos centrais:

Primeiro Eixo: Vida e Caminhos Transitados por Ester NunesBibas:

a) Busca de Registros escritos, documentos, Informações e Escritos Autobiográficos da professor-escritora;

b) Relatos de familiares e amigos: dados da memória familiar em comparação com as informações localizadas em documentos e o contexto históricocultual. 
Segundo Eixo: Levantamento de referências bibliográficas e ProduçõesAcadêmicas

c) Referências Bibliográficas.

d) Teses, Dissertações, artigos.

Bancos de Tese, Dissertações e Artigos: CAPES, UNICAMP, UFMG, PUC-RIO, USP- São Paulo, UFPA, UFMA.

e) Descritores utilizados na pesquisa.

\begin{tabular}{|l|l|}
\hline História cultural & Mulher e Magistério \\
\hline História da mulher & Educação e emancipação \\
\hline História da educação & Feminização do Magistério \\
\hline História Intelectual & A Educação no estado do Pará \\
\hline Estudos biográficos & Professores, escritores e intelectuais. \\
\hline Sujeitos esquecidos pela história & $\begin{array}{l}\text { Professoras escritoras de livros } \\
\text { didáticos }\end{array}$ \\
\hline Invisibilidade da Mulher & Mulher no contexto Paraense \\
\hline Estudos feministas & História do Livro didático \\
\hline Educação e a Mulher & $\begin{array}{l}\text { Análise discursiva sobre livro } \\
\text { didático. }\end{array}$ \\
\hline
\end{tabular}

Terceiro Eixo: Análise dos livros didáticos "Páginas Brasileiras" sob a perspectiva Material e discursiva.

A análise do pensamento educacional da professora Ester Nunes Bibas, expresso nos livros didáticos de sua autoria, o presente estudo se embasa na concepção linguística a partir da perspectiva de que as relações discursivas são produzidas através das relações dialógicas entre sujeitos situados num mesmo cenário social, histórico e cultural

Contexto em que se circunscrevem os enunciados discursivos entre sujeitos num evento de comunicação.

Brait (2010) destaca a importância da linguagem e a metalinguística como campo disciplinar fundamental para a compreensão dos sentidos, dos significados que entrecruzam os enunciados discursivos, tornando-se caminhos metodológicos que detalham o sentido da linguagem ao descrever, analisar e reconhecer as "marcas" presentes nos enunciados discursivos que "caracterizam o (s) discurso (s) em heterogeneidade constitutiva, assim como dos sujeitos aí instalados" (BRAIT, 2010, p.13).

a) Corpus da Análise Discursiva: O estudo dos livros didáticos da professora Ester 
Nunes Bibas será mediado pela análise discursiva sob a perspectiva bakhtiniana, A partir desse enfoque analisaremos o terceiro e o quinto livro, então, localizados dentre os livros da coletânea "Páginas Brasileiras". O terceiro livro é direcionado à terceira série do ensino primário, e apresenta textos voltados para a leitura e interpretação gramatical da língua portuguesa, dentre estes, apresenta textos que dão visibilidade ao papel da educação, da escola, do professor e dos alunos. Além de conteúdos de matemática, história do Brasil e textos sobre a paisagem da região amazônica, aspectos do estado do Pará e do povo paraense. O quinto livro, direcionado à $5^{\mathrm{a}}$ série do ensino primário, traz o subtítulo "seleta".

Figura 1 - Capa e Contracapa; Terceiro Livro / Quinto Livro.
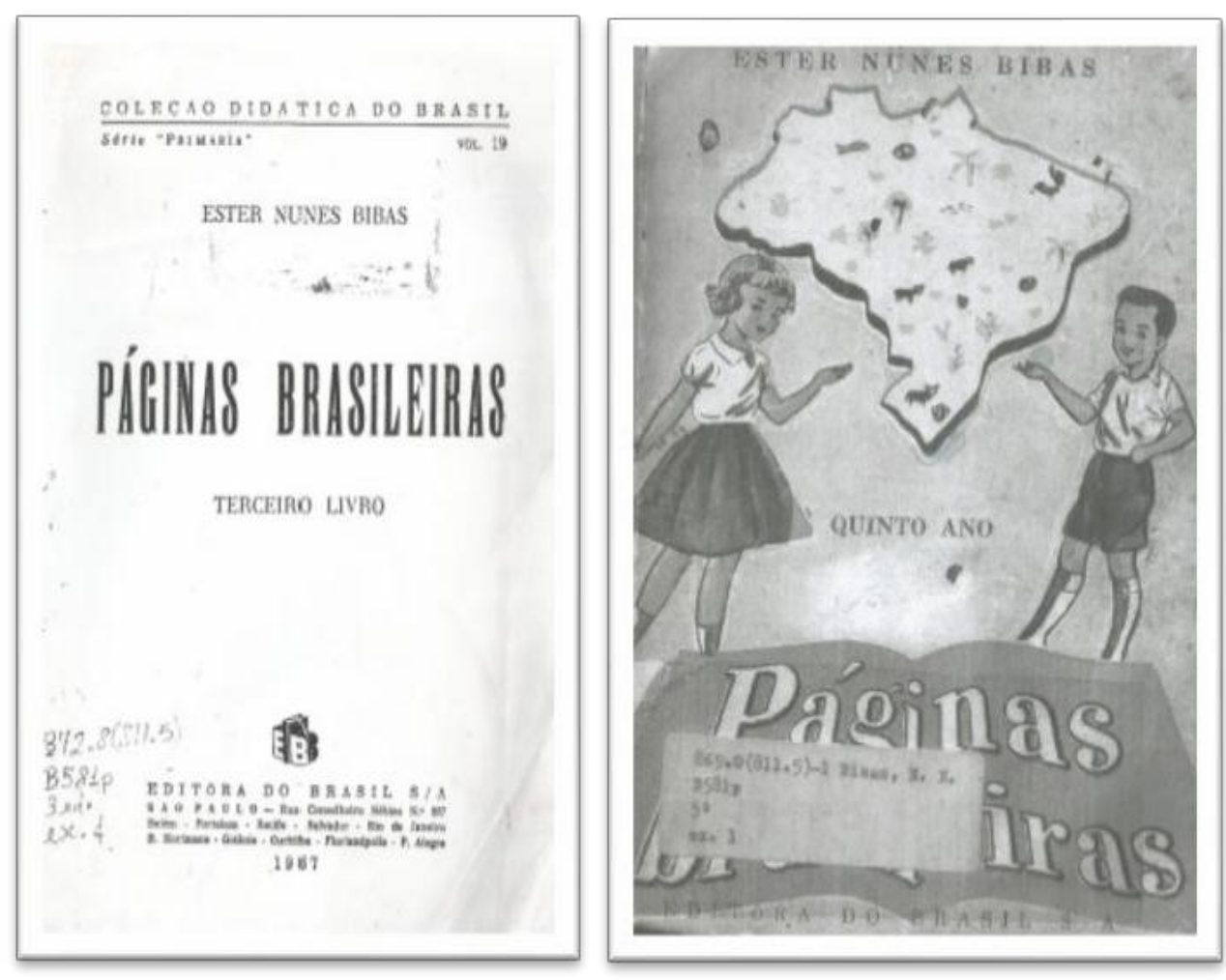

Fonte: Pesquisa de campo.

Este livro apresenta textos selecionados de autores brasileiros, paraenses e textos de escritoras paraenses sobre diferentes temas. Estre os autores nacionais, Rui Barbosa, Olavo Bilac, José de Alencar, José Veríssimo, Euclides da Cunha; entre os autores paraenses, Artur Porto, Cônego Ápio de Campos, Osvaldo Orico, Thomas Nunes, De Campos Ribeiro e entre as escritoras, os textos de Ermelinda de Almeida, Auta de Souza, Estela Maris, Hercilda Clark.

Utilizaremos também algumas poesias do livro "Rimas do Coração" desta autora que 
traduzem os caminhos percorridos como mulher, professora e escritora.

Como já mencionado, analisaremos os escritos de Ester Nunes Bibas a partir do campo do "gênero do discurso", ao focalizar os ditos, os escritos, e os silenciamentos presentes nos discursos textuais enunciados pela autora, que além de revelar muito sobre quem escreve, sua formação e seu pensamento educacional, desvelam também, as matizes morais, educacionais e ideológicas inerentes ao contexto paraense presentes no momento de circulação de ideias e discursos diretamente vinculados aos valores, a moralidade e a religiosidade como tons da cultura local. Nesse contexto, o livro didático se circunscreve como produto cultural por revelar e ser revelador da cultura local e regional. E no circuito escolar, o livro escolar tornase elemento mediador das práticas de linguagem e da comunicação, assim como,referência propedêutica de saberes escolares no âmbito do social, do político, do cultural, do científico e do ideológico, na medida em que o saber escolar se constrói na aproximação do saber científico, das referências culturais de uma dada sociedade. Dessa maneira, o livro didático se reveste como "artefato cultural" que veicula normas, condutas e maneiras de ser e viver, tornando-se instrumento normatizador da formação identitária de um povo, em especial da criança e do jovem paraense que adentravam neste momento nos grupos escolares de Belém e arredores.

A perspectiva discursiva bakhtiniana traz um novo olhar em relação ao campo da linguagem e dos eventos de comunicação. Este pensador da linguagem relaciona a língua e a linguagem como campos diretamente relacionados às condições concretas dos sujeitos enunciadores. Ou seja, os discursos enunciados são constituídos de forma transversal pelo meio social, político-ideológico que situam os diferentes sujeitos: o autor, o escritor e o (s) leitor (es) numa relação dialógica e dialética diante dos sentidos e significados construídos socialmente. 


\section{A TRAJETÓRIA DA PROFESSORA ESTER NUNES BIBAS}

Todo o processo de construção da trajetória de Ester Nunes Bibas, enquanto mulher, professora e escritora do campo da educação paraense, objetivou a produção de uma narrativa histórica pautada no gênero biográfico, com ênfase à apreensão intelectual dessa professora normalista. Uma narrativa histórica com vistas à valorização desta mulher paraense, sua trajetória pelos caminhos da educação e outros percursos transitados, que outorgaram o lugar de sujeito produtor de saberes, especialmente no campo didático-pedagógico; embora a autora e sua produção didática neste campo estejam sob uma condição de invisibilidade pela ausência da mulher professora e escritora nos registros oficiais da histórialocal.

O gênero biográfico a partir das últimas décadas do século passado vem ganhando centralidade nas pesquisas históricas, observando-se nesse campo o aumento da produção de estudos biográficos. O que demonstra não somente o retorno deste gênero historiográfico, mas também sua valorização como fonte de produção da escrita histórica para o reconhecimento do papel e da atuação dos indivíduos; o relato de pessoas que testemunham sobre os sujeitos estudados sob a condição de silenciamento. Concebendo-se a história de vida biográfica como escrita historiográfica.

A Nova História Cultural passou a explorar os estudos biográficos como instrumento de análise da prática cultural dos indivíduos pela apreensão de "vidas concretas vividas", demarcadas pelas apropriações culturais de um dado período histórico. Neste contexto histórico, a narrativa biográfica "trata do individual, da trajetória de uma dada vida, específica, concreta" (CARINO, 2000).

Neste contexto de escrita historiográfica, Le Goff (1999), nos chama atenção para o fato de que "escrever biografias não é uma tarefa simples", considerando as questões teóricometodológicas nesse processo de construção. Questões pontuadas por Carino (2000) com relação à produção biográfica.

\footnotetext{
Do ponto de vista epistemológico, como cuidar da generalização, ou seja, como descobrir a interseção entre a trajetória individual e a sociedade na qual essa trajetória é percorrida? Observando a questão de outro ponto de vista: como estabelecer o contorno do individual, isolando-o e, ao mesmo tempo inserindo-o no coletivo? (CARINO, 2000, p. 163).
}

Questões estas que passaram a ser dirimidas, na medida em que, o gênero biográfico passou a se subsidiar nas demais abordagens historiográficas, e em especial nos fundamentos das ciências humanas, possibilitando à escrita biográfica uma ênfase a uma narrativa de uma 
vida de forma coerente e significativa de uma pessoa, num dado período histórico. Para tal, sendo necessário situar os acontecimentos no contexto histórico em que ocorreram para compreensão do sujeito, sua trajetória, contextos e contradições, considerando que cada momento é único. Desta forma, sem a pretensão de esgotar todos os acontecimentos de uma dada vida. Segundo Roiz (2012), um estudo pautado numa análise dialéticaentre acontecimentos, conjunturas e estruturas, elites e massas, indivíduos e grupos em suas relações, de modo a considerar as contradições, as permanências e as mudanças observadas ao longo de uma trajetória de vida, que levaram ao romper com o contorno linear de um percurso, de posições e de atuações.

A produção de uma narrativa sobre a trajetória da professora Ester Nunes Bibas tencionou construir uma história de vida pautada no método biográfico, enquanto caminho ou método de pesquisa estratégico para a efetivação de uma práxis investigativa "interativa", com diferentes fontes que perpassaram por registros documentais, registros (auto)biográficos e, relatos de familiares, como fontes que localizaram a vida, a formação, a atuação profissional, e o pensamento educacional presente nos livros didáticos de sua autoria. Esta professora transitou pelos caminhos da educação paraense desde 1907, quando se tornou professora normalista e somente se afastou deste campo de atuação pela aposentadoria aos 70 anos de idade. $\mathrm{O}$ que demonstra uma presença marcante no cenário educacional paraense. Para Franco Ferrarotti (2001), o método biográfico se sustenta, como processo investigativo, ao localizar a trajetória de um sujeito singular não de forma isolada, mas diretamente associada ao contexto social, político, econômico, cultural e educacional, que localiza o transitar do sujeito biografado. E nesse processo investigativo, o processo interativo se apoia em aportes epistêmicos plurais para se compreender o sujeito, objeto da biografia em suas identificações plurais, como pessoa, como profissional, como escritor, como político entre outras atuações e inserções no cenário societário, em que sujeito se encontra localizado; o que permite a percepção do trâmite deste indivíduo entre o espaço privado e o espaço público. Este autor referenda esse trâmite do individual, do profissional, como esferas de atuação que interpenetram o público e o privado.

Aspectos, então considerados como "polo dialético" fundamental a ser observado nas produces biográficas:

Ao levar em conta a concepção de horizonte histórico, que significa em primeiro lugar, o caráter não intemporal, (e) não desarraigado das relações materiais extra subjetivas, dos documentos (auto)biográficos e em segundo lugar, o conjunto das relações estruturais, que são formalizados em instituições bem expressos nos comportamentos e costumes (FERRAROTTI, 2001, p. 11). 
A construção de uma escrita biográfica intelectual de Ester Nunes Bibas, enquanto mulher, professora e escritora no cenário educacional paraense, inicialmente traz a intensão de romper com a condição de silenciamento e de invisibilidade da trajetória profissional e do pensamento educacional desta escritora paraense na contemporaneidade. Ao mesmo tempo, que a presente produção biográfica, ao retirar a autora da penumbra promoveu a sua recolocação como sujeito histórico produtor e divulgador de saberes didático- pedagógicos para o ensino primário, a partir de um processo investigativo pautado na questão central norteadora para a compreensão do lugar ocupado por Ester Nunes Bibas no cenário educacional do estado do Pará

Ester Nunes Bibas se situa historicamente entre o grupo de professoras que se destacaram no campo da educação. Se localiza historicamente entre as mulheres que estabeleceram uma ponte entre o século XIX e o século XX. No entanto, sua trajetória e sua produção intelectual se encontram silenciadas e desconhecidas no momento atual. Nesse grupo formado por mulheres educadoras e escritoras não referenciadas pela história da educação e são rememoradas pelos rastros e pelas lembranças de familiares, de amigos e por seus escritos poéticos ou de outra natureza.

A ocultação desta professora e de sua produção didático-pedagógica se expressa pela escassa documentação a respeito da trajetória pessoal e profissional desta educadora paraense. Sendo localizados escritos pontuais que registram de forma fragmentária a vida e a obra desta professora. Dentre a coletânea de 05 livros didáticos de sua autoria, apenas o volume 03 e 05 , endereçados ao terceiro e ao quinto ano do ensino primário foram encontrados. Diante da ausência de registros nos arquivos e bibliotecas públicas, recorremos a relatos testemunhais de familiares, amigos e escritos (auto)biográficos da autora, que trouxeram pistas a respeito da trajetória e do engajamento de Ester Nunes Bibas em diferentes campos de atuação.

Todo o processo de construção biográfica desta escritora paraense nos possibilitou a compreensão dos aspectos marcantes da história de vida, diretamente relacionados a seus itinerários, sua formação, sua atuação profissional. Uma mulher que se constitui pelas relações de proximidade com sua família; junto aos sujeitos no processo de escolarização e no decorrer do fazer profissional. Ester Nunes Bibas se constituiu mulher letrada com reconhecimento no campo da poesia e campo da educação, enquanto professor normalista e escritora de livros.

Uma constituição de mulher que longo de sua vida vai sendo marcada pelos aspectos sociais, políticos, econômicos e culturais conformadores da sociedade belenense. Uma 
história de vida e uma trajetória feminina que se constrói num cenário societário notadamente pautado em valores arraigados no tradicionalismoque referendavam a autoridade e o poder do masculino.

No campo da história da educação ganharam evidências, as narrativas biográficas, que localizam professores e professoras em suas trajetórias, em suas experiências pedagógicas, que demarcaram com seus saberes o fazer pedagógico e os processos ensino-aprendizagem no seu tempo de atuação profissional. Um processo que tem trazido do passado e posto no centro da história da educação, a vida, as experiências, obras e pensamentos de professores e professoras até então, sob a condição de invisibilidade.

\subsection{ESTER NUNES BIBAS SOB O OLHAR (AUTO)BIOGRÁFICO}

A escrita de si é entendida por Margareth Rago (2013), como a "aventura de contarse" e "voz", que revela seu autor em "carne e osso" para o leitor. A escrita autobiográfica localiza as ações de quem escreve no âmbito familiar, profissional, social e sobre os fatos marcantes, muitas das vezes, rememorados de tempos distanciados, mas que referenciam a trajetória da vida do sujeito que fala ou escreve, e nesta narrativa sobre si, deixa-se "ler e ver" a constituição deste sujeito em suas redes de relações em seu tempo e espaços transitados.

Rago (2013), em sua análise sobre os escritos autobiográficos de mulheres brasileiras, chama a atenção para o tipo de escrita marcada pela tradição masculina na área literária, como campo que disseminou o retrato da mulher brasileira. Enquanto que a escrita feminina sobre si, vem em contraposição a essa construção feminina, considerando-se nesta escrita que as representações da mulher são expressas em um processo de construção, de "devir" e de uma subjetividadeinconclusa.

\subsubsection{Poema: " $E U$ "}

Venho de longe, de rios e igarapés de águas claras, estradas bonitas, luares estrelados duma cidade flor, cheirosa a jasmins e malva rosa.

Venho da terra formosa de serenatas, violões, açaí, madrugadas lindas e crepúsculos incomparáveis!

Sinto ainda, como um sonho feliz, a carícia do banho de água salgada, a alegria dos pássaros, em barcos à véla, o encanto das margens verdes, pelas quais, corre, assustado, o guará bonito de penas vermelhas,

$\mathrm{Na}$ saudade, volto a minha infância venturosa, ouço alegremente o sino da igreja, soando Ave Maria, quando eu, criança ainda, rezava à Virgem Mãe do Céu!

Venho de campinas floridas e gorjeios da passarada azul, da terra de meus pais, a minha cidade flor - Vigia!

Fui e sou ainda como árvore frondosa! Floresci, dei frutos e sombra. 
Meus ramos viçosos, multiplicaram-se em flores e ainda hoje há um sol que os afaga, nos sorrisos de meus netos e netas.

Cresci à sombra de carinhos e afetos, fortaleci-me na beleza dos campos, ao ar livre, pisando descalça, ervas macias, cheias de orvalho e depois, sorrindo a vida, recebi a mocidade em róseas taças de luares, estudei, casei, multipliquei-me e hoje vejo, sinto que vivo noutras vidas, glorificadas pelo meu grande amor de Mãe!

Meus ramos ainda ascendem ao azul e vão na luz das estrelas, o perfume e vigor que oferecem à haste a fortaleza necessária para vencer as intempéries!

Portanto, "ainda há solem" inverno de meus cabelos e foi a velhice que me deu inspiração para escrever os versos deste livro (Ester Nunes Bibas, 1958, p. 7).

Sob o olhar poético, Ester Nunes Bibas constrói um retrato sobre si e sobre sua trajetória, numa espécie de autobiografia, que revela a trajetória da autora, em uma "escrita sobre si", transcrita em uma poesia, que se encontra no livro "Rimas do Coração", publicado em 1958, período em que a autora tinha 70 anos de idade. Nesta obra literária, a autora, escreveu a poesia "EU", como texto introdutório. Aos 70 anos de idade, a autora descreve quem é Ester Nunes Bibas e seus caminhos percorridos a partir de um processo de rememoração e interpretação sobre a constituição de Ester Nunes Bibas, como menina, como mulher, como professora e seu potencial como escritora.

A escrita de si, enunciada por Ester Nunes Bibas, traz a sinalização, ainda que pontual, inconclusa, por seus ditos e silêncios sobre sua história de vida e sua intelectualidade. No poema rememora momentos marcantes pelo exercício da palavra escrita, a poesia, como forma de registro poético de uma história de vida e levada a público no momento em que escreveu seu livro "Rimas do Coração". No texto poético, a autora faz um reconhecimento per si, sobre uma mulher que "fala" e a torna pública mediante a publicação de um livro.

Na primeira e segunda estrofe desse poema, a autora retrata aspectos de sua infância vivida na cidade de Vigia/PA, cidade, de onde é originária. A autora faz emergir uma imagem desta cidade nos fins do século XIX, em que a autora convive com seus familiares. Pelo destaque nos versos, a autora traz as lembranças dos aspectos geográficos e ambientais desta cidade interiorana do estado do Pará, que a autora traduz pelo sentimento de saudade do seu tempo de menina e (re)significando nesse momento de escrita sobre si: como beleza dos rios, igarapés, estradas bonitas, de campinas floridas, de passarada e terra formosa e cheirosa a flor. Destacando, nesse território longínquo no tempo, as boas lembranças vividas em Vigia, no seu tempo de menina: o banho nas águas salgadas, a pés descalços pela relvas, os passeios de barco a vela, vivências lembradas como um "sonho feliz". Ou seja, a autora revela uma vida tranquila, pelo menos sem grandes preocupações, e ou necessidades neste contexto social e cultural que caracterizava a cidade de Vigia, interiorana, pesqueira, localizada aproximadamente à 200 quilômetros da cidade de Belém. Ester Nunes Bibas, embora tenha se 
transferido para cidade de Belém muito jovem, para dar continuidade aos estudos para além do ensino primário, manteve vivas lembranças de sua terra natal. Uma mulher atrelada aos vínculos sociais, culturais e as belezas geográficas ambientais da cidade de Vigia.

Em seguida, a autora menciona de forma bem rápida, a chegada de Ester na mocidade: "sorrindo a vida, recebi a mocidade em róseas taças de luares". O que demonstra que a autora se localiza entre a palavra e o silêncio sobre si nesta fase de sua vida. Ainda que fale de uma vida em sorriso e uma primeira impressão de uma mocidade feliz, alegre. Faz um registro sem detalhamentos, as lembranças se encontravam localizadas no campo da subjetividade. Algo transparece na vida da autora, a presença e o amor familiar como elemento de enlace e proteção no crescimento e constituição de Ester Nunes Bibas.

A religiosidade, neste poema, referendada pela fé católica, será uma marca referencial da mulher Ester Nunes Bibas ao longo de sua vida, em que declara sua devoção à Mãe do Céu.

Para Maria Lúcia Homem (2012), a literatura e ou a poesia, apresentam-se "estruturalmente" como uma escrita marcada por "presença e ausência". Entretanto, nas entrelinhas do silêncio dos escritos, no calar das palavras sou do seu sentido simbólico, o autor se deixa ver pelo não "poder dizer", que permite um redesenhar a representação do autor; seja traduzido pelo poder da censura, seja pela obediência às regras e princípios sociais, culturais e religiosos que instituem costumes e comportamentos sociais. No entanto, o implícito, o sujeito se revela de forma silenciosa ou transgressora.

Um aspecto relevante presente na estrofe de $\mathrm{n}^{\mathrm{o}}$ 05: "estudei, casei, multipliquei-me e hoje vejo, sinto que vivo noutras vidas, glorificadas pelo meu grande amor de Mãe!", a autora se localiza como mulher que estudou e que se tornou letrada, embora reconheça o casamento e seu papel de mãe com louvor, ao assinalar a importância da família que se multiplicou, alcançou em outras vidas (gerações) neste momento, pelo grande amor no exercício de ser mãe. A autora em seu escrito referenda a condição da mulher ao papel materno e ao exercício continuo de ser mãe, condição referendada na sociedade brasileira e paraense, enquanto papéis cristalizados de esposa e mãe. Embora, em meios aos afazeres do lar, a escritora vai se recolocar em outros fazeres, na docência e na literatura, assumindo a identidade de mulher da palavra e da escrita, posições presentes nas estrofes finais deste poema, em que a escritora reforça seu potencial criador e produtor da "escrita", quando afirma, ainda na "velhice", graças ao elevar seu "pensar" entre o azul das estrelas" encontrou o "perfume e o vigor" para continuar produzindo suas escrituras num tempo marcado pelas dificuldades daidade. 
Assim, o saber e o poder de "escrever" seus pensamentos, seus sentimentos e suas experiências, proporcionou a Ester Nunes Bibas a fortaleza para vencer as "intempéries" na sua caminhada, tornando-a uma mulher forte, que realizou projetos pelo domínio do escrever sobre seu chão, sua vida, sua família, sobre a educação; e transformou seus sonhos em versos poéticos.

Outro aspecto presente neste poema, a religiosidade referendada pela fé católica, como uma marca da identificadora da mulher Ester Nunes Bibas, mulher extremamente religiosa, que aflora desde a infância, associada a herança religiosa portuguesa presente no município de Vigia desde os tempos coloniais.

Nessa escrita de si e ou escrita autobiográfica, Ester Nunes Bibas, entre fatos e conquistas que fabricam sua trajetória, ainda que marcada por silêncios, e uma escrita que registra a incompletude de seu ser, se deixa ler e abre a percepção de um sujeito-mulher ao mesmo tempo "uno" e "plural", racional, intelectual, autora, escritora e mulher que se expressa na trajetória de uma vida. Assim, Ester Nunes Bibas chega a uma síntese sobre si: "Fui e sou ainda como árvore frondosa!, mulher forte e com pujança para a escrita. Floresci, deifrutosesombra numa reinterpretação do "EU" que assume uma configuração de um passado em direção a uma transição para a modernidade, garantida pelo domínio do falar e da escrita, e notadamente no romper com o "calar" em um contexto sociocultural belenense, marcado pelo tradicionalismo e o conservadorismo em relação a participação da mulher no espaço público e o não reconhecimento da intelectualidade e da autoria da escrita feminina.

\subsection{ESTER NUNES BIBAS: VIDA E OBRA}

A professora e escritora, Ester Porto Nunes é paraense, nasceu em 1888 no município de Vigia, localizada a 200 quilômetros da cidade de Belém, no nordeste do Estado do Pará, teve uma vida longa, falecendo aos 84 anos, em 1972, na cidade de Belém. É filha de Gratuliano da Silva Porto Nunes, que atuava como intendente de Vigia, uma espécie de prefeito nomeado e da professora Constantina da Costa Nunes, professora primária, chegando a ser diretora de escola. Seu pai ao assumer o cargo de intendente tornou-se uma figura política e social de destaque. Ester Nunes Bibas é sobrinha do professor, diretor de escola e literato Bertoldo Nunes e prima do Tomaz Nunes, intelectual, poeta e membro da Academia Paraense de Letras. Casa-se com David Jaime Bibas, jornalista do jornal A Província do Pará, responsável pela coluna de portos e viagens, era de origem judaica de Marrocos, da cidade de Tanger e incorpora o sobrenome do esposo, tornando-se então, Ester Nunes Bibas; com o 
casamento, tornou-se mãe de Gratuliano Bibas, Tereza Bibas, Sílio Newton Bibas, Heli Bibas, filhos, que tiveram também inserção no campo da escrita, da educação e da arte.

O contexto familiar dos "Nunes" em Vigia esteve diretamente associado ao magistério e ao campo literário e, nesse cenário, a presença marcante dos pais, o destaque alcançado pelo tio Bertoldo Nunes, como professor e literato e pelo primo, o poeta Tomaz Nunes, que para além da fronteira vigiense tornaram referências importantes no estado do Pará. Acreditamos que a partir dessas referencias familiares, Ester Porto Nunes desde a infância desenvolveu o gosto pela leitura, pela escrita e seu acesso ainda criança ao mundo das letras. Assim, o pertencimento a uma família importante e de condições materiais e intelectuais na cidade de Vigia e na cidade de Belém tornaram-se fatores positivos para que Ester Nunes se encaminhasse e viesse a se tornar importante intelectual no campo da literatura e da educação no decorrer de sua trajetória, como literata e no magistério primário.

Ester Nunes Bibas, como outras mulheres que nasceram no final do século XIX, iniciou seu letramento e seu estudo primário no espaço do lar, sendo alfabetizada pela própria mãe, que exercia o magistério em Vigia. Uma realidade educacional bem presente em outras cidades e outras regiões do país, em que a educação de meninas reforçava a sua condição feminina no âmbito do lar. Ao mesmo tempo em que, o letramento de meninas se constituía nesse momento histórico, privilégio de algumas meninas e moças, ao se considerar que o "direito" à educação era reservado a poucos, os pertencentes aos grupos econômicos majoritários. Neste cenário de desigualdade social, a educação de "moças abastardas" era realizada nas próprias casas, sob a orientação de pais e preceptores, sob uma condição de concessão (LOPES, 2011, p. 119). Nesse contexto de formação feminina, esta autora reforça em suas análises, que a condição familiar era elemento fundamental para a educação de meninas e moças, a saber:

Durante o século XIX, a educação recebida pelas mulheres era, portanto, privilégio de uma minoria rica. Como regra, as meninas pobres não recebiam qualquer espécie de educação formal, interessando aos pais mais o aprendizado das prendas domésticas do que da leitura e da escrita (LOPES, 2011, p.119,120, apud RIBEIRO, 1996).

Após seus estudos iniciais, Ester Nunes Bibas se transfere com a família para a cidade de Belém, muito jovem ainda, para dar continuidade a seus estudos. Ingressa na Escola Normal do Estado do Pará, considerada como instituição educacional para a formação de professores primários; formando-se como normalista aos 20 anos, no dia 27 de novembro de 1908, na gestão do governador Augusto Montenegro. Ester Nunes Bibas torna-se normalista 
num momento histórico significativo, correspondente aos primeiros anos da República Brasileira e com grande interferência do Estado na organização e na expansão da educação nacional e local.

Entre 1901 e 1909, o governo do estado do Pará, aliado ao processo de fortalecimento do Estado Republicano passou a disseminar os ideários e os projetos republicanos, entre os quais, a política nacional de expansão da educação pública com vistas a criação e ampliação dos grupos escolares, como novo modelo arquitetônico de escolas e novas práticas educativas, que proporcionassem a ampliação do acesso e permanência dos alunos na educação primária. No Pará, o empenho do governo em realizar melhorias nas condições estruturais das escolas e na valorização do trabalho dos professores oportunizou um processo de reordenação da escola e da educação como forma de reduzir a evasão escolar. Considerando-se que a escola nesse momento, se transforma em espaço de formação e preparação dos "cidadãos republicanos" para os tempos de progresso e civilidade (COSTA, 2015, p. 1).

Nesse contexto de expansão do ensino primário, Ester Nunes Bibas e outras normalistas tornam-se professoras habilitadas para a docência no ensino primário. Momento político marcado pelos ideários republicanos, pelo boom da borracha e pela expansão do ensino, que implicaram em grandes mudanças para o estado do Pará e para a região amazônica. Mudanças de toda ordem, e provocar nas capitais amazônicas a busca pela educação, com o propósito de civilizar o povo da região segundo os padrões civilizadores europeus. As capitais da região e o povo da região deveriam ser "civilizados" para o alcance da modernidade

Segundo registros de Meira (1988), Ester Nunes Bibas, como professora, lecionou no Colégio Progresso Paraense, considerado referência no ensino particular no Estado do Pará. Este colégio, sob a direção do professor Artur Porto, proporcionou durante anos o ensino de crianças e jovens das camadas médias e altas da sociedade belenense. Entretanto, a professora Ester Nunes Bibas somente alcançou notoriedade na educação, a partir do exercício do magistério público nas escolas da rede pública de ensino. A professora permaneceu na educação pública até aos 70 anos, quando foi aposentada pela compulsória. Esta professora chegou a exercer o cargo de orientadora pedagógica nos grupos escolares Barão de Rio Branco, Dr. Freitas e Rui Barbosa, nessa atividade, realizava o acompanhamento pedagógico das atividades de ensino das professoras e dos alunos do ensino primário, dados informados pela senhora Vânia Bibas Rio, neta de Ester Nunes Bibas (2016).

Uma longa jornada como professora primária, o que demonstra a dedicação desta professora à educação pública. 
Clóvis Meira (1988), em seus escritos, relata que Ester Nunes Bibas, foi agraciada com várias medalhas. Foi escolhida como Professora do Ano em 1959, essa homenagem foi prestada pela Sociedade Paraense de Educação, presidida pela professora Hilda Vieira. Nesta homenagem, a professora Graziela Moura Ribeiro faz um discurso em reconhecimento ao trabalho desta professora no campo da educação. Recebeu a medalha comemorativa ao Centenário da Escola Normal, assim como, medalha comemorativa ao Centenário de Morte de Paulino de Brito. Em 1960, recebeu o título de honra e mérito outorgado pela Câmara Municipal de Belém. Mesmo afastada do magistério, Ester Nunes Bibas, sempre esteve envolvidas em movimentos e realizando palestras relacionadas ao ensino. Neste campo, emprestou sua voz e seus escritos em prol da educação do Pará. Sendo autora da letra do hino do Grupo Escolar Pinto Marques. Clóvis Meira (1996), referenda:

\footnotetext{
Esther Nunes Bibas, figura extraordinária de mulher, que além de ensinar crianças, criar e educar os filhos, levava os seus conhecimentos bem mais longe, escrevendo pela imprensa diária, publicando livros, versejando, fazendo das cordas da lira o seu encantamento e dos que a conheciam (CLÓVIS MEIRA, 1996, p. 127).
}

Na obra A Lira na Minha Terra (1996), Clóvis Meira num trabalho incansável, trouxe a tona poetas paraenses desconhecidos, "perdidos no tempo" e, nesse resgate, a professora e poeta Ester Nunes Bibas. A maneira como descreve a vida e a pessoa de Ester, demonstra um apreço e um reconhecimento da importância desta autora paraense, que viveu num passado não muito distante, mas totalmente esquecida pelos registrosoficiais.

Segundo relato do professor Jaime Bibas (2015), neto da professora Ester Nunes Bibas, apesar de se encontrar em fase de recuperação, se mostrou solícito em nos receber, e nos trouxe pelo esforço da memória alguns indícios sobre importantes fatos ou fontes possíveis de se encontrar mais pistas, que possibilitassem conhecer melhor a trajetória desta educadora paraense. No início do seu relato, nos colocou o seu desejo de ter escrito sobre a memória histórica de seu pai e de sua avó, por considerar notável a atuação profissional de se pai como fotógrafo e sua avó no campo das letras e da educação. Afirmou-nos ter convivid com a avó quando criança e que havia uma relação de proximidade entre ele e a avó. No momento, ainda retém muitas lembranças, mas pelo tempo foram se tornando fragmentadas, pontuais e fora de uma linearidade temporal, considerando que Jaime Bibas participava das conversas coloquiais no seio da família.

Algumas situações ficaram em aberto, como a data de nomeação da professora Ester Nunes Bibas na Rede pública de ensino no estado Pará, que segundo relato de Jaime Bibas, teria ocorrido no primeiro governo de Magalhães Barata, em uma audiência pública, em que o 
intendente estadual conversava e atendia as petições de pessoas que participavam desses momentos, pedindo a intervenção do governo para a nomeação de cargos na educação, na saúde e em outros setores governamentais, além de petições de foro pessoal.

Segundo relatos do professor Jaime Bibas (2015, 2017), Ester Nunes Bibas, se dirigiu a uma das audiências realizadas pelo governador Magalhães Barata e nessa reunião relatou ao interventor estadual, a trajetória de sua mãe como professora do magistério primário na cidade de Vigia e expôs seu desejo de trabalhar na educação pública. Ester Nunes Bibas saiu dessa audiência com a carta de nomeação e apresentação para o magistério primário do Estado do Pará. Informações relatadas em momento de entrevista, embora, não tenha precisado a data e ano da nomeação de sua avó. E acrescentou ainda que sua avó, apartir de então se tornou apoiadora política de Magalhães Barata, se tornando "baratista" ferrenha.

Podemos observar uma lacuna histórica sobre a entrada de Ester Nunes Bibas no Sistema de Ensino do Estado do Pará, considerando-se sua formação de normalista em 1907 e pelos relatos de Jaime Bibas, sua entrada teria ocorrido somente na década de 1930. O que revela uma ausência de registros ou de memória histórica a respeito da atuação profissional desta educadora paraense. Há uma lacuna de no mínimo de 23 anos entre a formação pedagógica e sua efetivação nas escolas estaduais. Neste momento sem respostas para preencher essa lacuna deixada pela história da educação local. Todavia, podemos nos juntar aos questionamentos da professora Vânia Bibas Rio: A década de 1930 teria marcado o retorno da professora Ester à Educação, após crescimento dos filhos ou talvez após ter se tornado viúva? Diante da ausência/presença de Ester Nunes Bibas, nos aliamos ao contexto político educacional de seu tempo para perceber os discursos "autorizados" para a educação, e seus protocolos a serem observados e seguidos.

Ester Nunes Bibas é contemporânea das novas fórmulas educativas que vão orientar e reordenar tanto fazer pedagogico, quanto o processo de aprendizagem. Tais fórmulas são vistas como novas práticas educativas ou recursos didáticos a serem efetivados pela educação elementar ou primária, com a finalidade de formar os novos sujeitos para os novos tempos societários. Esta autora escreve uma coleção didática para o ensino primário, intitulada Páginas Brasileiras, publicada pela Editora do Brasil com várias edições entre a década de 1950 a 1960. Na verdade, uma coleção que reunia 05 livros destinados ao atendimento de professores e alunos da primeira à quinta série do ensino primário. São livros que subsidiaram a Educação Pública do Estado do Pará. Ester Nunes Bibas reúne nessa coleção, textos de sua autoria e de autores consagrados. Esses textos vinham acompanhados de vocabulários, exercícios e apresentavam capítulos destinados a História do Brasil, História do Pará, noções 
de higiene e conhecimentos científicos relacionados às funções orgânicas, anatomia e fisiologia. Esta autora, além desta coletânea escreveu o livro de poesias "Rimas do Coração". Segundo Meira (1988), a autora escreveu em jornais locais como a Província do Pará, Folha do Norte, Estado do Pará e em revistas da época. Ester Nunes Bibas, apesar de atuante e reconhecida no seu tempo de educadora e de escritora, pouco se sabe na atualidade a respeito de quem foi Ester Nunes Bibas, sua trajetória como professora e escritora. Seu trabalho intelectual ficou no passado e sem visibilidade no presente, havendo dificuldades de se localizar a coleção completa desta escritora. Uma condição que lhe outorga um lugar de invisibilidade e de exclusão no campo da intelectualidade e da produção escrita. Conseguimos acessar no momento, informações parciais, o que nos coloca numa fase de contínua investigação, havendo a necessidade de uma pesquisa mais apurada no escavar dos "escombros" e tirar da obscuridade os textos produzidos pela autora, como fonte historiográfica que desvele a fala, o dito e o não dito como sinalizadores de um tempo, de uma história da educação, de um povo e de uma mulher professora e escritora que alçou voo e emancipação intelectual.

\subsection{CAMINHOS TRANSITADOS POR ESTER NUNES BIBAS}

Ester Nunes Bibas apresenta uma história de vida demarcada por diferentes percursos, que se entrecruzam na constituição da mulher, da poetisa, da religiosa, da política, da professora e escritora de livros didáticos para o ensino primário. Uma trajetória histórica construída entre os percalços das limitações impostas pela sociedade local e pelas possibilidades do possível; Ester se constitui uma mulher "paradoxal", enquanto sujeito singular, "uno e plural" que se revela para além dos ideários conservadores e patriarcais dominantes sobre a representação da mulher paraense. Na medida em que, a identidade da mulher Ester Nunes Bibas vai sendo construída no processo de acesso ao contexto educacional e cultural desde o cenário sociocultural de sua cidade natal, que lhe proporcionou o letramento inicial e sua inserção ao mundo da literatura e dos saberes diversificados quando passa a participar da Sociedade Literária e Beneficente Cinco de Agosto na cidade da Vigia. Uma experiência vivenciada ainda muito jovem, mas que lhe atribuiu competência intelectual para alçar o lugar de mulher letrada no campo das letras e daeducação. 


\subsubsection{Pelos Caminhos do Privado: A vida Familiar}

Alguns aspectos da vida familiar são trazidos pelos relatos dos professores Vânia Bibas e Jaime Bibas (2015, 2016, 2017), netos que moram em Belém e que guardam algumas lembranças de sua avó. As lembranças estão relacionadas a conversas coloquiais no convívio com a avó, quando viúva passou a morar com seu filho mais velho Gratuliano Bibas, pai de Vânia e Jaime Bibas.

No âmbito da família, Jaime Bibas relata que sua avó sempre foi muito presente nas comemorações e acontecimentos familiares. No meio familiar, Ester Nunes Bibas era admirada por todos pela maneira de ser e pelo lugar reconhecido em que chegou. Jaime Bibas (2017) relata ainda que conheceu Ester Nunes Bibas na velhice e adoentada "bastante quebrada", em decorrência do fato de livros Páginas brasileiras, "produzidos" somente por sua avó, inicialmente de forma manuscrita e depois editados, não terem sido adotados oficialmente pela Secretaria de Educação. O não reconhecimento de sua obra teria provocado mágoas e adoecimentos. Entretanto, traz uma recordação muito clara de sua avó, como uma figura carinhosa e ao mesmo tempo autoritária. Com relação à educação dos netos, determinava o que deveria ser feito. Era uma "avó mais antiga, ao mesmo tempo presente e carinhosa, forte e ao mesmo tempo doce", de quem tem um grande apreço. Sentiu muita falta de sua avó e lamenta no momento de seu falecimento, por encontrar-se trabalhando no Rio Grande do Norte e não se fazer presente neste momento.

Os netos de Ester Nunes Bibas no momento das entrevistas assinalam por serem crianças no convívio com a avó, mas ainda guardam lembranças de alguns momentos desse convívio. Vânia Bibas Rio recorda de momentos com sua avó, quando esta vem morar com seu pai, o senhor Gratuliano Bibas e lembra ainda de suas saídas para ir trabalhar, "colocava seu casaco e ia acompanhar as escolas e os professores, em um trabalho que levava muito a sério". "Depois da família, a educação era seu bem maior”, diz Vania Bibas Rio. (2016)

Vania Bibas Rio (2016) recorda que sua avó, apesar da personalidade forte, era uma mulher alegre e que sempre participou de momentos festivos, ainda em sua cidade natal em que ainda muito jovem participava dos saraus em família, que adentravam pela madrugada, como retrata a poesia de Ester Nunes Bibas “Aquelas Madrugadas”. 
Figura 2 - Jornal "O Vigiense”- Outubro de 1964

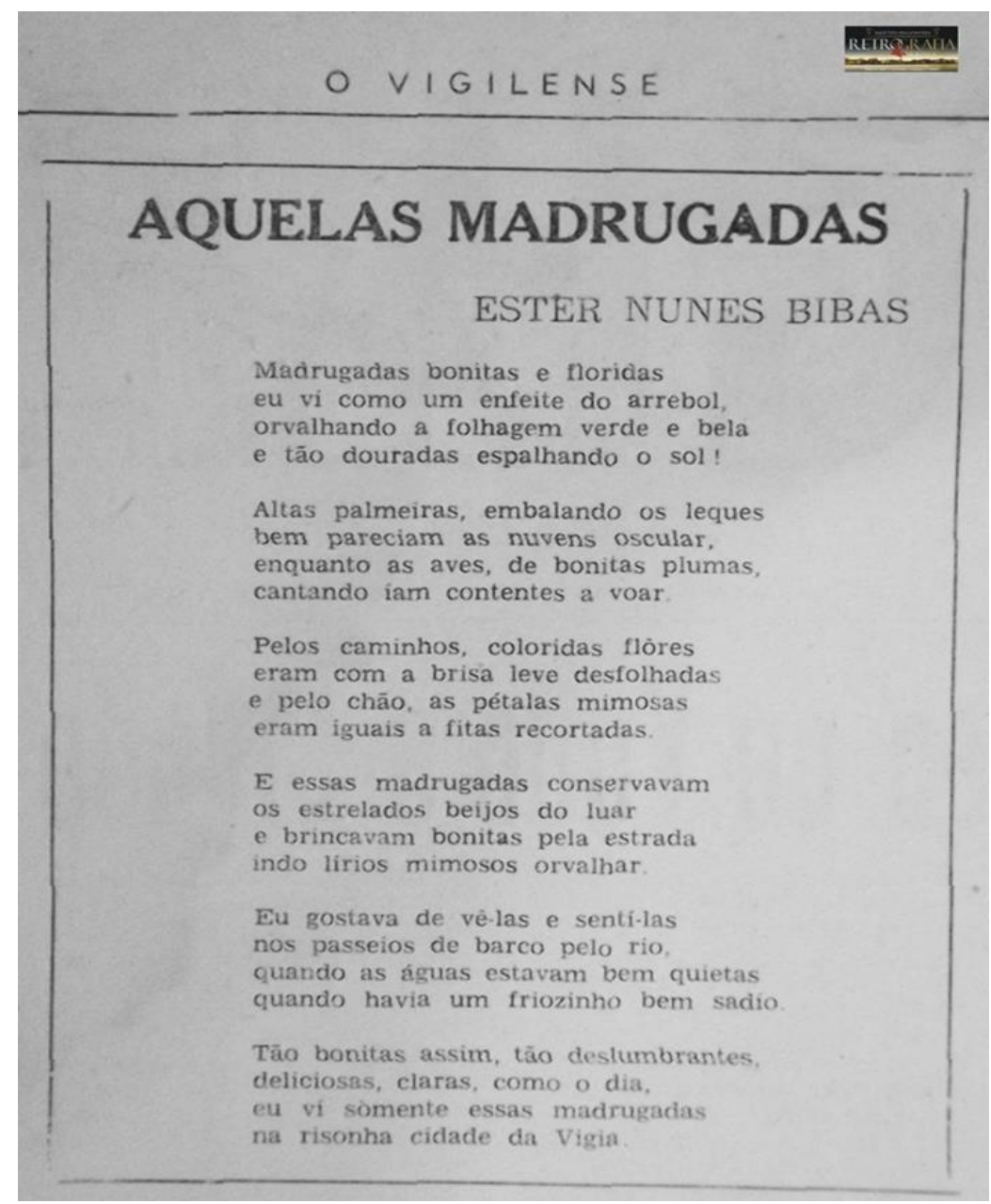

Fonte: Retrografia Vigilenga

O Poema Aquelas Madrugadas de autoria de Ester Nunes Bibas, trazem a tona, momentos vivenciados pela autora em sua cidade natal, uma escrita poética, que sinaliza a vida familiar festiva dos "Nunes" de Vigia. Como diz Vania Bibas, os saraus eram frequentes e que Ester Nunes, fazia-se presente, ainda muito jovem, uma vez que, são lembranças rememoradas neste poema remete à vida de Ester Nunes Bibas no município de Vigia-Pará.

Ester Nunes Bibas na convivência com o filho Gratuliano Bibas e seus netos, sempre participava dos momentos em que seu neto Jaime Bibas e amigos, se reuniam e tocavam ao som do violão as músicas solicitadas por Ester, o que demonstra o interesse pela música, como demonstrado no poema de sua autoria "Poetizando os Violões", dedicado aos jovens Claudio Veloso Moura e Jaime Oliveira Bibas. 
Figura 3 - Jornal a Folha do Norte

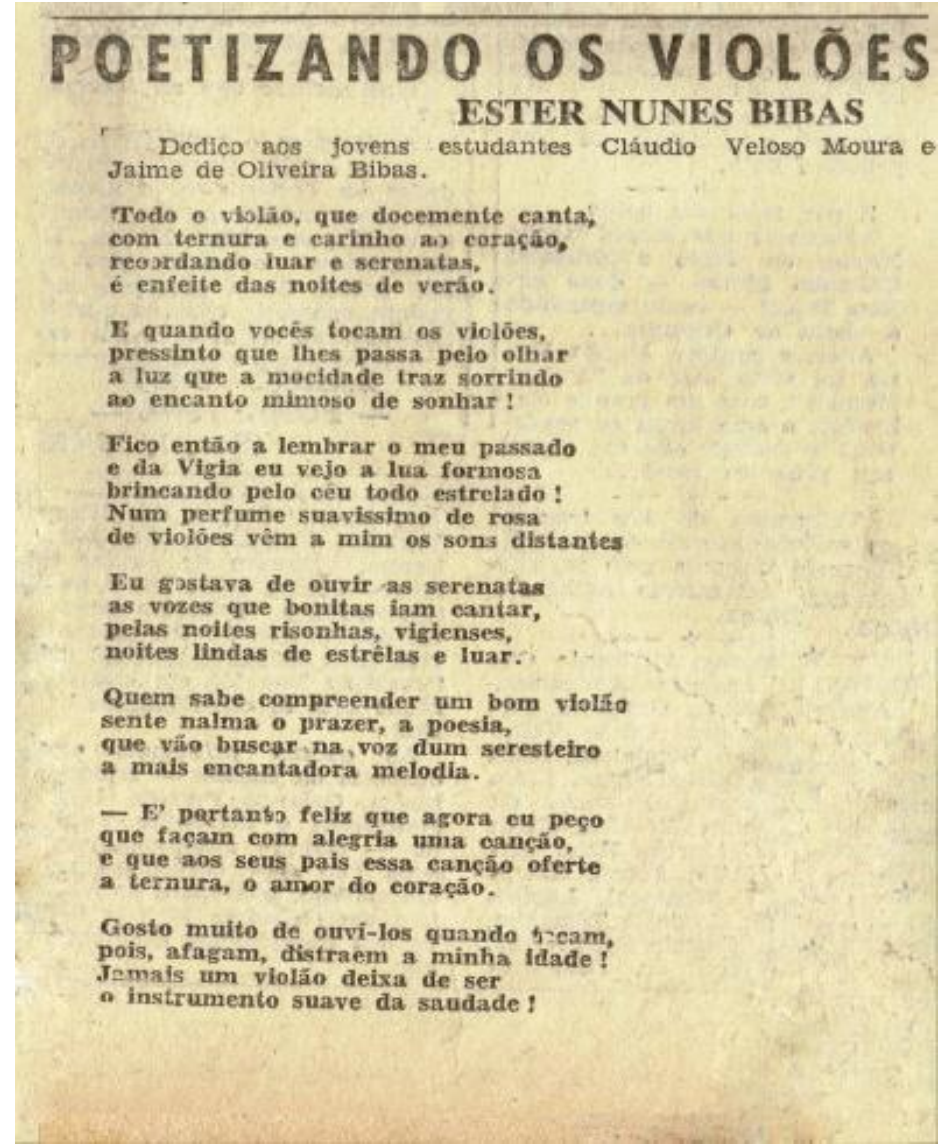

Fonte: Jornal A Folha do Norte, p. 9, 26/05/1963.

Em 1963, Ester Nunes Bibas, conta com 75 anos de idade, e ainda apresenta neste momento uma ativa participação no dia a dia com a família, principalmente com as atividades musicais em que seu neto participava em família, atividades que inseria a participação direta de Ester Nunes Bibas e revela o bom relacionamento que Ester mantinha com o neto Jaime Bibas e os amigos e amigas de seus netos. Como diz Jaime Bibas (2017), uma presença marcante nas atividades cotidianas e nos eventos familiares.

Jaime Bibas (2017) assinala que sua avó foi muito religiosa e essa religiosidade provém de suas origens, pois, o pai era muito religioso e a vida em vigia ocorria em torno da igreja Católica local e, ao longo de sua vida, manteve essa religiosidade, que influenciou a família Nunes Bibas.

\subsubsection{Pelos Caminhos Literários}

Os caminhos literários sempre estiveram entrecruzados pelos caminhos transitados por Ester Nunes Bibas, considerando-se que o exercício da leitura e da escrita poética aconteceu 
ainda nos tempos de criança, graças á interferência do dinamismo literário desde os anos oitocentistas no município da Vigia, cidade de origem desta escritora e como resultante da atuação e do destaque de homens de letras, poetas e escritores no cenário vigiense.

A existência de uma elite intelectual na cidade de Vigia se faz presente desde o século XIX, e esteve associada ao processo de colonização portuguesa desta cidade, considerada como a mais antiga no estado do Pará, fundada em 06/01/1616, data anterior à fundação da cidade de Belém; assim como, ao trabalho das Ordens religiosas neste território. De maneira expressiva, a atuação da Companhia de Jesus, pela contribuição na formação religiosa, cultural e educacional prestada aos habitantes nativos, os habitantes da aldeia de Uruitá, os índios Tupinambás e seus descendentes.

Os jesuítas criaram estratégias formativas, ainda que, num contexto rudimentar de educação, possibilitaram nesta comunidade ribeirinha a constituição de leitores. Assim, uma ação educativa importante para o desenvolvimento cultural e político desta comunidade. Vigia se tornou vila em 25 de agosto de 1697 e eleva-se a condição de município, nos meados do século XVIII, em 1734, com destaque na Costa Oriental do estado do Pará.

A grande contribuição deixada pelos jesuítas se refere ao desenvolvimento da educação escolar, pautada em valores de civilidade às populações indígenas, vistas então, sob a condição de "selvageria". Neste sentido, a ordem jesuítica desenvolveu um trabalho evangelizador e colonizador, "capaz de uniformizar o ensino para além da catequização. Os religiosos construíram suas ações na educação de forma geral, buscando uma unificação no que diz respeito, principalmente, ao ensino religioso e a um nivelamento do ensino das primeiras letras" (ARAUJO, 2011, p. 33).

Um legado deixado pelos jesuítas e de outras irmandades em Belém em aldeias, vilas e cidades pela criação de colégios rudimentares para o ensino escolar e religioso. Segundo Clóvis Meira e José Ildone (1990), os religiosos tiveram a preocupação de reunir, ensinar o alfabeto, as primeiras letras, a escrita, num trabalho que foi se ampliando com a criação de seminários, colégios e bibliotecas com acervos para leitura, destinados para os alunos e para a comunidade em geral. Um empreendimento, ainda que, de forma rudimentar no início, mas que com o passar dos anos se transformou em importante legado para o desenvolvimento cultural de Belém e da cidade de Vigia. Observando-se, nesse processo formador, o disseminar de uma cultura letrada, a partir do acesso a livros de diferentes saberes, que se aliavam as certezas religiosas trazidas pelo catolicismo na Amazônia. Uma atuação que, de forma mais localizada, fez surgir na Vigia, uma elite letrada, no decorrer dos séculos XVIII e XIX. 
O cenário cultural, literário e intelectual vai demarcar a história da cidade de Vigia no decorrer dos anos oitocentistas e que se intensifica pelo clima trazido pelos ideários republicanos e da Belle Époque, vivenciados pela cidade de Belém e Manaus. Momento de mudança de hábitos, costumes e o empenho em busca de uma educação e de formação cultural como vetores para o alcance da modernidade e dacivilidade.

Neste cenário de grandes mudanças, os intelectuais e escritores ganham visibilidade pela divulgação e circulação de suas ideias, escritos e livros, tornam-se participantes de clubes, sociedades literárias e pontos de encontros de escritores que passam a discutir, a trocar ideias e a se posicionarem diante do contexto de "efervescência" da vida social e cultural na região. Vigia "foi impulsionada a um desenvolvimento pautado em bases urbanísticas, sociais e culturais, requerendo para si o mesmo clima de euforia, de civilidade e de modernização presentes nas grandes cidades" (ARAUJO, 2011).

No contexto vigiense surge a Sociedade Literária e Beneficente Cinco de Agosto em 01 de Outubro de 1871, sendo instalada em 05 de julho 1872. Seus fundadores eram políticos, escritores, jornalistas, professores, oradores, e nesse empreendimento, tencionavam proporcionar um ponto de encontro da elite intelectualizada e nesse desejo, trazer para a cidade de Vigia os "ares de intelectualidade"; pois, a finalidade primeira dessa associação se voltava para a publicação de obras literárias, textos referentes à política, à região ou de cunho científico. Entretanto esta sociedade literária promoveu ações educativas, culturais e de ajuda beneficiente à comunidade local.

Inicialmente, esta sociedade associava apenas homens letrados e de renome junto a comunidade local, que publicaram suas produções literárias, textos referentes a política, a religião ou no âmbito cientifico.

\footnotetext{
Entre os nomes que figuram na liderança o movimento para a fundação da sociedade, destacam-se os de Francisco Ferreira de Vilhena Alves, Márcio Ribeiro, Lauriano Gil de Sousa, Manoel Felipe da Costa, Francisco de Moura Palha. Gerôncio Alves de Melo, Abrahão Athayde, Quintino de Araújo Nunes e Seu irmão Bertoldo Nunes (tios de Ester Nunes), os padres Mâncio Caetano Ribeiro, Argentino Maria de Oliveira Pantoja, Manoel Evaristo Ferreira e [...] outros, apagados pela história e pelo tempo (ARAÚJO, 2011, p. 39).
}

A Sociedade Literária e Beneficente Cinco de Agosto objetivava distribuir a educação, o esclarecimento e benefícios ao povo, aos associados e seus dependentes, como, por exemplo, a destinação de recursos, em casos de enfermidade, e financiamento de despesas fúnebres, em decorrência de falecimento; apoiar a cultura e motivar o amor aos valores locais. Outra atividade essencial era promover, em parceria com a paróquia, o Círio de Nazaré, 
colaborando para a expansão da fé católica. A parte educacional seria exercida através da implantação de uma Escola Primária e de um Externato (estabelecimento de ensino onde só há alunos externos, ou seja, que não são residentes), para levar instrução gratuita à população local.

A Sociedade "Cinco de Agosto", criada há 144 anos, promoveu visibilidade e atribuiu autoridade e status institucional aos intelectuais vigienses:

\begin{abstract}
Àqueles que pertenciam a ela. reunidos em torno dela, esses homens desejavam introduzir e ampliar seus padrões culturais, buscando até mesmo elaborar para si uma identidade enquanto grupo que compartilhava os mesmos prazeres intelectuais, integrando-os em torno de uma instituição. Em outras palavras, as Sociedades Literárias, entre as quais a "Cinco de Agosto", acabaram criando uma forma de sociabilidade e expressão para uma elite heterogênea, que tinha em Paris seu maior espelho (SOEIRO, 2011, não paginado).
\end{abstract}

O trecho, transcrito pelo atual presidente da então, Associação Cinco de Agosto, Igor Soeiro (2011) na passagem dos 140 anos de fundação da Sociedade Literária e Beneficente "Cinco de Agosto" revela a participação e o reconhecimento de homens letrados da cidade de Vigia, enquanto uma elite intelectual ilustrada pelos valores e saberes civilizatórios parisienses.

Ester Nunes Bibas, a partir do ambiente cultural e literário da cidade de Vigia e a participação de familiares na liderança da Sociedade Literária e Beneficente Cinco de Agosto, desde a infância manteve proximidades com o mundo letrado e do exercício da escrita e em 1902, se torna sócia desta Sociedade Literária vigiense. Acontecimento registrado no livro de sócios desta sociedade. Informação localizada por Paula Maíra Cordeiro, em pesquisa realizada em 2016.

\footnotetext{
Aos 14 anos ainda se é muito nova para conviver em espaços restritos aos intelectuais da época. As mulheres (nesse momento) também não possuíam muito espaço nesses locais, compostos em sua maioria, por homens, em virtude da sociedade patriarcal, fortemente presente ainda no século XX (CORDEIRO, 2016, p. 12).
}

O que demonstra um reconhecimento a respeito da precoce intelectualidade de Ester Nunes no mundo da escrita literária. Ainda que, contando com o apoio e a influência familiar, Ester se insere no mundo das letras, como campo inicial para registrar seus pensamentos, sentimentos expressos em suas escrituras, publicadas na sociedade Literária Cinco de Agosto e em jornais locais, como O Vigiense, Folha do Norte, Estado do Pará, A província do Pará. E publica a obra literária "Rimas do Coração" em1958. 
Os escritos literários de Ester Nunes Bibas revelam o "lugar social" de onde a autora fala, e se deixa perceber como mulher, sua localização em relação ao pertencimento social, em relação à classe, etnia, escolaridade e a questão de gênero, enquanto mecanismos demarcadores culturais que demarcavam as representações de ser mulher. Nos quais, a escritora transita em suas bordas e fronteiras.

\subsubsection{Pelos Meandros da Política: Da defesa de direitos femininos ao apoiopartidário}

Vislumbrar a trajetória de mulheres paraenses na seara política, campo predominantemente masculino, impõe entraves na percepção da atuação feminina. Considerando-se o campo politico marcado pela presença masculina, pelas relações de poder e domínio que asseguram ao gênero masculino visibilidade. Nessa area de atuação, a exclusão das práticas femininas que assim como nas demais áreas públicas, não são reconhecidas ou referendadas. Assim, ao longo do processo histórico, o ambiente sociocultural paraense ocultou o trânsito da mulher pelo espaço público e a reafirmação de que a relação mulher e política são excludentes, pela contínua representação do lugar social do homem vinculado ao espaço público e o lugar social da mulher ao espaço privado do lar, como lócus específico da atuação feminina.

Luzia Álvares (1990), em sua pesquisa acadêmica referente à atuação política de mulheres no cenário paraense, de forma mais focalizada na cidade de Belém no período entre 1910-1937, identificou que, as mulheres paraenses desde as primeiras décadas do século XX transitam pelo espaço social, cultural, artístico e cinematográfico, em decorrência do dinamismo urbano local relacionado ao "boom" da borracha, aos ideários da Belle Époque e dos ideais norteadores do Estado republicano.

Neste período histórico, a nível nacional são identificadas mulheres "descoladas" da representação tradicional de ser mulher e que passam a transitar entre o espaço doméstico e o espaço público. Mulheres, ainda que vistas pela sociedade pelo foco das representações "marginais" do gênero feminino, se localizam em diferentes espaços sociais: doméstico, profissional, social, político.

No estado do Pará, no decorrer da Primeira República, a representação feminina perpassa pela condição "submissa", "passiva" e, do "Lar". No entanto, grupos de mulheres localizadas no segmento médio, oriundas de famílias "abastadas", iniciam sua inserção nos espaços "políticos/partidários". Mulheres que se tornaram sujeitos-objetos de estudo na Dissertação da Professora Luzia Álvares (1990). Mulheres que passaram a integrar as "Ligas 
e Legiões" femininas, que atuaram como "forças auxiliares" das agremiações partidárias, e das lideranças políticas. Daí, neste cenário, uma atuação invisível do feminino, embora considerada importante, pois, as mulheres atuavam no contato direto com os eleitores e na prestação de serviços assistenciais, como suporte ao atendimento dos interesses das lideranças políticas, a quem se vinculavam. Entre 1912 a 1921, a localização desse grupo de mulheres nas Ligas Femininas Lauro Sodré e ou Antônio Lemos e, posterior a esse momento, a participação feminina de forma indireta seja pelo apoio à familiares e amigos envoltos no movimento de 1930 e, com a vitória deste movimento, a inserção de muitas mulheres na Legião Magalhães Barata.

Segundo Álvares (1990), as mudanças políticas verificadas no país e no estado do Pará, interferiram nos "retratos de mulher" pela emergência de mulheres atuantes no cenário político, embora num ativismo político distanciado do processo de emancipação do feminino, relacionado à luta por direitos da mulher presentes em outros estados brasileiros que seguiam as bandeiras de lutas da Federação Brasileira pelo Progresso Feminino organizado desde 1922 sob a liderança de Berta Lutz. Entretanto no Pará, um grupo de mulheres, começou aganhar visibilidade no cenário político local. Entre estas mulheres, a advogada e jornalista Orminda Bastos.

\footnotetext{
Um acontecimento que ecoa na cidade de Belém e no estado do Pará, através do apoio da advogada e jornalista paraense Orminda Bastos: A sociedade paraense presenciou o debate sufragista desde a década de 1920. Em 1923, Orminda Ribeiro Bastos, advogada e jornalista, posicionam-se através da imprensa, desenvolvendo os pontos positivos e negativos que ela considerava essenciais nas reivindicações do movimento emancipacionista instalado no sul do país, através da Federação Brasileira pelo Progresso Feminino. Faz conferência para a Liga Cooperativa das Operárias de Fábricas, enfatizando a necessidade de instrução como ponto fundamental para a ascensão da mulher na luta pelos seus direitos políticos (ÁLVARES, 2011, GEPEM, UFPA).
}

No "Movimento de 1930", as mulheres paraenses participaram de forma indireta, apoiando, se solidarizando a familiares e amigos envoltos naquele movimento. Embora sendo notório que toda aquela movimentação estivera associada ao avanço liberal burguês, que possibilitara, naquele momento, os discursos de reformas políticas, entre elas, o direito do votofeminino.

Em 12/06/1931, um grupo de mulheres paraenses, Corina Pegado, Cloris Silva, Elmira Lima, Feliz Benoliel de Cavaco, Joanita Machado e Marieta Campos são as representantes das mulheres paraenses no $2^{\circ}$ Congresso Feminista do Brasil. E, a partir da participação de mulheres paraenses neste evento, ocorreram em Belém várias reuniões com vistas a 
organização do movimento sufragista e em 21/06/1931, é instalado em Belém, o Núcleo Paraense pelo Progresso Feminino diretamente vinculado a organização nacional coordenada por Berta Lutz.

Álvares (2011), em suas análises sobre a participação feminina nos meandros da política local, reconhece como fatores facilitadores desse engajamento político, a condição social, a interferência política e intelectual das mulheres que assumiram a direção desta associação feminista em Belém. Assim, identificam-se entre as sufragistas, mulheres da classe média, mulheres letradas e com reconhecimento social.

\begin{abstract}
Do registro dos nomes das sufragistas paraenses à frente da associação feminista, identificam-se mulheres com expressão no meio das letradas: Elmira Ribeiro Lima, jornalista, militante e conferencista espírita, (tia de Orminda Ribeiro Bastos); Feliz Benoliel de Cavaco, espírita, descendente de judeus, professora de piano (casara-se com o jornalista gaúcho Carlos Cavaco, contrariando a orientação familiar e étnica); Corina Pegado, filha do sindicalista Luiz Martins e Silva (solicitante, em 1929, do seu alistamento eleitoral, indeferido pelo Juiz Federal paraense). Desse grupo, podese identificar, ainda, Cloris Silva, espírita (ligada à Confederação Espírita "Caminheiros do Bem" dirigida por Elmira Lima), professora primária, exercendo atividades no Instituto Vieira (das professoras Joventina e Hilda Vieira); Helena Souza, professora de piano, do Instituto Carlos Gomes, jornalista, líder católica. O nível de classe destas mulheres é da camada social média, letradas, com livre acesso na imprensa e facilidade de oratória (ÁLVARES, 2011, GEPEM-UFPA).
\end{abstract}

Na organização inicial do Núcleo Paraense pelo Progresso Paraense é criada uma diretoria provisória, formada pelas seguintes participantes:

O Núcleo Paraense pelo Progresso Feminino é instalado oficialmente em 21 de junho de 1931, constituindo-se uma diretoria provisória sendo indicada Presidente de Honra a esposa de Justo Chermont, Izabel Justo Chermont. Os demais cargos são ocupados respectivamente pelas organizadoras do movimento: Presidente: Elmira Lima; Vice: Ana Leopoldina Borges Pereira; $1^{\mathrm{a}}$ Secretária: Cloris Silva; 2 Secretária: Antonina Prado; $3^{a}$ Secretária: Feliz Benoliel de Cavaco; Diretoras: Olímpia Martins, Helena Souza, Marieta Campos, Juanita Machado, Pétala Pfaender, Ester Nunes Bibas, Maria da Costa Paraense, Dolores Nunes; Tesoureira: Olga Paes de Andrade; colaboradoras: Hermínia Flávia de Miranda, Maria de Jesus Marques Alves, Carmem Rodrigues de Souza, Edith Barriga Cavalcante, Clara Martins, Zuleika de Carvalho Nobre, Ana Fonseca e Antonia Rodrigues de Souza (ÁLVARES, 2011, GEPEM-UFPA).

Na primeira organização do Núcleo Paraense pelo Progresso Feminino, encontramos Ester Nunes Bibas, como participante deste núcleo feminista. Uma posição que outorga o lugar de mulher engajada politicamente na defesa dos direitos da mulher, neste momento, num processo de efetiva participação de mulheres paraenses, que se destacaram na luta pelo direito do voto feminino. Ester Nunes Bibas tornou-se uma das ativas participantes, fazendose presentes nas passeatas realizadas em Belém, cujo, o objetivo era tornar público o 
manifesto de mulheres em defesa do voto e da participação política, como afirma Jaime Bibas (2017), baseado em lembranças sobreevento,

O Movimento sufragista defendido por esse segmento de mulheres provocou junto a comunidade belenense posições e contraposições ao direito do voto e a participação feminina na vida política. Movimento que ganhou destaque na imprensa local, que passou acompanhar e divulgar as reuniões deste grupo e todos os encaminhamentos do Núcleo Paraense relacionados à valorização da mulher paraense.

Neste direcionamento, Elmira Lima, presidente deste Núcleo publica o artigo: "Mulher, A Caminho!" no jornal Folha do Norte e neste referido texto é traduzido o papel social da mulher em meios às diferenças e desigualdades presentes na sociedade:

\footnotetext{
Patenteiam-se as diferenças existentes entre homens e mulheres desde a educação realizada no lar paterno, possível fulcro das desigualdades observadas entre os dois sexos. Na perspectiva da presidente do Núcleo é a mulher-mãe, a responsável, pelas rupturas com os desvios de educação, pois, se corrige o modo "autoritário" da filha não há motivo para conservar o "império" do "rei pequeno". Elmira acusa o sexismo que determina comportamentos "agressivos" aos homens e atitudes "delicadas" às mulheres, modos, aliás, vistos como "naturais" na formação dos dois gêneros. O movimento de implantação do Núcleo Feminista é o momento para instigar a mulher a rever sua postura masculinizada de criar diferenças na educação dos seus filhos responsabilizando-a, também, pelas desigualdades sofridas pelo gênero feminino (ÁLVARES, apud, 2011).
}

A organização feminista neste momento sob a pauta política da defesa do voto feminino, conta com a participação de mulheres com reconhecimento social, ou seja, são identificadas pelo lugar social em que transitam. Assim, são destacadas pela profissão que exercem, como advogadas, jornalistas, professoras, artistas, poetisas e instituições a que pertencem e como pano de fundo, a origem familiar. Entre 1931-1932, período em que o caminhar deste movimento é acompanhado pela imprensa local, a poetisa e professora, Ester Nunes Bibas, se insere entre as mulheres “intelectuais" pela presença na imprensa local, como poetisa e como professora no cenário da educação paraense. Percebemos que Ester Nunes Bibas apresenta uma atuação interligada como poetisa, professora e como política. Uma atuação semelhante a esse grupo de mulheres do Núcleo Paraense Pelo Progresso Paraense, mas não comum a outros segmentos de mulheres da sociedade paraense, ainda incrustadas na redoma do lar. O que transparece que Ester Nunes Bibas e as demais participantes desse movimento político, alçaram voo pela formação, pelo poder da escrita e da fala, e assim puderam problematizar e propor saídas para as mulheres via a educação, formação política para alcance aos direitos se a condição de cidadania, como direito de homens e mulheres.

O espaço político transitado por Ester Nunes Bibas e seu grupo do Núcleo Paraense 
pelo Progresso Feminino, traça além de um perfil de mulher engajada com os acontecimentos de sua época, aponta um direcionamento político seguido por este grupo, que provocou adesões e contraposições de pessoas e grupos que não viam com bons olhos o empenho e o reconhecimento da atuação feminina no espaço público. Considerando-se que tanto Ester e muitas de suas companheiras de movimento, são casadas, são mães e exercem uma profissão. Assim, a luta pelo voto feminino e sua legitimação, possibilitou a esse grupo de mulheres uma inserção no mundo político e nos espaços de poder oportunizado pelo movimento feminista. O transitar dessas mulheres pioneiras ganhou visibilidade pelo fato desta organização de luta e defesa de direitos da mulher paraense estar vinculado ao movimento nacional liderado por Berta Lutz.

Um movimento que mantém seu destaque até 1936, quando a direção política muda com a instalação do Estado Novo do Governo Vargas, e o movimento sufragista das mulheres sai de cena, momento em que as mulheres passaram a ser arregimentadas como eleitorado feminino pelos partidos e líderes políticos tanto a nível nacional e estadual. O novo cenário político brasileiro e paraense tornou necessário a "conquista" da nova mulher que neste período, se fez sujeito político eleitora e elegível num contexto, em que o Estado Novo impetrou novas formas de legitimação e domínio e o sujeito mulher nesse circuito político, passou a incorporar um novo papel ditado pela nova Constituição Nacional.

No estado do Pará se implanta o governo do Intendente Joaquim de Magalhães Cardoso Barata, e neste governo, mulheres são arregimentadas e tornam-se integrantes da Legião Magalhães Barata.

Segundo o relato do professor Jaime Bibas (2015, 2017), a nomeação desta professora para a Rede Pública de Ensino Primário, se deu em uma audiência pública em que o governador atendia a solicitação do povo paraense. Ester Nunes Bibas ao sair deste encontro com Magalhães Barata com a carta de efetivação para a docência no Ensino Primário público e a partir de então, Ester Nunes Bibas, torna-se "Baratista", ou seja, se torna apoiadora política do governo local e defende a bandeira política dos novos "ideários nacionalistas" presentes no governo Vargas e no governo de Magalhães Barata, ideários bem demarcado em nos escritos desta autora.

Um cenário político instaurado no país, que reforçou o papel tradicional da mulher e da professora, a quem é delegada a formação do sentimento pátrio da família e da nação brasileira. 


\subsubsection{Pelos Caminhos da Educação: Normalista, Professora e Escritora de Livros didáticos}

Ester Nunes Bibas, como outras mulheres que transitaram do século XIX para o século XX e, inseridas num cenário social tradicional, notadamente marcado pelas relações patriarcais, encontraram na profissão do magistério as possibilidades de mudanças em direção a uma maior autonomia e liberdade para concretizarem seus projetos de vida. A professora Ester Nunes Bibas encontrou no magistério primário um lugar ou um "entre-lugar" em que se dedicou a educação do estado do Pará por 50 anos de sua vida. Tornando-se nesse espaço, uma professora dedicada, amorosa e competente na função de docente. A educação se tornou uma das bandeiras de luta desbravada ao longo de sua jornada, pela qual, se empenhou pela melhoria do ensino primário ao se tornar escritora de livros didáticos para o curso primário.

\footnotetext{
Para as professoras primárias da primeira metade do século $\mathrm{XX}$, o magistério foi o ponto de partida, foi o possível no momento histórico em que viveram. Significou o trânsito do invisível para a visibilidade e a realização de algo que não fosse o único e prestigiado serviço doméstico, como reduto privilegiado da feminilidade. $\mathrm{O}$ magistério era o trabalho intelectual e assalariado sem conotação pejorativa; [...] conferia mobilidade social, maior liberdade e respeito entre as classes trabalhadoras, e possibilitava bem estar econômico (ALMEIDA, 2004, p. 6).
}

Ester Nunes Bibas se torna aluna na Escola Normal do estado do Pará nos primeiros anos do século XX e torna-se professora normalista em 1907. Momento histórico de estruturação do Estado Republicano brasileiro e período áureo da produção da borracha no estado do Pará e região amazônica. Contexto político e econômico nacional e regional, que transformou o lugar a educação como campo estratégico para divulgação e legitimação da ideologia positivista e do próprio Estado Republicano. Nesse contexto, a educação assume um papel importante para a formação do povo brasileiro e paraense diante das exigências de uma nova formação educativa com vistas à alteração de condutas, atitudes, mentalidades e a incorporação de uma qualificação do cidadão republicano, segundo os valores civilizatórios, como padrões de acesso ao progresso e a vida moderna.

Tais exigências impactaram o cenário educacional e possibilitaram o acesso massivo de mulheres às escolas normais. Entre as décadas de 1920-1930 o Censo Demográfico Brasileiro registrou no magistério primário a presença de mulheres em torno de 72,2\%; assim como, em outros setores do mercado do trabalho. Observando-se neste período, a participação da mulher no movimento pelo voto feminino e o direito ao acesso ao mercado formal de trabalho. 
A Educação tornou-se campo do "possível" e referendado para a atuação do feminino. Este cenário de inserção da mulher no mercado de trabalho fez com que muitas jovens de áreas interioranas buscassem as cidades para ingressarem nas escolas normais e tornarem-se professoras primárias, como mostra a trajetória da professora Ester Nunes Bibas quese desloca do município da Vigia para a capital para estudar na Escola Normal de Belém e tornar-se professora primária. A criação da Escola Normal do estado do Pará veio ao encontro das aspirações da população paraense, que não dispunha de boas escolas e nem de bons professores. A Escola Normal sendo referenciada como local de formação de verdadeiros professores. Embora, o professor Altair Souza (1972) registre em seus escritos, que “os primeiros anos de funcionamento da Escola Normal não corresponderam plenamente ao fim para o qual fora criada, em consequência de várias reformas, em geral infrutíferas" (SOUZA, 1972, p. 12,13).

A primeira Escola Normal do Pará foi criada em 1871 e extinguida em 15 de outubro de 1872 por não apresentar uma estrutura adequada ao ensino normal. A segunda Escola Normal foi mais bem organizada, instituiu propriamente dito o Curso Normal. Renasce pela portaria de 09 de junho de 1874, sob a direção do Dr. Pedro Carneiro de Freitas, diretor do Liceu Paraense. O funcionamento da Escola Normal foi se dando no espaço do liceu Paraense para os alunos e no Colégio Nossa Senhora do Amparo para moças. Somente em 1890, a Escola Normal passou a ter prédiopróprio.

Elizeu Clementino de Souza, em sua Tese de Doutoramento (2004), traz a observação, de que a aluna normalista se tornava apta ao magistério no decorrer de sua formação, período em que vai aprendendo a "Ser Professora" a partir do conhecimento que a professoranda vai tendo de si e das vivências no âmbito das escolas normais, através das quais, vai ganhando autonomia pessoal e profissional. Um aprendizado que se inicia pelos cuidados diários com uniforme, com os materiais e trabalhos escolares. Como "atitudes preparatórias" importantes para se tornar um(a) disseminador(a) de saberes e condutas a serem privilegiadas pela educação efetivada pela escola pública, alcançada assim, pelo empenho e pela organização e disciplinamento, o modelo de formação educacional a ser transmitida às camadas populares.

Nos primeiros anos do Estado republicano, a Escola Normal do Pará, "passou por uma reorganização que incluiram reformas na parte física e alteração no programa de ensino", no sentido de promover:

Um ensino inspirado em uma filosofia científica, onde a matemática, a astronomia, a física, a química deveria ser aprendida pela observação e experimentação, base de toda pedagogia, precisava de locais apropriados para acontecer. A construção do gabinete de física e química e de alguns reparos no prédio onde funcionava a escola, abrangendo a biblioteca e o gabinete de história natural, custaram 11: $489 \$ 792$ aos 
cofres do Estado em 1892 (COELHO, 2008, p. 129).

O que se observa em relação à trajetória da Escola Normal Paraense é um processo contínuo por melhoras estruturais, em virtude do número ampliado de candidatos em busca de matrícula no Curso Normal que extrapolava a capacidade da Escola, vista no cenário local como lugar de aprendizagem e qualificação de "professores normalistas", considerando que a Escola Normal sob a égide republicana, tornara-se um verdadeiro "Viveiro de Mestres".

A formação de professores e professoras normalistas a partir de 1890 era ministrada em 04 anos de estudos. As informações sobre esse processo de formação de professores normalistas descritas no trabalho de Tese do professor Raimundo William Tavares Junior (2008): No primeiro ano de formação, eram ministradas as disciplinas: Língua nacional, língua francesa, aritmética, geografia, coreografia do Brasil, coreografia do Pará, história universal, história do Brasil, história do Pará, introdução moral e cívica, caligrafia, ginástica, exercícios calestênicos para as mulheres e militares para os homens; desenho, geometria e costura para as mulheres. No segundo ano de formação, acrescentava-se literatura integrada a língua nacional, álgebra associada ao ensino da aritmética, cosmologia ao ensino de geografia, prendas domésticas ás alunas e pedagogia geral, metodologia, higiene e higiene escolar. No terceiro ano, Geometria plana, elementos de sociologia, direito pátrio, economia domestica como parte da disciplina moral e cívica, música vocal, instrumentos industriais, pedagogia. No $4^{\circ}$ ano, o estudo, a ministração de disciplinas práticas e instrumentais, o estudo curricular, o método de ensino frobel ${ }^{8}$ e prendas de agulhas para as jovens alunas. O estágio voltado para o trabalho docente se dava desde o primeiro ano nas escolas anexas.

As mudanças vão se alterando, conforme as proposições das reformas implantadas no campo da educação. Entretanto, é marcante nesse processo de formação generalista do professor normalista, em detrimento das disciplinas pedagógicas, assim como, a formação diferenciada, a partir de conteúdos de disciplinas específicas para os alunos e as alunas da escola normal, instituindo-se e mantendo-se uma formação desigual. A disciplina língua francesa se justifica pela aproximação dos ideários de civilização e civilidade a ser alcançado, em que a cultura francesa se tornou referência.

A elite paraense em tempos de belle époque incorpora a língua francesa como o idioma privilegiado nos meios sociais, assim como, o comportamento, o vestir, o falar de

\footnotetext{
${ }^{8}$ Friedrich Froebel (1782-1852), o criador dos jardins-de-infância defendia um ensino sem obrigações, porque o aprendizado depende dos interesses de cada um e se faz por meio da prática. Um dos primeiros educadores a considerar o início da infância como uma fase de importância decisiva na formação das pessoas.
} 
homens e mulheres estava associado aos novos padrões europeus. Neste contexto de afrancesamento localizamos Ester Nunes Bibas, que desde os cursos frequentados na Sociedade Literária Beneficente em Vigia, até seu ingresso na escola normal, estudou e aprimorou conhecimentos da língua francesa, passando a dar aulas particulares, por exímia competência no falar e no escrever daquela língua (BIBAS, 2015).

Ester Nunes Bibas como professora galgou o lugar de "uma das mais respeitáveis expressões do magistério primário”. Em homenagem feita pelo professor Clóvis Meira, à antiga mestra, no momento das comemorações dos cem anos de nascimento em discurso impresso pelo jornal O Liberal, em 05 de junho de 1988, afirma:

Hoje, dia 5 de junho, viva fosse, completaria 100 anos de nascimento a notável educadora que foi Esther Nunes Bibas, figura extraordinária de mulher, que além de ensinar crianças, criar e educar os filhos, levava os seus conhecimentos bem mais longe, escrevendo pela imprensa diária, publicando livros, versejando, fazendo das "cordas da lira" o seu encantamento e dos que a conheciam (MEIRA, 1988, O LIBERAL $^{9}$ ).

O Professor Clóvis Meira, como amigo próximo á família Nunes, esclarece a trajetória plural desta educadora, ao enfatizar o seu desempenho na educação de crianças. Que além do magistério primário, a jornada na criação e educação dos filhos e o prazer em versejar e escrever. Clóvis Meira constrói uma imagem de Ester Nunes Bibas como professora: como a imagem da paciência, dedicação e bondade "no acompanhamento dia após dia, ano após ano de crianças "broncas", iluminando e norteando o espírito de cada uma, é tarefa meritória, tão grande ou maior que o sacerdócio".

Pelo tempo de formação e atuação no magistério primário e segundo a apreensão de Meira (1988), a professora Ester Nunes Bibas apresenta um perfil de professora dedicada ao ensino e à aprendizagem de seus alunos, uma atuação que no dia a dia da profissão possibilitou a esta professora uma experiência e o desenvolvimento de uma capacidade de aprender diante das dificuldades do ensino. Vivências, que por certo, serviram como base para seus escritos na coletânea didático-pedagógica Páginas Brasileiras. Considerando que Ester Nunes Bibas inicia suas atividades como professoras aos vinte anos e afastando-se do campo educacional aos 70 anos de idade, pela aposentadoriacompulsória.

O movimento pela Escola Nova no país passou a questionar e a requer do campo educacional uma nova reorganização do ensino nacional e a defesa de uma melhor

\footnotetext{
${ }^{9}$ Jornal de maior circulação no Estado do Pará, pertencente à família Rômulo Maiorana.
} 
qualificação para os professores, através de estudos, participação de eventos educacionais que possibilitasse uma renovação no fazer pedagógico, mediante novos saberes que viessem renovar a formação intelectual dos professores. A professora Marta Chagas Carvalho (1998) observou em suas pesquisas, que os governos estaduais diante do movimento dos educadores em prol da Escola Nova, passaram a reorganizar seus sistemas públicos de ensino, na medida em que passou a incentivar professores, inspetores, diretores de escola, a participarem de momentos pedagógicos, de formação e participação como "iniciativas de impacto como inquéritos, conferências, cursos de férias, congressos (extensivos) a pais e mestres (como) apelo modernizador das reformas". Uma participação que levassem além dos questionamentos e novas aprendizagens para os educadores, que estes se tornassem produtores de "saberes pedagógicos".

Em Belém, vamos encontrar homens de letras, professores e professoras primárias, registrando suas produções intelectuais, a partir da experiência da sala de aula, e passaram a publicar seus artigos e ou palestras proferidas, como forma de divulgar junto ao professorado paraense, as novas proposições pedagógicas para a educação nacional. No periódico A Escola-Revista do professorado do Pará, vamos encontrar um grande número de trabalhos produzidos por professores e professoras normalistas, entre estes, destacamos a publicação de artigos de professoras primárias entre 1934 e 1935 nesta revista, a participação de professoras contemporânea da professora Ester Nunes Bibas. Entre estas, encontramos a professora Hilda Vieira, que publicou o artigo "Escola renovada e a criança", a Professora Antonieta Serra Freire Pontes, publicou o artigo "Os processos da Escola Ativa"; a professora Corina Lassance Cunha, o artigo, "A Escola Nova e sua Finalidade"; a professora Palmira Lins de Carvalho, o artigo: "Os processos da escola ativa no Pará"; a professora Graziela Moura de Paula Ribeiro, artigo: “O Professora do Leigo, particular ou público, deve repelir ou alimentar o ensino religioso nas escolas?”. Uma presença significativa de professores primários nem todos citados nesse registro, mas que publicizaram seus escritos e contribuições para o ensino no estado doPará

Embora, não tenha sido localizado nenhum escrito de Ester Nunes Bibas nesta revista paraense na década de 1930, encontramos escritos que registram seu reconhecimento como "intelectual de mérito e brilhante poetiza", segundo menção do Jornal vigiense, Cinco de Agosto em 1939. O que indica que Ester Nunes Bibas assim como as professoras Hilda Vieira, Antonieta Serra Freire Pontes, Palmira Lins de Carvalho e Graziela Moura de Paula Ribeiro, é uma das mulheres professoras que se tornaram intelectuais do campo da educação no estado do Pará e pertencentes a essa geração de mulheres letradas. O professor Clóvis 
Meira em homenagem à professor Ester Nunes Bibas, registra a escrita desta professora em vários jornais de Belém, embora, a pesquisa acadêmica não tenha localizado as indicações a respeito da escrita impressa deste professor.

Vânia Bibas (2016) menciona que sua avó "produziu muito", e era frequente presentear amigos com poesias e diversos textos, inclusive discursos para políticos ou senhores em cargos importantes. Entretanto, escritos que eram repassados sem a autoria dos textos produzidos. O que consideramos como um dos fatores que justificam a ausência de registros e a invisibilidade desta escritora.

Ester Nunes Bibas no campo da educação se tornou sujeito produtor de orientações pedagógicas referentes às práticas educativas, escritas e descritas em livros de sua autoria, "Páginas Brasileiras" A publicação desta coletânea permitiu perceber o fio condutor que traduz sua escrita, os ditos em suas entre linhas, a respeito de si, do seu pensamento, da sua formação pedagógica, de sua afirmação como sujeito histórico, social, ético cultural, que aprendeu a "cultivar" a cultura regional e paraense, como referência de saberes e de identidade de ser mulher e de um povo com características culturais muitopróprias.

Nos livros "Páginas Brasileiras", observamos que os textos de Ester Nunes Bibas sinalizam a presença marcante da cultura regional. Jaime Bibas (2015) relata que o desejo de sua avó em escrever livros didáticos para as escolas do Pará está relacionado a não aceitação pela escritora dos livros adotados nas escolas locais, por serem oriundos de outras regiões e dessa forma impor uma realidade e uma cultura que não era a do estado do Pará. Sobre esse regionalismo, Vânia Bibas (2016) comenta que, as paisagens, os escritos, as histórias, o folclore paraense é bem presente nos primeiros livros, em especial nos livros do $1^{\circ}$ e $2^{\circ}$ ano do ensino primário, em que a autora utiliza imagens de frutas, de animais, as florestas, os rios da região. Livros que consideramos importantes por demarcarem a escrita desta escritora paraense, no entanto esses respectivos livros citados ainda não localizados.

Trazer a tona o pensamento educacional de Ester Nunes Bibas, mulher, professora e escritora de livros didáticos para o centro dos estudos acadêmicos, no âmbito da educação paraense, sob a condição de sujeito-objeto, vem oportunizando, ao longo deste processo investigativo, o descortinar do processo de ocultação e silêncio em que se encontra esta educadora. Sua produção pedagógica, embora tenha sido circulado por décadas nas escolas paraenses. Encontra-se imersa num contexto de raros registros, ou de "não ditos" sobre su trajetória e sobre a obra, condição que outorgaram a essa professora e escritora um lugar de invisibilidade histórica.

O livro didático começou a ser produzido no Brasil a partir dos meados do século 
XIX. Sua organização estava sob as determinações dos programas oficiais vinculados à Política Nacional de Educação e se constituía em instrumento oficial da educação escolar e orientador das práticas pedagógicas dos professores.

Inicialmente os autores de livros didáticos eram homens de letras e ciências, mas com estreita ligação com setores institucionais diretamente ligados à efetivação da Política Educacional. Neste momento, a produção dos livros didáticos estava atrelada às estruturas de poder e seus discursos enunciavam a consolidação do "poder instituído".

Nos fins do século XIX, surge uma nova geração de escritores de livros didáticos; os professores-escritores. Assim, os educadores passaram a produzir livros de leituras, e outros escritos didáticos que subsidiavam as tarefas pedagógicas de professores e alunos. "Os autores dessa geração possuíam na maioria das vezes experiências pedagógicas provenientes dos cursos primários, secundários ou das escolas normais" (BITTENCOURT, 2004, p. 483).

Neste momento histórico, a produção para este campo se voltavam produção de livros de leituras, ou de "lições de coisas" que incorporavam diferentes saberes.

Os estudos acadêmicos sobre os livros didáticos surgem no Brasil na década de 1970 e tornou-se crescente nas décadas seguintes. Em 1990, a tese da professora Circe Bittencourt, tornou-se referencial para os estudos sobre o livro didático no Brasil, por trazer uma abordagem inovadora sobre o livro didático, concebido como instrumental da cultura escolar, subsidio para as práticas pedagógicas e desvelador das concepções educacionais vigentes. Os estudos nessa área de pesquisa vão se tornando crescente no país, pois:

\footnotetext{
A realização de seminários, a criação de centro de estudos, núcleos, projetos de pesquisas e cursos de Pós-Graduação relacionados ao o livro didático, contribuíram para a produção de 800 trabalhos resultantes de pesquisas sobre o livro didático no Brasil entre os anos 2001 a 2011 nas áreas de educação, letras, história, matemática (MUNAKATA, 2012).
}

Neste cenário de ampliação de estudos, o livro didático ganhou visibilidade como produto cultural, instrumento didático-pedagógico, constituinte do saber e da cultura escolar e como fonte para a visibilidade dos processos educacionais, por revelar práticas, discursos pedagógicos sobre o ensino-aprendizagem.

O livro didático como uma produção escrita, revela o texto escrito, seu autor, seu pensamento, seu saber, sua organização, suas apropriações epistêmicas, que demarcam discursos a respeito do conhecimento escolar, das práticas pedagógicas e dos conteúdos programáticos. Assumindo desta maneira o caráter prototípico de modos de pensar e ensinar e aprender. O livro didático se reveste do caráter propedêutico "porque enuncia-porque age - 
intervém em palavras, pode-se dizer - na cena predicativa da prática didática". (PORTELA, 2015, p. 8).

Os professores-escritores se situam na acepção do termo intelectual, enquanto criadores e ou agentes que participam da construção do saber como "mediadores culturais, que contribuem para difundir e vulgarizar os conhecimentos" (Idem, 2015, p. 261).

Ao escrever um livro, o seu autor está incorporando o papel de um produtor cultural e notadamente se reconhece nele o "o papel de comunicação" de ideias, pensamentos, valores normativos à vida social, na medida em que este artefato cultural se destina a um público leitor, que se apropria desta comunicação, faz a sua releitura de seus ditos e escritos, tornando-se também produtor. Nesse contexto, a leitura e a escrita como prática criadora; possibilitam o recriar e ou reelaborar uma escrita primeira.

O ato de escrever assume grande importância, não somente por registrar ideias, pensamento e trazer orientações e experiências para o campo do saber a que se destina, mas por possibilitar públicos leitores, que além de partilhar suas ideias, orientações e dos bens culturais, esses novos públicos tornam-se sistematizadores desse saber, sob outras óticas de saberes e vivências. Assim, tornam-se ao mesmo tempo, receptores-produtores de bens culturais e nessa relação de produção que se cruzam numa via de mão dupla, pois, "tudo que o homem diz ou escreve, tudo o que fabrica, (é) tudo o que deve informar-nos sobre ele" (LE GOFF, 1990, p. 89).

O texto escrito na verdade é resultante de práticas sociais, de vivências, experiências e acúmulos de aprendizagens, constituindo-se uma cultura material, ao mesmo tempo em que, se reveste como bem simbólico, seja pelos processos de construção, seja pelos usos e pelas percepção dos significados e dos sentidos atribuídos as práticas sociais determinantes nesse processo de produção cultural. Além de revelar quem é o autor ou produtor, a escrita, a fala e o pensar, que oportunizam aos leitores, novas percepções, novos usos e novas apreensões da vida em sociedade, pelas imagens e representações que dizem a respeito de si, dos outros e do mundo em que vivem e partilham e essa apreensão vai sendo construída nesse processo contínuo de circulação de um produto cultural.

Por suas contribuições Chartier (2002), torna-se referência para a compreensão do nosso sujeito-objeto Ester Nunes Bibas, inseridos no contexto de instituições de ensino, a história do livro, as sociabilidades, produções material voltada para as escolas,, das práticas da leitura e da escrita, como cenários que estão associados ao contexto educacional. E nesse contexto sociocultural perceber a pedagogia proposta para professores e alunos amazônicos, em especial com relação ao pensar e o fazer pedagógico desses outros sujeitos, aos quais, 
estas proposições são endereçadas. Observando-se que o pensamento educacional e as práticas pedagógicas estão matizados pelos processos de formação, relações políticas e, pelo contextocultural.

No Terceiro livro de Páginas Brasileiras (1967), localizamos uma carta intitula "Uma Redação Verdadeira" escrita por Vânia Bibas, que retrata o momento em que a coletânea dos livros "Páginas Brasileiras", é lançado em Braile. E numa conversa coloquial com sua prima, informa detalhes deste momento de reconhecimento da importância da obra produzida por sua avó, a professora Ester Nunes Bibas:

\footnotetext{
Uma Redação Verdadeira

Belém, 27 de junho de 1963. Querida prima Heliana,

Ontem nossa vovó autografou os livros "Páginas Brasileiras", de sua autoria, para a Escola "Álvares de Azevedo", destinada ao ensino dos cegos e amblíopes, aqui em Belém. Foram momentos emocionantes para todos os membros de nossa família, foi pena que você e todos os nossos residentes na Guanabara, não estivessem presentes! $\mathrm{O}$ pequeno livro que você conhece, transformou-se num volume de quase cinquenta centímetros de comprimento, pois assim são todos os livros transcritos em Braile e próprios para a leitura dos cegos. Os desenhos das bandeiras brasileira e paraense estão lindos, assim como todos os demais. Foi uma grande emoção para a vovó, ouvir a Cristina, uma criança que não enxerga e que já está na $3^{\mathrm{a}}$ série primária, ler para os presentes, uma das lições do livro, que em tão boa hora, escreveu.

Sabe qual a lição que a Cristina leu? Aquela que se intitula "O Sol". Como leu direitinho, com auxílio de seus minúsculos dedos!

Heliana, atualmente, não há mais dificuldade para os cegos, como você sabe, eles podem estudar pelo processo Braile e ser grandes homens cursando, se quiserem até Universidades!

Quando Vovó escreveu "Páginas Brasileiras" nunca pensou que seus livrinhos se tornassem tão úteis!

Querida prima, certamente você transmitirá estas noticias aos bondosos tios e, digalhes que os livros foram impressos na Fundação do Livro do Cego, em São Paulo. Espero que você esteja tão alegre como eu, pela vitória de vovó e por ela estar contribuindo, um pouco, para o ensino dos cegos, no Brasil.

Receba, com os demais priminhos e queridos tios, um grande e jubiloso abraço da Vânia (BIBAS, 1967, p. 59-60).
}

Esta carta inicialmente como registro familiar ganhou um alcance maior no momento em que é impressa como texto de leitura. Ao mesmo tempo se tornou um registro de um momento importante do reconhecimento da escritora de Ester Nunes Bibas e de seus escritos didático-pedagógicos. Neste momento em que passa a subsidiar o ensino-aprendizagem dos alunos da Escola Álvaro Azevedo. A presente carta torna-se o registro mais detalhado sobre a contribuição de Ester Nunes Bibas para o ensino especial pelo fato da não localização de nenhum exemplar em Braile.

Este texto presente no Terceiro Livro de Páginas Brasileiras, é reafirmado pelo registro da imprensa local, no momento em que é traduzida a Coletânea Paginas Brasileira para o braile. 
Figura 4 - Jornal Folha do Norte

\section{RONDA IITERÁRIA GEOFRAN}

Significativa vitória vem de conquistar o dr. Dionisio .Joăo Hare, ane teve seu livro sôbre "História do Pará" traduzida para - Braile passando a ser adotada na Escola nara cegos.

A professôra Ester Nunes Bioas tambóm teve seu livro "Páginas Brasileiras" traduzida para 0 mesmo alfabeto.

Fonte: Jornal Folha do Norte p. 3, 26/06/1963.

O registro a seguir, embora jornalístico, se constitui em um documento de guarda familiar, que registra esse momento de reconhecimento de obras didáticas paraenses, e neste recorte não foi preservado a identificação da fonte jornalística e data de publicação, entretanto, por se constituir um registro escrito e imagético que consideramos importante para sinalizar a trajetória da professor e escritora, sujeito-objeto desta tese, mantivemos no corpo textual neste capítulo, pois no conjunto de informações, então registradas, enunciam o reconhecimento da obra e do lugar de Ester Nunes Bibas no cenário politico-educacional do estado do Pará, quando do lançamento da coletânea Páginas Brasileiras em Braile. 
Figura 5 - Arquivo de Família

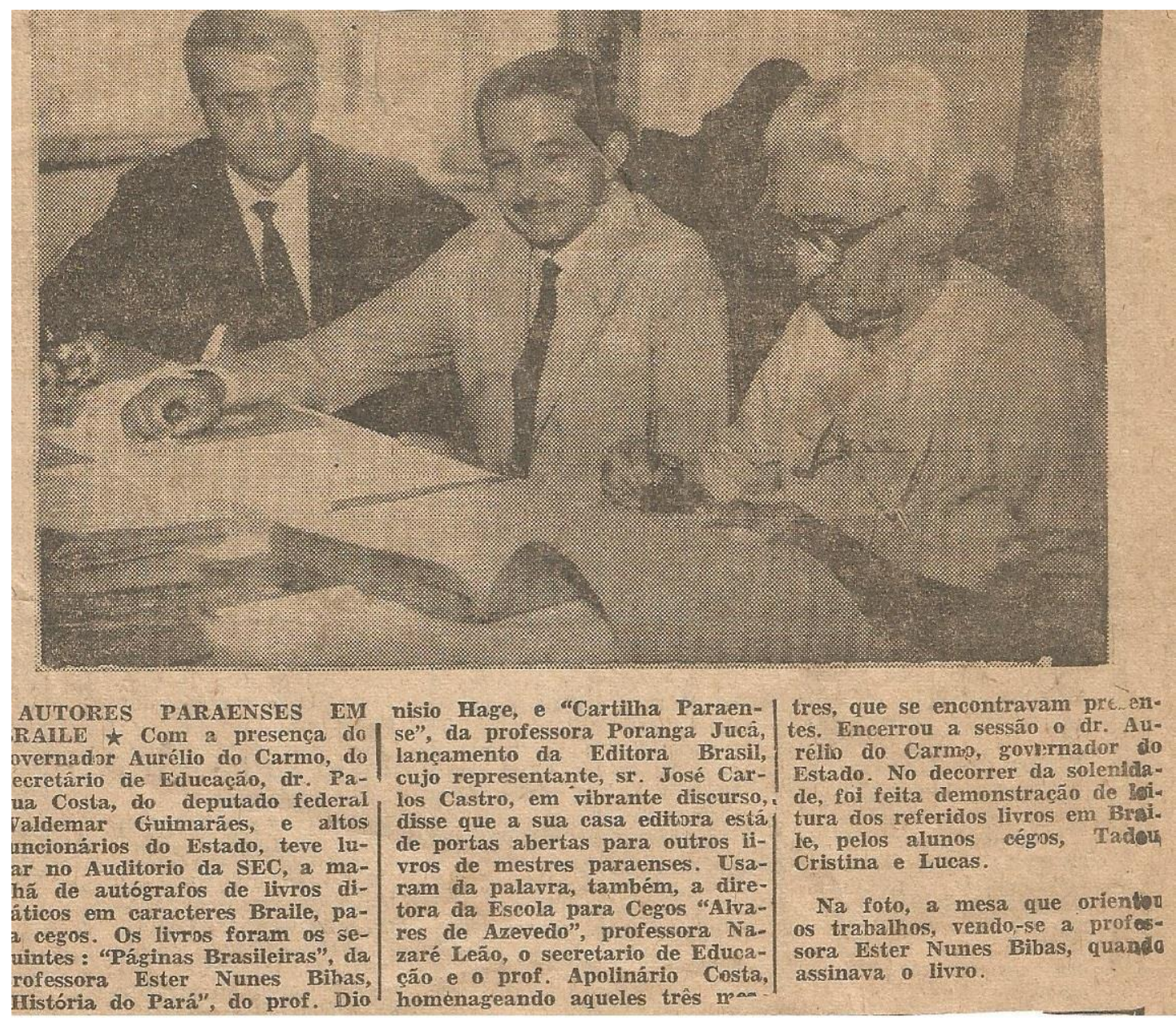

Fonte: Arquivo Familiar - Sílas Bibas - filho de Ester Nunes Bibas.

São informações, ainda que esparsas, trazem um olhar sobre a importância e o protagonismo de uma mulher na educação paraense e nessa percepção, o direcionamento para o processo de analise dos livros didáticos localizados desta autora, a partir do estudo material e discursivo dessa obra para identificar o pensamento educacional, traduzidos por seus enunciados textuais que revelam competências, habilidades, conhecimentos apreendidos e ou mobilizadas por esta educadora no exercício da docência, transcritos em seus textos para o alcance de uma a compreensão da atuação desta educadora como intelectual e como sujeito epistêmico, sujeito produtor e sujeito aprendente de saberes.

Num contexto profissional em que o aprender, incorpora e produz saberes. Trata-se, pois, segundo Tardif (2014) de "conhecimentos técnicos, saberes da ação, de habilidade de natureza artesanal, de caráter estritamente cognitivo ou de caráter discursivo". O que nos leva a apreender que independente de suas características ou natureza, os saberes produzidos pelos professores demonstram seu papel e seu lugar de intelectual de "peso" para campo 
educacional. Os saberes docentes referem-se à atividade educativa, às práticas pedagógicas, ao mundo escolar e para a formação dos demaisprofessores.

Todo o processo de produção de professores envolve outros sujeitos: a escritor(a), os professores, os alunos, sujeitos atuantes dos processos escolares, enquanto sujeitos concretos, participes do contexto, educacional, social, cultural, econômico, que ao se apropriarem de saberes culturais, tornam-se também sujeitos produtores de cultura, ainda que sob o controle social impingido pelas relações de poder presentes no ato de ensinar e do aprender.

Ester Nunes Bibas no seu transitar por diferentes caminhos foi imprimindo nesse transitar suas marcas e suas contribuições. Se revelando assim, um sujeito protagonista em diferentes áreas, do social, da poesia, da educação. No seu percurso de vida, construiu uma história particular e diferenciada, se comparada com a maioria das mulheres do seu tempo. Inserida num cenário histórico, que demarcava o lugar da mulher numa condição de subalternidade, e submissão. Ester Nunes Bibas em seu lugar social emerge de classes médias e ou "remediadas", mas diante da uma realidade societária tradicional que limita a inserção social das mulheres; Ester Bibas se enquadra entre as mulheres que ocupam duplas posições de subalternidade, seja como mulher, seja como escritora. Mas apesar dos condicionamentos culturais percebe-se que mesmo numa condição de sujeito subalterno, são mulheres que exerceram certa autonomia ao escrever e ao construir seu espaço de onde exercitaram a "fala" e se fizeram "ouvir" como mulheres intelectuais e atribuíram a seus escritos um sentido e um significado educativo e político para o seu tempo e para a sociedade em viveram. Nesse cenário histórico particular localizaremos as obras de Ester Nunes Bibas e nelas percebemos como as condições culturais de impossibilidades se transformam em condições de efetivas realizações. Entretanto, observa-se que tais experiências retratam histórias de mulheres que ficaram no passado, escondidas e apagadas da memória histórica, seja local, seja nacional e que precisam ser rememoradas e valorizadas para se obter uma compreensão da história, da educação a partir da percepção de sua atuação pedagógica e de seu poder de interferência na educação e na ordenaçãosocial. 


\section{IVANÁLISE MATERIAL DO LIVRO DIDÁTICO "PÁGINAS BRASILEIRAS" ESTER NUNES BIBAS}

O presente capítulo versa sobre o estudo, a análise material e apreensão da intencionalidade declarada ou circunscrita no aspecto material da obra didática "Páginas Brasileiras" de autoria de Ester Nunes Bibas.

Neste estudo, o compreender do recorte temporal em que se situa esta produção didática, ou seja, apreender o contexto histórico e educacional das décadas de 1950-1960 em que se dá a produção, a publicação e a circulação dos livros "Páginas Brasileiras", e ou outros contextos sinalizados pela obra.

O estudo dos exemplares desta obra didática apresenta a intenção investigativa de perceber as interferências da política educacional direcionada à edição de livros didáticos, matizados ou não pela perspectiva transformadora da educação nacional e seu direcionamento para a formação profissional dos educadores, para a renovação das práticas pedagógicas e dos sistemas de ensino. Um ideário de educação e de uma escola "nova" que transitou desde os primeiros anos republicanos nas décadas seguintes, em que são produzidos os livros "Páginas Brasileiras".

Uma visão de educação disseminada pela política de publicações do Centro Brasileiro de Pesquisas Educacionais, vinculado ao Inep - Instituto Nacional de Estudos e Pesquisas Educacionais e este ao Mistério da Educação. O Inep desde a década de 1930 e décadas seguintes, apontava para a centralização das Políticas Educacionais diante da situação da educação e da edição de manuais didáticos. Assim, a conformação do saber escolar e dos livros didáticos se tornaram ponto central da Política Educacional do Estado Novo.

A Criação da Comissão Nacional do Livro Didático - CNLD era vinculada ao Ministério da Educação, "encarregada entre outras funções, de examinar e autorizar o uso dos livros didáticos, que deveriam ser adotados no ensino "pré-primário, Primário, novas profissões e secundário de todo o país" (FILGUEIRAS, 2012, 166).

A CNLD se tornou instrumento institucional avaliador dos livros didáticos, das disciplinas escolares, seus conteúdos e seus usos pedagógicos endereçados à escolarização dos alunos e orientador das práticas pedagógicas ao longo da Segunda República Brasileira.

Segundo Xavier (2008), a partir das décadas de 1950-1960, o Inep apostava na produção de livros didáticos como instrumentos renovados que viessem promover novas práticas docentes pela disseminação de um olhar "racional" sobre realidade social brasileira em momento de modernização e pelo desenvolvimentismo do país. Embora momentos 
políticos diferenciados, mas que remetem para a educação um lugar de destaque na produção de saberes, momentos de expansão da escola e o acesso às classes populares para dar atendimento às necessidades de um mercado em expansão em que o saber e a qualificação para o trabalho tornaram-se foco da atuação escolar.

O livro didático se reveste de um direcionamento, de um sentido para o qual foi produzido e assim, apresenta-se como produção complexa, que sob o olhar de Choppin (2002, p. 18) se reveste de intelectualidade, de uma orientação pedagógica, de um objeto histórico, cultural e ideológico de um dado momento. São revestimentos que se expressam pelos aspectos materiais e intencionais; aspectos que revelam a cultura material escolar, suas concepções de educação, práticas e produção de conhecimento escolar.

A obra didático-pedagógica de Ester Nunes Bibas compunha uma coletânea de 05 livros didáticos destinados às cinco séries do ensino primário do estado do Pará, com edição impressa subsidiada por uma editora de renome, a Editora do Brasil S/A, com liderança nacional na edição de livros didáticos.

Ao empreender buscas em jornais, bibliotecas e arquivos, localizamos na Biblioteca Pública do estado do Pará apenas dois exemplares desta coletânea de livros didáticos. Um exemplar referente ao Terceiro livro destinado à terceira série do primário e outro exemplar digitalizado referente ao quinto ano do ensino primário. O que nos levou a perceber a ausência de preservação e guarda dos livros didáticos desta professora e desta forma a "perda" dos livros em sua materialidade física.

Apoiando-se nas observações de Xavier (2008, p. 72), os subsídios governamentais e a ação incisiva do Estado no processo de produção e publicação dos livros didáticos favoreceu o barateamento dos livros, o uso contínuo dos livros e assim tornaram-se fatores facilitadores para a aquisição dos livros em virtude da produção abundante de livros didáticos. Circunstâncias políticas que podem ter contribuído para a banalização, a desvalorização da importância histórica dessas obras didáticas e a dispersão de acervos didáticos e a inexistência de esforços consistentes para assegurar sua conservação. Fato recorrente no processo de apagamento da memória educacional brasileira e paraense.

Essa realidade nos levou a considerar como documento para o estudo e análise dos livros "Páginas Brasileiras" as cópias localizadas desses livros, sob a guarda da Biblioteca Pública do Estado do Pará, como fonte documental histórica e meio estratégico investigativo para a apreensão da materialidade impressa nos livros e estudo mais detalhados dos livros com a intencionalidade de compreender o Sistema Educacional Brasileiro e Paraense pela vinculação dos escritos e do pensamento da autora à filosofia, à política educacional e o 
pensamento intelectual da época que subsidiavam os parâmetros para a educação escolar no tempo e no contexto em que os livros "Páginas Brasileiras" foram produzidos e que atravessaram o pensamento e a produção educacional de Ester Nunes Bibas.

O estudo e a análise dos livros "Páginas Brasileiras" apresenta o propósito de apreender e compreender o pensamento educacional desta educadora-escritora de livros didáticos, em seus aportes epistêmicos, seus imbricamentos com o cenário histórico, social, cultural, educacional e outras falas de autores em que a autora estabelece associações. Obras, pensamentos, proposições que interferem e matizam os textos, os discursos enunciados pela autora, os sentidos e as intencionalidades em seus propósitos educativos. Informações, concepções e proposições subsidiadas em outras falas que mediam a produção textual da autora, na organização dos saberes e conteúdos escolares direcionados aos professores e alunos, sujeitos da educação escolar paraense.

A analise dos livros didáticos "Páginas Brasileiras" se pautou em autores que estudam a temática livro didático, entre eles, Roger Chartier (1990, 1998); Choppin (2002, 2004); Bittencurt (1990, 1993,1997); Décio Gatti Júnior (1998); Munakata (2012); Claudino (2014); Xavier (2008); Filgueiras (2012), autores vinculados à história cultural, como suporte teórico metodológico para uma estudo investigativo a partir da concepção do livro didático, enquanto objeto historicamente situado, e nesse sentido compreendido como um produto cultural imerso num momento histórico e num dado cenário sociocultural. Um objeto "complexo" por apresentar múltiplos formatos, diferentes funções, direcionar-se para diferentes níveis e modalidades de ensino e, ao se constituir um objeto multifacetado tornou-se produto no mercado editorial. Associando-se a essas observações, o presente estudo, destaca também o lugar da mulher intelectual paraense enquanto professora e autora de livros didáticos. Um sujeito historico atuante e veiculador de pensamentos, proposições didático-pedagógicas. Uma autora que apresenta uma fala escrita empenhada com a sua visão de educação e do contexto político-cultural em que se insere como mulher e educadora e contexto demarcador de sua proposta educacional. O livro Páginas Brasileiras, analisado enquanto objeto historicamente situado e revelador e simultaneamente produto da história da educação nacional e local.

O estudo desses livros didáticos num primeiro momento enfatizará a análise sobre a materialidade dos exemplares localizados, com a intensão de promover a visibilidade material do livro em seus detalhes de construção, impressão como marcas editoriais que sinalizam a apresentação da obra como objeto concreto, material disponibilizado ao consumo escolar. Enfatizando-se nesta análise a Capa, contracapa, sumário ou índice e detalhes impressos que revelam as singularidades dos livros. Nesta descrição material, a seleção de textos 
endereçados à leitura de autoria de Ester Nunes Bibas e de autores selecionados em seus aportes recorrentes e sinalizadores de conteúdos e de temáticas com sentidos políticos, ideológicos trabalhados e disseminados no contexto escolar no cumprimento do papel social da escola neste tempo histórico. Um sujeito histórico no âmbito da história da Educação.

Uma análise que enfatiza as características materiais impressas nos livros "Páginas Brasileiras”, assim como a análise discursiva dos gêneros textuais endereçados à leitura e a escrita. Inicialmente buscamos referencias de estudos já empreendidos sobre os livros didáticos, considerando-se as diferentes abordagens teórico-metodológicas.

\subsection{ESTUDOS SOBRE OS LIVROS DIDÁTICOS}

Chartier (1998), em sua obra A Aventura do livro do Leitor ao navegador entre outros aspectos, aborda a historia do livro e sua relação com os processos de leitura e escrita. Nesse recorte, aponta a história do livro marcada por grandes revoluções que perpassaram pela produção manuscrita, impressa e eletrônica. Momentos históricos que transfiguraram a "cultura escrita". Pois, desde a "revolução" de Gutemberg, o livro impresso quebrou a relação de proximidade com os autores de livros e seus escritos, na medida em que passou a envolver nessa produção outros atores vinculados à impressão e as leis do mercado editorial.

Os estudos sobre a história do livro estão diretamente interligados à edição impressa do livro, embora a existência de produções escritas estivesse presentes desde a inscrição em pedras, argilas e escritos em papiros e outras formas manuais que remontam aos povos e sociedades antigas que se inseriram na cultura escrita. Nessas produções, o registro documental sobre a língua, sobre a escrita, sobre a maneira de pensar, a história política e cultural, as leis e normatizações para a vida em sociedade, assim como a sua religiosidade, conquistas, invenções; registros que retratam o modo de ser e viver. No entanto, a produção impressa possibilitou maior status, circularidade e favoreceu apropriação do patrimônio cultural da humanidade.

A “invenção" de Gutemberg (1439) caracterizada pela criação de tipos móveis e pela modernização da prensa provocou mudanças no mundo da leitura e da escrita, pois o volume da produção impressa possibilitou a difusão de conhecimentos, o registro de posições e contraposições referentes à política, religião e à vida em sociedade no cenário histórico da Europa. As produções impressas, a partir de então, corroboraram para visibilizar as necessidades da modernidade renascentista pela oportunidade do registro impresso da voz dos grupos políticos, dos religiosos reformistas e ou dos grupos dissonantes à sociedade da razão, 
do pensar e do conceber o mundo moderno. Neste momento histórico marcado por mudanças de toda ordem, a "divulgação editada colocaria um fim aos escribas da Igreja que monopolizavam a escrita e sobre tudo a transmissão de conhecimentos” (SILVA, 2011).

Neste ambiente de circulação de novos saberes e dos processos educativos, o livro escolar assumiu seu lugar no rol dos livros impressos e circulados na sociedade europeia. Embora se observe que a educação, os processos de escolarização e a aquisição da cultura escrita foram reservados inicialmente aos grupos da elite e do clero; como grupos a serem preparados para exercerem a administração civil e religiosa. Com a ascensão da classe burguesa ao comando econômico e político, sua qualificação à cultura letrada se dá como condição necessária para exercer a administração econômica e subordinar os demais grupos da sociedade moderna. Nessa conformação societária emerge uma educação elitista que por séculos impediu o acesso de grande parte da sociedade à cultura letrada e a condição de acesso somente permitida pelas exigências da modernidade. Ainda assim, o acesso a uma aprendizagem e a um saber vigiado e autorizado aos grupos populares. No âmbito da formação escolar, os livros didáticos na análise de Choppin (2004) se constituíram além de instrumentos pedagógicos, se tornaram produtos referenciais de grupos sociais. Por intermediar os processos de formação, reproduziram e perpetuaram identidades, valores, tradições e culturas.

Os livros didáticos revestem-se de um objeto material e ao mesmo tempo de produto cultural situado num tempo e numa organização societária, na medida em que desempenham a função de veículo condutor da cultura, de saberes, de princípios, de condutas sociais e morais a serem apropriados. Tornando-se importante a fonte material documental para a apreensão da sociedade e da História da Educação em que se encontra inserido.

\footnotetext{
Primeiro, tratar-se de um tipo de material de significativa contribuição para a história do pensamento e das práticas educativas ao lado de outras fontes escritas, orais e iconográficas e, segundo, ser portador de conteúdos reveladores de representações e valores predominantes num certo período de uma sociedade que, simultaneamente à historiografia da educação e da teoria da história, permitem rediscutir intenções e projetos de construção e de formação social (CORREA 2000, p. 11).
}

A importância do livro didático e do letramento esteve associada à ampliação dos processos de escolarização, resultantes das exigências da modernização e do desenvolvimento econômico, que visualizavam o campo educacional como lugar de formação de saberes de acordo com as prerrogativas do mercado em expansão. A modernidade atribuiu ao Estado o papel de organizador da educação, das práticas educativas, do saber escolar, da produção, 
circulação dos livros didáticos e demais protocolos para a formação e para a preparação das camadas populares com a prerrogativa da construção do sentido de nacionalidade, como fator fundante da identidade do Estado moderno, como também para dar atendimento às demandas do mercado econômico em expansão.

No Brasil, o Livro didático ganhou maior expressividade no processo de expansão do sistema de educação nacional a partir dos meados do século XIX, na era imperial, possibilitando o acesso de grupos até então excluídos da educação elementar. A produção editorial de livros escolares se ampliou na Primeira República. A produção impressa de livros didáticos acompanhou a diversificação dos níveis de ensino implantados no país: o ensino elementar ou primeiras letras, o secundário e o superior, que passaram exigir uma produção de livros específicos por série, disciplinas e níveis de ensino.

Os primeiros livros impressos no Brasil se verificam com a instalação da Imprensa Régia em 1810 para atendimento imediato às necessidades da Corte portuguesa, no entanto a partir de então, o país com a criação de uma estrutura editorial paulatinamente vai produzindo textos impressos para além de documentos e registros oficiais e produzir a edição de livros. Tornando-se um marco na produção livresca no país pelo acolhimento de escritores lus0brasileiros. Considerando-se que anterior a esse feito joanino, os escritores brasileiros recorriam à impressão de suas obras em editoras estrangeiras principalmente de Portugal e da França.

Os livros escolares ou manuais escolares como eram denominados se referiam a uma variedade de títulos e formatos que ganharam materialidade em cartilhas, livros escolares, livros de leituras e outras produções no âmbito da religião e outros escritos que passaram a ser impressas e reeditadas pelas necessidades apontadas pela educação, pela sociedade e pelo consumo escolar sempre crescente. Nesse processo de expansão da produção livresca, em especial, os livros didáticos, pela função para além de veículo de conhecimentos, de cultura, de valores e normas de condutas, incorporou a função de bem de consumo, produto mercadológico da economia editorial.

Para Alain Choppin (2002), a temática relacionada à história do Livro didático e a cultura escolar vem atraindo o interesse de historiadores, educadores, sociólogos e pesquisadores do campo da linguagem e da linguística entre outros nas últimas décadas do século XX. Fato observado nos países europeus, Japão, Brasil, Argentina entre outros, onde o livro didático se tornou referencial para a atuação de professores e para os processos de aprendizagem dos alunos, ao assumir a função de instrumento pedagógico privilegiado para o desenvolvimento da leitura e da escrita. 
Seguindo as observações deste pesquisador francês, os estudos acadêmicos sobre os livros didáticos surgiram a partir da década de 1960, a partir de pesquisas que analisaram os conteúdos cívicos e ideológicos presentes nos textos de leituras e nos saberes disciplinares abordados pelos antigos livros escolares e, somente na década de 1970, os estudos investigativos passaram a revisitar os antigos "manuais" a partir da compreensão do livro como revelador da história, da educação e do processo de construção do saber escolar. Na década de 1980 se verifica a expansão dos estudos em vários países, onde o livro didático se tornou meio estratégico no processo de ensino e aprendizagem.

No Brasil essa temática passou a ser inserida como objeto de estudo por diferentes campos do conhecimento; o que possibilitou além da expansão, a renovação deste campo investigativo pela utilização de novas técnicas de análises e de armazenamento e tratamento destas fontes históricas. Estudos que se subsidiaram numa abordagem interdisciplinar que atravessa e ao mesmo tempo é atravessada pelo o campo da educação, da história, da cultura, da linguagem entre outros intercruzamentos disciplinares que produziu uma análise sob o foco da multiplicidade das funções desempenhadas pelo livro didático.

Segundo a avaliação da pesquisadora brasileira Circe Bittencourt (2004), as temáticas relacionadas ao livro didático tem despertado o interesse investigativo de biógrafos, educadores e intelectuais de várias áreas do conhecimento e o aumento significativo de produções a respeito desta temática. Interesse relacionado à relevância assumida pelos livros didáticos nos processos de letramento, aquisição de saberes, seu lugar na escolarização brasileira, sua relação com as práticas de ensino e aprendizagem dos alunos, Instrumento revelador do papel da escola brasileira a partir do século XIX; assim como, da história das editoras, da história da produção escolar, entre outros temas, então dominantes e referendados no processo de escolarização brasileira e paraense.

Nessa perspectiva, o livro didático se constituiu como fonte para se pesquisar o currículo, as disciplinas escolares, os saberes, práticas educativas e o pensamento educacional, político e cultural que atravessam as concepções e o fazer pedagógico de um dado momento. Nesta avaliação, a incorporação de uma análise complexa, que se envereda para a compreensão do "lugar" ocupado ou desempenhado pelo autor-escritor, pelos interlocutores da obra didática, professores, alunos, a sociedade, o livro e seus enunciados, impressos e expressos na materialidade do livro.

A abordagem histórica do livro didático promoveu uma apreensão deste gênero do livro, como objeto cultural contraditório, polêmico, complexo por se circunscrever para além dos processos de escolarização, ao se inserir num cenário de debates, críticas e abordagens 
inovadoras propiciadas por encontros acadêmicos, produções de artigos em revistas e produções de grupos de pesquisas entre outros estudos, que se ampliam e oportunizam uma apreensão do livro didático em sua complexidade. O que vem recolocando o lugar do livro didático como objeto de múltiplas leituras ou abordagens.

Nesse sentido, a obra de Choppin (2008) reforça a abordagem histórica nas análises dos manuais escolares enquanto fonte de pesquisa documental, pela ênfase dos estudos sobre seu suporte material, seus conteúdos, suas indicações didático-pedagógicas, atividades de memorização e apropriação do saber escolar, objeto mediador do ensino e da aprendizagem em sala de aula.

Alain Choppin (2004) apreende o livro didático como documento, fonte histórica reveladora da história do seu tempo, dos sujeitos, dos valores morais, da cultura e do papel da educação e da escola. Uma perspectiva centrada no estudo contextual em que a obra está circunscrita. O livro reflete e é refletido pelo ambiente cultural no qual, se dará à circularidade e o uso das proposições, conteúdos programáticos por professores e alunos na sala de aula.

Circe Bittencourt (1993), em sua tese de doutoramento traz uma abordagem inovadora em sua pesquisa, ao abordar o livro didático em suas diferentes dimensões; Como produto editorial, instrumento didático-pedagógico e portador de valores ideológicos. Esta pesquisa renovou e ampliou as análises sobre o livro didático pela incorporação de uma abordagem histórica para apreensão do currículo, seus conteúdos, as disciplinas escolares, a cultura escolar, das correntes epistêmicas, como apreensões subsidiadas pela história cultural, pela história do livro e da leitura

Contribuição importante para o campo de pesquisa sobre a temática do livro que dinamizou este campo para estudo de outras temáticas a partir da concepção do livro didático como objeto epistêmico e fonte histórica para a compreensão da história da educação.

No campo da História cultural, a complexidade do livro didático tornou-se ponto central pela emergência de estudos que perpassam pela utilização dos livros didáticos, seus direcionamentos, sentidos, conteúdos e seu referendo com relação às questões políticas, econômicas, editoriais, e do pensamento educacional corrente de seu tempo. Permitindo-se a visualização de sua materialidade. O que caracteriza o livro didático como um objeto, uma produção historicamente situada. Uma análise histórico-cultural que além da possibilitar a apreensão material, subsidia estudos e análise de conteúdo ou discursiva dos gêneros textuais apresentados, como base referencial para a compreensão do pensamento educacional ou epistêmico do autor-escritor de livros didáticos. 
Choppin (2002) no artigo "O historiador e o Livro escolar" retifica o papel do livro didático em transmitir às jovens gerações, os saberes, as habilidades e as maneira de ser, a partir de um dado campo de conhecimento ou de vários campos de saber, num dado momento histórico, julgados e indicados como "indispensáveis" para a manutenção das bases estruturantes da vida social. São indicadores de direção e sentidos e estão transcritos em palavras, imagens, disposição gráfica, cores e outros elementos que se encontram expressos na materialidade de um livro didático.

A produção e a edição impressa dos livros didáticos são frutos de escolhas de seus autores, editores em direta relação com as demandas do campo educacional e do contexto social, político e cultural. Constituindo-se o livro didático em um projeto educativo, político e cultural a executado no contexto escolar. Um projeto que apresenta uma intenção, uma direção política, epistêmica e cultural reveladas em sua estruturação material, na organização e disposição textual, na apresentação de temas e da linguagem imagética que determinam sua intencionalidade como instrumento didático- pedagógica, como produto mercadológico e como sistematizador das ideias, e do pensamento educacional de seu autor-escritor, então como meio articulador de outros saberes e pensamentos de outros autores, escritores e intelectuais, que substanciam o projeto enunciado pela fala e materializado pela escritura do autor. Entre diversas funções atribuídas ao livro didático, suas características materiais, tornaram-se elementos importantes em sua configuração como objeto "físico-material" de análise de seus protocolos de formatação relacionados à paginação, à impressão, à estruturação textual e de imagens; aspectos ressaltados na produção editorial quanto de elementos ou aspectos que interferiram no processo de produção, impressão e editoração dos textos e das proposições didáticas direcionadas ao consumo escolar.

O acabamento material de um livro, enquanto objeto concreto, não se dá pela ação neutra de sujeitos partícipes desse processo, mas pelo investimento intencional na produção deste objeto cultural, notadamente marcada pela ação conjunta de sujeitos historicamente situados e com posições ideologicamente definidas. Uma produção que estabelece uma estreita vinculação com grupos, instituições político-ideológicas que ancoram em pensamentos, em outras falas, em saberes, posicionamentos e valores culturais, religiosos, educacionais que referendam textos e conteúdos curriculares para serem ministrados pelos professores e apreendidos pelos alunos. Todo um processo que sinaliza e é sinalizado por gêneros textuais e imagéticos que refratam a sociedade, os processos educativos, a religiosidade e, as maneiras de ser estudante criança, jovem e ou adultos inseridos no sistema escolar. 


\subsection{O LIVRO DIDÁTICO NO ESTADO DO PARÁ}

Eidorfe Moreira (1979) publicou a obra “O Livro Didático Paraense” pela Imprensa Oficial em 1979, na qual relata o panorama editorial do livro didático no estado do Pará desde o início do século XIX ao início do século XX. O autor traz referências importantes sobre a produção de livros escolares locais, principalmente para o ensino primário. E nesse campo de produção livresca, o autor considera o estado do Pará em uma posição privilegiada se comparado com outros estados brasileiros.

\footnotetext{
Entre os setores culturais em que o Pará comporta um honroso confronto com o que de melhor existe no país inclui-se sem dúvida o setor das letras didáticas, pelo menos no nível de ensino que até pouco tempo se chamava "Primário". Surpreende até mesmo como, no obstante o baixo índice demográfico, as dificuldades de comunicação e outras condições desfavoráveis, chegando a atingir tal posição de relevo neste particular (MOREIRA, 1979, p. 11).
}

O autor destaca a posição paraense levando em consideração as dimensões geográficas e as próprias condições de ensino no estado do Pará no século XIX. Momento em que o estado e a capital paraense não apresentavam uma posição econômica privilegiada. Contexto econômico e social que torna mais "honrosa" a posição do estado do Pará com relação à produção didática de autores paraenses e impressos em Belém pela presença de editoras locais.

Nesse particular, esse autor faz o registro da primeira editora, Santos \& Menor em 1838 e, em se tratando de obras escolares, em 1858 ocorreu à edição da obra Compêndio da Língua Indígena Brasílica de Francisco Raimundo Correia de Farias.

Moreira (1979) destaca a publicação da Cartilha Imperial em 1840 de autoria de Felipe Patroni. No entanto, o mercado editorial paraense se diversificou a partir dos meados do século XIX, quando inúmeros grupos editorias, litografias, tipografias iniciam suas atividades na produção livresca no Pará: F.M da Silva 7 Cia, JB dos Santos 7 Cia, Livraria Clássica, Taveira \& Sena, Pinto Barbosa \&Cia, Loiola, Porto de Oliveira \& Cia, Livraria Escolar, além de outros editores de obras históricas, literárias e de outras naturezas, a Escola profissional do Estado e o Instituto Lauro Sodré. O que demonstra o dinamismo editorial pela pujança econômica do Estado e da cidade de Belém no período de expansão da produção da borracha.

O artigo "O Livro Didático no Pará" de autoria de Maricilde de Oliveira Coelho (2002), retrata o contexto escolar paraense nas últimas décadas do século XIX e nas primeiras décadas do século XX, foi marcado pela expressiva produção editorial e a circulação de 
autores paraenses destinados ao ensino primário. Coelho identificou neste período, que os autores de livros escolares eram homens professores e ou homens de letras e de outros saberes, referenciados pelas autoridades educacionais como escritores competentes no âmbito intelectual e dessa maneira tornaram-se credenciados para produzir livros para a formação escolar; Homens intelectuais que produziram discursos autorizados nesse momento para a educação no Pará.

Num período marcado pelo crescimento econômico local, pela vida social intensa, Belém se reveste do ideário de "Paris dos trópicos" no imaginário regional, que impunha ao poder público, a necessidade do letramento, da vida refinada e da vanguarda cultural, muitas firmas editoriais se fixam na urbe belenense para dar atendimento a produção e circulação de livros, com destaque aos livros didáticos pela criação dos grupos escolares e suas demandas pedagógicas.

Para Moreira (1979), os livros didáticos apresentam-se segundo os padrões pedagógicos e métodos de ensinos deste momento e refletem as condições sociais e econômicas de sua época. Os livros didáticos paraenses trazem um diferencial, a descrição e as ilustrações sobre a cidade de Belém, o que lhe impõe um valor histórico e documental, em especial os livros de leitura e de geografia por encenarem a vida cotidiana na capital. Os livros didáticos desse período comtemplam os aspectos normativos do ensino do nosso idioma e estabelecem uma relação com a leitura. Neste campo, a utilização de textos literários de autores paraenses e de outras regiões.

Este autor menciona a professora "Ester Nunes Bibas, (como) figura de realce nesse campo particular, viria muito depois, já na segunda metade do século (XX), fora, portanto, do período de abrangência deste trabalho", referente aos livros didáticos no estado do Pará (MOREIRA, 1979, p. 28).

Comentários que nas entrelinhas realçam a contribuição dos livros didáticos "Páginas Brasileira" no processo de leitura e sua efetivação mediada pela produção textual literária da autora e de autores. Uma prática já utilizada por autores de livros didáticos que antecederam a produção desta professora paraense.

Os livros didáticos paraenses referendados por Eidorfe Moreira (1979) e, Maricilde Oliveira Coelho (2002), são subsidiados pelo modelo reformista e progressista da educação, a partir dos ideários da modernidade, da República e de uma educação moral, cívica e patriótica.

No campo acadêmico identificamos dissertações e Teses que de alguma forma abordam a educação do Pará e a produção dos livros didáticos. Nessas produções acadêmicas, 
o estudo sobre a educação republicana se tornou central. Talvez pela guarda de registros históricos sobre essa temática nesta temporalidade. Na pesquisa encontramos quatro artigos acadêmicos; o primeiro referente ao Livro didático no Pará da Primeira república, de Maricilde Oliveira Coelho, 2002, USP, o segundo trata da Importância do uso de Livros didáticos regionais no ensino de Ciências no Estado do Pará de autoria de Dorielton Nunes Barbosa apresentado no III CONEDU, 2016 e terceiro refere-se a "Historiografia e Ensino de História: A produção didática regional e Local dos Estados do Pará e de Santa Catarina (19181932)" e o quarto artigo sobre "A História da Organização do Ensino Primário de Belém do Pará: 1937-1945”. Este último artigo se localizando numa temporalidade mais próxima ao cenário investigado pela presente tese.

O quadro abaixo retrata as produções acadêmicas sobre a educação no Pará e em particular, sobre o estudo de livros didáticos nos programas de Pós-graduação da UFPA, UEPA e outros programas. Estudos que situam a educação paraense e os livros escolares numa temporalidade recorrente aos fins do século XIX e início do século XX. Embora distanciados do período de produção e circulação dos livros: Páginas Brasileiras se tornaram importantes fontes de reflexão para a compreensão da educação, da formação dos professores e dos processos de escolarização no estado do Pará.

Quadro 1: Dissertações e Teses.

\begin{tabular}{|c|c|c|c|c|c|c|}
\hline $\begin{array}{l}\text { Programa de } \\
\text { Pós-Graduação }\end{array}$ & Título & Autor & Ano & Temática & Modalidade & Metodologia \\
\hline $\begin{array}{c}\text { Programa de Pós- } \\
\text { Graduação em } \\
\text { Educação. } \\
\text { USP-SP. }\end{array}$ & $\begin{array}{l}\text { A Escola Primária no } \\
\text { Estado do Pará. } \\
\text { (1920-1940. }\end{array}$ & $\begin{array}{l}\text { Maricilde } \\
\text { Oliveira } \\
\text { Coelho }\end{array}$ & 2008 & $\begin{array}{l}\text { A Escola Primária } \\
\text { no Pará. }\end{array}$ & Tese & $\begin{array}{l}\text { Analisa a cultura da } \\
\text { escola primária no } \\
\text { Brasil, em particular no } \\
\text { Pará. A partir do } \\
\text { conceito de cultura } \\
\text { escolar de Dominique } \\
\text { Júlia: normas, } \\
\text { legislações, expressos } \\
\text { em relatórios } \\
\text { governamentais, } \\
\text { decretos, portarias da } \\
\text { Instrução Pública. }\end{array}$ \\
\hline $\begin{array}{l}\text { Programa de Pós- } \\
\text { Graduação em } \\
\text { Educação } \\
\text { UFPA. }\end{array}$ & $\begin{array}{c}\text { A Formação de } \\
\text { Professores na } \\
\text { República no Pará. } \\
\text { (1900-1904). }\end{array}$ & $\begin{array}{l}\text { Rafaela Paiva } \\
\text { Costa. }\end{array}$ & 2011 & $\begin{array}{c}\text { A Educação na } \\
\text { Primeira } \\
\text { República no Pará. } \\
\text { (1900- } \\
\text { 1904). }\end{array}$ & Dissertação. & Análise documental do \\
\hline
\end{tabular}




\begin{tabular}{|c|c|c|c|c|c|c|}
\hline $\begin{array}{l}\text { Programa de Pós- } \\
\text { Graduação em } \\
\text { História Social da } \\
\text { Amazônia. } \\
\text { UFPA. }\end{array}$ & $\begin{array}{l}\text { Por uma História do } \\
\text { Livro e a Leitura no } \\
\text { Pará: O caso da } \\
\text { Guajarina, editora de } \\
\text { folhetos de cordel } \\
\text { (1922-1949). }\end{array}$ & $\begin{array}{c}\text { Geraldo Magela } \\
\text { de Meneses } \\
\text { Neto. }\end{array}$ & 2012 & $\begin{array}{c}\text { A editora } \\
\text { Guajarina e a } \\
\text { divulgação de } \\
\text { Cordel }\end{array}$ & Dissertação. & $\begin{array}{l}\text { Análise do cordel como } \\
\text { estratégico de leitura. } \\
\text { Análise a partir do } \\
\text { contexto da História do } \\
\text { livro. }\end{array}$ \\
\hline $\begin{array}{l}\text { Programa de Pós- } \\
\text { Graduação em } \\
\text { História } \\
\text { PUC- São Paulo. }\end{array}$ & $\begin{array}{l}\text { Um Viveiro de } \\
\text { Mestres: } \\
\text { A Escola Normal e a } \\
\text { Cidade de Belém do } \\
\text { Pará em Tempos de }\end{array}$ & $\begin{array}{c}\text { Raimundo } \\
\text { William } \\
\text { Tavares Júnior. }\end{array}$ & 2012 & $\begin{array}{l}\text { A Instituição da } \\
\text { Escola Normal em } \\
\text { Belém e sua } \\
\text { relação com os } \\
\text { movimentos } \\
\text { políticos }\end{array}$ & Tese & $\begin{array}{l}\text { Situa a Escola normal } \\
\text { em tempos de } \\
\text { Modernização } \\
\text { cidade de Belém e } \\
\text { analisa o papel } \\
\text { educacional, sua } \\
\text { estrutura curricular, o } \\
\text { ingresso dos alunos e } \\
\text { professores e a } \\
\text { caracterização étnico, } \\
\text { origem social das }\end{array}$ \\
\hline PPGED-ICED. & 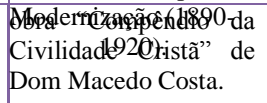 & & & $\begin{array}{l}\text { succicipialse } \\
\text { sobre clvildaade. } \\
\text { socioculturais. }\end{array}$ & & alunas normalistas. \\
\hline & & & & & & Análise discursiva da \\
\hline $\begin{array}{l}\text { Programa de Pós- } \\
\text { Graduação em } \\
\text { Educação- UFPA } \\
\text { Programa de Pós- }\end{array}$ & $\begin{array}{c}\text { A Ordem de Educar } \\
\text { meninos na Amazônia } \\
\text { Paraense: Uma análise } \\
\text { disckursiva da }\end{array}$ & $\begin{array}{l}\text { Raimunda Dias } \\
\text { Duarte. } \\
\text { Márcia Andréa }\end{array}$ & 2007. & $\begin{array}{l}\text { Análise dos } \\
\text { discursos } \\
\text { constituídos } \\
\text { A percepção da }\end{array}$ & $\begin{array}{c}\text { Tese } \\
\text { Dissertação. }\end{array}$ & 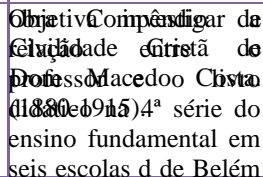 \\
\hline $\begin{array}{c}\text { Graduação em Letras- } \\
\text { UFPA. }\end{array}$ & $\begin{array}{c}\text { professor/livro didático } \\
\text { no Ensino- } \\
\text { Aprendizagem de } \\
\text { Língua portuguesa na } \\
4^{\text {a }} \text { série do ensino } \\
\text { fundamental. }\end{array}$ & $\begin{array}{c}\text { Almeida de } \\
\text { Oliveira. }\end{array}$ & & $\begin{array}{l}\text { relação instituída } \\
\text { pelo professor e o } \\
\text { livro didático em } \\
\text { escolas de Belém. }\end{array}$ & & $\begin{array}{l}\text { perceber as } \\
\text { estratégias criadas pelos } \\
\text { professores no uso do } \\
\text { livro didático. }\end{array}$ \\
\hline $\begin{array}{l}\text { Programa de Pós- } \\
\text { Graduação em } \\
\text { Educação- ICED- } \\
\text { UFPA. }\end{array}$ & $\begin{array}{l}\text { O que dizem os autores } \\
\text { sobre a formação } \\
\text { docente no Estado do } \\
\text { Pará. }\end{array}$ & $\begin{array}{l}\text { Euricléia do } \\
\text { Rosário } \\
\text { Galúcio. }\end{array}$ & 2014 & $\begin{array}{l}\text { Pesquisa pautada } \\
\text { em estudos de } \\
\text { autores, } \\
\text { legislações } \\
\text { relacionadas à } \\
\text { formação de } \\
\text { professores. }\end{array}$ & Dissertação. & $\begin{array}{l}\text { O que diz a legislação e } \\
\text { estudiosos sobre a } \\
\text { formação docente e } \\
\text { sobre a identidade } \\
\text { profissional } \\
\text { professor. }\end{array}$ \\
\hline
\end{tabular}

Fonte: pesquisas empreendidas pela autora em programas de Pós-Graduação.

São estudos que embora não referente o contexto histórico dos livros "Paginas Brasileiras", objeto de estudo desta tese, são referencias importantes e estudos pioneiros a respeito da Educação no Estado do Pará e em relação à análise de livros didáticos, ao referendarem a produção de livros didáticos de autores paraenses ou regionais, demonstrando a interligação da educação do Estado do Pará aos parâmetros da política educacional brasileira. Observamos que as pesquisas acadêmicas referidas no quadro $\mathrm{n}^{\circ} 1$ referendam estudos sobre a educação paraense no transitar dos fins do século XIX e primeiras décadas do século XX.

O que demonstra o necessário investimento em pesquisas acadêmicas, que venham elucidar a educação local e a produção didática paraense nos demais períodos históricos, de sobremaneira, a respeito da atuação e da produção de obras didáticas de professores e professoras paraenses que nomeiam as escolas públicas de Belém e do Estado do Pará. Uma 
lacuna a ser preenchida pela pesquisa acadêmica e ou pela pesquisa institucional pertinente ao campo da educação no Estado do Pará. Pesquisas que vislumbre o lugar protagonista do feminino na educação primária.

\subsection{A MATERIALIDADE DOS LIVROS DIDÁTICOS "PÁGINAS BRASILEIRAS"- TERCEIRO LIVRO (1967) E PÁGINAS BRASILEIRAS (SELETA), QUINTO ANO PRIMÁRIO (1957)}

A produção e a edição impressa dos livros didáticos são frutos de escolhas de seus autores, editores em direta relação com as demandas do campo educacional e do contexto social, político e cultural. Constituindo-se o livro didático em um projeto educativo, político e cultural executado no contexto escolar. Um projeto que apresenta uma intenção, uma direção política, epistêmica e cultural reveladas em sua estruturação material, na organização e disposição textual, na apresentação de temas e da linguagem imagética que determinam sua intencionalidade como instrumento didático- pedagógica, como produto mercadológico e como sistematizador das ideias, e do pensamento educacional de seu autor-escritor, então como meio articulador de outros saberes e pensamentos de outros autores, escritores e intelectuais, que substanciam o projeto enunciado pela fala e materializado pela escritura do autor.

Entre diversas funções atribuídas ao livro didático, suas características materiais, tornaram-se elementos importantes em sua configuração como objeto "físico-material" de análise de seus protocolos de formatação relacionados à paginação, à impressão e à estruturação textual e de imagens; aspectos ressaltados na produção editorial quanto aspectos que foram silenciados neste momento.

Como livro didático, a obra de Ester Nunes Bibas segue as orientações pedagógicas do momento em que é produzida, seguindo o critério de seriação e os conteúdos curriculares direcionados para os diferentes campos disciplinares, são atravessados por temáticas que apontam direcionamentos que demarcam pensamento educacional desta autora e suas vinculações políticas, epistêmicas, ideológicas.

Nesse processo de apreensão e compreensão da proposta didático-pedagógica de Ester Bibas para o ensino Primário subsidiaremos nosso estudo em dois eixos: Primeiro Eixo ou momento de apreensão da Obra Páginas Brasileiras. Estudar o livro em sua materialidade é inscrever este estudo num processo de análise a partir de elementos ou marcas editoriais impressas nos livros, observando-se a expressividade desses elementos como identificadores 
da obra, assim como captar o sentido das palavras, imagens que demarcam o grau de ensino, sua destinação, seu conteúdo e seus usos.

O processo de descrição material dos livros Páginas Brasileira objetiva dar visibilidade à produção educacional da professora Ester Nunes Bibas e os recursos didático-pedagógicos e sua fundamentação epistêmica, que são expressos pelo aparato material apresentados na estruturação de traços, imagens e textos que atribuem detalhes que enunciam e que retratam os livros didáticos de Ester Nunes Bibas. Considerando-se a dificuldade de acesso aos cinco livros de sua coletânea didática, apresentamos detalhes relevantes presentes nos dois livros produzidos por esta professora paraense entre a década de 1950-1960, então localizados.

Seguindo as observações acimas mencionadas, elaboramos um quadro de registros de marcas editoriais, para empreender o estudo sobre a materialidade dos livros "Páginas Brasileiras", respectivamente, o Terceiro Livro e Quinto Livro, com o objetivo de identificar as especificidades impressas nestes livros; assim como, possibilitar a visibilidade de elementos significativos presentes nesta edição que circularam nas escolas do estado do Pará entre as décadas 1950-1960 e que na atualidade, tais exemplares encontram-se sob a guarda da Biblioteca Pública do estado do Pará e distanciadas do público em geral.

Considerando que no processo de busca da coletânea didática de Ester Nunes Bibas sendo localizados dois livros de Páginas brasileiras (o terceiro e o quinto livro). Os exemplares encontrados se constituirão em fontes documentais para a análise material e a análise discursiva para a compreensão do Pensamento Educacional de Ester Nunes Bibas e sua inferência no cenário educacional paraense.

O Terceiro Livros de Páginas Brasileiras registra uma produção textual de autoria de Ester Nunes Bibas. São textos curriculares indicados para a terceira série do ensino primário, endereçados a crianças e adolescentes, segundo os conteúdos disciplinares para a série e nível de ensino.

O Quinto Livros de "Páginas Brasileiras" é destinado aos alunos do quinto ano primário e apresenta estruturação peculiar. Este livro se constitui em edição "seleta" de textos ou fragmentos de textos selecionados de autores brasileiros renomados, autores regionais e mulheres escritoras; livro publicado em 1957 pela Editora do Brasil S/A. São textos que apresentam um alto nível de erudição e transitam por diferentes gêneros e modalidades textuais. Emitem pensamentos, posturas, visão de homem, da educação, da escola, e de uma conduta alinhada com os preceitos morais, cívicos e religiosos.

A produção desta professora refere-se a uma coletânea didática composta por cinco livros didáticos para atendimento então, das 05 séries do ensino "primário" e observando-se 
os anos de reedição dos livros acima citados, há um distanciamento temporal de dez anos entre a edição do livro relativo ao Quinto Ano (1957) e o terceiro livro (1967), considerandose que os referidos livros compõem a mesma coletânea didática. Uma temporalidade que sinaliza a circularidade desta coletânea pela Editora do Brasil S/A, embora não registrado, o distanciamento da edição do Terceiro Livro e do Quinto Livro, nos levar a suspeitar de um número significativo de reimpressões dado a receptividade e circularidade do livro como produto didático e como produto mercadológico. Fato comentado pelo professor Clóvis Meira em texto publicado em homenagem aos cem anos de nascimento da professora Ester Nunes Bibas em 1988, no Jornal O Liberal e registrado no Livro de sua autoria intitulado "A Lira na Minha Terra" (1996), onde afirma ter manuseado um dos livros de Ester Nunes Bibas na $8^{\text {a }}$ edição.

O processo de descrição material dos livros Páginas Brasileira enfatizam a descrição e análise das marcas editoriais, enquanto sinalizações que publicizam os interesses editoriais, os propósitos trazidos pela coletâneia Paginas Brasileiras, quanto aos processos de formação escolar dos alunos, quanto às práticas pedagógicas dos professores do ensino primário. Entendendo-se que a materialidade do livro didático é que promove e embasa o projeto de educação e de ensino.

Seguindo as observações acimas mencionadas nos direcionamos ao estudo sobre a materialidade dos livros "Páginas Brasileiras", respectivamente, o Terceiro Livro e Quinto Livro, com o objetivo de apreender as especificidades impressas nestes livros; assim como, possibilitar a visibilidade de elementos significativos presentes nesta edição que circularam nas escolas do estado do Pará entre as décadas 1950-1960 e que na atualidade, tais exemplares encontram-se sob a guarda da Biblioteca Pública do estado do Pará e distanciadas do público em geral.

Um procedimento a ser descrito e analisado na seção 4.3.1 e 4.3.2, que correspondem ao estudo sobre a materialidade respectivamente do Terceiro e do Quinto Livro da Coletânea Páginas Brasileiras. Todo o estudo e interpreção material desses livros visando a apreensão de pistas, marcas, e indicadores para o estudo discursive a ser realizado no capítulo seguinte, que corresponde ao Segundo eixo de análise.

Nesse sentido, a análise de discurso dos gêneros textuais voltados para a leitura e a escrita da Língua Portuguesa, desvela o pensamento educacional de Ester Nunes Bibas, seus aportes subsidiares epistêmicos, ideológicos, educacionais, culturais, a serem trabalhados no capítulo $\mathrm{V}$ desta tese. Um processo de análise que se apresenta interligado ao aparato material dos livros em estudo. Nessa particularidade, busca-se uma compreensão desse objeto material 
e dos gêneros textuais, como elementos enunciadores dos conteúdos didático- pedagógicos mediados por generous discursivos, valores, sabers e condutas, indicados como prescrições para a atuação de professores primários e seus alunos, que se revelam nas palavras textuais, nas imagens, e atividades de aprendizagens a serem ministradas pelos professores e apropriadas pelos alunos. O que nos leva a apreender os objetivos, os sentidos e o direcionamento impetrado pelos livros de Ester Nunes Bibas no contexto de escolarização e nesse sentido como a proposição pedagógica desta escritora paraense ganha materialidade pela prática ou pela intervenção editorial de um grupo editorial com liderança nacional, numa cidade e num estado em que se tratando de produção intelectual e educacional, o reconhecimento da intelectualidade continuava sendo reservado aos homens.

\subsubsection{A Materialidade do Livro "Páginas Brasileiras"- Terceiro Livro}

Registramos inicialmente uma descrição dos elementos gerais impressos neste livro por direcionar o olhar para algumas marcas editoriais, que cumprem uma função de Para textos e como tal, suas inscrições imprimem sentidos e significados para a obra didática "Páginas Brasileiras"- Terceiro Livro.

Chartier (1998) em suas pesquisas identificou que os elementos que traduzem a materialidade do livro, são elementos que estão presentes tanto nos livros manuscritos quanto nos livros impressos e apontam singularidades que delineiam a estrutura do livro. A materialidade do livro se dá pela observância do códex, que norteia a organização estrutural do livro. Elementos materiais observados nos livros manuais quanto nos livros impressos:

Folhas dobradas um certo número de vezes, o que determina o formato do livro e a sucessão dos cadernos. Estes cadernos são montados, costurados uns aos outros e protegidos por uma encadernação. A distribuição do texto na superfície da página, os instrumentos que lhe permitem as identificações (paginação, numerações), os índices e os sumários [...] Há, portanto, uma continuidade muito forte entre a cultura (estrutural) do manuscrito e a cultura do impresso (CHARTIER, 19987, p. 7, 9).

Como elementos gerais trazidos pelas marcas editoriais que identificam e expressam a singularidades de um livro e as marcas da empresa editorial. Seguimos este olhar para observar, conhecer e compreender a produção didática de Ester Nunes Bibas, a partir da elaboração de um quadro síntese sobre elementos editoriais e materiais presentes neste Terceiro Livro da coletânea "Páginas Brasileiras". Como aspecto importante para a revelação desta obra didática e seus propósitos educativos para sistema de ensino do Estado do Pará. 
Quadro 2: Descrição Material do Terceiro Livro.

\begin{tabular}{|c|c|}
\hline Aspectos Materiais & Descrições \\
\hline 1.Formato do livro & $\begin{array}{l}\text { Traz um formato retangular, com a dimensão de } 14,00 \text { X } 20,00 \mathrm{~cm} \text {. Considerado em } \\
\text { tamanho pequeno, mas de fácil manuseio por endereçados à crianças e jovens. }\end{array}$ \\
\hline 2.Cores & $\begin{array}{l}\text { Este exemplar por se constituir uma cópia do original, seus detalhes nas imagens e outro } \\
\text { tipo de registro originalmente coloridos, apresentam-se em preto e branco. }\end{array}$ \\
\hline 3.Paginação & O livro contém 157 páginas \\
\hline 4.Tipo de encadernação & $\begin{array}{l}\text { Embora não registrado pela editora, o livro pelo seu formato e Impressão aponta para } \\
\text { uma encadernação do tipo Brochura. }\end{array}$ \\
\hline Editora & Editora do Brasil S.A Ano: 1967 \\
\hline 5. Autora & $\begin{array}{l}\text { Sem informações impressas a respeito da trajetória e sobre o lugar desta Professora } \\
\text { escritora no cenário educacional. }\end{array}$ \\
\hline $\begin{array}{l}\text { 6.Organização } \\
\text { imagens e ilustrações }\end{array}$ & $\begin{array}{l}\text { eO livro apresenta uma diversidade de textos. Textos para leitura e aprendizagem da } \\
\text { língua portuguesa; nestes, a presença de textos pátrios, religiosos, morais pautados } \\
\text { em valores, princípios, e condutas aceitáveis, textos sobre a região e a vida } \\
\text { amazônica, textos que explicam os conteúdos de História do Brasil, de Geografia, } \\
\text { matemática e Ciências Naturais. } \\
\text { Na maioria dos textos são indicados exercícios para serem realizados pelos alunos. } \\
\text { Os textos presentes neste terceiro livro do ensino primário não são extensos } \\
\text { considerando o próprio formato do livro. } \\
\text { Estes textos são escritos em prosa, poesia e assumem o formato de pequenas } \\
\text { histórias, cenas da vida em Belém, a comunhão religiosa e noções de hábitos } \\
\text { eugênicos a serem incorporados pelos alunos. Os textos sobre a região é bem } \\
\text { representado nesta obra. }\end{array}$ \\
\hline
\end{tabular}

Fonte: Quadro elaborado pela autora como dispositivo para a análise do Terceiro Livro "Páginas Brasileiras".

Este exemplar chegou para a guarda na Biblioteca Pública do Pará- Arthur Vianna na condição de reprodução de uma cópia do original. Nessa materialidade, de certa forma minimizaram uma percepção mais acurada sobre a materialidade impressa nesta obra, 
principalmente em relação à capa e outros detalhes em cores. Observamos a ausência de páginas e registros de apresentação do livro e da autora. No entanto, os dados acima descritos são detalhes importantes por registrarem as especificidades materiais deste livro.

O livro apresenta uma dimensão de 14X20 cm, que lhe outorga um formado de um pequeno livro, se comparado com as dimensões dos atuais livros didáticos. O livro se adequa ao olhar da empresa editoria em reduzir custos, garantir maior número de impressos e um pequeno formato que possibilitou o fácil manuseio do livro pelas crianças, adolescentes e adultos, sujeitos estudantes "pretensos" deste momento, para os quais o livro é direcionado.

O livro reúne 157 páginas para contemplar os conteúdos de diferentes áreas disciplinares, através de textos, anotações, imagens e orientações de exercícios direcionados para os alunos. Os textos e ou os conteúdos disciplinares são relativamente pequenos e encampam diferentes gêneros textuais: prosa, poesia, lendas, estórias, em que alguns são ilustrados com imagens, em sua maioria constituída por desenhos. O primeiro texto trazido pela autora na página 07 difere dos gêneros textuais citados, por se constituir em um "protocolo" de orientação para os alunos, o qual adverte o aluno para sua condição estudantil, mediante dez tópicos enumerados no texto "Mandamentos do Estudante". Ensinamentos prescritivos baseados em normas e princípios a serem seguidos para a adoção de condutas positivadas e referendadas pelo respeito e pela obediência a Deus, à Pátria e à Escola.

Como mencionado anteriormente, os textos selecionados para a leitura e a escrita dos estudantes perpassam por diferentes temáticas que transitam pelo campo da moralidade, valores, religiosidade, a vida cotidiana em Belém e na região como valorização do regionalismo como aspectos da realidade social mais próxima do aluno. Assim como outros textos no âmbito da História, da geografia, da matemática e das ciências naturais. Disponibilizaremos na figura 2 , um conjunto de textos que expressam os conteúdos abordados pela autora de Páginas Brasileiras, seus sentidos e sua intencionalidade na formação de crianças, adolescentes e adultos.

O contexto temporal desta obra se situa entre as décadas de 1950-1960, observando-se sua edição datada em 1967, embora não registre o número de edição deste exemplar. Mas comparando-se a data de publicação do Quinto livro em 1957 e um intervalo de 10 anos das publicações citadas. 
Figura 6 - Segunda Capa do livro Páginas Brasileiras, Terceiro Livro.

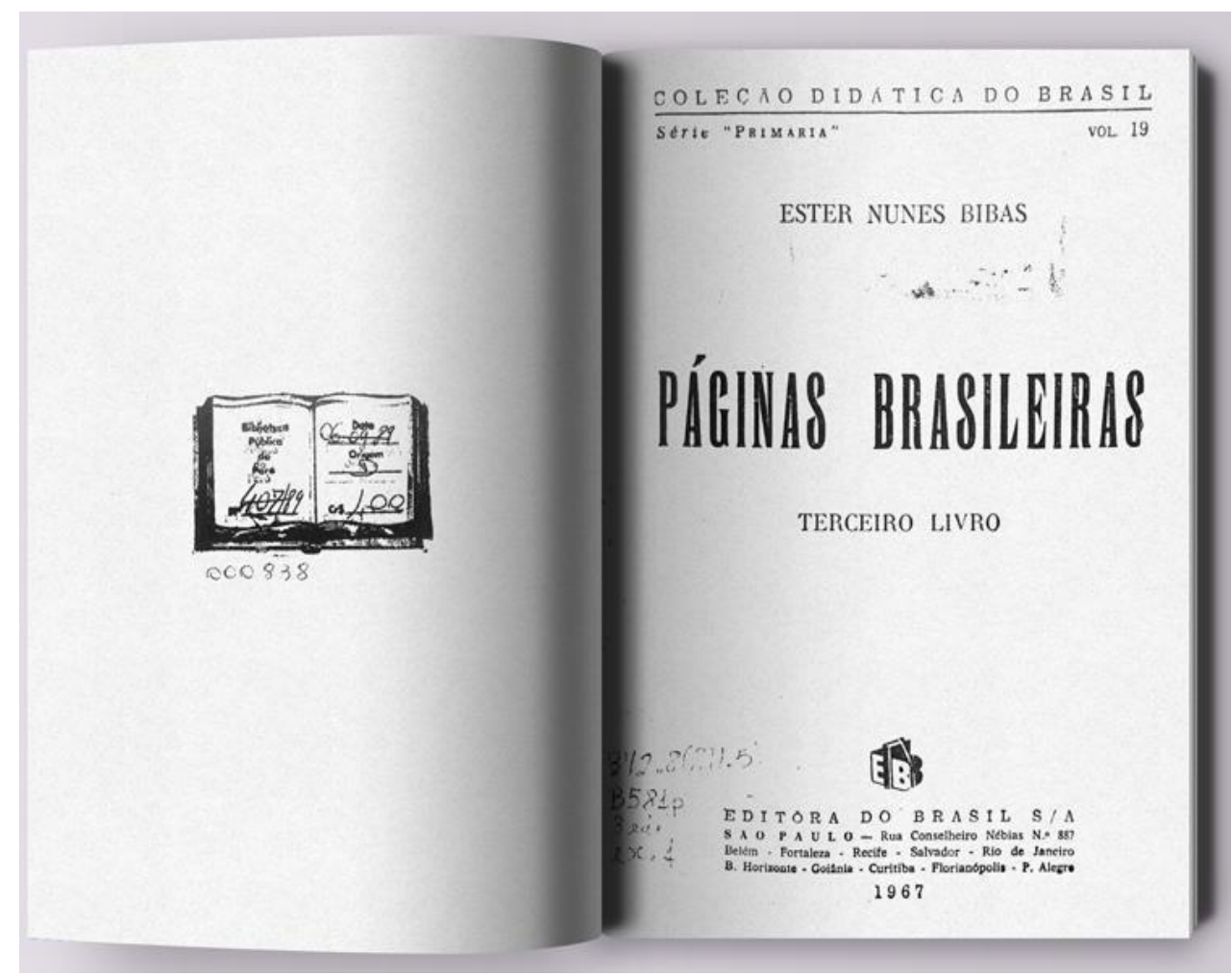

Fonte: Pesquisa de Campo, Fac-símile da obra da Biblioteca Estadual Gaspar Viana, Belém-Pará.

Esta capa na verdade corresponde a segunda capa do livro Páginas Brasileiras Terceiro Livro, considerando-se que o exemplar sob a guarda da Biblioteca Pública do Pará não apresenta a primeira capa. Nesta capa de rosto, alguns detalhes chamam atenção como a ênfase ao título do livro "Páginas Brasileiras", centralizado e com fonte que se destaca sobre as demais informações. O título é chamativo pelo significado que enuncia. Um livro brasileiro que poderia ser inserido no contexto nacional, ou seja, uma circulação ampliada para além do espaço regional. Outro aspecto importante que delineia e reforça o lugar ampliado desta obra e a sua inclusão como parte da Coleção Didática do Brasil, série Primária, volume 19, da Editora do Brasil S/A. Supomos que tais marcas referenciais estejam registradas a partir do interesse mercadológico da Editora do Brasil, ao colocar os livros de Ester Nunes Bibas, enquanto produção regional no cenário nacional pela força e pela atuação desta editora no cenário editorial do País. Sobre a editora do Brasil é retratado a presença editorial desta empresa em São Paulo e com representações em várias capitais brasileiras, como Belém, Fortaleza, Recife, Salvador, Rio de Janeiro, Belo Horizonte, Goiânia, Curitiba, Florianópolis e Porto Alegre. Uma presença que demarca seu poder e controle editorial de norte a sul do país, o que lhe assegura neste momento a liderança no mercado editorial de livros didáticos nacionais e regionais sob o foco da educação moral e cívica. 
As referências sobre este livro realizadas pela Biblioteca Pública do Estado do Pará Arthur Vianna estão registradas sob o $\mathrm{n}^{\circ} 372.8$ (811.5) B5 81p e seu recebimento ocorrido em 06/09/1989, sob o registro de $n^{\circ}$ 407/89 na Secção de Obras do Pará. Observa-se que neste registro é atribuído o valor de venda do livro em CR \$ 1.00. Considerando-se a moeda corrente neste momento. Ou seja, um valor atribuído em 1989, que demonstra um (des) valor mercadológico, possivelmente por ter se tornado com o passar do tempo e das mudanças didático-pedagógicas, uma obra obsoleta.

Ainda sobre a guarda deste exemplar, esta somente ocorreu 17 anos após o falecimento da autora Ester Nunes Bibas, ocorrido em 1972. O que demonstra a difícil localização dos demais livros que compõem a coletânea escrita por esta autora paraense.

Este livro didático é direcionado para a $3^{\mathrm{a}}$ série do ensino primário e por sua formatação expressa pelas marcas estruturais visíveis nas cópias desse livro nos apontam que se tratava de um livro pequeno em suas dimensões, mas aborda diferentes conteúdos disciplinares indicados para o terceiro ano do ensino primário. Neste formato, os textos presentes nesse terceiro livro são curtos, especialmente os direcionados à leitura e a escrita. Em grande parte, os textos contemplam vocabulários, indicam conteúdos e alguns apresentam exercícios direcionados aos alunos.

Figura 7 - Índice do livro Páginas Brasileiras.

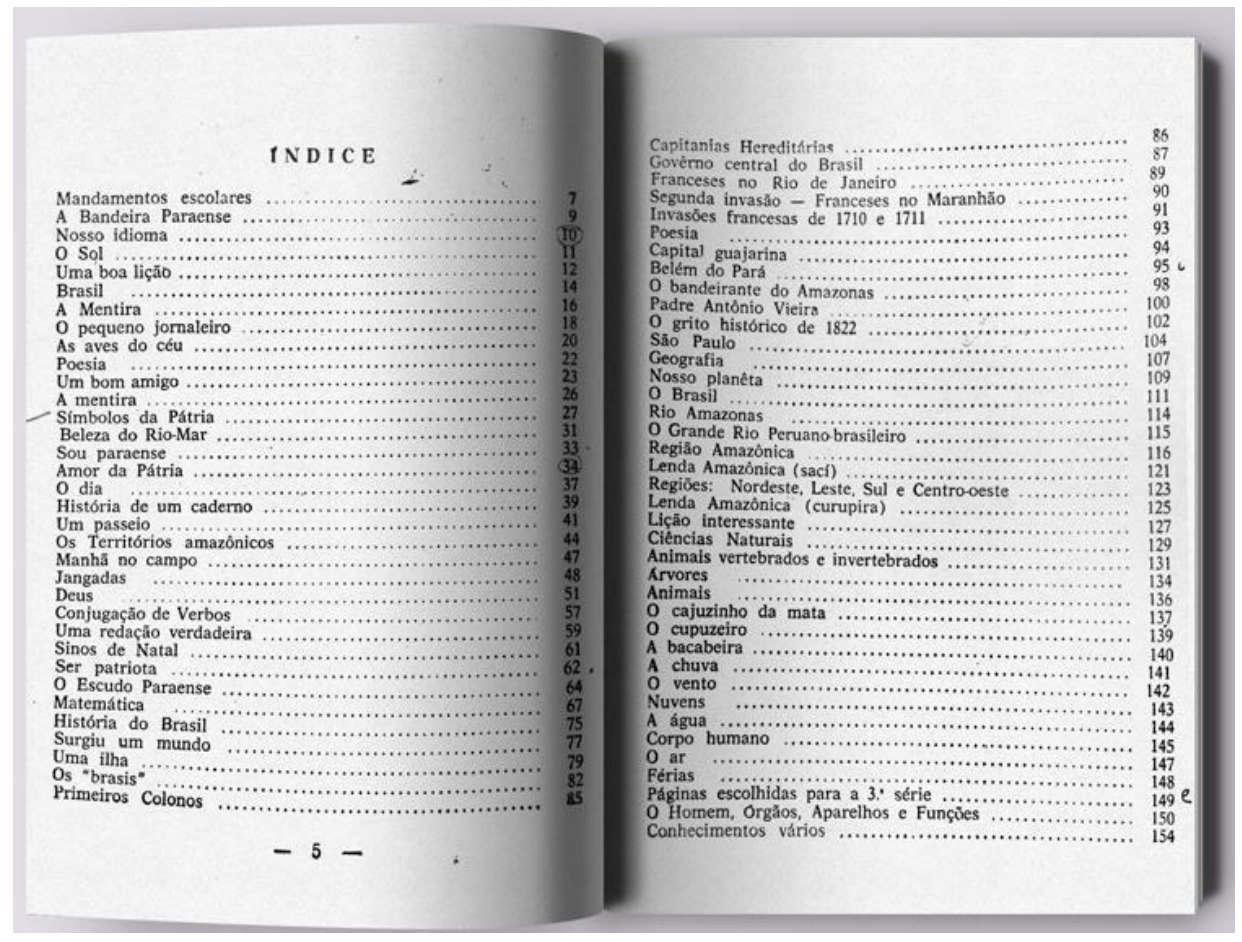

Fonte: Pesquisa de Campo, Fac-símile da obra da Biblioteca Estadual Gaspar Viana, Belém-Pará. 
Quadro 3: Descrição de Áreas, Gêneros e Temas do Livro.

\begin{tabular}{|c|c|c|c|}
\hline Área disciplinar & Gêneros Textuais & Temas recorrentes & Sujeitos pretensos \\
\hline $\begin{array}{l}\text { Texto de } \\
\text { apresentação }\end{array}$ & Texto normativo (1) & $\begin{array}{l}\text { Os mandamentos do estudante (normas e } \\
\text { condutas). }\end{array}$ & $\begin{array}{l}\text { Alunos e professores do } \\
\text { ensino primário }\end{array}$ \\
\hline Leitura/escrita & $\begin{array}{l}\text { (23) Textos } \\
\text { - Prosa: } \\
\text { poesia, } \\
\text {-oração } \\
\text { - textos narrativos } \\
\text { Textos descritivos } \\
\text { Fábulas } \\
\text { Textos sobre a realidade } \\
\text { regional }\end{array}$ & $\begin{array}{l}\text { Ser bom aluno; Estudar,combate á mentira } \\
\text { e maus hábitos e condutas. } \\
\text { Brasilidade- amar à pátria, seguir os bons } \\
\text { exemplos. } \\
\text { Símbolos nacionais Amizade Os textos } \\
\text { apresentam o formato de pequenas estórias } \\
\text { sobre a vida escolar, cenas da vida em } \\
\text { Belém, a comunão religiosa, hábitos } \\
\text { eugênicos a serem incorporados pelos } \\
\text { alunos. } \\
\text { O respeito aos mestres, à escola à Pátr } \\
\text { obediência as normas morais e religiosas. } \\
\text { Noções gramaticais: Língua portuguesa }\end{array}$ & \\
\hline Matemática & $\begin{array}{l}\text { Resoluções de Problemas } \\
\text { e expressões }\end{array}$ & $\begin{array}{l}\text { As quatro operações } \\
\text { Sistemas de medidas } \\
\text { Sistemas de capacidade } \\
\text { Sistema de Peso Frações } \\
\text { Moeda corrente }\end{array}$ & \\
\hline $\begin{array}{l}\text { História do } \\
\text { Brasil/ história } \\
\text { do Pará. }\end{array}$ & $\begin{array}{l}\text { Apontamentos sobre a } \\
\text { história do Brasil e } \\
\text { história do Pará, text } \\
\text { Belém do Pará. } \\
\text { Os Jesuítas }\end{array}$ & $\begin{array}{l}\text { O Brasil, O Pará, amor á patria pelo viés da } \\
\text { história dos 'heróis nacionais e religiosos. } \\
\text { Descobrimento do Brasil, } \\
\text { Os primeiros habitantes } \\
\text { Invasões Francesas } \\
\text { Fundação de Belém } \\
\text { Os bandeirantes do Amazonas }\end{array}$ & \\
\hline
\end{tabular}




\begin{tabular}{|l|l|l|l|}
\hline & Padre Antonio Vieira. & & \\
\hline Geografia & $\begin{array}{l}\text { Noções de geográfia } \\
\text { física, do Brasil, da } \\
\text { região. }\end{array}$ & $\begin{array}{l}\text { Planeta Terra, as capitais brasileiras, as } \\
\text { regióes brasileiras }\end{array}$ & \\
\hline Ciências & $\begin{array}{l}\text { Animais amazônicas } \\
\text { invertrebados, } \\
\text { As árvores, } \\
\text { Os fenômenos da } \\
\text { natureza. } \\
\text { O Corpo humano }\end{array}$ & Ênfase aos animais e árvores regionais. & \\
\hline
\end{tabular}

Fonte: Estudo dos Livros Páginas Brasileiras - Terceiro Livro.

Os conteúdos abordados são direcionados para os diferentes campos disciplinares. Pelo formato e dimensão do livro, os conteúdos disciplinares são organizados em textos curtos, especialmente os textos direcionados á leitura e a escrita. Ao final dos textos segue a sinonímia dos vocabulários e dependendo do campo disciplinar, são ministrados os conteúdos específicos e alguns destes textos indicam atividades a serem trabalhadas pelos alunos no sentido de exercitar a aprendizagem dos saberes ministrados.

Observa-se que o livro segue um direcionamento em termos de nivelamento dos conteúdos e a ministração das aulas, que são estruturados a partir do nível de ensino e a seriação em que os alunos se encontram. Critérios predominantes da organização curricular seriada presentes na legislação educacional brasileira a partir da Primeira República (18891930). A Educação Republicana.

A Reforma da Educação em 1930, proposta pelo Ministro da Educação e Saúde, Francisco Campos na Segunda República (1930-1937), não alterou a estrutura do Ensino Primário embora tenha ocorrido o retorno do Ensino Religioso católico. Momento em que a educação e a Saúde ascendem ao estatuto de política pública no país. Neste período, a Constituição Brasileira de 1934, estabelece a gratuidade e a obrigatoriedade do Ensino Primário. Destinado às crianças, aos adolescentes e aos adultos. Com vistas à formação de uma consciência patriótica e humanista dos alunos dos diversos níveis e modalidades de ensino. 
A partir da instituição do Estado Novo em 1937, a Educação tornou-se esfera estratégica para a formação do cidadão brasileiro em meio às mudanças de uma sociedade agrária e sua modernização para tornar-se urbano-industrial. A Educação se potencializa para a disseminação do nacionalismo patriótico. Com essa intencionalidade, institui-se uma Educação centrada na Moral, no Civismo e num cerne de uma Política conservadora nos currículos escolares. Uma educação cumpridora de uma missão reformadora do povo brasileiro diante de uma política desenvolvimentista 'ultra' nacionalista. Ainda que, instituída em meio aos discursos da "escola nova" defendida como "dinâmica e instrumental" para responder a uma formação de qualidade.

A Constituição de 1946, promulgada em 02 de janeiro, traz alterações para o ensino primário, que passou a ser dividido em ensino primário fundamental e o ensino primário supletivo. Uma expansão escolar do nível primário para atender uma demanda crescente e combater o analfabetismo diante das exigências desenvolvimentistas.

A preocupação em relação à organização dos livros didáticos se faz presente nas proposições técnicas do Inep - Instituto Nacional de Estudos Pedagógicos na década 19501960. Traz como intensão central, a efetivação de Políticas de Educação sob o foco da transformação social. E que viesse orientar as escolas para as exigências do desenvolvimento econômico e social que o Brasil vinha experimentando e que sinalizava uma educação prática ou pragmática e desenvolvimentista. Nesse momento de modernização e vida urbana, o livro didático surge como caminho eficaz para a qualificação de escola e dos processos de ensino.

A realização de Campanhas Nacional do Livro Didático é fruto da proposta de renovação do sistema de ensino brasileiro e nessa proposição, a busca da qualidade do material escolar produzido no Brasil, em especial, os livros didáticos que deveriam atender as necessidades nacionais e regionais. Embora os órgãos de acompanhamento de produção, circulação e distribuição dos livros didáticos surgirão somente nos anos finais da década de 1960.

No entanto, nos momentos de modernização e de expansão do sistema de ensino, os livros didáticos, segundo Choppin (1998), transformaram-se em "poderosas ferramentas de unificação - até de unificação nacional, linguística, cultural e ideológica". Pelos diferentes funções e proposições assumidas pelos livros didáticos, funções identificadas por este pesquisador, como referencial ou curricular, por circular no âmbito da cultura escolar, conteúdos e saberes; como instrumental didático-pedagógico, por instrumentalizar as práticas educativas dos docentes e os processos de aprendizagem dos alunos; Tornou-se meio estratégico para a circulação de ideias, conhecimentos e valores sociais, culturais, religiosos e 
políticos, formadores e formatadores do pensar, do agir e de ser, segundo os direcionamentos ideológicos dominantes. Cumprindo um papel decisivo para o disciplinamento dos indivíduos segundo as exigências do Estado, da Educação e do mercado em expansão. O livro didático se revestiu de uma função documental, por revelar o contexto histórico, social, cultural, que autorizam seus conteúdos e temas reveladores de um projeto de sociedade e de educação no momento histórico de sua produção e circulação.

Figura 8 - Organograma de intencionalidades do livro Páginas Brasileiras.

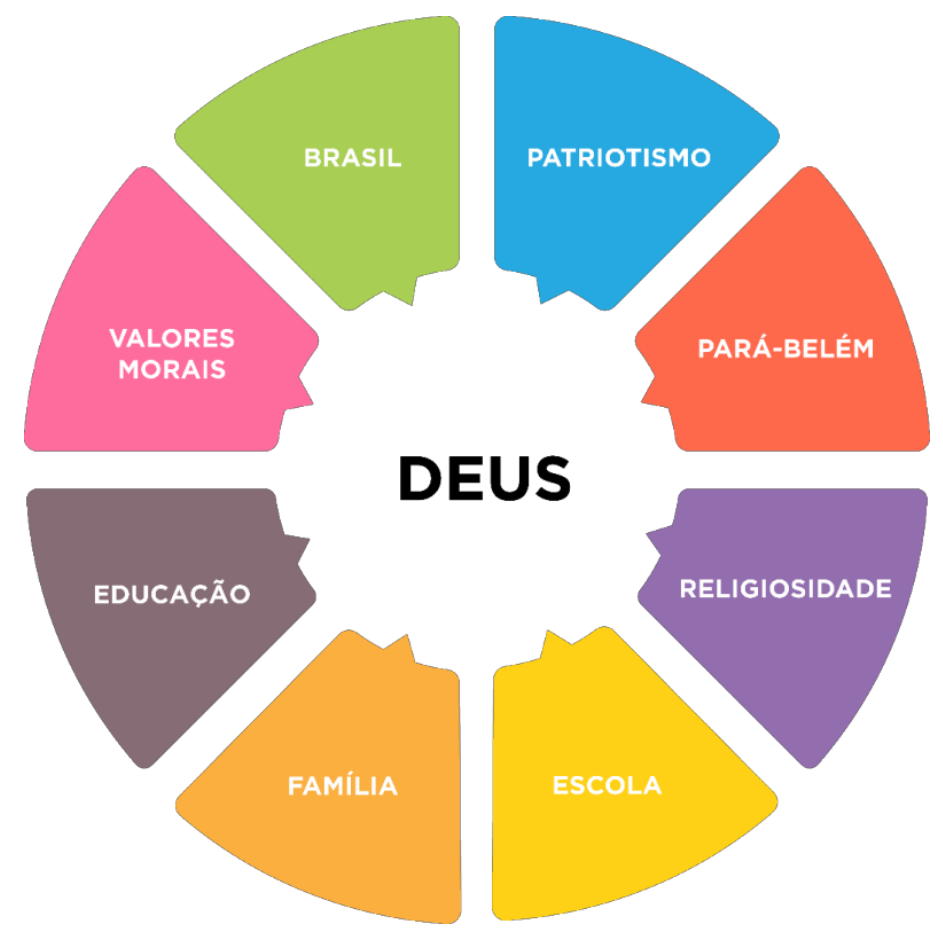

Fonte: Dados da Pesquisa de Campo.

Como já mencionado anteriormente, a produção textual neste Terceiro Livro perpassa por diferentes gêneros textuais. Sendo observados, textos religiosos, pátrios e textos sobre a cotidianidade belenense e sobre a cultura paraense e regional. São produções textuais, predominantemente injuntivos, prescritivos de condutas e atitudes positivadas para o combate dos maus hábitos, dos comportamentos vistos como inadequados e nesses moldes, direcionados para a formação e a reformulação do indivíduo e da sociedade pelo viés da educação. As temáticas recorrentes nas produções textuais encontram-se registradas abaixo: 
Figura 9 - Gêneros textuais do livro Páginas Brasileiras.

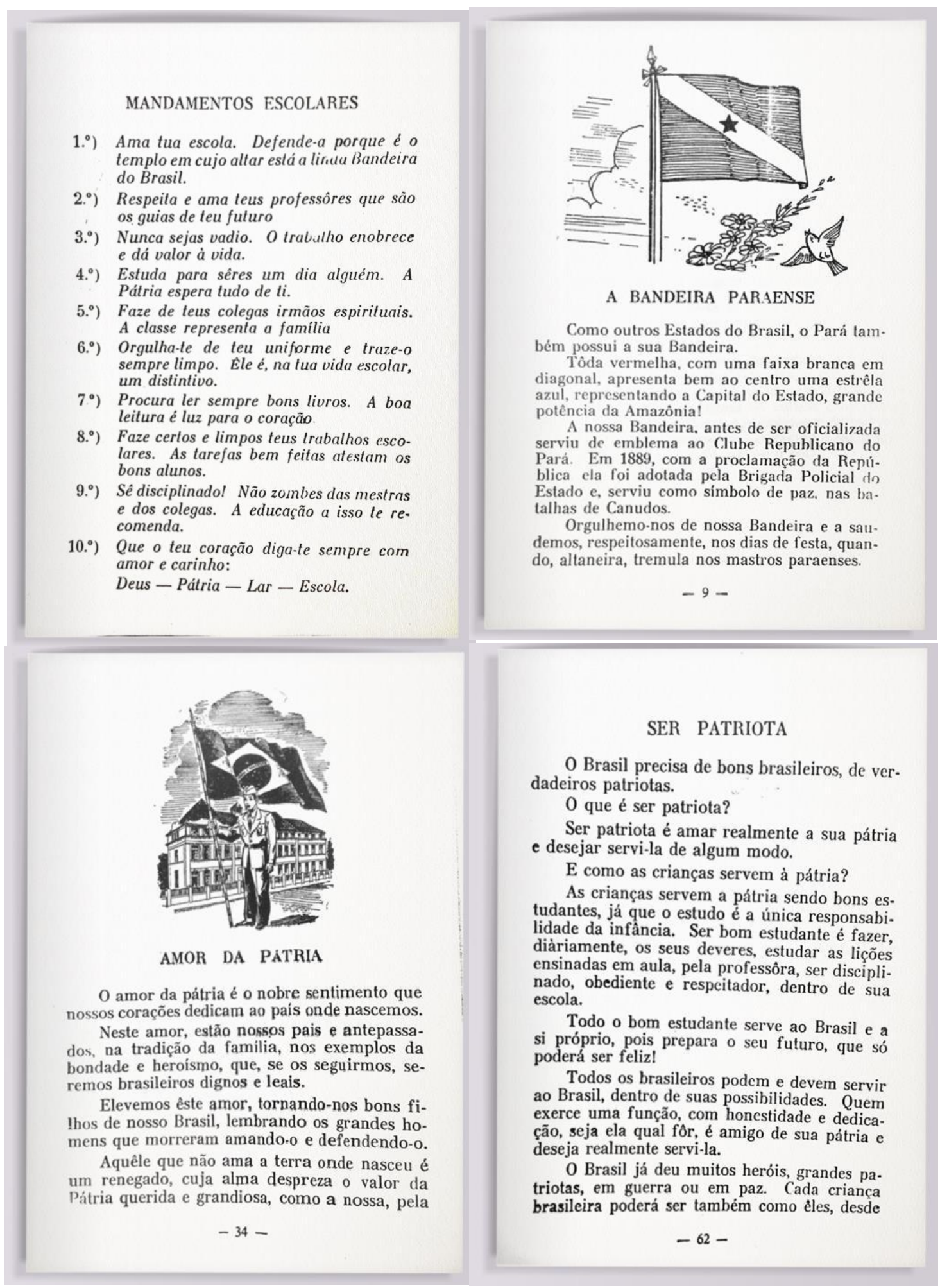




\section{SOU PARAENSE}

Sou moreno paraense de Belém do meu Pará, Belém, cidade bonita que sempre risonha está.

Sou portanto da Amazônia a terra dos seringais que se levanta orgulhosa do perfume de rosais.

Sou caboclo, não importa e sou moreno do Norte, bem moreno de verdade mas sou valente, sou forte.

Trabalho sempre contente, canseira nunca senti! Recebo o ar matinal almoço e tomo açaí.

A noite vou estudar e procedo sempre bem, e assim jamais serei parasita de ninguém.

Sou filho desta cidade que sempre risonha está, por isso orgulhoso eu digo: sou de Belém do Pará!

Páginas Brasileiras III $-33-$

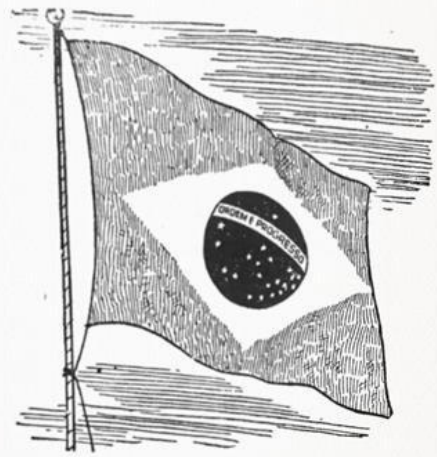

SIMBOLOS DA PÁTRIA

São êstes os nomes dos gloriosos simbolos da nossa Pátria: Bandeira, Hino e Escudo.

Eis os nomes das côres belíssimas de nossa Bandeira: verde, amarelo e azul, havendo ainda a faixa branca, na qual está escrita a legenda: "Ordem e Progresso".

0 verde representa a côr, a bcleza de nossas - florestas, ricas em vegetais.

0 amarelo fala do ouro de nossas minas

$$
-27-
$$

BIBLIOTECA PÚBLICA DQ BARR

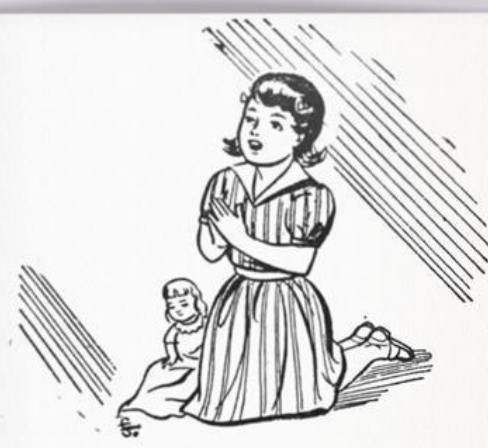

DEUS

Ajoelhemo-nos e oremos.

Quando elevamos assim, ao céu, nosso pensamento, sentimos na alma a confianca absoluta, que sòmente a prece pode oferecer a quem é verdadeiramente cristão.

A fé eleva, reanima e alivia a dor.

Pela fé, vamos ao $\mathrm{Pai}$, pedimos e alcançamos, porque Êle é o amigo de todos os momentos de nossa vida, dando-nos exemplo de humildade e paciência.

Acreditemos em Deus porque Ele existe.

Invoquemo-Lo no silêncio e, juntando nossas mãos, agradeçamos os benefícios recebidos,

$$
-51-
$$

\section{P O E S I A}

O Língua Portuguêsa,

vieste do cruzar de caravelas, florindo o azul do mar,

vieste em luz das páginas mais belas escritas ao luar!

De outros idiomas, nas raizes, surgiste, envolta em luz,

e creio que ficaste brasileira

com a bênção da madeira

com que foi feita a primeira cruz.

Flexāo do substantivo

Dá-se a nexão do substantivo em: gênero (masculino fominino), número (plural e singular) e grau (aumentativo diminutivo).

Fonte: Pesquisa de Campo, Fac-símile da obra da Biblioteca Estadual Gaspar Viana, Belém-Pará. 
Selecionamos alguns textos presentes no Terceiro Livro - Páginas Brasileiras, observando-se diferentes gêneros e a recorrência de Temas. Escritos como elementos textuais direcionados para a leitura, para a escrita e ao conhecimento da língua portuguesa. Os textos presentes neste livro são de autoria de Ester Nunes Bibas. São textos que transportam conteúdos, temáticas, direcionamentos e sentidos, segundo a visão da autora, das políticas educacionais, dos saberes e do pensamento dominante, voltados para a formação escolar.

O livro de Ester Nunes Bibas se reveste de um papel "propedêutico" por prescrever textos em diferentes gêneros. Dos 26 textos apresentados para a leitura, 01 texto normativo de regras para ser bom estudante, 20 textos sob o formato de prosa e 06 poemas associados á literatura religiosa, política, ideológica, regionais, patrióticos, sob a forma de estórias, saudações, valores, condutas recomendadas, natureza, vivências sociais e, identidade paraense e amazônica.

Os textos são seguidos de vocabulários, indicação de conteúdos e exercícios de verificação da aprendizagem. Mesmo que situados no campo da leitura e da escrita, os textos referendam um direcionamento didático-pedagógico a ser seguido pelos professores e alunos do ensino primário no estado do Pará.

Os textos acima destacados serão analisados no V Capítulo deste estudo acadêmico, a partir da perspectiva discursiva dos enunciados trazidos pelos textos impressos neste livro e que dão visibilidade à fala, a escrita e o pensamento educacional da professora normalista Ester Nunes Bibas.

\subsubsection{A Materialidade do Livro "Páginas Brasileiras" - Quinto Livro}

Quadro 4: Descrição Material do Livro "Páginas Brasileiras” - Quinto Ano

\begin{tabular}{|l|l|}
\multicolumn{2}{|c|}{ Despecições } \\
\hline 1. Formato do livro & Traz um formato retangular, com a dimensão de $14,00 \times 20,00 \mathrm{~cm}$. \\
\hline 2. Cores & $\begin{array}{l}\text { Este exemplar por ser uma cópia digitalizada mantém os aspectos da } \\
\text { materialidade uma original do livro. Apresentando a capa deste livro nas cores } \\
\text { cinza, marrom, branco, preto, amarelo e vermelho presentes nas marcas gráficas } \\
\text { nas palavras e desenhos. }\end{array}$ \\
\hline
\end{tabular}




\begin{tabular}{|c|c|}
\hline 3. Paginação & O livro contém 142 páginas \\
\hline $\begin{array}{l}\text { 4. Tipo de } \\
\text { Encadernação }\end{array}$ & O formato do livro aponta para a encadernação do tipo brochura. \\
\hline $\begin{array}{l}\text { 5.Organização } \\
\text { textual, Imagens e } \\
\text { ilustrações; }\end{array}$ & $\begin{array}{l}\text { Os textos são referenciados como "trechos ou parte de trechos escolhidos" de } \\
\text { Autores brasileiros no campo da poesia e prosa. Os textos selecionados não são } \\
\text { Ilustrados } \\
\text { Referencia autores como: Rui Barbosa, Olavo Bilac, Castro Alves, José } \\
\text { Veríssimo. } \\
\text { Humberto de Campos, Menotti Del Picchia, Manuel Bandeira entre outros. } \\
\text { Autores regionais: Catulo da Paixão Cearense, Artur Porto, Cônego Ápio } \\
\text { Campos, Ermelinda Almeida, entre outros. } \\
\text { José Pereira Castro, Thomaz Nunes, De Campos Ribeiro, Estela Maris, Alberto } \\
\text { Ramos. } \\
\text { O livro apresenta } 138 \text { textos selecionados para leitura dos alunos do quinto ano } \\
\text { do ensino primário. }\end{array}$ \\
\hline Autora/Organizadora & Ester Nunes Bibas \\
\hline Editora & $\begin{array}{l}\text { Editora do Brasil S/A } \\
\text { Ano: } 1957 .\end{array}$ \\
\hline
\end{tabular}

Fonte: Estudo material do Quinto Livro - "Páginas Brasileiras".

O livro "Páginas Brasileiras" - Quinto Livro da coletânea didático-pedagógica de autoria de Ester Nunes Bibas apresenta um formato material semelhante ao Terceiro Livro desta coleção, apresentando uma dimensão de 14x20 cm, e uma encadernação do tipo brochura. Este livro é destinado para os alunos do Quinto Ano do ensino primário e apresenta uma proposta diferenciada ao se constituir em uma "SELETA" de textos direcionados a leitura dos alunos. Nesse sentido, não apresenta conteúdos curriculares das diferentes disciplinas referentes ao quinto ano do ensino primário.

Nesta formatação, o livro apresenta 142 páginas, nas quais estão impressos 101 textos selecionados de diferentes autores nacionais e regionais. São escritores que produzem textos e obras a partir de diferentes lugares de inserção como: jornalistas, políticos, educadores, religiosos, literatos, poetas. advogados, médicos entre outros.

Ester Nunes Bibas em sua seleção textual privilegiou autores de grande visibilidade nacional, regional e local, a exemplo de: Rui Barbosa, Olavo Bilac, Castro Alves, José Veríssimo. Humberto de Campos, Menotti Del Picchia, Manuel Bandeira, Catulo da Paixão Cearense, Artur porto, Ápio Campos, Ermelinda de Almeida, Auta de Souza, José Pereira Castro, Thomaz Nunes, De Campos Ribeiro, Estela Maris e Alberto Ramos, entre outros. 
A cópia deste exemplar digitalizado nos possibilitou perceber que somente a primeira capa do livro apresenta-se colorida e com elementos imagéticos, enquanto que as demais páginas apresentam os textos selecionados e sem ilustrações.

É um livro que registra a produção de diversos autores de diferentes tendências literárias. Por serem autores brasileiros e regionais que se situam desde o século XIX e autores do século XX, supomos que nesse processo de seleção textual e organização deste livro, a autora tenha utilizado critérios pessoais, literários, educacionais, políticos ideológicos, por serem escritores que apresentam uma temporalidade de vida bem próxima a da autora e pelo fato de Ester Nunes Bibas ser ao mesmo tempo literata e professora do ensino primário e, na seleção textual do quinto livro de Páginas Brasileiras, estabeleceu uma associação entre literatura e educação, evidenciando vários gêneros literários endereçados a leitura dos alunos do quinto ano primário.

Figura 10 - Primeira Capa, segunda capa e Contra Capa do Livro "Paginas Brasileiras" Quinto Ano Primário.

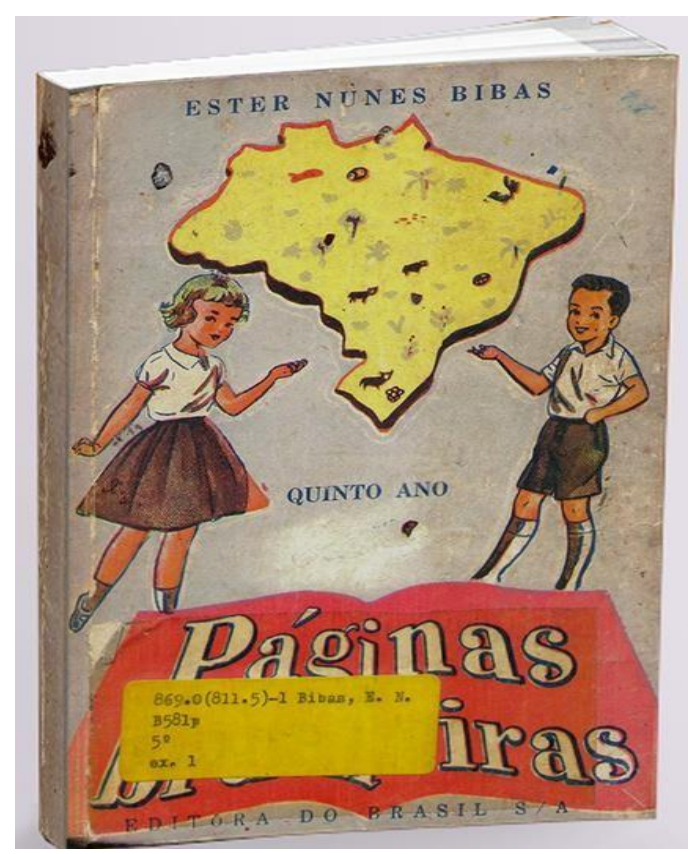

Fonte: Pesquisa de Campo, Fac-símile da obra da Biblioteca Estadual Gaspar Viana, Belém-Pará.

Esta capa como primeira identificação do livro, apresenta-se em uma combinação de cores, que perpassam pelo cinza, amarelo, branco, vermelho e azul marinho, como cores que destacam as ilustrações imagéticas e palavras que atribuem especificidades ao livro Páginas Brasileiras - Quinto Ano e destacam as marcas editoriais impressas que atribuem sentidos e 
significados a essa obra didática. Os tons coloridos presentes possibilitam uma visibilidade melhor da materialidade deste livro com relação à disposição gráfica das imagens, das palavras e a interação entre palavras, imagens e o lugar pensado e impresso.

$\mathrm{Na}$ parte central superior do livro, o registro da autora Ester Nunes Bibas e abaixo desta identificação, um dos destaques desta capa, o mapa do Brasil, na cor amarela e detalhes em marrom-cinza e, vermelho, que tonalizam imagens de animais, plantas, frutos, como imagens representativas do potencial agropecuário do país por regiões nesse momento histórico. Abaixo do mapa, a imagem de uma aluna a direita e de um aluno a esquerda, num gesto corporal que indicam estarem apresentando o Brasil representado pelo mapa geográfico. Os alunos apresentam-se com uniforme escolar. Blusa e camisas brancas com mangas, saia pregueadas para a menina abaixo do joelho e bermuda para o menino em tom azul marinho. Uma imagem que referencia o uniforme da escola pública mantido por décadas como elemento material da cultura escolar brasileira e paraense. Porém, alguns aspectos referentes à identificação dos alunos são muito chamativos. Os alunos apresentam características "étnicas raciais" bem diferenciados das crianças da região. A menina de cor branca, cabelos loiros e o menino com características também distanciadas do padrão paraense.

Uma representação identitárias mais próxima das crianças da classe média do que dos grupos populares paraenses, notadamente "mestiços" e "caboclos" que adentram nas escolas públicas nesse período. Supomos que essa representação deslocada dos sujeitos estudantes esteja relacionada ao discurso educacional reformista de mentalidades e padrões sócioculturais. Nesse sentido, formador de novos sujeitos educados, disciplinados e amantes da nação brasileira.

Na parte central desta capa, a indicação "Quinto Ano", como referência da série para a qual este livro é direcionado. Após esse indicativo, aparece um livro em vermelho e sobre ele, o título "Páginas Brasileiras" em branco, como destaque que nomeia a obra. A dimensão imagética do livro e de sua titulação revela a importância editorial atribuída a esta obra didática; pois, nesse conjunto de informações materiais chama atenção o lugar em que aparece a Editora do Brasil S.A em letra azul de forma discreta na parte final da imagem do livro e consequentemente desta primeira capa.

Uma imagem que direciona o olhar do observador para a centralidade do título "Paginas Brasileiras" - Seleta, como referência a autora da obra e aos escritos de escritores e de escritoras brasileiras de renome nacional e regional. Presenças que asseguram reconhecimento e legitimidade aos gêneros textuais a serem trabalhados pelos alunos da quinta série do ensino primário no estado do Pará. 
Figura 11 - Segunda Capa do Livro "Páginas Brasileiras"

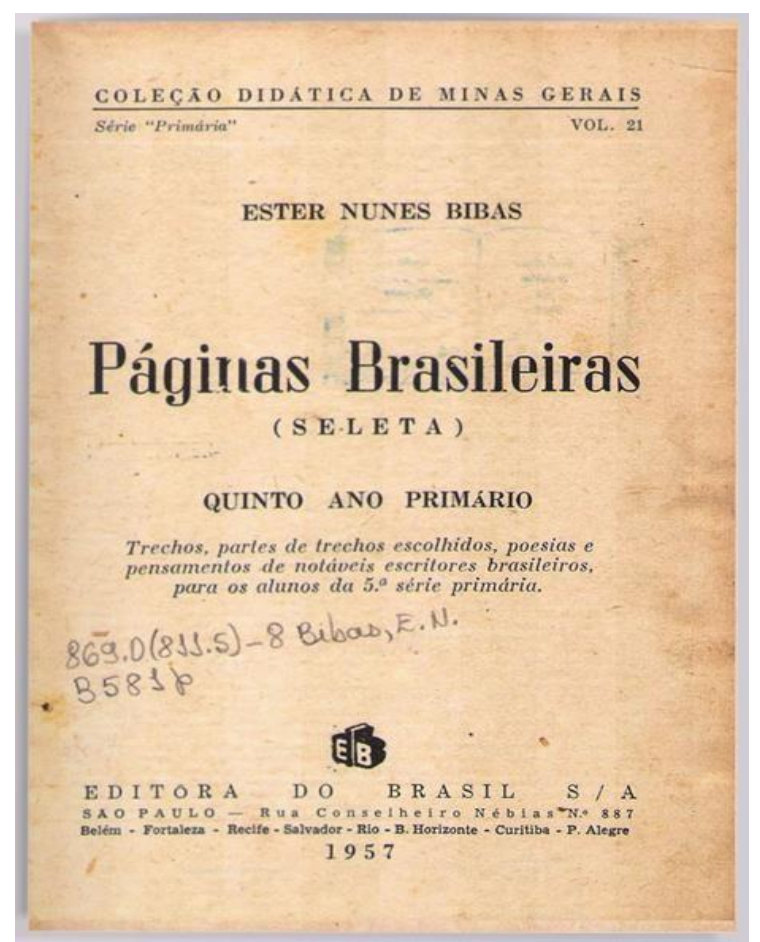

Fonte: Pesquisa de Campo, Fac-símile da obra da Biblioteca Estadual Gaspar Viana, Belém-Pará.

A segunda capa e a contracapa deste livro trazem marcas editoriais importantes que acrescentam dados que reforçam a identidade e a proposição deste livro. Traz registros mais específicos sobre este exemplar. Na margem superior se observa uma importante indicação escrita Coleção Didática de Minas gerais, Série "Primária" Vol. 21. Dado não comprovado pela própria editora do Brasil e demais informações referentes aos livros "Páginas Brasileiras", pela não "guarda" dos livros e registros sobre esta obra, conforme resposta enviada pela editora do Brasil em 28 de abril de 2016.

\section{Editora}

\section{Prezada Ana Maria,}

O livro/coleção mencionado(a) deixou de ser publicado(a) pela editora há algum tempo.

Sendo assim, não possuímos exemplares em nosso estoque. Dependendo da obra, é possível encontrar versão atualizada em nossas filiais/representantes ou em nossa loja virtual www.editoradobrasil.com.br/lojavirtual.

Fonte: Pesquisa de Campo. 
A ausência de registros sobre a obra didática de Ester Nunes Bibas inviabiliza a confirmação a respeito da circulação desta obra na rede escolar de Minas Gerais. Informação não confirmada também pelos familiares entrevistados, o professor Jaime Bibas e a professora Vânia Bibas Rio, netos de Ester Nunes Bibas.

Abaixo deste registro vem nome da autora do livro e o título "Paginas Brasileiras" que aparece mais destacado na parte central da capa e com dados complementares, mas significativos para compreensão deste livro, aparece a palavra (SELETA) que qualifica o livro na sua organização textual, por reunir "Trechos, partes de trechos escolhidos, poesias e pensamentos de notáveis escritores brasileiros, para os alunos da $5^{\text {a }}$ série primária”. Um livro organizado preponderantemente por textos direcionados à leitura, com temáticas focalizadas por seus escritores e escritoras.

Nesta capa, o registro da Editora do Brasil S.A como empresa responsável pela editoração deste livro em 1957, como referência do ano de impressão, sem informações quanto ao número de reimpressões já ocorridas, assim como, o número de livros impressos para o mercado escolar. Considerando que neste ano, Ester Nunes Bibas conta com 69 anos e no ano seguinte aposenta-se das funções de educadora pela compulsória, aos 70 anos. Entretanto, ao compararmos a edição do Terceiro Livro de "Páginas Brasileiras" impresso no ano de 1967, analisado anteriormente, percebemos que pelo menos, por dez anos, as obras desta professora continuaram atendendo os interesses mercadológicos da editora do Brasil S.A e consequentemente circulados no contexto educacional paraense.

Nesta segunda capa, aparece o registro escrito de $\mathrm{n}^{\circ}$ 860.0(811.5)-8 Bibas, E. N B581p como identificação desta obra na Biblioteca Pública do Estado Pará. Fato confirmado pelo registro presente na contracapa que registra a data de chegada deste livro didático nesta biblioteca pública em 12/02/1987, sob o nº 86/87. E um valor mercadológico desta obra de Cr\$27,00. Os registros presentes apontam algumas sinalizações: O livro impresso em 1957 e somente recebido para guarda na Biblioteca Pública do Estado do Pará, após 30 anos dessa edição desse exemplar e quinze anos após o falecimento da autora Ester Nunes Bibas ocorrido em 1972. Na página seguinte referente ao índice deste livro traz a assinatura de Jaime de O. Bibas, neto da escritora. Um dado que emite uma suposição de que esse exemplar esteve até então sob a guarda deste familiar. 
Figura 12 - Índice "Páginas Brasileiras” Quinto Ano.

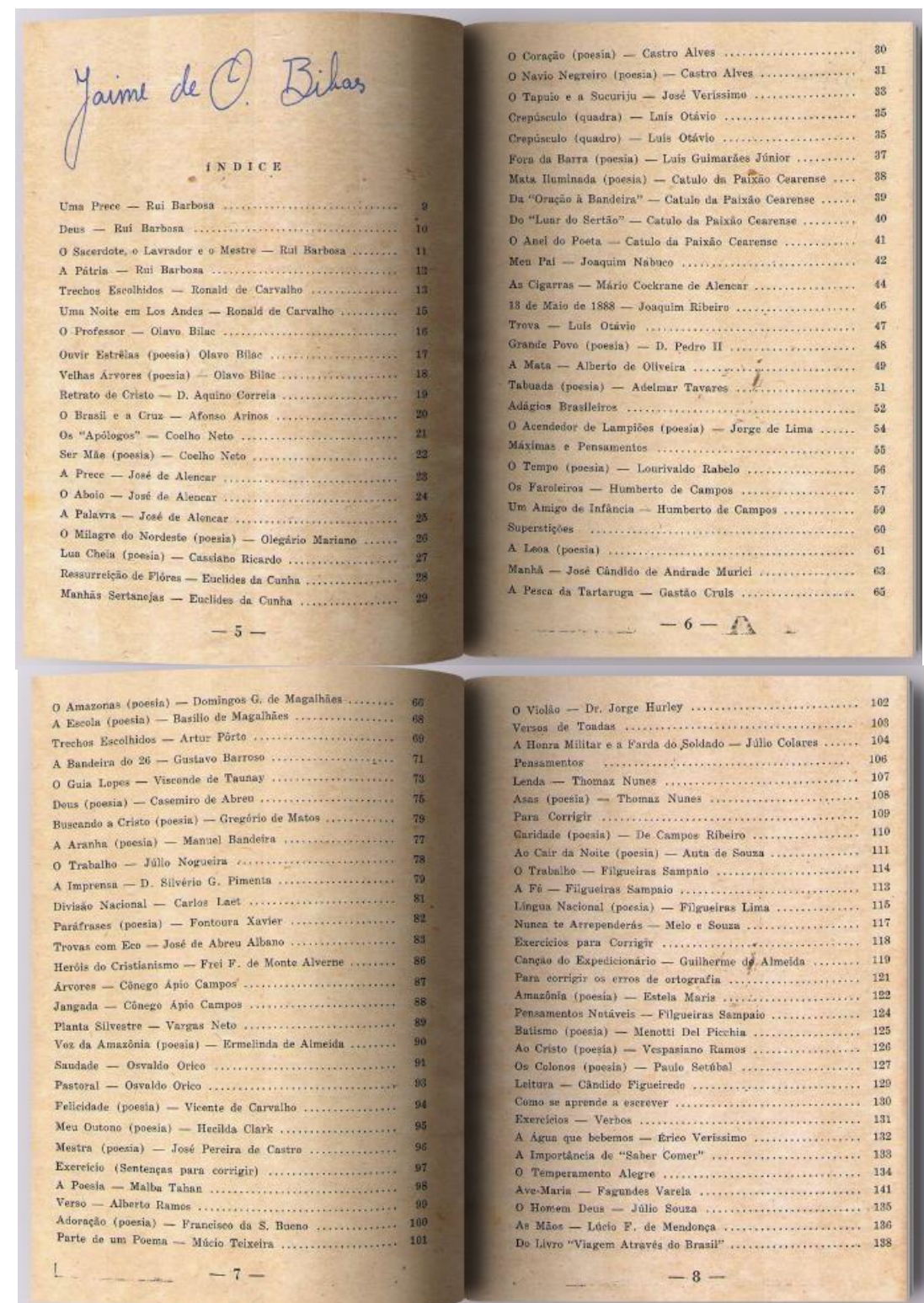

Fonte: Pesquisa de Campo, Fac-símile da obra da Biblioteca Estadual Gaspar Viana, Belém-Pará.

Ester Nunes Bibas em seu Quinto livro da coleção didática "Páginas Brasileiras", seleciona textos, trechos e fragmentos de textos de destacados autores nacionais e regionais do campo da literatura. Em sua maioria, são homens de letras e de diferentes áreas do Saber. Autores que atuam como advogados, jornalistas, médicos, políticos, diplomatas, educadores e religiosos e literatos. Neste livro, a autora desempenha o papel de coordenadora pedagógica, considerando todo o processo seletivo das produções textuais de outros autores.

Nesse processo de escolha, os textos são direcionados à leitura e a escrita dos alunos da quinta série primária. A autora neste exemplar denominado como "SELETA", estabelece uma aproximação entre dois campos em que atua como escritora, a literatura e a educação, 
como caminhos transitados por Ester Nunes Bibas. Nesta intercessão da literatura com a educação, a autora selecionou 138 textos de 72 escritores do campo literário.

Considerando-se a importância dos autores, o processo de leitura e de escrita dos alunos, para os quais são endereçados esta seleta de textos, exigem prontidão e uma apropriação da língua Portuguesa, por tratar-se de escritos por homens cultos, referenciados então pelas normas da língua e da linguagem.

Os textos literários se materializam por diferentes gêneros textuais: prosa, poema, estórias, pensamentos, orações. Que desempenham um papel de disseminar temas e conteúdos direcionados a formação dos professores e dos alunos, encaminhados por diferentes tipos campos de veiculação. Sendo bem identificada a literatura religiosa, moral e cívica, e literaturas com ênfase a cultura e a cotidianidade regional. E nesse processo formador, as abordagens e pensamentos trazidos pelos autores selecionados, se revestem de autoridade para imprimir condutas e condicionamentos para a formação escolar e identitários dos estudantes neste momento.

Quadro 5: Vinculações políticas, educacionais, filosóficas e Literárias dos autores.

\begin{tabular}{|l|l|l|}
\hline $\begin{array}{l}\text { APORTES EPISTEMICOS/ } \\
\text { PENSAMENTO }\end{array}$ & $\begin{array}{l}\text { LUTORES } \\
(\mathbf{7 0})\end{array}$ & $\begin{array}{l}\text { LUAR } \\
\text { Republicanos / nacionalistas Políticos, jornalistas, escritores e de } \\
\text { textos e obras educativas: autores nacionais de grande } \\
\text { referência. }\end{array}$ \\
$\begin{array}{l}\text { POSITIVISTAS/ } \\
\text { REPUBLICANOS. }\end{array}$ & $\begin{array}{l}-10 \\
\text { autores: }\end{array}$ & \begin{tabular}{l}
$\mid$ \\
\hline
\end{tabular}
\end{tabular}

\begin{tabular}{|c|c|c|}
\hline $\begin{array}{l}\text { HUMANISTAS (PENSAMENTO } \\
\text { LIBERAL CRISTÃO) }\end{array}$ & -10 autores & Homens religiosos ou Escritores católicos \\
\hline Literatos & $\begin{array}{l}\text { Romantismo: } 07 \\
\text { Parnasianos: } 03 \\
\text { Modernistas: } 08 \\
\text { Barroco: } \quad 01\end{array}$ & $\begin{array}{l}\text { Grandes autores nacionais reconhecidos como } \\
\text { romancistas, poetas, cronistas. }\end{array}$ \\
\hline Educadores & $\begin{array}{l}03 \text { autores } \\
\text { - } \text { herança intelectual do } \\
\text { Positivismo. } \\
\text { - Pensamento educacional } \\
\text { higienista. } \\
\text { - } \quad \text { Educação republicana. }\end{array}$ & $\begin{array}{l}\text { Escritores, homens de letras, Professores a } \\
\text { exemplo de José Veríssimo. }\end{array}$ \\
\hline Regionalistas & $\begin{array}{l}\text { - } \quad 04 \text { escritoras } \\
\text { - } \quad 07 \text { escritores }\end{array}$ & Escritores e escritoras amazônicos e nordestinos. \\
\hline Filólogo/ didáticos & -03 & $\begin{array}{l}\text { Autores no campo da Linguagem e professores- } \\
\text { escritores. }\end{array}$ \\
\hline Aurores sem referência & - 12 autores & \\
\hline
\end{tabular}


A construção desse quadro a respeito das identificações e vinculações políticas, educacionais, filosóficas e literárias dos autores partícipes da Seleta de Ester Nunes Bibas, proporcionou a compreensão desses autores, a partir do lugar que falam e escrevem seus textos. Em sua maioria são homens letrados, nos quais, Ester Nunes Bibas vai buscar orientações, fundamentações que subsidiam a sua escrita no campo literário e no campo da educação.

A partir da pesquisa biográfica desses autores identificou-se que grande a maioria desses escritores são contemporâneos à trajetória de Ester Nunes Bibas, que transitam do século XIX para o século XX. Um dos autores se localiza no decorrer do século XIX, e alguns desses autores, a partir do início do século XX.

Independente do lugar que falam ou escrevem, são em sua maioria homens de "letras" e, assim se circunscreverem no campo literário como romancistas, contistas, cronistas, poetas ente outros gêneros textuais, são produtores de obras ou textos, a partir de suas vinculações política, educativa, religiosa e suas associações à correntes de pensamento, matrizes epistêmicas e ou ideológicas, que substanciam a palavra escrita, que ganha materialidade pela prosa, pelo poema, pelo conto, pela crônica, pelas estórias, pela oração e narrativas sobre o contexto regional.

Escritores e uma representação de 04 escritoras, como sujeitos historicamente situados, e que deixam fluir em seus escritos suas visões de mundo, de sociedade, de educação e a respeito do processo de formação escolar por diferentes caminhos de inserção. Autores vinculados ao pensamento positivista e republicano, que impõe à educação, o papel reformador da sociedade e dos indivíduos diante das exigências da modernidade da sociedade e do fortalecimento Estado Republicano.

No campo literário, diferentes autores se localizam como românticos, parnasianos, modernistas, barroco, regionalistas. No âmbito da educação, autores que se perfilam na defesa de uma educação atrelada ao positivismo, à educação republicana e a educação higienista.

Neste rol de escritores, identificam-se autores preocupados com a questão da linguagem e da linguística. São autores do campo da filologia e que trazem para o campo da educação, a preocupação com a origem e a formação das palavras. Autores que produzem dicionários da língua Portuguesa e normatizações sore a palavra escrita.

Uma identificação interessante que reforça o reconhecimento dos autores selecionados e de que a maioria desses escritores são homens pertencentes à Academia Brasileira de Letras e ou as Academias de Letras de seus estados de origem ou até de outros estados. Um dado que reconhece o potencial intelectual e do valor de seus escritos para o campo das letras e para 
outros campos, como a educação, que tem buscado a ampliação dos processos de leitura pelo estudo de textos literários.

Ester Nunes Bibas dá vazão à voz e aos escritos de escritores e escritoras regionais. Autores localizados de forma mais local e, expressam em seus escritos, os aspectos geográficos, ambientais e culturais do Nordeste e da região amazônica. Por se situarem fora centro intelectual brasileiro, o que justifica autores e autoras sem maiores identificações, ou sem nenhuma referencia.

Figura 13 - Gêneros textuais - Páginas Brasileiras - Quinto Ano.
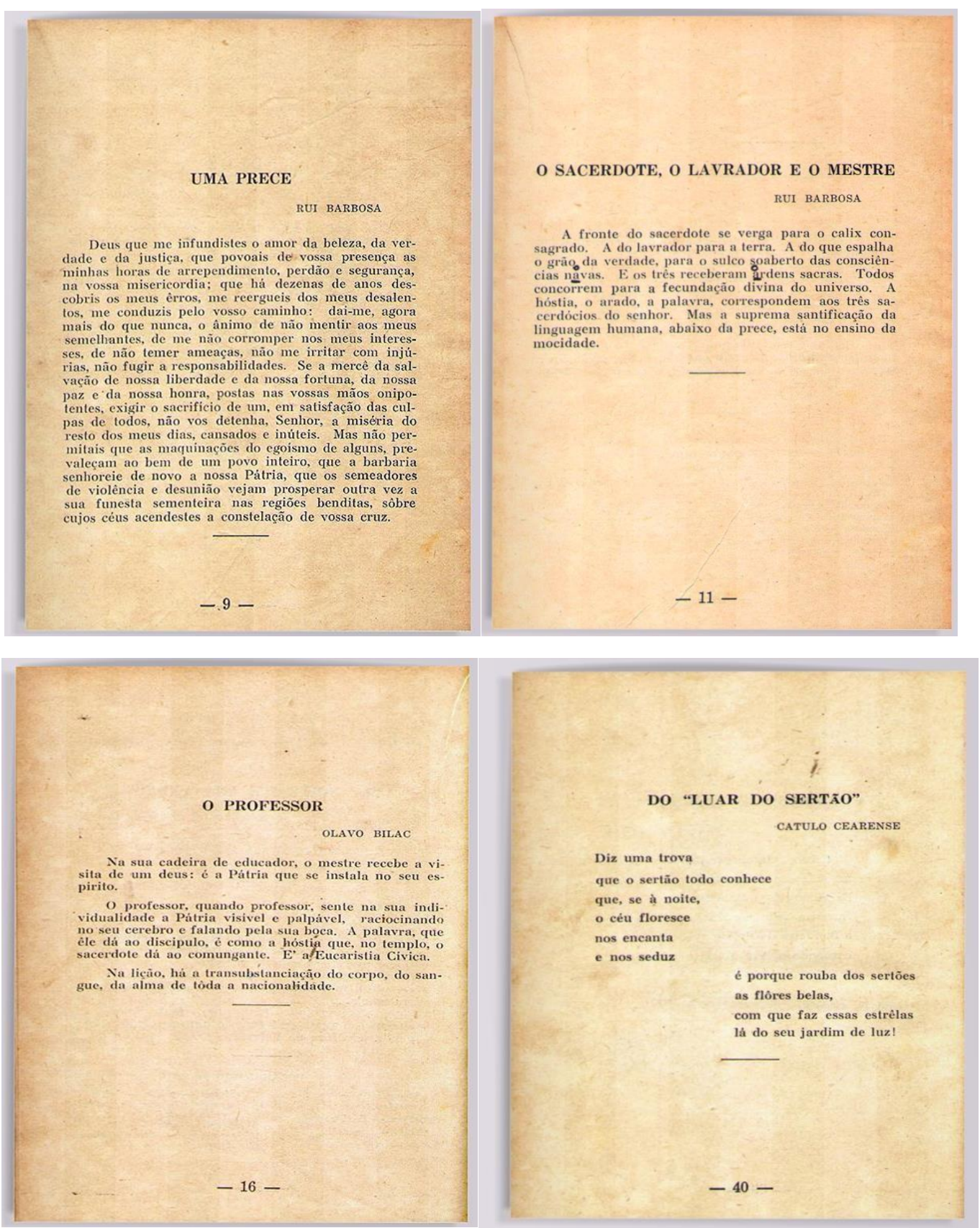

Fonte: Pesquisa de Campo, Fac-símile da obra da Biblioteca Estadual Gaspar Viana, Belém-Pará. 


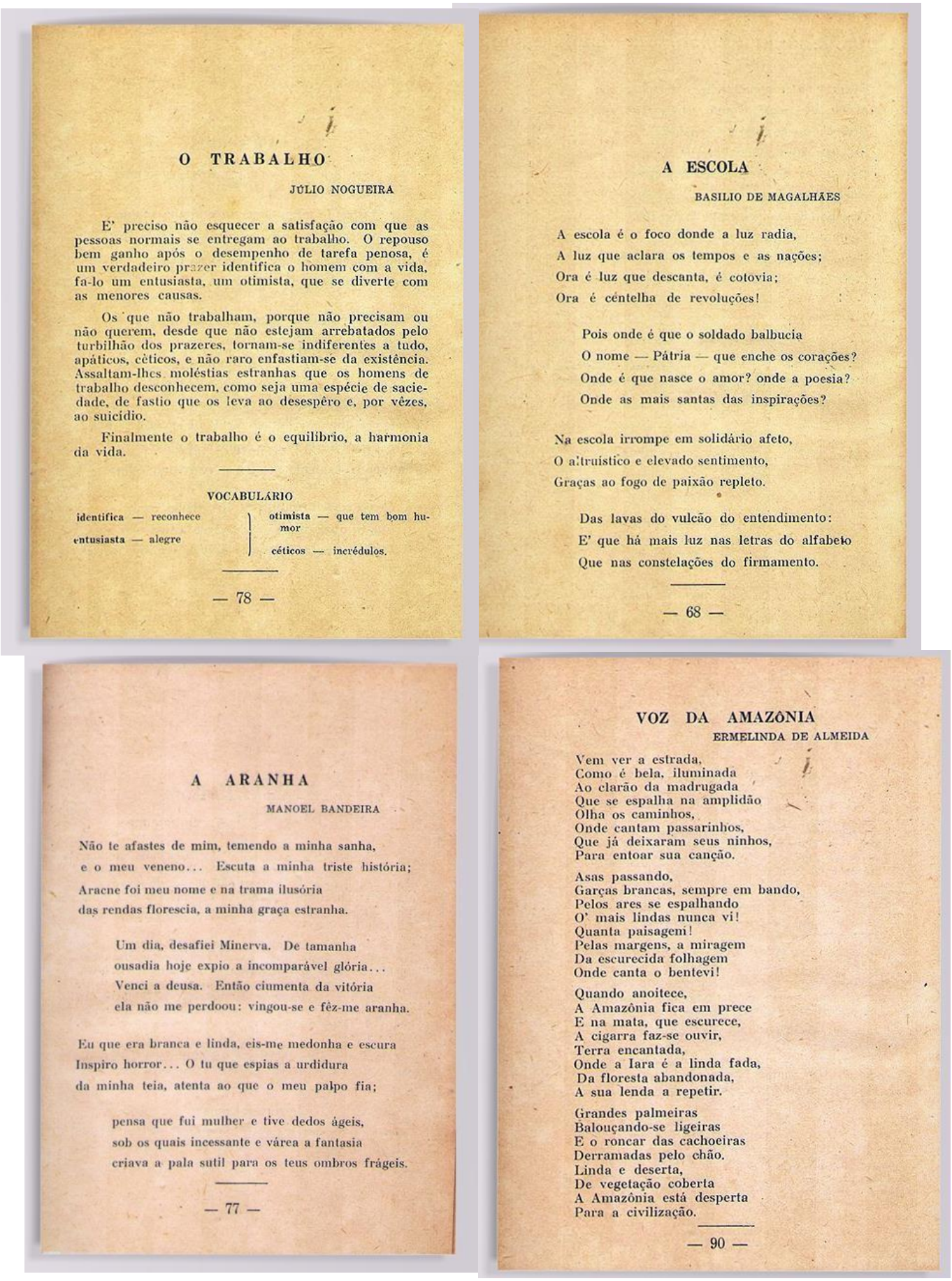

Fonte: Pesquisa de Campo, Fac-símile da obra da Biblioteca Estadual Gaspar Viana, Belém-Pará. 

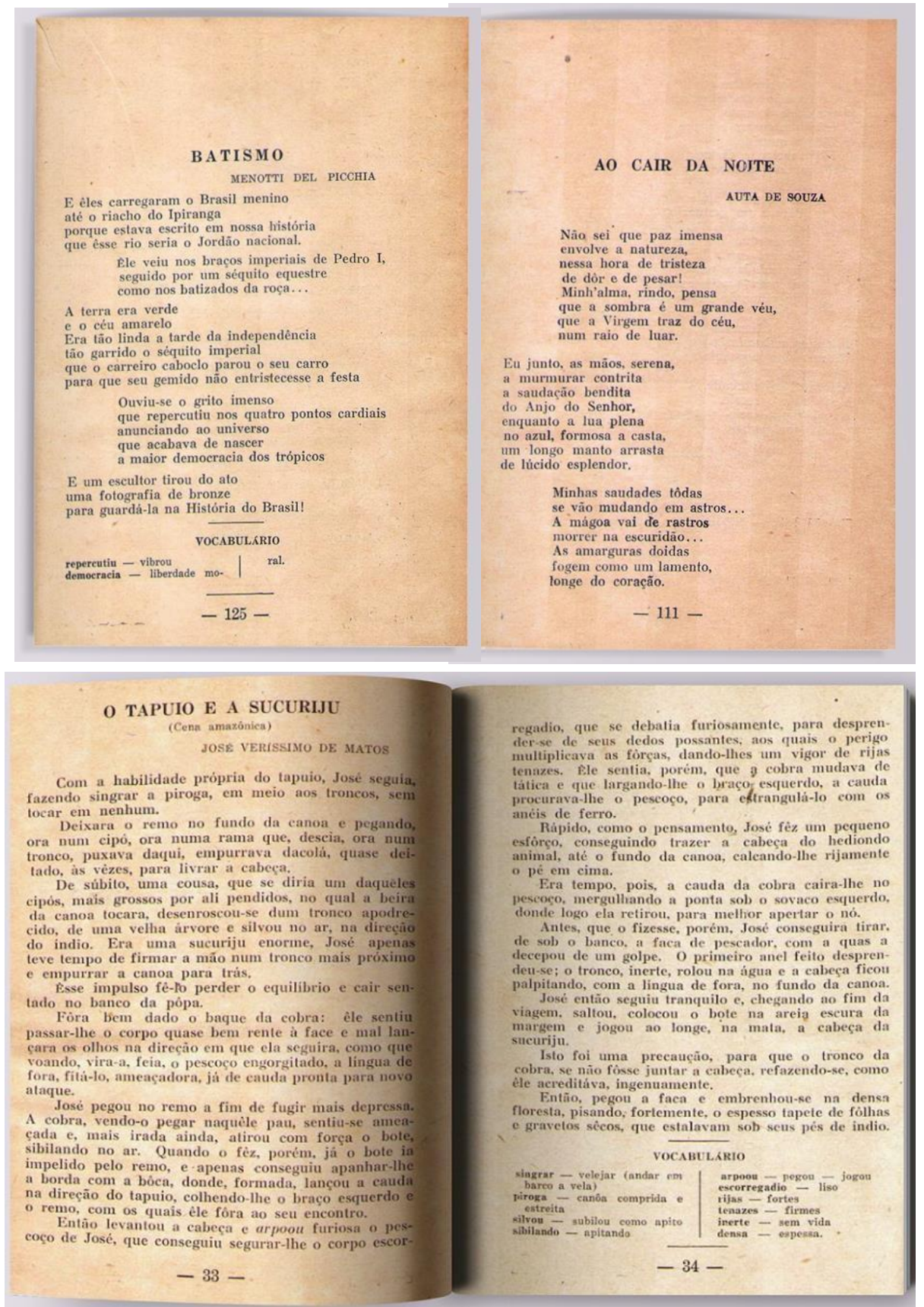

Fonte: Pesquisa de Campo, Fac-símile da obra da Biblioteca Estadual Gaspar Viana, Belém-Pará.

Os gêneros textuais escolhidos para a leitura dos alunos do quinto ano do ensino primário na verdade apontam para uma formação escolar mais ampliada para esses alunos, considerando-se que os textos literários são revestidos de perspectivas, de visões de mundo, de concepções de educação, de escola, do papel do professor e nesse olhar focado para o campo escolar, se insere o processo de leitura como experiências a serem vivenciadas na sala de aula, que apontam para o "ler" para aprender e o aprender para uma leitura mais ampliada a medida em que, definem um lugar para a educação, para o professor, para o aluno e os sentidos da escolarização. 
A autora de "Páginas Brasileiras" neste processo formador e apropriação de habilidades ampliadas para a leitura estabelece uma relação imbricada entre literatura e educação, em particular pela seleção de textos literários, ou trechos desses, utilizados para essa intencionalidade pedagógica.

Pela leitura desses textos literários, observa-se que são textos escritos num tempo e com um propósito. Nesse sentido, transportam para o campo da escolarização seu potencial formativo, e tornam-se porta voz de discursos políticos, estéticos, poéticos e educacionais. Pensados, escritos e direcionados para serem lidos por um público em processo de formação escolar.

Nesta formação escolar, a leitura e a escrita da língua, assume um lugar de importância na escolarização de crianças e adolescentes. Processo que passa a ser intercambiado pela utilização didática dos textos literários. Ainda que utilizados de forma fragmentada por trechos ou fragmentos literários endereçados a leitura. No entanto, essa associação da literatura e os processos de escolarização “determina os textos a serem lidos e os conhecimentos que devam ser extraídos, cabendo ao professor mostrar a importância da leitura, a sua serventia e o que é possível conhecer através dela” (SANTOS, 2008, p. 16).

O reconhecimento do valor dos textos literários transformou esse gênero textual, em veículo expressivo de poder. Pelo seu encaminhamento a um público ainda em formação, a fala, a escrita, as percepções do autor em relação à visão de mundo, de sociedade, de educação e da formação escolar afeta esse público leitor. O texto literário emana sentidos e apreensões do sujeito que fala e escreve pela linguagem literária, esta "propõe extrapolações semânticas e sintáxicas e até caminhos diferenciados para a compreensão da realidade cotidiana através de seu caráter mimético, polissêmico e ambíguo com forte riqueza conotativa" (Idem).

Santos (2008), nessa aproximação da literatura e da educação, percebe que os textos literários estabelecem interseções com outros campos de conhecimento, os quais são desenvolvidos e instruídos com base no discurso pedagógico moderno e seus interdiscursos, que pretendem dar a voz à ciência, à cultura e a sociedade.

Percebemos a partir da materialidade deste livro, o lugar privilegiado da leitura e sua mediação por textos literários. Como se trata de um livro direcionado para a quinta série primária e considerando-se neste momento da escolarização uma apropriação do ler e do escrever, os textos trabalhados se direcionavam então para a promoção e desenvolvimento intelectual dos alunos em formação escolar, considerando-se que os alunos da escola pública concluíam apenas esse nível de ensino. Assim, o propósito da leitura se voltava para o 
conhecimento da língua portuguesa, transverso pelo contexto histórico-ideológico que direcionava o olhar e a apreensão de valores dominantes como elementos precípuos para a construção do sujeito leitor.

Os textos literários são utilizados pelos livros didáticos, em especial os livros didáticos "Páginas Brasileiras", como estratégia didática que valoriza gêneros literários e ao mesmo tempo assumem um papel privilegiado para a formação escolar com relação à leitura e a escrita; pois nesse processo formador se inserem as camadas populares com suas características, seus ritmos, ritos e linguagem própria. No entanto, as práticas escolares mediadas pela linguagem literária "propõe extrapolações semânticas e sintáxicas e abre caminhos diferenciados para a compreensão da realidade cotidiana através de seu caráter mimético, polissêmico e ambíguo com forte riqueza conotativa" (SANTOS, 2014, p. 16).

Um contexto formativo de confronto de visões de mundos, considerando-se tempos históricos e lugares distanciados presentes nos textos e trechos literários direcionados à leitura. Assumem neste livro didático, como discursos estéticos, artísticos, político e educacional no processo formação de leitores.

Ester Nunes Bibas traz em seus livros Páginas Brasileiras produções textuais que revelam ou se aproximam da realidade contextual dos alunos. O aspecto regional, principalmente belenense e paraense é destacado nos textos para leitura, com maior incidência no Terceiro Livro, aspecto também presente no Quinto Livro. Como aspectos transversais que permeiam o estudo da linguagem, ilustrações e narrativas que valorizam a identidade amazônica e a identidade nacional pelo processo de construção de um ideário de nação.

Os livros regionais presentes no país se revestem de uma produção cultural que destacam seus autores, editores e o contexto sociocultural local, para o qual se destinam. Um aspecto importante presente nos livros Páginas Brasileiras, através de textos sobre a região amazônica, a realidade belenense e paraense; considerando-se que se tratando do Estado do Pará, os livros didáticos desse período eram provenientes de autores de outras regiões do país e desta forma a presentavam abordagens distanciadas da realidade regional.

Seguindo essa apreensão, os textos selecionados no Terceiro e no Quinto livro de Páginas Brasileiras, registrados nesse capítulo, subsidiarão os estudos da obra Páginas Brasileiras de autoria de Ester Nunes Bibas pela perspectiva da Análise discursiva dos textos desta autora e textos de escritores selecionados, na perspectiva bakhitiniana e aproximações aos estudos de Orlandi (2015); Fiorin (2015); Sobral (2009); Chartier (2014); Burke (2010) e Perrot (2007).

Intencionamos neste processo de análise discursiva, a compreensão do lugar, de onde 
Ester Nunes Bibas fala e escreve e, apreender as concepções e as matizes epistêmicas que atravessam o pensamento educacional desta professora paraense com relação à concepção de educação, o papel da escola, dos professores, do aluno e da formação escolar. Estudo e análise que serão desenvolvidos no capítulo sexto, integrante desta tese. 


\section{O PENSAMENTO EDUCACIONAL DE ESTER NUNES BIBAS: DISCURSOS E INTERDISCURSOS}

O presente capítulo retrata o processo investigativo pautado em procedimentos teórico-metodológicos para a efetividade do estudo, da análise e da compreensão do pensamento educacional da professora Ester Nunes Bibas; focalizando-se nesse processo o apreender e o compreender desse pensamento em suas associações epistêmicas e históricoideológicas que blindam o pensamento e a obra didática de Ester Nunes Bibas enquanto proposições didático-pedagógicas para o ensino primário no estado do Pará. Neste processo, o capítulo em tela intenciona analisar os discursos e interdiscursos perceptíveis na produção textual presente no livro didático "Páginas Brasileiras" de autoria desta professora normalista.

Para dar conta deste processo de análise, esse capítulo se constitui em lócus investigativo centrado nos discursos e interdiscursos da autora e sua obra didática. Considerando-se em primeira instância, que a tese versa sobre a escrita e o pensamento intelectual feminino para o campo da educação, especialmente, trazendo como proposição a construção biográfica intelectual de uma professora normalista, sob a focalização do olhar: da mulher, professora e escritora de livros didáticos. Numa segunda instância, a focalização da história e da produção intelectual de uma mulher paraense, a professora Ester Nunes Bibas, como sujeito-objeto desta produção acadêmica no âmbito da educação. Temática que no âmbito da investigação acadêmica que vem ganhando interesse em Programas de PósGraduação em vários estados brasileiros, destacando-se o Maranhão, Bahia, Rio Grande do Norte, Paraná, Santa Catarina entre outros; Estudos conformados pela condição de invisibilidade e silenciamento de professoras-escritora de obras didáticas. A presente tese se constitui a primeira iniciativa acadêmica no Estado do Pará, que traz a mulher, professora normalista, escritora de livros didáticos, enquanto produção local-regional para o campo da educação e como já enunciado sob a conformação desse olhar investigativo se depara com as condicionantes da invisibilidade e o silenciamento desta autora paraense pela ausência de registros históricos oficiais, $\mathrm{O}$ que torna o caminho investigativo entre rastros, memórias de familiares, e documentos fragmentados. Diante desse condicionante, a tese em tela e de sobremaneira o capitulo atual, subsidia-se na perspectiva histórico-cultural como referencial teórico-metodológico e pelas contribuições de autores de diferentes vertentes que atravessam o campo da História Cultural para dar conta da história dessa mulher, enquanto intelectual do campo da educação do Pará e nessa trajetória como sujeito esquecido pela história, seja como, mulher, professora e escritora, mulher que tem sua fala, seus escritos e seu pensamento 
intelectual impresso. No contexto desse sujeito mulher paraense "subalterna", "periférica" recorremos às contribuições de Roger Chartier (1992, 1997, 2002, 2009), José Barros (2007, 2009), François Dosse (2004), Peter Burcke (1997, 2002, 2007), Jean François; No campo da Mulher: Michelle Perrot (2007), Del Priore (1997), Scott (1998), Spvak (2010), Alambert (2004); Do campo da história intelectual, nos aportamos em Jean François Sirinelli (2003). Edward Said (2011) e Bakhtin $(1997,2009)$ e autores do Círculo, trabalhados no capítulo teórico-metodológico como suporte aos o estudo, as análises e apreensões sobre o sujeito Ester Nunes Bibas, seu pensamento, suas proposições e sua obra, como caminhos para compreender o lugar desempenhado por Ester Nunes Binas no cenário paraense/regional e suas interligações com as proposições da educação brasileira.

\subsection{O LÓCUS ENUNCIATIVO DA PESQUISA}

Considerando-se a intencionalidade desta tese em apreender e analisar o pensamento educacional de Ester Nunes Bibas, o estudo do livro didático "Páginas Brasileiras" e da intelectualidade de sua autora, pautou-se na análise dos enunciados evocados nesta obra didática, diretamente relacionados aos discursos pedagógicos presentes nos textos endereçados à leitura e a escrita escolar. Neste sentido, os enunciados e o contexto discursivo presente neste livro didático ganhou centralidade neste capítulo, entendendo-se que o lócus enunciativo neste cenário investigativo:

[...] trata do lugar discursivo em que o analista lança seu olhar sob a perspectiva das relações estabelecidas entre os sujeitos e os discursos, considerando-se seus processos de identificações na ordem dos discursos (SILVA, 2006, p. 27,28, apud SANTOS, 2004, p. 112).

Nessa apreensão, o presente capítulo mira-se no campo da linguagem, especialmente no estudo do discurso pedagógico de uma professora normalista e escritora do campo da educação e traz como objetivo principal o apreender e o compreender do pensamento, da escrita e das proposições pedagógicas desta autora sob o olhar do feminino. Entretanto, esse processo de análise dá continuidade aos estudos sobre o livro didático "Páginas Brasileiras" iniciados no capítulo anterior, em que se desenvolveu a análise desta obra didática, a partir dos aspectos materiais, organizacionais e editorias que possibilitaram ler indícios e marcas que dão visibilidade aos propósitos pedagógicos do livro em questão. Salientando-se que o capitulo em tela é direcionado pelo olhar investigativo centralizado nos aspectos discursivos, 
demarcadores da fala e dos escritos desta autora paraense.

Dito isso, o estudo focaliza o pensamento educacional de Ester Nunes Bibas e a partir do recorte metodológico da Análise do Discurso subsidiada pelos estudos bakhtinianos e autores do Círculo. Todo processo de análise e interpretação se norteará pelas concepções e orientações interpretativas oriundas desta vertente de análise de discurso. Assim sendo, o estudo proposto se fundamenta na concepção de língua, linguagem, enunciados, sujeitos enunciadores, interlocutores, produção de sentidos à palavra, ao texto escrito como discursos histórico-ideológicos de um tempo-lugar, veiculados pela obra didática de autoria de Ester Nunes Bibas.

A fala discursiva desta autora inscreve-se numa ambiência do social e do histórico em suas possibilidades de produção de sentidos, os quais tonalizam o pensamento intelectual desta escritora. Uma fala que emerge do e no contexto histórico-ideológico da sociedade e da educação paraense entre as décadas de 1950-1960, período de produção, impressão e circulação da coletânea "Páginas Brasileiras", composta por cinco livros didáticos para o ensino primário.

Sob a perspectiva bakhtiniana, o presente estudo se encaminha para uma apreensão da escrita intelectual desta autora, como resultante da ação dialética e dialógica, em que os discursos revelam a atuação de um sujeito enunciador, que dirige seu projeto enunciativo à interlocutores, dos quais, espera um agir como resposta para a efetivação de seus propósitos pedagógicos. Compreendendo-se que a constituição desse discurso pedagógico se dá pela relação imbricada com o discurso ideológico imerso no contexto teórico e nas práticas didático-pedagógico, veiculadores ideológicos nos processos formativos e educacionais.

Pautando-se nas observações de Geraldi (2013), a respeito de que Bakhtin originariamente "nada escreveu sobre a educação", centralizando seus estudos no campo da literatura, no entanto, entre os textos bakhtiniano, o "romance de formação" abre possibilidades de extrair ensinamentos que servem não só para compreender a emergência do gênero, mas as preocupações sinalizadas com a formação humana, questão central dos processos educativos formais ou informais. Embora Geraldi (2013), reconheça que o texto mencionado não remeta às questões diretas do campo educacional, reconhece também, o que Bakhtin escreveu, disse também aos educadores, a partir de suas reflexões a respeito do princípio da alteridade fundante na constituição do eu e do outro em processo de interatividade verbal, que constitui a "completude provisória" dos sujeitos, por renovar-se neste processo de interação, em que a linguagem assume lugar simbólico de sentidos, significações, mobilizadores da participação ativa dos sujeitos, que se movimentam em meio 
um contexto cultural localizado por intermédio da fala, dos saberes enunciados, de forma ética e responsável pelo que diz como ato que caracteriza o seu agir. Assim, situando o estudo deste capítulo no contexto formativo e enunciativo da educação num contexto localizado, o estado do Pará; o estudo de Análise Dialógica do discurso, mediante as observações apontadas por Geraldi (2013), como caminho investigativo que possibilita o extrair e o deslocar os conceitos indicativos da base arquitetônica e filosófica desta perspectiva para o estudo e análise de discurso da obra didática "Páginas Brasileiras", de autoria de Ester Nunes Bibas.

A escolha pelo campo da linguagem e do discurso, especialmente pelos fundamentos da Análise Dialógica do Discurso está vinculada às possibilidades de estudo acerca da apreensão dos enunciados em sua concretude, que subscrevem ações de sujeitos ativos, inseridos num dado contexto social, político-ideológico. Enunciados carregados de sentidos para o campo da educação escolar, e diante de enunciados concretos produzidos por sujeitos concretos localizados numa realidade social. Uma contextualização dada a ler, ainda que de forma transversal nos ditos, nos escritos e nos subtendidos presentes na obra, objeto desta análise, como aspectos importantes para a sinalização da materialidade discursiva. Nesse entendimento, a Análise do Discurso, tornou-se caminho investigativo para a compreensão do pensamento educacional da professora Ester Nunes Bibas. Focaliza-se nesse processo analítico a produção textual desta autora e textos selecionados de autores brasileiros, enquanto textos mediadores da leitura e consequente da aprendizagem da língua materna. Textos em seus sentidos direcionados para a formação escolar e constituição identitária do sujeito estudante.

Uma obra didática produzida e circulada num tempo e lugar determinado, direcionada aos sujeitos envoltos no processo de formação escolar primária. Se constituindo uma produção didática histórico-cultural localizada historicamente e, que no presente encontra-se ocultada e silenciada pelo tempo de produção e pela ausência de registros sobre a obra e sua autora. Um condicionamento histórico que aponta para um estudo analítico centrado na linguagem e em especial nos termos discursivos didático-pedagógicos.

Estudo, então pautado na abordagem de análise trazido por Bakhtin e autores do Círculo, a partir de uma visão de linguagem em sua dimensão dialógica, atravessada pelo contexto social, histórico-ideológico, e notadamente marcada pela atuação participativa dos sujeitos envoltos num dado processo de comunicação; processo mediado pela leitura e escrita, veiculadores da aprendizagem da língua materna. Considerando-se nessa abordagem os protocolos enunciados para a formação escolar, expressos por via da linguagem escrita, constitutiva dos discursos pedagógicos, pautados nos aspectos significativos da história, da 
cultura, da educação e da ideológica de um tempo-lugar, sinalizados por este livro didático; assim como, os aspectos ou dimensões que significam a visão de mundo, o lugar social dos sujeitos em interação e de suas condições vivenciais. Como componentes extralinguísticos que atribuem direcionamento ao pensamento, a fala e os posicionamentos assumidos e ou a eles associados.

Neste processo de análise além das contribuições de Bakhtin e autores do Círculo, nos pautaremos nos estudos de autores brasileiros estudiosos do campo da linguagem, do discurso, como Orlandi (2005, 2012); Brait (2013, 2014); Sobral (2009); Fiorin (2015); Chartier (2002); Perrot (2006, 2007) para aproximação e compreensão deste campo investigativo e suporte para a construção de um dispositivo de análise que contemple a análise textual, os processos enunciativos, os discursos, seus sentidos e significados impressos na produção didática de Ester Nunes Bibas. Consideramos como suportes teóricometodológicos importantes para o processo de apreensão, interpretação e compreensão do pensamento educacional de Ester Nunes Bibas, como mulher, professora e escritora, e suas imbricações com o contexto social, histórico e ideológico, que matizam a fala, os escritos e suas interdições com outros discursos. Como também, reveladores do papel da educação, da escola, da prática pedagógica dos professores com vistas aos processos de escolarização.

Outro aspecto importante buscado nesta análise se refere ao apreender do lugar social do qual, Ester Nunes Bibas materializa sua fala impressa na coletânea didático-pedagógica "Páginas Brasileiras", e deste lugar, o estudo e análise sobre "o que diz Ester Nunes Bibas e, como diz seus discursos", não como linguagem isolada, ou monológica, mas a partir da concepção dialógica que centra sua análise na interação verbal entre sujeitos de um mesmo contexto sociocultural, constituídos como enunciadores num dado momento histórico. Constituindo-se como falante e ouvinte que estabelecem relações de interatividades em alguma dimensão desse processo de comunicação oportunizada pela relação do ensinoaprendizagem, e especialmente pelos estudos desses gêneros textuais pela via da leitura e escrita.

\subsection{BAKHTIN E O CAMPO DA LINGUAGEM}

Bakhtin (2009) é reconhecido como um dos principais filósofos e pensadores russo do século XX do campo da literatura, linguagem e do discurso. Como estudioso organiza um círculo de amigos intelectuais, que passou a ser conhecido como "Círculo de Bakhtin". Os intelectuais de diferentes campos do saber que produziram obras mediatizadas pela questão da 
linguagem. Para Brait (2015), o Círculo de Bakhtin, era formado por intelectuais russos de diferentes tendências oriundas da história, da Filosofia, da Literatura, da linguística, da Biologia, do Magistério, da arte, da Música entre outras áreas de conhecimentos e que por cinquenta anos apresentaram uma efetiva produção relacionada ás questões centrais do pensamento bakhtiniano. Nesse processo de produção, Brait, esclarece que:

\footnotetext{
O pensamento e os escritos passaram a ser reconhecidos como produto de trabalhos de vários autores, aí incluídos Mikhail Bakhtin (1895-1975); Matvei Isaevich Kagan (1889-1937); Pavel Nikolaevich Medvedev ( 1891- 1938); Lev VasilievichPumpianskii ( 1891-1940); Ivan Ivanovich Sallertinskii (1902-1944); ValetinNukolaevichVoloshinov (1895-1936) e outros (BRAIT, 2015, p. 79-80).
}

Autores que num trabalho contínuo tornaram-se partícipes da construção de uma concepção filosófica e metodológica de análise da linguagem, compreendida como Análise Dialógica do Discurso. E para compreender tal proposição, torna-se necessário apreender o contexto histórico em que se dá a construção do pensamento bakhtiniano.

A construção desta Filosofia Materialista da Linguagem emerge no cenário pósrevolucionário da Rússia socialista e esse olhar trazido pela perspectiva bakhtiniana assume um posicionamento crítico, a partir da análise, questionamento e contraposição ao formalismo dominante no campo da linguagem e da literatura russa. Até então, notadamente marcada pelo objetivismo abstrato do campo da linguagem e da linguística e do subjetivismo idealista. $\mathrm{O}$ que segundo a perspectiva bakhtiniana, não davam conta da linguagem para além de signos estáveis, vistos então como sistema estrutural e de normatividade para a língua. Para a perspectiva dialógica, a palavra, o texto ao transformarem-se em veículo enunciador de discursos ganham fluidez e estabilidade pelas condições contextuais específicas de um dado tempo e lugar que situam os sujeitos falantes. Uma preocupação que vai gerar avanços para a Teoria Geral da Literatura, da Cultura e da Teoria da Estética da criação verbal. O que apontava para a centralidade da compreensão do homem, da ideologia, e da consciência do lugar social desses sujeitos enunciadores de discursos inscritos no contexto da linguagem. $\mathrm{O}$ que remete a inspiração filosófica de tradição marxista pela centralidade da constituição e da atuação humana. Demarcada por uma concepção filosófica da linguagem que se amplia pela busca de subsídios no campo da crítica literária, na História, na Linguística, na Arte, na Antropologia e na Psicologia; como campos subsidiares para a apreensão e compreensão do sujeito, seus discursos localizados num tempo-lugar determinado. 
Bakhtin (2009) e autores do Círculo evocam em suas obras uma abordagem filosófica da linguagem substanciada pela materialidade dialética do mundo social, então apreendido e compreendido pelo campo da linguagem. Nesse campo, a palavra oral ou escrita, é vista como elemento fundamental nos processos comunicacionais, como veículo promotor de interatividade verbal entre sujeitos. A linguagem é concebida como atividade humana permeada por sentidos e significados atribuídos pelos sujeitos enunciadores. A palavra e as produções textuais se constituem de conteúdos denotativos a partir da valoração e da apreciação evocadas pelo agir humano, mediante posições e ações ativas, participativas de sujeitos em suas vivências. Assim, o dizer e o dito transparecem a realidade concreta da linguagem em sua dimensão social.

Sobral (2008) reforça o papel ideológico da palavra dita ou escrita, por apresentar-se circunscrita a um cenário histórico-ideológica e nos enunciados proferidos num dado evento de interação verbal em que o "locutor e o interlocutor" apresentam o "mesmo peso", uma vez que cada enunciado é uma resposta, uma réplica à enunciações anteriores e Posteriores. O que explicita em Bakhtin (2009), o caráter dialógico da linguagem de forma contínua devido seus atrelamentos ao já dito, e a possibilidade ao dizer no futuro, ainda de forma renovada. E assim afirma Bakhtin:

Todo enunciado pressupões um ato enunciativo, assumindo um lugar determinante na produção verbal, em que enunciar refere-se ao ato de dizer, como dizer e a quem dizer, em decorrência da potencialidade provocadora da linguagem. Enquanto o enunciado refere-se ao resultante, o produto do ato de enunciar, referendado pelo já dito e propulsor de novos dizeres, por encenar um cenário de muitas vozes e sentidos produzidos num dado contexto e que poderão ser renovados em outros contextos e em outra temporalidade.

Os estudos do Círculo problematizam e confrontam o pensamento corrente dominante em relação ao campo da linguagem e ao campo político ideológico num momento histórico de afirmação do poder e da força política revolucionária russa. Posições que levaram Bakhtin ao exílio e uma ferrenha perseguição política que tornaram seus escritos e obras sem reconhecimentos e proibidas de serem publicadas e assim, vetado o direito á circularidade do pensamento de Bakhtin e autores do Círculo. Escritos, que somente serão reconhecidos na década de 1960 e no Brasil tornaram-se conhecidas nas décadas seguintes pelo esforço de escritores brasileiros como Faraco (2013); Fiorin (2015); Brait (2015); Sobral (2009); entre outros estudiosos que passaram a traduzir as obras desse pensador e a produzir livros que facilitaram a compreensão da perspectiva de Análise do Discurso. 
A proposição de uma filosofia materialista da linguagem encontra-se nas obras Marxismo e Filosofia da Linguagem de autoria de Bakhtin/Voloschinov (1929) e Estética de Criação Verbal (Bakhtin, 1992), que reúne textos escritos por Bakhtin, ainda que inacabados por conta do adoecimento deste autor. Textos que estruturam a proposição de Análise Dialógica do Discurso e apontam uma concepção de linguagem, como ato produzido pelas relações interativas entre sujeitos historicamente situados. O campo da linguagem como espaço dialógico de construções de saberes, de constituições de sujeitos, que são produzidos pelas relações entre o "eu", o "tú" e os outros imersos numa cotidianidade sociocultural, marcada por uma formação histórico-ideológica, que tende a cimentar e pinçar a materialidade da vida do dia a dia dos sujeitos envolvidos num evento de comunicação.

O contexto polifônico é evidenciado nesta proposição por atribuir o tom às concepções de mundo, de homem, de cultura, de história e de uma representação de uma realidade concreta e de sujeitos concretos, que carregam seus discursos e seus posicionamentos a respeito desses ideários nos atos de enunciações discursivas. Nesse evento social e histórico, a linguagem e o discurso, se transformam em meio estratégico no desvelar da vida cotidiana em seus múltiplos aspectos da realidade social, cultural, política, ideológica, dimensões da vida em sociedade em suas especificidades de tempo e lugar, que revelam os sujeitos numa encenação interativa; ainda que marcada por tensões e conflitos trazidos pelo lugar social de enunciação.

Considerando-se que o ato de enunciar pressupõe uma atuação e um agir como:

[...] produto da interação de dois indivíduos socialmente organizados e mesmo que não tenha um interlocutor real este pode ser substituído pelo representante médio do grupo social ao qual pertence o locutor. A palavra dirige-se a um interlocutor, ela é função da pessoa desse interlocutor, não pode haver interlocutor abstrato (BAKHTIN/VOLOSHINOV, 1979, p. 98).

Os estudos pautados na Análise dialógica do discurso se efetivam a partir de situações enunciadas da vida cotidiana e ainda esses estudos priorizem os discursos literários, estes devem partir das representações evocadas e expressas pelo autor, pelos personagens e ou de outros campos, os quais devem possibilitar a compreensão do agir dos sujeitos e do seu mundo material, produzidos nas relações dialógicas, ou seja, pelas ações mediadas nos processos de interação verbal. Neste processo, os sujeitos envolvidos são apreendidos em seu agir, como ato ético e responsável diante de situações vivenciadas e partilhadas no mundo social, ao qual pertence, como realidade concreta. No campo da linguagem e do discurso, a intervenção dos sujeitos podem impetrar mudanças na materialidade social, nos aspectos 
simbólicos de significações e dessa formar alterar as representações da realidade social, que podem ser apreendidas, suscitadas e ou contrapostas, seja pelo pensar, pelo comparar e pelo agir.

Segundo Sobral (2009), a vida de cada sujeito é construída por uma sucessão de atos concretos e complementa, o sujeito age numa situação concreta, organizada em torno de práticas sociais, considerando que essas práticas "supõem" outros sujeitos em suas situações concretas.

Supõem situações concretas e sujeitos concretos, supõem ainda a intencionalidade de sujeitos a realizar atos e sua realização concreta de acordo com formas aceitas de realização, ainda que sempre em realização individual relacional (SOBRAL, 2009, p. 29).

Nessa concepção dialógica, ainda que imaginário ou pretenso, o ouvinte, o leitor e ou interlocutor, é um sujeito concreto e historicamente situado, assim como o enunciador, são sujeitos com direito a voz. O processo de linguagem é polifônico, pois diferentes vozes atravessam a fala e o escrito: sujeitos e discursos são constituídos pelo "eu" e pelo(s) "outro" (s). O locutor e/ou o enunciador não é o único sujeito na cena de enunciação, pois para garantir recepção e alcance, seu discurso necessita ser dividido com o outro, na proporção que, o ato enunciativo orienta, planeja e justifica o discurso enunciado sempre direcionado a seu interlocutor. Dessa forma, a concepção dialógica bakhtiniana inscrita no campo da linguagem e em eventos de comunicação verbal, Esta concepção materializa-se num contexto dialógico e dialético, com interferência na constituição intersubjetiva do "eu" e do "outro" num movimento interacional de troca, de completude e ou de contraposição entre os sujeitos envolvidos.

Segundo Bakhtin (2009), ainda que diante de discursos autoritários que destacam o enunciador, tendem a silenciar o(s) interlocutor(es) e caracterizados a princípio como discurso monológico, são contrapostos pela dimensão polifônica do discurso dialógico, trazido por Bakhtin (2009); ao asseverar que a enunciação monológica fechada constitui, de fato uma abstração ao considerar que: 
Toda enunciação monológica, inclusive uma inscrição num monumento constitui um elemento inalienável da comunicação verbal. Toda enunciação, mesmo de forma imobilizada da escrita, é uma resposta a alguma coisa e é construída como tal [...] Não passa de um elo da cadeia dos atos da fala (BAKHTIN/VOLOCHINOV, 2009, p. 101).

Nessa perspectiva, a interação verbal se faz presente ainda que não seja enunciada uma única palavra pelo interlocutor e torna-se uma enunciação plena e concreta a partir do processo de apreensão e compreensão dos sentidos verbais e não verbais relacionados presentes no discurso oral ou escrito. Sendo assim, pela emergência da compreensão via apreensão da disposição da linguagem interna e externa, a enunciação se concretiza pelo discurso interno. Como dimensões e formas determinadas pelo contexto da enunciação. “ A cada palavra da enunciação que estamos em processo de compreender, fazemos corresponder uma série de palavras nossas, formando uma réplica".( BAKHTIN/VOLOCHINOV, 2009, p. 137).

O tom enunciativo marcado por uma "sonoridade" marcada pela discursividade provoca no interlocutor, uma "recepção ativa" e uma resposta diante do discurso de "outrem", mediante uma apreensão apreciativa, o que demostra uma compreensão ativa dos componentes enunciativos a ele direcionado; que passam a ser filtrados pelo discurso interior, absorvidos ou não por sua consciência, tornando "aquele que apreende a enunciação de outrem não é um ser mudo, privado de palavras, mas ao contrário um ser cheio de palavras interiores" (BAKHTIN/VOLOCHINOV, 2009, p. 153,154).

$\mathrm{Na}$ enunciação apreciativa, a palavra assume um sentido conotativo e se submete as influências dos sistemas ideológicos vigentes. A ideologia do cotidiano torna-se dominante no contexto imediato da enunciação, presente na palavra interior e exterior, como parte de um sistema ideológico norteador da moral social, fundamentada pelo campo da "ciência, da arte e da religião", como campos normatizadores dos saberes e da vida social e dessa forma, cristalizada no contexto da vida cotidiana dos sujeitos em interlocução. Assim, “de um lado, a ideologia dominante e, do outro, a ideologia do cotidiano, expressas nos acontecimentos da vida do dia-a-dia”. Mas com igual poder, agem nos processos de apreensões e compreensões dos sujeitos em interação.

O escritor Adail Sobral (2009), salienta que o agir não está relacionado a um ato físico, natural, mas ao ser revestido de ato ético e responsável, tornam-se enunciados simbólicos, valorativos que lhe atribuem um lugar discursivo e provocativo que encenam possibilidades de respostas do interlocutor. 
Uma apreensão apreciativa produtora da potencialidade de se tornar ser falante; o que implica a adoção de atitude responsível diante dos enunciados alheios. Segundo Bakhtin/Volochinov (1992, [1979]), a compreensão ativa que suscita a simultaneidade de uma compreensão responsível ativa do que foi ouvido, e que poderá desencadear um ato, um comportamento acatado por esse processo de compreensão. O que torna segundo o interlocutor numa posição e locutor e de enunciador.

Constituindo-se nesse cenário de enunciações, os sujeitos da linguagem, enquanto sujeitos identitários, que falam e escrevem a partir de posições sociais nem sempre igualitárias. No entanto, somente se constituem numa relação intimamente relacionada com a alteridade. Concepção que rompe com existência monológica do eu, no sentido de que necessitamos do outro para me constituir e reconhecer como eu; ao conferir prestígio e reconhecimento do outro. Uma percepção de concepção de sujeitos que se coloca como oposição ao apagamento do outro.

A dimensão dialógica proposta por Bakhtin assegurada pela interatividade verbal reverbera inevitavelmente para a compreensão de sujeito ativo e participativo. O Sujeito então, construído da confluência da individualidade subjetiva em suas relações sociais com outros sujeitos, como condicionamentos que o constitui. Em Volochínov (1976a), “o sujeito é pensado em termos de interação constitutiva com a sociedade. Em outras palavras, toda relação entre ao menos duas pessoais já é um evento social, uma relação social e histórica”. (VOLOCHINOV, 1976, apud SOBRAL, 2009, p. 47).

Para Sobral (2009), a relação interpessoal é marcada pelos recortes históricos ideológicos, num dado tempo-lugar, que confere o lugar e o papel dos sujeitos historicamente localizados. Nesse contexto, os sujeitos em seus múltiplos papéis e interações em diferentes grupos sociais, se inserem no domínio da construção ideológica do psiquismo e ao domínio da participação do psiquismo na construção ideológica da realidade em que vive. Os sujeitos sofrem as interferências do aparato ideológico e agem de forma interferente na constituição ideológica da sociedade, na qual estão inseridos.

Nesta concepção, o agir do sujeito não é neutro e sua atuação é revestida de responsabilidade, o que lhe atribui um papel de agente atuante e assim, responsável pelo agir sobre o diz e sobre o que faz em sociedade, embora, seja considerado, a proporcionalidade do ato em decorrência do lugar social, do qual fala.

A palavra imersa no contexto simbólico da enunciação, assume um lugar valorativo e torna-se campo privilegiado no processo de construção e materialização do fenômeno ideológico. A palavra é considerada o veículo que melhor representa o mundo social, por 
expressar a construção e sua concretude, mediante as sinalizações trazidas pelos encontros e interações de sujeitos. Cada signo vai se enchendo do domínio ideológico e assim, tornandose parte inerente dos processos de comunicação por via da expressão verbal.

A palavra constitui-se um signo ideológico por excelência, como modo mais puro e sensível (e) preenche qualquer espécie de função ideológica, em decorrência dos sentidos a serem alcançados num determinado campo ou esfera de ação como o estético, o científico, o moral, o religioso entre outras esferas de atividade humana.

A palavra escrita assume um destacado lugar na emissão de juízo, de valor e nessa função apreciativa, a fala textual é materializada pelos gêneros discursivos, considerando os formatos incorporados, o que leva os gêneros discursivos assumirem diferentes tipologias por se adequar ao projeto discursivo do sujeito enunciador.

Para Bakhtin (2003), a atuação do enunciador se dá pela escolha certa de gêneros discursivos, que enfatizam sua intenção discursiva. Todo enunciador fala através de determinados gêneros do discurso. O que significa dizer que, que todos os enunciados se revestem de formatos relativamente estáveis. Assumem um lugar de visibilidade estética ao enunciado e leva-se em consideração a esfera ou campo em que se dá o ato enunciativo e serão diversos quanto à diversidade da atuação humana. Cada campo ou esfera apresenta suas especificidades, como o literário, o histórico, o pedagógico, o jurídico, o científico, o religioso entre outros campos de atuação dos sujeitos.

Nesse contexto enunciador, o discurso reveste-se de tipologias utilizados pelos sujeitos como formas estéticas que dão feição e expressividade aos enunciados proferidos. No campo da enunciação, os gêneros discursivos enfatizam os aspectos destacados nos diálogos, como mediadores nos processos de produção estética da linguagem. São tipos e formas que revestem e dão materialidade aos discursos, por isso assumem diferentes tipologias para se adequar ao projeto discursivo do sujeito enunciador e dá atendimentos aos sentidos que o enunciador quer dizer e como dizer, considerando-se também a receptividade e o agir como resposta do ou dos interlocutores, como sujeitos para quem é direcionado o discurso.

O texto em suas multiplicidades de gêneros e temas denotam a intencionalidade do autor, então, dirigida a alguém, o leitor, o estudante. Assim, o que o autor diz e como diz estabelece um "ir e vir", entre autor/leitor, impregnado de sentidos e significados. Considerando-se que a autora fala de seu lugar, da sua posição social, cultural e ideológica. $\mathrm{O}$ que interfere na estrutura composicional de seu texto, por ser marcado pela lógica de pensamentos e ideias, a partir das marcas da cultura letrada.

Bakhtin realiza estudos tendo como referência os gêneros literários, campo em que sua 
análise contempla uma variedade de gêneros dos discursos e a partir do momento em que suas obras ganham circularidade, seus estudos passaram a ser incorporados por outros campos do conhecimento em defesa da natureza dialógica da linguagem, como resultante dessas contribuições para o processo de análise do discurso em diferentes esferas em que a fala, o escrito exercem função discursiva.

Pela divulgação e aprofundamento do pensamento do Círculo de Bakhtin, a vertente dialógica do discurso tornou-se vertente analítica reconhecida a partir das últimas décadas do século XX. As universidades públicas brasileiras encamparam as orientações desta perspectiva teórico-metodológica nos processos de análise discursiva; o que vem proporcionando uma contínua produção acadêmica de teses, dissertações, artigos, temas e debates evidenciados em seminários, congressos e na produção de livros. Uma produção acadêmica a partir dos estudos do Círculo de Bakhtin, inicialmente recepcionado pelo campo das letras e da linguística, mas se estendendo pelo campo da história, geografia, e outros campos das Ciências Humanas, entre as quais, o campo da educação, do ensino-aprendizagem e nos estudos de livros didáticos, sob o olhar da formação de sujeitos, em que a palavra, o livro didático e ou as práticas pedagógicas, assumem um lugar de importância, como elementos estratégicos para o ensino-aprendizagem com visibilidade para a relação social entre sujeitos para além da exclusividade da compreensão do conhecimento escolar, mas enquanto sujeitos com direito a voz, ao pensar e atuar de forma ativa, interativa, como sujeito da linguagem.

\subsection{ANÁLISE DISCURSIVA DOS GÊNEROS TEXTUAIS NO LIVRO DIDÁTICO "PÁGINAS BRASILEIRAS"}

A análise do livro didático "Páginas Brasileiras" se efetiva sob o recorte analítico dos gêneros textuais produzidos ou selecionados pela autora Ester Nunes Bibas. Textos que se revestem de discursos pedagógicos, veiculadores de saberes para o campo escolar, como saberes matizados por pensamentos e valores, encaminhados como propósitos didáticopedagógicos á educação paraense, propósitos sinalizados por sentidos a serem alcançados junto aos sujeitos estudantes e de instrumentalidade para as práticas pedagógicas, ao referenciar orientações "propedêuticas" do ensinar, do apreender e o que aprender no processo formativo e constitutivo de sujeitos que acessam a escola pública neste momento histórico.

Neste processo de análise discursiva estabelecemos interconexões com alguns campos investigativos que perpassam pelo estudo do livro didático enquanto gênero de discurso, pelo 
campo da linguagem, da linguística e da literatura, ao centralizar a análise de gêneros textuais endereçados à leitura e a educação de crianças e jovens do ensino primário. Nesta esfera de análise do discurso, o livro didático em seus diferentes gêneros, apresenta-se como:

[...] ato de fala impresso, constitui igualmente um elemento da comunicação verbal.
Ele é objeto de discussões ativas sob a forma de diálogo e, além disso, é feito para
ser apreendido de maneira ativa, para ser estudado a fundo, comentado e criticado no
quadro do discurso interior, sem contar as reações impressas, institucionalizadas,
que se encontram nas diferentes esferas da comunicação verbal escritas, resenhas,
que exercem influência sobre os trabalhos posteriores, etc.). Além disso, o ato da
fala sob a forma de livro é sempre orientado em função das intervenções anteriores
na mesma esfera de atividade, tanto as do próprio autor como as de outros autores:
ele decorre, portanto da situação particular de um problema científico ou de um
estilo de produção literária. Assim, o discurso escrito é de certa maneira parte
integrante de uma discussão ideológica em grande escala: ele responde a alguma
coisa, refuta, confirma, antecipa as respostas e objeções potenciais, procura apoio,
etc. (BAKHTIN/VOLOCHÍNOV, 2009, p.127-128).

A formação escolar é matizada por reflexões, princípios normativos de condutas e de ações responsivas do aluno diante das práticas sociais, das atividades escolares, que norteiam e sistematizam a formação educacional. Um campo que envolve a atuação de diferentes sujeitos, engajados e direcionados para o ensino-aprendizagem. Uma esfera de atividade formativa, para a qual, o livro didático se tornou meio estratégico para a dinamização do saber escolar e das práticas didático-pedagógicas. Se tornando veículo, que refrata e ao mesmo tempo é refratado pelo pensamento educacional, pelas políticas de Estado, pelos valores culturais e ideológicos dominantes. E assim, revestindo-se de seu papel histórico e revelador do contexto educacional, societário e dos sujeitos envoltos no campo educacional.

Segundo Adail Sobral (2009), os enunciados discursivos adentram numa corrente interacional de sujeitos por imprimirem orientações, visões de mundo. No campo da educação, os textos pedagógicos mediam o ensino-aprendizagem, numa esfera em atuam sujeitos produtores de saber escolar.

Neste campo, os livros didáticos apresentam-se em seus múltiplos papeis, como objeto cultural e como instrumento social e pedagógico formador de crianças e jovens para além da formação escolar, pois, seu papel no letramento escolar perpassada pela leitura e escrita emanam contextos, valores morais circulados nas falas, nos pensamentos e nos direcionamentos que interagem de forma direta nos processos de formação constituinte dos sujeitos, mediante a adoção de respostas de condutas e práticas socialmente aceitas ou esperadas pelo contexto histórico-ideológico, pela reprodução e ou reconstituição dos padrões culturais, indicativos da ordenação da vida em sociedade. 
Os textos didáticos nessa perspectiva são atravessados por reflexões, princípios normativos de conduta do sujeito estudante e do sujeito cidadão. Neste campo, os enunciados didático-pedagógicos encarnam uma funcionalidade de nortear e sistematizar a educação escolar. Textos, que, a princípio apresentam-se autorizados Transparecendo desta forma veículos do pensamento corrente por suas associações interdiscursivas. A obra didática "Páginas Brasileiras" é produzida e circulada em um contexto local/regional, compreendida como uma produção didática periférica e escrita por uma professora normalista, inserida num contexto sociocultural, em que a mulher, professora e escritora se deparam com as amarras da ocultação e do silenciamento. Contexto esse de invisibilidade do feminino que possibilita nesse processo investigativo, descortinar um leque de indagações a respeito do lugar social do qual enuncia seu pensamento educacional expresso em suas proposições didáticopedagógicas. Sua coletânea didática para o ensino primário lhe assegura o reconhecimento de uma mulher intelectual do e no campo da educação, num período em que o letramento das camadas populares tornara-se urgente e emergencial, diante das demandas do contexto de modernidade tardia vivenciado pelo país nas décadas 1950-1960.

Dito isso, iniciou-se o processo de análise de textos, considerando-se a recorrência temática e apresentarem indícios que descortinam o pensamento educacional de Ester Nunes Bibas.

A análise dos gêneros textuais se pautou nas seguintes observações:

- Se tratando de livros didáticos ( $3^{\circ}$ e $5^{\circ}$ livros $)$ componentes da coletânea primária "Páginas Brasileiras", que referenciam conteúdos disciplinares deste nível de ensino: língua portuguesa, matemática, história, geografia, ciências, optamos pela análise discursiva de textos indicados para a leitura e para a aprendizagem da língua Portuguesa. Entre esses, produções textuais de Ester Nunes Bibas e textos de outros autores referendados pela autora.

- No campo do letramento escolar, os gêneros textuais assumem importância relevante, como unidade discursiva atravessada pela história e pela interferência ideológica, que impõem sentido e significado a fala do autor e direcionada a interlocutor (es) real ou pretenso. Traz o propósito do alcance do Outro e ou de Outros sujeitos. Esta obra didática local se direciona aos alunos e professores do ensino primário do estado do Pará.

- Os Textos escritos enunciados transformam-se em discursos ao imprimir direcionamentos, normatividades e sentidos que atuam na interação autor-leitor, sujeitos de um contexto histórico localizado, ou seja, sujeitos de um tempo e de um lugar de uma mesma comunidade social, histórica e cultural, ainda que desempenhem papeis e lugares diferenciados, neste contexto de letramento, pelo viés da leitura e da escrita centramos o olhar 
na citação de Adilson Citelli, ao prefaciar o livro de Roseli Figaro (2015), que sinaliza para atentarmos para a "força que os discursos verbais continuam a desempenhar: reconhecer a sua presença, significado e abrangência”, como observações importantes e reveladoras para a compreensão do dito, do escrito e dos aspectos subliminar do texto. O texto como unidade discursiva da linguagem, enquanto ferramenta social que imprime sentido ao sistema estrutural da língua e estabelece uma estreita relação entre autor/leitor e demais interlocutores.

Quadro 6: Textos Selecionados para Análise.

\begin{tabular}{|c|c|}
\hline Terceiro Livro - Páginas Brasileiras & Quinto Livro - Páginas Brasileiras \\
\hline 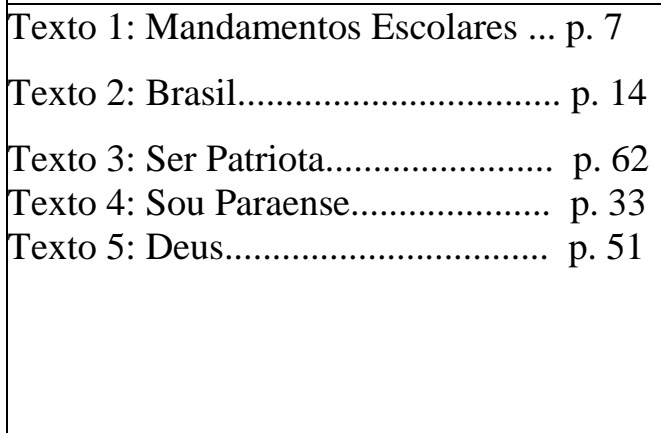 & $\begin{array}{l}\text { Texto 1: O Professor - Olavo Bilac.............p. } 16 \\
\text { Texto 2: O sacerdote, O Lavrador, e o Mestre. } \\
\text { Rui Barbosa................................. p. } 11 \\
\text { Texto 3: A Pátria - Rui Barbosa...............p. } 12 \\
\text { Texto 4: O trabalho - Júlio Nogueira...........p. } 78 \\
\text { Texto 5: Voz da Amazônia } \\
\text { Ermelinda de Almeida.....................p. } 90\end{array}$ \\
\hline
\end{tabular}

Fonte: produção da autora com vistas ao processo de análise.

A partir das considerações mencionadas, propomos uma análise interdisciplinar na observância de indicativos teóricos, conceitos e procedimentos metodológicos. Em especial a vertente da Análise Dialógica do Discurso sob a perspectiva Bakhtiniana, que contemple análise textual, processos enunciativos, gêneros discursos e seus sentidos impressos na produção didática de Ester Nunes Bibas, que tendem a revelar o pensamento educacional e suas imbricações com o contexto social, histórico e ideológico que matizam a fala e os escritos e suas interdições com outros discursos direcionados para ao papel educação, da escola e para a prática pedagógica dos professores com vistas aos processos de escolarização. Assim como, apreender o lugar social do qual Ester Nunes Bibas materializa sua fala, ao produzir uma coletânea didático-pedagógica "Páginas Brasileiras". E deste lugar apreender o que Ester Nunes Bibas diz? Como diz? E seu direcionamento a sujeitos de um mesmo contexto sociocultural enunciadores num dado momento histórico, falante e ouvinte que estabelecem relações, enquanto sujeitos em interação verbal. 


\subsubsection{Apreensões Discursivas dos Gêneros Textuais em "Páginas Brasileiras" - Terceiro} Livro

Os gêneros textuais na perspectiva de enunciados discursivos são entendidos como objetos linguísticos, sem perder sua dimensão de concretude material, situados historicamente. Sua materialidade somente é compreendida pela sinalização dos sentidos e, tornando-se então, como objeto linguístico, material, concreto e histórico, além de seus elementos pronunciados de significados simbólicos. O que lhe remete um poder para encaminhar uma interpretação para além do que afirma o texto em sua literalidade.

O processo de análise textual e de apreensão discursiva se pauta no reconhecimento do poder e da autoridade da palavra escrita, seja esta palavra, segundo Chartier (2014), "afirmada ou contestada", mobiliza significados, por inserir aspectos que imprimem sentidos a essa produção. Aspectos que se apresentam como pano de fundo sobre o qual e inscrevem os motivos que justificam a direção do olhar para o processo de análise.

\footnotetext{
Articulação e a compreensão do significado do texto entre restrições, transgressões e liberdades refreadas. As formas materiais da palavra escrita ou das competências culturais de leitores marcarão sempre os limites de compreensão (CHARTIER, 2014, p. 42).
}

Os gêneros textuais trazidos pelos livros "Páginas Brasileiras" se voltam para a área da educação primária. São textos de autoria de Ester Nunes Bibas e de autores selecionados pela autora. Enquanto textos pedagógicos dirigidos à aprendizagem da língua, da leitura e da escrita. Nessa esfera, os textos apontam direcionamentos para as práticas pedagógicas, ao focalizar sua intervenção na formação e atuação de sujeitos aprendizes e mestres, envolvidos nos processos de ensino-aprendizagem do curso primário.

São textos e trechos escritos em diferentes tipologias, ou seja, expressos em diferentes gêneros textuais e são revestidos de conteúdos escolares, voltados para a formação escolar de crianças e jovens. Com essa missão, os textos dos livros "Páginas Brasileiras" irradiam discursos a respeito do Brasil, da educação escolar, a constituição de ser aluno e do lugar do professor, como "representações" que perpassam pelo saber escolar deste momento em que circularam os livros "Páginas Brasileiras".

A análise dos gêneros textuais centralizou-se nos discursos enunciados pelos textos, observando-se as "vozes" dos sujeitos enunciadores, tendo e lugar sociocultural desses sujeitos, a recorrência temporal sinalizado pelos textos e sua relação com o passado, presente 
e sua renovação com vistas ao futuro. A relação do texto com o contexto educacional e a formação de crianças, adolescentes e jovens em Belém do Pará.

O Terceiro Livro Páginas Brasileiras (1967), se configura como obra didática por apresentar a função de instruir conteúdos definidos para o ensino de uma série específica. Em geral os livros escolares de série graduadas reuniam coleções de livros para darem atendimento ás diferentes séries e por serem norteados pelo sistema de ensino vigente, se tornaram referências às práticas educativas de professores e alunos em suas atividades diárias de sala de aula. Como afirma Choppin (1992), são concebidos com uma intencionalidade mais ou menos explícita ou manifesta pelas orientações ideológicas do seu tempo e pela escrita impressa compacta intensificam e disseminam os conteúdos educativos.

Ao analisar o livro em questão, os textos referidos neste volume apresentam-se demarcados por uma concepção de educação centrada nas exigências de sua época, a formação cívica e moral do novo cidadão. O que transparece nesses textos didáticos uma interlocução com outros discursos de tempos anteriores a circularidade desta obra didática. $\mathrm{O}$ que nos leva a compreender a interdiscursividade da fala escrita de Ester Nunes Bibas. Discursos então, reafirmados e validados pelos discursos pedagógicos da autora através de seus enunciados textuais. O livro e seus textos didáticos revelam um movimento de discursos e interdiscursos, que se ampliam no contexto dialógico na sala de aula, nos processos de ensino-aprendizagem, envolvendo professores e alunos. O que se encaminham para uma compreensão a partir de Bakhtin (1992) a respeito do discurso e seu contexto polifônico.

\footnotetext{
Não existe nem a primeira nem a última palavra, e não há limites para o contexto dialógico. Nem os sentidos do passado, isto é, nascidos no diálogo dos séculos passados, podem jamais ser estáveis: eles sempre irão mudar no processo de desenvolvimento subsequente futuro do diálogo. Em qualquer momento do desenvolvimento do diálogo existem massas imensas e ilimitadas de sentidos esquecidos, mas em determinados momentos do sucessivo desenvolvimento do diálogo, em seu curso, tais sentidos serão relembrados e reviverão em forma renovada. Não existe nada absolutamente morto: cada sentido terá sua festa de renovação Questão do grande tempo (BAKHTIN/VOLOSHINOV, 1979, 1992b: p. 410).
}

Esse livro traz como texto de abertura os "Mandamentos Escolares" escrito na primeira página e emite todo um direcionamento sobre a educação, sobre o papel do professor, o papel da escola e o papel do aluno. O texto traz um tom injuntivo, ao instruir, ordenar e prescrever normas a serem adotadas pelos estudantes paraenses através de um texto sob a formatação de decálogo para normatizar as relações educativas, enquanto verdade suprema e inquestionável a ser seguidos. 
Texto 1: Mandamentos Escolares.

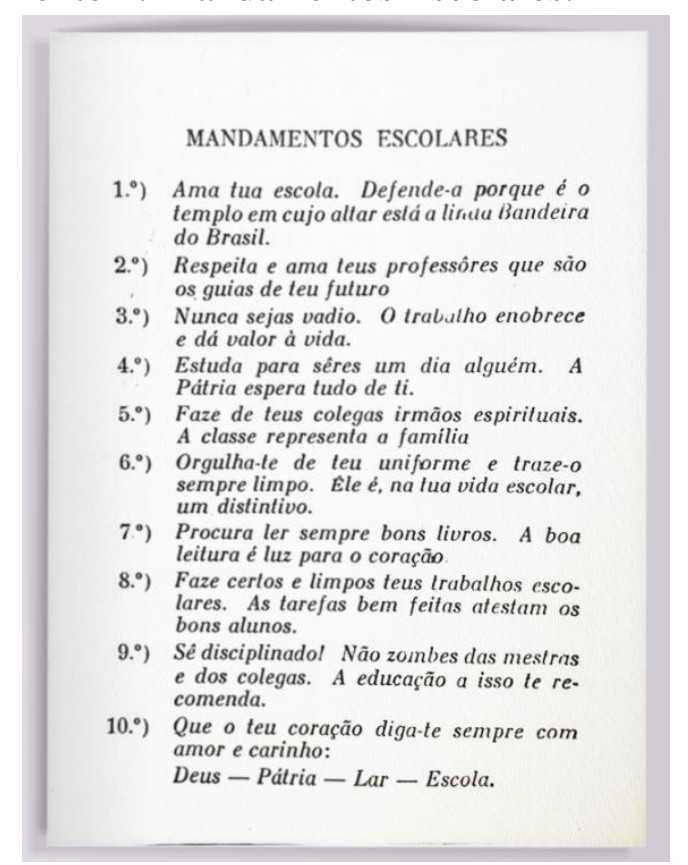

Fonte: (BIBAS, 1967, p. 7).

Ester Nunes Bibas traz para o campo escolar o texto "Mandamentos Escolares", segundo a formatação estética, inspirada em "decálogos" como forma de estabelecer normas e caminhos estratégicos para o alcance de um bom desempenho nos estudos escolares, centrados em discursos reguladores do agir humano. Este texto é predominantemente marcado pelo tom impositivo e indicativo de ação como resposta. De um lado, revela o lugar de quem fala pelo reconhecido saber e assim sujeito de conhecimento e autoridade para enunciar e orientar seu leitor-aluno sobre a maneira de ser, aprender e cumprir o que lhe está sendo ordenado. Do outro lado, os sujeitos, dos quais, se espera um agir conforme o instruído: as "mestras" vistas como "guias" e assim o papel de orientadoras do processo de aprendizagem e da formação moral de seus alunos; dos estudantes, espera-se, o esforço, o empenho em ser bom aluno e o cidadão que a nação requer.

Um texto notadamente marcado por uma fala incisiva do autor é desmobilizado desse caráter monológico, pois segundo o pensamento de Bakhtin (1996), ao ler e ou ouvir os enunciados textuais, o aluno se vê diante da expectativa esperada pelos mestres e pela escola, ainda que essa resposta se organize pela "compreensão passiva das significações do discurso ouvido é apenas o elemento abstrato de um fato real, que é o todo, constituído pela compreensão responsiva ativa (BAKHTIN/ VOLOSCHINOV, 1996, 291).

O texto traz um discurso que enuncia uma visão de ser estudante e de uma conduta diante da escola que o recebe, do ideário da Pátria e seu maior símbolo, a Bandeira Nacional, 
o valor dos estudos, além se enfocar as mudanças necessárias para o sucesso nos estudos, no futuro como trabalhador e na vida social.

No âmbito da educação escolar localizamos "Os Dez Mandamentos da Aprendizagem" de Juan Ignácio Pozo (2002), voltados então, para a atuação de "Aprendizes e Mestres", como preocupações que se transformam em regras de condutas a serem praticadas e enunciam normas e valores que predizem comportamentos a serem seguidos.

No campo educacional, os mandamentos impõem proposições e ou recomendações aos estudantes, que devem segui-los se assim desejarem. Segundo Pozo (2002), os mandamentos servem para "evitar o pecado e a eterna condenação de se aborrecer e de fracassar ao tentar aprender o que outros aprendem". (POZO, 2002, p. 19) O que transcreve a preocupação central com a aprendizagem do que é ensinado pela escola e pelos mestres, o que coloca a formação escolar numa relação dicotômica, em que a escola ensina e o aluno tem a obrigatoriedade de aprender. E nesse aprender, seguir normas e trajetos para o alcance do sucesso escolar. O que não descarta a existência relacional de mestre e aluno, como sujeitos de saberes, sinalizando na verdade o lugar de poder e destaque na enunciação do saber escolar.

Os "Mandamentos Escolares," circunscrito em "Páginas Brasileiras", a autora se pauta num modelo padronizado de decálogos, e emitem como tal normatividade de condutas, expressando um estilo performático que imprime ordem e ou determinações a serem cumpridas. Assim, este gênero textual cumpre uma função a ser alcançada: normatizar as relações no contexto escolar e localizar o lugar e o papel do estudante. Pois, cada tipo de gênero cumpre:

Uma dada função (científica, técnica, ideológica, oficial, cotidiana) e dadas às condições específicas para cada uma das esferas da comunicação verbal, geram um dado gênero, ou seja, um dado tipo de enunciado, relativamente estável do ponto de vista temático, composicional e estilístico. (BAKHTIN, 1997, p. 285).

A palavra escrita se torna um instrumento importante de poder ao impor, determinar, orientar, sugerir, dependendo do contexto em que se dá o processo de enunciação. Os gêneros textuais, nesse contexto, expressam sua formatação linguística e seu conteúdo ideológico; pois, "A estrutura da enunciação e da atividade mental a exprimir são de natureza social [...], pois toda palavra é ideológica e toda utilização da língua está ligada à evolução ideológica" (BAKHTIN/VOLOCHINOV, 2009, p. 126).

Este texto em seu estilo estabelece uma relação de aproximação com "Os Dez 
Mandamentos", enquanto ensinamentos religiosos, e assim, transparece alicerçado e associado à base moral do Cristianismo, Judaísmo e Islamismo, enquanto instituições religiosas, que tiveram e continuam tendo o poder e o reconhecimento do papel normatizador. Uma associação ao contexto religioso, em que a palavra, o "verbo" é revestido de poder e de autoridade, tornando-se referência de comando para orientação do agir humano. Então pautados em princípios que norteiam a vida material e espiritual, ordenações e sinalizações da vida cotidiana, escolar pelo viés da vida religiosa.

Além dessa associação religiosa, o texto em análise apresenta de forma enfática o discurso moral, cívico e ideológico para a formação educacional de crianças e adolescentes, interlocutores presumidos desta intencionalidade. Discurso político-ideológico ufanopatriótico dos tempos da Primeira República, ainda que recuado ao tempo de circulação deste livro, ganha destaque e se renova pelo viés do ideário nacionalista desenvolvimentista então, marcante no contexto político-econômico da Segunda República. O que reafirma discursos do passado no contexto presente da escrita desta autora. Discursos que se adequam à crença salvadora da nação pelos caminhos do desenvolvimento econômico capitalista, promotor do progresso, da industrialização e da modernização do país.

Contexto político e ideológico que atribui à educação um papel estratégico na divulgação da ideologia liberal. A educação nacional se reveste nesse momento de institucionalidade e campo de investimento pelo Estado pela focalização da escolaridade, para tal, lhe direciona reformas, programas curriculares, formação de professores com vistas implementar uma escola nova e um novo ensino que reforme e adeque os sujeitos diante das novas necessidades trazidas pela modernidade.

O primeiro Mandamento traz como norma: "Ama tua escola. Defende-a porque é o templo em cujo altar está a linda bandeira do Brasil." Neste brado de ordenação, os "Mandamentos Escolares" se constituem referencial importante para compreensão dos princípios educacionais e individuais a serem valorizados pelos alunos". A escola aparece com um significado envolto de um templo, um "altar" como afirma a escritora, enquanto lugar sagrado do conhecimento e lugar que referencia a posição central da "Bandeira Nacional," símbolo maior da Nação, nessa relação de importância, o papel significativo da escola para a formação do cidadão. A autora se refere com veemência ao papel da escola e dos professores, mestres expressos no segundo mandamento: Respeita e ama teus professores que são guias do teu futuro", destacando neste mandamento, o lugar reconhecido da atuação escolar e em especial dos professores na condução e transformação dos alunos, condições indispensáveis para o futuro da nação brasileira. 
A menção à bandeira brasileira e a associação ao lema subtendido "Ordem e Progresso" historicamente circunscrito a era republicana, denota um valor pátrio referenciado por um contexto histórico localizado e demarcado pela influência do pensamento positivista, enquanto pensamento paradigmático norteador de diferentes esferas da nação brasileira. Pensamento que será abraçado por políticos, estudantes, militares, jornalistas e outros profissionais, que se engajaram no processo de proclamação da República, como proposta política de mudanças rumo à inserção do país no cenário da modernização, do progresso e da industrialização, ideário pautado nas bases do liberalismo e do positivismo ${ }^{10}$.

Por Positivismo, compreende-se, agora de modo amplo, a filosofia desenvolvida por Augusto Comte que se caracterizava, conjuntamente, pela expressa confiança nos benefícios da industrialização, no otimismo em relação ao progresso capitalista, no culto à ciência e a valorização do método científico, voltados a uma reforma intelectual da sociedade (COTRIM, 1993, p. 189).

O positivismo se disseminou em outras áreas e de forma veemente no campo da educação nacional, se tornando a matriz ideológica norteadora das políticas educacionais, que se reorganizam com vistas a uma formação escolar positivista, na qual, as praticas educativas e os saberes escolares passaram a ser conformados segundo as demandas republicanas para inserção do país no contexto de modernização capitalista. O termo modernização como sinônimo de industrialização, assim o ideário liberal se distinguia do sentido avançado ou de democratização e os proceessos educacionais se davam pela ação instrucional, pela ação disciplinar e pela atuação do Estado, enquanto pedagogia liberal tradicional.

O terceiro mandamento "Nunca sejas vadio. O trabalho enobrece e dá valor a vida"; refere-se, ao alcance da formaç males a ser resolvido no país e consequentemente, esse processo de letramento associado à incorporação dos ideários civilizatórios e de modernidade. Nesse sentido, tais ideários passaram a ser frequentemente justificados por textos e discursos que reforçavam o gosto pelos estudos, como condição para o alcance de uma cidadania positiva para ser alguém reconhecido como importante para a nação brasileira.

$\mathrm{O}$ que demonstra o contexto social e econômico de uma sociedade que impunha a bandeira do progresso e da modernização e sua consequente inserção no mundo capitalista mais ampliado, como justifica a exigência do esforço, do empenho individual em prol do

\footnotetext{
${ }^{10}$ Liberalismo e Positivismo, como bases do autoritarismo politico, a defesa dos interesses privados dos grupos oligárquicos e empresariais aliados à valorização da modernidade, do sentimento prátrio, da família, da religiosidade na busca de legitimação.
} 
progresso da nação, como expressão de amor à pátria. Uma conduta que se alia aos estudos para ser "alguém". Na verdade, os estudantes do ensino primário recebiam uma educação elementar "Ler, escrever e contar", como qualificações mínimas para o ingresso no mundo do trabalho, o que caracterizava uma formação escolar não visava alterar o lugar e as condições sociais das classes populares inseridas nas escolas públicas. Neste contexto formador dos novos sujeitos, a missão da instrução pública, a redenção desses sujeitos e da nação pela incorporação de novos padrões comportamentais segundo os parâmetros da civilidade convocada pela modernidade.

O quarto mandamento "Estudas para seres alguém na vida. A Pátria espera tudo de $t i ”$. Traz o discurso recorrente do valor ao estudo e ao amor à Pátria, como condições inalienáveis para ser reconhecido como alguém. Recorrente e complementar ao mandamento anterior, que substanciam a importância do estudo, do trabalho pelo amor incondicional à Pátria, Pensamento que atribui à educação uma função redentora do novo cidadão e da sociedade em suas condições de subdesenvolvimento que a partir de uma educação reformadora do indivíduo alçar o progresso da nação.

Condição escolar é amainada pelo discurso trazido pelo mandamento de número cinco: "Faze de teus colegas irmãos espirituais. A classe representa a família". O que traz as prerrogativas da convivência familiar a serem incorporadas nas relações sociais entre os sujeitos localizados no cotidiano escolar, como reforço ao ideário de que as relações familiares, harmonizadas e norteadas pelo respeito e pelo amor fraterno. Assim o valor do ideário sobre a família como a base de sustentação da sociedade.

Na sequência os mandamentos correspondentes ao número 6,7 e 8 , se direcionam para condutas higiênicas com relação à conservação e limpeza do uniforme e os cuidados com os trabalhos escolares. Uma preocupação associada à concepção higienista, que perpassava pelos cuidados com a saúde do corpo e a recomendação da escolha de bons livros e boas leituras como referências de ser bom aluno, insere-se também, como cuidados com saúde da mente. Pois, a escola seria o lugar de "reforma" de estudantes, vistos então, como fora dos padrões sociais e culturais. Nessa apreensão, José Veríssimo, em seu livro “A Educação Nacional”, a educação escolar tornou-se veículo enunciador do projeto higienista diante das exigências focadas na modernidade da nação brasileira. Para as quais, a educação, assume o caráter reformador das crianças e do povo brasileiro.

A educação da criança, e mais a educação de um povo, que é a coletividade de inúmeras crianças tornadas homens, para ser perfeita e completa e dar quanto dela se espera, deve começar gerações atrás, para utilizar também, não só a escola, que é 
obra de momento, e apenas um dos fatores da educação, e por si só insuficiente, mas as aptidões adquiridas dos seus progenitores e as granjearias da sociedade cuja é (VERÍSSIMO, 1985, p. 33).

A educação higienista, visto como projeto de intervenção político-social, visando alterar hábitos e condutas culturais para o alcance de novos padrões de saúde. Ester Nunes Bibas ao reforçar os cuidados com o uniforme escolar e o hábito de boas leituras, associa-se a esse projeto higienista, como indicativo de mudanças de condutas pela incorporação de hábitos sadios e dessa maneira alcançar a preservação da saúde física, mental e moral, condições necessárias para o combate á doenças e para a formação de crianças em direção a uma prontidão para o futuro trabalhador. Observando-se que o livro didático Páginas brasileiras se direcionava para os alunos da escola pública, oriundos das camadas populares e em sua maioria vivendo em condições sociais precárias.

No $9^{\circ}$ Mandamento escolar: Sê disciplinado! Não zombes das mestras e dos colegas. A educação a isso te recomenda. a ênfase "Se disciplinado", no sentido de ser educado, respeitador e não ultrapassar os limites estabelecidos no contexto escolar; seja em relação aos mestres e em relação aos colegas de classe. O controle e a disciplina como mediador das relações sociais. Neste contexto, os dirigentes republicanos atribuem um lugar de centralidade à educação e a formação de crianças e adolescentes nos fins do século XIX e início do século XX. Um formato de educação voltada para a formação escolar e para a constituição de alunos/sujeitos obedientes, e sua adequação a ser um futuro trabalhador e cidadão brasileiro disciplinado.

O $10^{\circ}$ mandamento: "Que teu coração diga-te sempre com amor e carinho: Deus Pátria - Lar - Escola”. Faz uma síntese do pensamento e do ideário, para os quais, alunos e mestres devem focar o olhar, como centro irradiador de sentidos e significados para a vida centrada nos valores religiosos, e patrióticos, como pilares formadores do sentimento de pertencimento religioso e de nacionalidade, que se mesclam na constituição identitárias dos sujeitos em formação escolar. O Lar e a Escola, lugares de formação de bons princípios e saberes para a preparação dos novos estudantes e dessa forma, romper com o analfabetismo e a inadequação das camadas populares pelo processo escolar cívico e moral e neste processo:

[...] a centralidade atribuída pelos republicanos à educação, na transição do século XIX para o século XX, nutriu-se dos ideais liberais e dos modelos de modernização educacional em voga, nos países ditos civilizados, ratificando a distinção entre educação do povo e educação das elites e estabelecendo livagens culturais significativas (SOUZA, 2008, p. 19). 
Uma formação do novo cidadão, este deveria ser visto a partir do esforço pessoal e pelo trabalho para romper com o ócio, a vadiagem e a improdutividade por parte do aluno. Pelo esforço, estudo e trabalho, condições ordenadoras para ser alguém no contexto nacional e local. No olhar desta professora, esse empenho seria identificado pelo portar-se bem como aluno ao manter o uniforme limpo e em ordem e a ênfase a leitura de bons livros como “iluminação para a mente e o coração". A realização das tarefas escolares também vista como condição precípua da qualificação do aluno alcançada pelo disciplinamento dos alunos em relação á escola, aos mestres e aos colegas, condição para a instauração de um clima familiar na escola, que seria somente alcançado pela fé em Deus, pelo respeito à Pátria, ao lar e a escola.

Rosa de Fátima Souza (2008) compreende que, a escolarização cívico-patriótica do cidadão republicano esteve subsidiada pelas possibilidades de integração social e pelo contexto de afirmação da nação como projeto político, como também pelo incentivo aos conhecimentos científicos, a modernização das técnicas, as letras e as artes, como ação do Estado brasileiro, "na constituição de culturas escolares distintas configuradas em diversos tipos de estabelecimentos de ensino e em modos diferenciados de distribuição e apropriação do conhecimento e de produção de disposições, de percepções de mundo e de pessoas." (Idem).

Todo esse sentido de modernidade expresso por Souza (2008) sinaliza a ideologia dominante dos tempos de avanço culturais e de uma sociedade moderna, defendida e justificada pela visão positivista do capitalismo, que responsabiliza a atuação da escola pela ministração de uma educação liberal, focada para a qualificação de mão de obra para o mercado brasileiro. Com vistas a expansão econômica e pela circulação dos ideários capitalistas, que exigiam renovação da educação e reformulação de hábitos e condutas inadequadas para este modelo construtor de práticas sociais e econômicas com vistas a expansão e acumulação do capital. Um ideário que ganha guarida no pensamento de Ester Nunes Bibas em sua obra didática produzida, impressa e circulada entre as décadas de 19501960.

Texto 2: Brasil e Texto ${ }^{\circ}$ 3: Ser Patriota.

Os textos "Brasil" e "Ser Patriota", a ser descrito e analisado a seguir, reforçam a questão destacada já no primeiro texto, a respeito de uma educação cívica do cidadão brasileiro e de forma localizada, o cidadão paraense. São textos que se complementam pelo reafirmar do sentimento patriótico evocado por ambos os textos: 
Texto 2: Brasil

Pátria bonita e idolatrada [...] País dadivoso, possui terras onde o brasileiro pode trabalhar, para ajudar o progresso e a civilização [...] De Norte a Sul o Brasil é esplêndido [...] Devemos sentir orgulho, ao dizermos: Sou brasileiro [...] O solo de nossa Pátria é fecundo e oferta-nos sempre flores bonitas e frutos alimentícios, além de palmeiras verdes e belas, que sacode as palmas, nos dias claros de verão [...] Sejamos, portanto, bons brasileiros, trabalhemos pelo nosso país, procuremos descobrir mais e mais suas grandes riquezas [...] Então, sorridentes, satisfeitos, digamos com orgulho e veneração: Sou brasileiro! (BIBAS, 1967, p. 14).

\title{
Texto 3: Ser Patriot
}

\begin{abstract}
O Brasil precisa(va) de bons brasileiros, de verdadeiros patriotas [...] O que é ser patriota [...] é amar realmente sua pátria e desejar servi-la de algum modo [...] As crianças servem a Pátria sendo bons estudantes, já que o estudo é a única responsabilidade da infância. Ser bom estudante é fazer diariamente, os seus deveres, estudar as lições ensinadas em aula pela professora, ser disciplinado, obediente e respeitador dentro de sua escola [...] Todo bom estudante serve ao Brasil e a si próprio, pois prepara o seu futuro, que só poderá ser feliz [...] Procurai servir ao Brasil, como verdadeiros patriotas, adquirir uma religião e uma moral, os princípios básicos que moldam as consciências dos cidadãos honestos e cumpridores de seus deveres (BIBAS, 1967, p. 62, 63).
\end{abstract}

Os textos reproduzem uma imagem do Brasil e de ser brasileiro, sendo que o texto 02 descreve e exalta a grandiosidade territorial, a beleza e as riquezas naturais que enaltecem o país. A autora mediante uma visão romantizada e poética pela exaltação do belo emite um discurso que se encaminha pelo dito e pelo não escrito, que remete para uma percepção sublinhar sobre a realidade do país nesse momento, que se pautava numa imagem de Pátria grandiosa, não somente pela beleza, mas por suas potencialidades de desenvolvimento. No entanto, uma imagem distanciada ou desfocada da concretude societária em sua cotidianidade, ou seja, na vida do povo brasileiro, emitindo um discurso ideológico, pensado e direcionado para serem apropriados e seguidos pelos sujeitos presumidamente, os estudantes. Esse texto ecoa uma visão positivada da Nação brasileira, referendada pelas belezas naturais incontestáveis e assim, o necessário esforço a ser realizado pelo alunado e pelo povo para o alcance de um patamar moral, cívico e cultural para fazer jus a "cidadania" brasileira. E somente pela via da educação os alunos poderiam galgar um lugar social e uma autonomia, como condição de ser alguém na vida e para a nação.

O texto 03 fala do dever do cidadão em amar e venerar a Pátria brasileira para além da condição de cidadania e das condições circunstanciais em que se dá esse processo. O amor á Pátria, o enaltecimento dos símbolos nacionais, como preocupações centrais nos textos presentes no Terceiro Livro de Ester Bibas. Neste terceiro texto selecionado, o reforço ao 
processo de internalização do lema pátrio, como suporte ideológico, pois "amar" é sinônimo de "servir" á Pátra. Enquanto crianças, o dever pátrio de estudar e aprender o que é ensinado. A professora, como mestra que forma e educa as crianças e adolescentes, ou seja, um discurso que reverbera sobre o papel da mulher que estudou para ensinar a nação. Sendo reafirmada a função estratégica da educação pelo ideário pedagógico renovador de tendência liberal como suporte ideológico para amenizar e ou resolver os problemas de ordem políticas, sociais, pela formação cívica-patriótica do cidadão brasileiro, como valor supremo para a modernização e desenvolvimento da nação

A exaltação à Bandeira, símbolo da nação, como chamamento aos "filhos ao dever" de lealdade e submissão de um povo. Como enunciado revestido de conteúdos temáticos que serão evocados em diferentes textos da autora, pelos sentidos e significados que emanam para a formação dos novos cidadãos e nesse cenário histórico. Assim, tornando-se uma enunciação imersa em um discurso já existente e que continua a fazer-se presente de maneira significativa num determinado momento social e histórico, por estar associado á "milhares de fios dialógicos existentes, tecidos pela consciência ideológica, em torno de um dado objeto de enunciação" (BAKHTIN, 2002, p. 86).

O papel da escola referendado pelos discursos textuais presentes neste livro didático, continuam a reafirmar a missão de instruir e educar as "massas" o povo brasileiro, com vistas ao alcance de um desenvolvimento e reconhecimento de uma Nação, de um Estado através dos processos de escolaridade como meio de se romper com o analfabetismo, um dos maiores males a ser resolvido no país e consequentemente, esse processo de letramento associado à incorporação dos ideários civilizatórios e de modernidade. Nesse sentido, tais ideários passaram a ser frequentemente justificados por textos e discursos que reforçavam o gosto pelos estudos, como condição para o alcance de uma cidadania positiva para ser alguém reconhecido como importante para a nação brasileira.

Texto 4: Sou Paraense.

\author{
Sou moreno paraense \\ de Belém do meu Pará, \\ Belém, cidade bonita \\ que sempre risonha está. \\ Sou portando da Amazônia \\ a terra dos seringais. \\ que se levanta orgulhosa \\ de perfume de rosais. \\ Sou caboclo, não importa \\ e sou moreno do Norte, \\ bem moreno de verdade \\ mass sou valente, sou forte
}




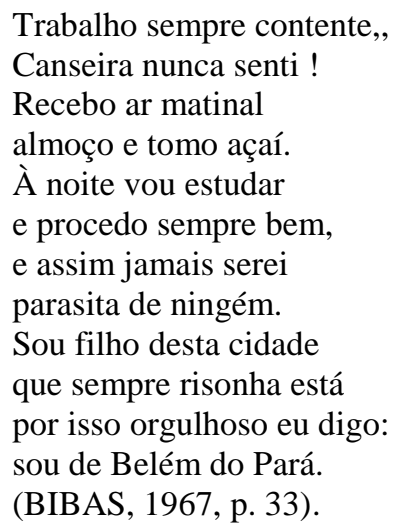

A autora em sua narrativa "Sou Paraense" apresenta uma produção textual sob o formato de poema, e nesta criação estética, anuncia algumas particularidades de ser paraense. A escritora pelo campo da enunciação escrita constitui um personagem revestido de características individuais, com as quais estabelece aproximações às particularidades de um tipo específico de jovem paraense. Ester Nunes Bibas no texto "Sou Paraense", faz referência a um grupo específico de paraense, o jovem estudante da escola noturna em Belém do Pará.

A autora revela ter um prévio conhecimento e proximidade com o sujeito do qual fala e deixa falar em seu poema. Pois, o texto traça e expõe um perfil que identifica sujeitos ou grupos de sujeitos como pretensos estudantes do ensino primário supletivo, para os quais também direciona seu livro "Páginas brasileiras". Questão a ser trabalhada na análise textual propriamente dita.

Inicialmente, o texto insere-se no contexto sociocultural demarcador da realidade paraense e regional. $\mathrm{O}$ que em outros textos deste exemplar, a exaltação a cultura regionallocal, o que define a obra de Ester Nunes Bibas como uma produção didática regional, ao referendar aspectos geográficos, históricos, sociais, ambientais, como marcas da cotidianidade da vida na cidade de Belém.

No texto em análise, a autora estabelece uma ordem discursiva, em que o personagem "paraense" ganha autonomia pela centralidade do discurso direto. Assim, o paraense, conta sua história, se localiza espacialmente, fala de suas vivências do dia a dia. A autora neste contexto de enunciação torna-se onisciente, pois como paraense e atuante do campo da educação, conhece seu personagem, seu pensamento, seu modo de ser e viver, seu trajeto, e direciona ao seu interlocutor o direito a voz, a enunciação, ainda que nesta fala, seja marcada notadamente por respostas, considerando-se na fala do personagem discursos apreciativos, valorativos a respeito do agir como condutas esperadas e valorizadas no âmbito escolar.

A primeira estrofe deste poema em análise "Sou moreno paraense/de Belém do meu 
Pará, Belém, cidade bonita que sempre risonha está." Revela uma marca indelével do paraense, a tonalidade da pele, como referência da etnicidade paraense, o "mestiço". A mistura de raças, como característica do povo paraense, de sobremaneira, das camadas populares, sob a afirmação de grupo "híbrido" advindo do processo de mestiçagem, como identidade sociocultural que aos olhos da sociedade aristocrática belenense se constituía em sujeitos numa condição de um "vir a ser" e para tal necessitava passar uma formação remodeladora para alcançar o patamar de cidadão tanto brasileiro quanto paraense e para tal, deveriam apreender os princípios de civilidade, como afirma Darcy Ribeiro:

[...] Nós, brasileiros, somos um povo em ser, impedido de sê-lo. Um povo mestiço na carne e no espírito, já que aqui a mestiçagem jamais foi crime ou pecado [...] Essa massa de nativos oriundos da mestiçagem viveu por séculos sem consciência de si, afundada na ninguendade (RIBEIRO, 1995, p. 453).

Para Darcy Ribeiro, a mistura de raças constituiu a mais rica arquitetura brasileira pela expressividade cultura do povo brasileiro. Uma nova forma de compreender o sentido da brasilidade do país. Para esse antropólogo, nesse processo contínuo de mestiçagem os filhos que nasciam não se reconheciam nas mães nem nos pais, eram 'nadas'. A miscigenação vista apenas como ponto inicial em que [...] a mulher indígena, prenhada por um branco, pare um filho. Esse filho quem é? É um fruto da terra, que não se identifica com o gentio materno e não é reconhecido como igual pelo pai europeu, que o trata com desprezo. Etnicamente é um ninguém, por serem filhos de ninguém. No entanto, dessa "ninguendade" de mamelucos, de mulatos e cafuzos nasceu um povo único sem precedentes no mundo, o povo brasileiro (pela) aventura brasileira de se constituir um povo novo, lavado pelo sangue negro e pelo sangue índio [...] como uma província mais rica e mais bela da Terra (Ibidem).

Discurso somente pensado e defendido em prol de uma nação múltipla, com diferentes especificidades na contemporaneidade. E apreendendo-se que a temporalidade trazida pelo texto em estudo, remete a uma temporalidade em que o Estado e a Educação nacional vislumbravam a inserção do país no contexto de modernidade, e assim tornaram-se apoiadores e disseminadores dos ideários progressistas, civilizatórios e higienistas sob o olhar da homogeneização étnica e cultural da nação brasileira.

O texto "Sou Paraense" associa o "moreno paraense" a um pertencimento identitários de sujeitos habitantes de Belém do Pará, sujeitos localizados nos bairros ou regiões periféricas da capital. Ao perpassar por traços culturais de cor alimentação, trabalho e formação escolar.

O trecho a seguir do poema, continua a especificar o tempo-lugar desse sujeito 
paraense. "Sou, portanto, da Amazônia a terra dos seringais que se levanta orgulhosa do perfume dos rosais" O que traz a localização regional e temporal e os associa como terra dos seringais. Nesta contextualização, o texto traz a exaltação á região amazônica e as riquezas naturais, destacando a produção dos seringais, momento em que o estado do Pará e a região Amazônica vivenciaram momentos de crescimento econômico. E a partir de então, Belém, em decorrência da produção gomífera e se constituir porto de escoamento desta produção e outros produtos naturais, moderniza-se e a vida urbana torna-se foco de disciplinamento de seu povo, pela incorporação dos parâmetros de modernidade e de civilidade europeia, especialmente a vida social e cultural francesa. E diante dessa focalização, o povo paraense deveria se mirar na grandiosidade de sua nação: Belém-Pará-Amazônia-Brasil.

A terceira estrofe deste poema "Sou caboclo, não importa e sou moreno do Norte, bem moreno de verdade, mas, sou valente, sou forte.” Traz de forma enfática o discurso já enunciado nas estrofes anteriores; como realce a distinção do paraense, que "soa" como um distintivo negativo "Ser caboclo" e ser "bem moreno de verdade", segundo o olhar da sociedade local, que inferioriza o paraense pobre. $O$ trecho "não importa" tal condicionamento étnico-racial, que o classifica e o segmenta nesta sociedade por lhe impor um lugar social. No entanto, o trecho "mas sou valente, sou forte", transparece como preocupação da autora em incentivar essa juventude paraense a ser valente e forte pelo empenho do trabalho e do estudo, como condições únicas para ser alguém, e dessa forma romper com o não ser ninguém. Ou seja, transparece como maneira de amainar toda essa negatividade atribuída ao paraense das camadas populares, a ser minimizada pela força de vontade, e assim se imbuir de valentia diante das dificuldades enfrentadas pela marginalidade dos grupos populares. Sentidos e direcionamentos que vão se tornando mais claros nas estrofes seguintes deste poema.

Trata-se de uma representação de um segmento de paraenses, que é resultante de processos relacionais. A autora e seus pretensos leitores estudantes se constituem na relação eu e os outros. Que se constituem por algo de fora deles, falas, escritos, diálogos, com os quais estabelecem interação. No campo da linguagem e da escrita, neste caso, a linguagem textual tornou-se o caminho instrumental para a construção do eu e do outro, mediado pelos processos de escolarização. E nesse contexto da fala, a identidade, a alteridade e as marcas da diferença dos sujeitos envolvidos vão se aclarando pelo viés das vivências culturais trazidos a tona pelo campo da linguagem. 
significados são produzidos, posicionando-nos como sujeito [...] A representação compreendida como um processo cultural, (que) fornecem possíveis respostas às questões: Quem sou? O que poderia ser? Quem eu quero ser? Os discursos e os sistemas de representações constroem os lugares a partir dos quais os indivíduos podem se posicionar e a partir dos quais podem falar (WOODWARD, In SILVA, 2009, p. 17).

O sujeito fala sempre a partir de um lugar histórico-cultural específico, que o constitui pela diferença. Os processos de alteridade são reafirmados como condicionamentos sociais mantenedores de processos de domínio e de marginalização que institucionalizam privilégios de alguns grupos e a exclusão de outros.

O cenário apontado pelo texto nos leva a uma apreensão de que ao nominar um lugar específico de um grupo de paraenses na sociedade belenense, demarca também a existência de outros indivíduos e grupos paraenses ou não, nomeados como os outros, outras identidades. Paraenses de localizados na camada dominante, e ou classe média, brasileiros e estrangeiros de outras regiões do país e do mundo capitalista, considerando a sinalização dos "seringais" e que passaram a transitar ou a viver no espaço urbano de Belém no momento de exploração da borracha ocorrido nos fins do século XIX e início do século XX. O que demonstra uma diversidade de expressões culturais.

O texto "Sou Paraense" reforça e reafirma o "paraense da gema" ao mesmo tempo, nos induz a pensar a diferença entre nós e eles, outros grupos e culturas, que de uma forma ou de outra convivem e se relacionam neste espaço sociocultural. No entanto, este gênero textual assume uma função pedagógica através da fala do personagem ao estimular o trabalho e a educação escolar como caminhos para uma redenção social e patriótica dos grupos então classificados como "inadequados" para o futuro de modernização, localizados nos espaços marginais da sociedade local. Assim, apreende-se como respostas do personagem a esses ideários formativos trazidos pelas estrofes:

Trabalho sempre contente, canseira nunca senti! Recebo o ar matinal almoço e tomo açaí./À noite vou estudar e procedo sempre bem, e assim jamais serei parasita de ninguém./ Sou filho desta cidade que sempre risonha está, por isso orgulhoso, eu digo: sou de Belém do Pará! (BIBAS, 1967, p. 33).

A educação escolar no Pará assume a função estratégica a partir do momento histórico em que a Amazônia, especialmente Belém e Manaus nos anos de expansão da economia gomífera, se transformaram em centro comerciais e de escoação desta produção. Momento em que a capital paraense foi revestida de uma nova estrutura urbana sob os moldes europeus, especialmente, o francês, pois a circulação de capitais lhe "proporcionou base financeira e 
política para atuar como vanguarda cultural da região no contexto internacional da Belle Époque". (COSTA, 2015, p. 1 apud SARGES, 2010; COELHO, 2002).

Dessa maneira, a adoção de uma infraestrutura condizente com as necessidades do capital e com essa urbanidade local que exigem uma ordenação tanto espacial quanto social pautada em parâmetros civilizatórios que impõem mudanças e ou readequação dos padrões tradicionais culturais locais; pois, o acesso à modernidade exigia o rompimento do analfabetismo, a inserção da cultura letrada, ainda que minimizada aos grupos populares e condutas adequadas para as necessidades do mercado em termos de produção e consumo.

O apogeu político-econômico local favoreceu para que a educação paraense viesse assumir uma função estratégica na formação escolar e na formação das crianças, adolescentes e jovens. A discriminação dos ideários de progresso e de civilização se tornaram norteadores das práticas escolares. Essa intenção formativa que perpassou pelo governo federal, estadual e local, se materializou pela construção e expansão dos grupos escolares, como modelo institucional das escolas públicas e lugar de ministração dos saberes necessários à formação dos cidadãos brasileiros, como também dos cidadãos paraenses. Observa-se o empenho político e pedagógico para a dinamização e a modernização do ensino primário. Coelho (2008) destaca em sua pesquisa os enfoques da cultura escolar dominante na escola primária no estado do Pará no período de 1920-1940. Estudo que dá conta das normas e legislações que normatizam a organização escolar, a constituição dos saberes escolares, a formação dos professores. O que transparece o lugar especial atribuído á educação no estado do Pará, como campo institucional estratégico para a formação escolar e identitária dos novos cidadãos segundo os parâmetros políticos-ideológicos vigentes, que transitavam entre a Primeira e a segunda República brasileira.

E para tal, a ministração de saberes recheados de "mitos políticos propriamente ditos, as ideologias e as utopias (como) lugares privilegiados na construção de discursos ( Ufanopatrióticos) que correspondem a instrumentos de persuasão, pressão e inculcação de valores e crenças"(COSTA, 2015, p. 11).

Todo esforço se faz necessário. De um lado, a formação mais consistente ao professorado. Às mulheres, as futuras normalistas, a formação acirrada cívica e moral para que viesse então, educar civilizar a nação de um sentimento patriótico inconteste.

A formação escolar para a vida cidadã e para o trabalho ganha nova centralidade e se reafirma a partir da Segunda República, em que as práticas escolares seguem a condução político-ideológicos nacional trazido pelo viés nacionalista desenvolvimentista, marca da direção política do Estado brasileiros a partir da década de 1930. O estado do Pará sob a 
liderança de Magalhães Barata e segundo notas publicadas por Damasceno (2015), se verifica então, a ampliação da oferta educacional, seja pelo número de matrículas ofertadas, seja pelo número de escolas que se ampliam neste momento. O que segundo as observações deste professor, sinaliza a preocupação do governo local com a expansão do processo de escolarização no estado do Pará. Os estudos de Damasceno (2015) demonstram que a preocupação com o ensino escolar tenha sido lardeada pelos governos dos primeiros tempos da República, a efetividade desse projeto deixou muito a desejar, pois se tratando das dimensões geográficas do estado do Pará, os lugares mais distanciados não foram alcançados pelos processos de escolarização, segundo os parâmetros então propagados. Para este pesquisador a oferta de matrículas entre 1929 a 1936 se ampliam em torno de $242 \%$, o que deixa visível o interesse do governo local em expandir as oportunidades de escolarização.

Ainda pautado nas observações deste pesquisador, a preocupação com a escolarização em nosso estado está associado ás metas da educação nacional com relação tanto ao aspectobarquitetônico das escolas, os grupos escolares, retratados pela funcionalidade como também, pelo aspecto qualitativo do ensino, e que, deveriam ser criados e expandidos no estado pelo esforço conjunto de investimentos estaduais e municipais. Aspectos educacionais também trazidos por PAIVA (1987, apud DAMASCENO, 2015, p. 230).

O contexto educacional então enaltecido pelo discurso do então Interventor Federal Joaquim Magalhães Barata: “As escolas se multiplicam, as matrículas se elevam, o aparelhamento pedagógico melhoram e aumentam" (O Estado do Pará, 26-5-1933, p. 2), são discursos político-ideológicos que reafirmam as ações do regime revolucionário no país, e que estabelecem para a educação pública, o papel de disseminadora dos valores do nacionalismo e desenvolvimentismo do Estado Brasileiro rumo ao progresso, a industrialização e a modernidade do país, por intermédio de conteúdos e práticas tanto de cunho moral cívico, quanto as ações educativas pautadas nas orientações da Escola Nova.

O que reveste o campo educacional de um ideário de uma educação renovada e encaminhada para tanto para o ensino popular, quanto populista. Marcas da política ideológica para a busca de apoio e reconhecimento do governo pelas camadas populares, através dos discursos educacionais e trabalhistas. O que remete para a expansão do ensino noturno direcionado para os jovens trabalhadores ou para sua inserção no mercado de trabalho.

A autora no texto "Sou Paraense" traz a história do povo e a fala do povo que segundo Certeau $(1982$, p. 8,10$)$ "não existe senão fora dela mesma", ou seja presente no discurso de outrem, que a decodifica, a partir do que sabe ou do que "dele é visto" ou "o que dele é 
sabido". A autora com sua escrita intermedeia a ausência do outro (o paraense) e estabelece uma fronteira e uma separação entre a sua tradução que contém seu discurso e o corpo mudo que lhe dá sustentação, o aluno paraense do ensino primário noturno.

Texto 5: Deus.

\begin{abstract}
Ajoelhemo-nos e oremos. Quando elevamos assim, ao céu, nosso pensamento, sentimos na alma a confiança absoluta, que somente a prece pode oferecer a quem é verdadeiramente cristão. A fé eleva, reanima e alivia a dor. Pela fé, vamos ao Pai, pedimos e alcançamos, porque Êle é o amigo de todos os momentos de nossa vida, dando-nos exemplo de humildade e paciência. Acreditemos em Deus por que Êle existe. Invoquemo-Lo no silêncio e, juntando nossas mãos, agredeçamos os benefícios recebidos, guardando no coração o lugar mais puro, para conservar o seu nome sagrado. Humilde, chamemos por Jesus, pois, se bem cumprirmos nossos deveres de cristãos, teremos protegendo-nos e abençoando-nos - Deus! E, principalmente, pelos doentes infelizes, que vivem longe do lar, digamos esta prece: O Pão nosso de cada dia nos dai hoje e perdoai-nos as nossas dívidas, assim como nós perdoamos aos nossos devedores e não nos deixeis cair em tentação, mas livrai-nos do mal. Amém. Sacratíssimo Coração de Jesus, tende piedade de nós! (BIBAS, 1967, p. 51, 52).
\end{abstract}

O texto intitulado DEUS, expressa a religiosidade como fator formativo do indivíduo e a prática da oração, como elemento presente na prática educativa da escola. O ensino religioso esteve presente na formação escolar desde os tempos coloniais, entretanto, a implantação e a consolidação do Estado Republicano, gerou debates e confrontos entre liberais, católicos, integralistas e comunistas a respeito da concepção de educação, então proposta pela República Brasileira, concebida como "laica" pela defesa da não obrigatoriedade do ensino religioso e pela emergência de uma educação de qualidade norteada pelas verdades científicas, trazidos pelos ideários liberais positivistas para a inserção da nação brasileira nos patamares da modernidade e da ciência.

Observando-se que a liderança católica sempre esteve atenta e participativa nos movimentos da educação nacional, seu objetivo era restaurar o poder e a influência católica sobre as crianças, jovens e suas famílias, mediante o ensino religioso nas escolas, A exemplo, a presença da Igreja e de intelectuais católicos no Manifesto dos Pioneiros da Educação. Não obstante, seus objetivos somente foram atendidos na Era Vargas, momento político, em que Estado e Igreja reestabelecem uma aliança com vistas à condução política-ideológica, pautada no controle e no disciplinamento do povo. A partir da década de 1930, a Igreja Católica tornou-se a base de apoio pelo retorno do ensino religioso nas escolas públicas, tornando-se de caráter obrigatório pela Constituição de 1934. O trabalho social desenvolvido pela Igreja nas comunidades brasileiras dava sustentabilidade ao governo, por "impedir ideias politicas e 
religiosas" contrárias e, nessa aliança promover a recatolização do país e a expansão do ensino confessional privado. A base do governo era formada por integralistas e católicos conservadores, que aliavam à Ação Integralista Brasileira e a defesa de uma pedagogia de reconstrução da nação brasileira (SILVA, 2012, p.1300,1301).

A Constituição de 1934 referendava: "O ensino religioso será de frequência facultativa e ministrado de acordo com os princípios da confissão religiosa". (BRASIL, 1934, Art. 153), entretanto, de ensino opcional, a Constituição Nacional de 1937, tornou o ensino religioso nas escolas públicas, eixo temático, segundo o viés católico. (BRASIL, 1937, p. 88). Neste momento político, o Estado e a Igreja se aliam para a implantação de um governo centralizador, conservador e contrarrevolucionário pelo viés do uso da força, do amor patriótico e, do trabalho religioso-ideológico, bases do Estado Novo.

No estado do Pará, a partir da década de 1930, a Igreja Católica, apresenta-se como instituição aliada ao governo federal e em apoio ao interventor paraense Magalhães Barata, ainda que pelos trâmites da atuação religiosa, o bispo do Pará Dom Antônio Lustosa demonstra suas preocupações aos posicionamentos da "Escola Nova" em relação ao campo educacional e requer em seu discurso o papel do ensino religioso no processo formador da escola, discurso enunciado em Carta Pastoral em 1932 (LEAL, 2014, p. 46, 47).

[..] é impossível reformar o Brasil sem reformar seus homens. Por melhores que sejam as leis, por mais moderna e práticas que sejam os métodos, por mais engenhosos que sejam os sistemas administrativos, de fiscalizar, de desenvolver indústrias, de difundir o ensino etc., tudo é tempo perdido se o caráter, a consciência do homem estiver corrompida (LEAL, 2014, p. 48, apud LUSTOSA, 1932).

Uma questão assegurada tanto pelo governo de Vargas quanto pelo governo estadual que autorizam o retorno do ensino religioso nas escolas públicas. Pois, segundo Leal (2014), a preocupação com a ordem e com a disseminação da ideologia dominante possibilitou a associação do nacionalismo populista e a ideologia católica, que a partir de então, tornam-se conteúdos a serem ministrados pelas escolas públicas. O bispo Lustosa (1932) faz uma clara defesa da ação educativa a ser promovida pela Igreja Católica na orientação dos fiéis e ou dos pretensos católicos, em sua formação moral religiosa, como ação extensiva de apoio político por intermédio dos preceitos normativos católicos.

Assim como Magalhães Barata, o bispo Lustosa também ia ao encontro do povo, como maneira de estabelecer o combate às outras religiões e ideários considerados extremistas, baderneiros ou revolucionários; uma atuação efetiva tanto política, quanto religiosa, com vistas o estabelecimento da ordem e do controle do povo (Idem). 
Neste contexto, o texto "Deus" de Ester Nunes Bibas revela o reconhecimento do ensino religioso no Pará pautado na tradição católica, pelo reestabelecimento "oficial" das relações Estado-Igreja. Nesse sentido, o texto, além do cunho da religiosidade, ele instrui pela prática do catolicismo, a oração, a petição, o ritual, então, revestidos de valores e normas, enquanto religião nacional, ao mesmo tempo que, descredencia outras manifestações religiosas. Nesse sentido, percebe-se a posição de destaque da Igreja Católica em promover a defesa de uma educação pautada na fé, no nacionalismo, na moralidade e na centralidade da família. São ideários de formação que são atualizados por Ester Nunes Bibas em sua produção didática circulada entre 1950-1960.

Como afirma Silva (2011, p. 371), a educação que se estabeleceu no país não é diferente da educação presente no espaço regional-local, assim, neste texto, a autora dissemina o "caráter catequético" aliado à religiosidade católica em seu aspecto formador como caminho estratégico para a conversão ao catolicismo. Dimensão formativa desde os tempos coloniais e aspecto da formação escolar reatualizado a partir da década de 1930 e Segunda República, o que lhe outorga o papel de um discurso autorizado.

\subsubsection{Análise Discursiva do Quinto Livro "Páginas Brasileiras"}

O quinto livro da coletânea "”Páginas Brasileiras" recebe o subtítulo de "Seleta", por trazer textos e ou trechos de autores brasileiros, regionais e locais, encaminhados à leitura dos alunos da quinta série primária. Este livro apresenta a seleção de 138 textos de 78 escritores, dentre os quais, apresentam-se como políticos, jornalistas, advogados, literatos, professores, religiosos, poetas, filólogos, poetas, como escritores de grande expressividade. São textos literários que perpassam pelos gêneros da prosa, da poesia, de contos e ou textos que expressam pensamentos que perpassam pela concepção de educação, de escola, de professor, o nacionalismo e textos sobre a região amazônica, o estado do Pará, a cidade de Belém, entre outros temas. O quinto livro, por voltar-se para a série final do ensino primário, prima por textos que enunciam a representatividade de Belém, do Pará e do Brasil.

O escritor paraense, Eidorfe Moreira (1979, p.28) assinala que os livros didáticos paraenses, desde os meados do século XIX, já enfatizavam os aspectos da cidade de Belém e do estado do Pará. Como livros que emitiam uma temporalidade histórica e cultural localregional, assim como, a presença de textos literários como textos encaminhados à leitura dos alunos. Aspectos, também observados por este escritor na obra de Ester Nunes Bibas, embora, sem grandes detalhamentos. Observações que se ampliam com o estudo sobre a materialidade 
deste livro e a análise dos gêneros textuais.

Aprendemos com as observações de Santos $(2014)^{11}$, que a relação de proximidade do campo da literatura e do campo da educação se dá por conta dos textos literários emanarem "possibilidades humanamente possíveis" - onde se constituem experiências formativas [...] que interagem subjetiva e objetivamente [...] desenvolvido por construções processuais" atuantes na identificação alteritária entre autores e leitores. Um processo construtor de sujeitos mediados pela leitura e pela escrita escolar (SANTOS, 2014, p. 12).

Neste sentido, na relação educação e literatura, a escola, tornou-se espaço "principal" de circularidade dos gêneros literários. Segundo Fernandes (2013) "promovendo a escolarização do texto literário [...] A aliança estabelecida (é) devido ao compromisso pedagógico que a instrumentaliza (educação) para veicular valores morais" (FERNANDES, 2013, p. 2).

Neste espaço de análise de textos e ou trechos de autores do campo da literatura ou das letras, intencionamos perceber os posicionamentos histórico-ideológicos trazidos pelos textos literários, nos quais Ester Nunes Bibas se associa e se fundamenta a partir da fala escrita de autores reconhecidos e com inserção direta ou indireta no campo político-educacional. São discursos textuais que emitem o olhar a cerca do papel da educação, da escola e dos processos ensino aprendizagem e outros aspectos da formação escolar. São escritos por autores de importância nacional e regional e utilizados neste Quinto Livro de "Páginas Brasileiras", enquanto escritos de homens e mulheres inseridos na cultura letrada erudita, assumindo papel relevante no percurso formativo dos alunos leitores ao sinalizarem a visão intelectual e ideológica de políticos, professores, e escritores e sua interferência no campo educacional brasileiro e regional. Os textos literários remetem ao lugar e o posicionamento de quem escreve, pois:

[...] quem escreve um texto literário não quer apenas dizer o mundo, mas recriá-lo nas palavras, de forma que, nele, importa não só o que se diz, mas também o modo como se diz. A mensagem literária é autocentrada, isto é, o autor procura recriar certos conteúdos na organização da expressão. Múltiplos recursos são usados para isso: ritmos, sonoridades, distribuição de sequências por oposições e simetrias, repetição de palavras ou de sons (rimas) etc. (SAVIOLI \& FIORIN, 2006, p.361).

O texto traz as marcas da construção estética e do tempo histórico em seu autor

\footnotetext{
${ }^{11}$ SANTOS, Hellen Regina Freire de. Defende a relação entre a Educação e a Literatura como percurso de um espaço extraterritorial de possibilidades formativas. Dissertação, UFPE, Recife, 2014.
} 
transita. Ester Nunes Bibas recorre a falas escritas "autorizadas" que reafirmam aspectos ideológicos, sociais e culturais, então, defendidos e circulados no campo da educação, por anunciarem elementos de "elevação e refinamento" para a sociedade. A formação cultural revela-se em Said (2011) como um "teatro em que várias causas políticas e ideológicas se empenham mutuamente." A priori, suspeitamos que a valorização dos textos literários assinalados neste quinto livro esteja associado à inclinação desta autora, que ao longo de sua trajetória constituiu outra faceta de mulher "letrada e versada" pela escrita poética.

Texto 6: O Professor.

Autor: Olavo Bilac

\begin{abstract}
Na cadeira de educador, o mestre recebe a visita de um Deus: é a Pátria que se instala no seu espirito. O professor quando professor sente na sua individualidade a Pátria visível e palpável raciocinando no seu celebro, e falando por sua boca. A palavra que ele dá ao discípulo, é como hóstia que no templo o sacerdote dá ao comungante. É a eucarística cívica na lição a transmutação do corpo, do sangue, da alma de toda nacionalidade (BILAC, apud BIBAS, 1957, p. 68).
\end{abstract}

Olavo Bilac (1865-1918) é literato, neste campo foi contista, cronista e poeta de tradição parnasiana. Tornou-se conhecido como príncipe dos poetas brasileiros e membro da Academia Brasileira de Letras, como a grande maioria dos autores selecionados por Ester Nunes Bibas e, profissionalmente foi jornalista. Politicamente foi "republicano e nacionalista". Sua trajetória e produção poética sinalizam seu engajamento político com o Estado Republicano Brasileiro. Sendo o autor da letra do Hino da Bandeira e escreveu contos e poesias de cunho patriótico enquanto produções voltadas para a leitura e formação infantil. O texto selecionado por Ester Nunes Bibas intitulado "O Professor" de autoria de Olavo Bilac, demonstra a preocupação do escritor com a educação nacional e exalta o papel do professor, como indispensável para a civilização da nação brasileira.

Neste texto, o escritor detalha a concepção de professor e seu papel definido, como sujeito imprescindível para a materialidade do projeto de modernização do país e da construção da nacionalidade brasileira. Com essa projeção ufano-patriótica, o professor em sua função de ensinar, deve se revestir de um sentido patriótico para exercer a função para "civilizar a nação" por meio dos processos educativos e de um saber inerente ao papel de ser professor, pois, esperava-se destes, a educação do povo e o desenvolvimento da pátria. Bilac, como os demais liberais, acreditava que a modernização do país somente seria alcançada através da educação do povo brasileiro, compreendida como meio "privilegiado" para a consolidação da identidade nacional, bem como (para) o desenvolvimento econômico" 
(SOUZA, 2013, p. 7).

No trecho, Na cadeira de educador, o mestre recebe a visita de um Deus: é a Pátria que se instala no seu espirito. O professor para exercer sua função, deve inicialmente se revestir do amor patriótico e se empenhar em nome da Pátria, simbolicamente compreendida como um "Deus" e que tudo deveria ser feito e conduzido em nome e engrandecimento da nação brasileira. Necessita incorporar verdadeiramente seu papel de civilizador da nação, viver, respirar e ensinar em prol da Pátria, como assinala o trecho a seguir, $O$ professor quandoprofessor sente na sua individualidade a Pátria visível e palpável raciocinando no seu celebro, e falando por sua boca. A palavra que ele dá ao discípulo, é como hóstia que no templo o sacerdote dá ao comungante. É a eucarística cívica na lição a transmutação do corpo, do sangue, da alma de toda nacionalidade. Olavo Bilac estabelece uma relação de proximidade entre professor, educador e uma relação entre magistério e sacerdócio pela atribuição do papel messiânico do professor. Um discurso poético eficaz na propaganda republicana e emite uma nova representação do professor, quando este passou a ser responsável pela formação do povo, o formador da sociedade, com a missão cívica e patriótica. "Era pelo professor que se poderia reformar a escola e leva-la a realizar as grandes finalidades da educação pública" (SOUZA, 2013, p. 10, 11).

A escola é comparada a um lugar templário, sagrado, mas com uma missão definida, que é a construção da Nação e da nacionalidade brasileira. A escola é apresentada como um "Templo de Civilização", que num contexto de democratização educacional é organizada para a construção de uma nacionalidade e a formação do cidadão a partir de uma educação imbricada com um ideário político e social de um país que passa a estatizar a escola pedagogicamente renovada para legitimar o poderio do Estado. A Escola passa a ser revestida de um valor social para a constituição e efetivação de um imaginário do regime republicano. A escola republicana traz um papel definido para a garantia da moralização e civilização do povo brasileiro.

Segundo Souza (1998), o projeto republicano se baseava num ideário sobre um povo identificado como "massa sem forma, degenerada e indolente" incapaz de vislumbrar a cidadania por si. Para tal necessitava ser guiada, instruída pelos poderes estabelecidos por este projeto político baseado no controle, na moralidade, no silêncio e submissão coletiva para a instauração de uma nova ordem sociopolítica. Uma formação que se dá mediante a instalação de uma escola racionalizada, em que os discursos da democratização e da renovação como fatores imprescindíveis para a efetivação do ideário republicano. Dessa maneira, se aliam nesse processo, o modelo cultural trazido pelo novo regime subsidiados pelos ideários 
políticos impressos e expressos como princípios pedagógicos. Casando-se os ideários republicanos com os ideários defendidos pela Escola Nova. Ideários presentes em livros, materiais escolares e pedagógicos voltados para a formação dos professores e norteadores das práticas pedagógicas, o que garantia a uniformização do ensino brasileiro em nível local, regional e nacional. Uma atuação pedagógica que passava a ser efetivadas nos grupos escolares, enquanto projetos educativos da Era Republicana.

Em Belém, a educação se pautava no direcionamento nacional e assume a vanguarda na construção de uma cultura ligada aos ideários da nação brasileira em meio ao contexto de expansão, como também de declínio da atividade da borracha, cenário conhecido como Belle Époque, não diferenciado da busca do desenvolvimento, do progresso e da civilização.

Segundo a Revista A Escola (1901), o professor tinha a missão de educar em favor do desenvolvimento da nação, como um verdadeiro sacerdote e como tal, deveria ocupar-se exclusivamente de seu "ofício" e de sua elevada "missão". Ou seja, uma "representação coletiva" sobre classe dos professores, enquanto identificação simbólica de gestos, atos e saberes intelectuais a serviços dos interesses majoritários da nação e dos processos de dominação.

Texto 7: O Sacerdote, O Lavrador e o Mestre.

Autor Rui Barbosa

A fronte do sacerdote se verga para o cálix consagrado. A do lavrador para a terra. A do que espalha o grão da verdade, para o sulco soaberto das consciências novas. E os três receberam ordens sacras. Todos concorrem para a fecundação divina do universo. A hóstia, o arado, a palavra, correspondem aos três sacerdócios do senhor. Mas a suprema santificação da linguagem humana, abaixo da prece, está no ensino da mocidade (BIBAS, 1957, p. 11).

Texto 8: Pátria.

Autor Rui Barbosa

A pátria não é ninguém: são todos e cada qual tem no seio dela o mesmo direito à idéia, à palavra, à associação. A pátria não é um sistema, nem uma seita, nem um monopólio, nem uma forma de governo: é o céu, o solo, o povo, a tradição, a consciência, o lar, o berço dos filhos, o túmulo dos antepassados, a comunidade da lei, da língua e liberdade. A pátria é a família amplificada divinamente constituída, que tem por elementos orgânicos, a honra, a disciplina, a fidelidade, o sacrifício. Multiplicai a família e tereis a pátria. (BIAS, 1957, p. 12 apud BARBOSA).

Rui Barbosa é o autor que inicia o quinto livro de Páginas Brasileiras e apresenta quatro textos, sendo dois referentes à religiosidade (p.9,10), um referente ao professor (p.11) e 
um referente à pátria (p.12). Especificamos o conteúdo temático dos textos selecionados por Ester Nunes Bibas deste autor, considerando a importância de Rui Barbosa no cenário político, jurídico, escritor e intelectual do campo da educação. O historiador liberal Roque Spencer Maciel de Barros (1959) afirma que "Rui Barbosa participou intensivamente das ideias e dos problemas do seu tempo e do seu país" (VENÂNCIO FILHO, 2007 apud BARROS, 1959). Um político republicano engajado com diferentes causas, entre estas, a educação liberal republicana e a institucionalização da escola pública "laica" e obrigatória. Para este político, a escola deveria ser ampliada e reformada para se tornar instituição propagadora dos processos de civilização e da modernidade. A instrução do povo brasileiro destaca-se:

[...] como o eixo da ação pública para formar a razão e a moral de um povo [...] Para completar a civilização, o Estado e as elites econômicas percebem a necessidade de escolarizar, além das elites, o restante da população, sobretudo a população infantil e pobre como uma das formas de selar o desenvolvimento, a pacificação e a ordem interna (SILVA, 2012, p. 3).

Na apreensão de Souza (2013) os republicanos atribuíram ao Estado o papel de criar e manter escolas nos diversos níveis, estas escolas teriam a função de preparar o futuro cidadão para que este viesse desempenhar o papel político que o novo regime destinou aos brasileiros. Sua preparação para o trabalho e para a cidadania, pautada na ordem e no progresso. A atuação da escola foi colocada como prioritária para a salvação do país, visto que a grande maioria da população era analfabeta e desqualificada para o mundo moderno, buscado pelos liberais. Assim, na escola pública, seriam veiculados conteúdos que atendessem ao interesse público (e) velassem pela conservação da ordem e da riqueza burguesa.

O texto O Sacerdote, O Lavrador e o Mestre, de autoria de Rui Barbosa, enuncia de forma veemente, o lugar do mestre e sua atuação valorizada, ao ser comparada como lugar precípuo na formação de "consciência novas", ou seja, as crianças e adolescentes do ensino primário. Uma responsabilidade convocada pelas normas e pareceres da política educacional, que aposta no atuar profissional do educador e da escola na formação moral e cívica dos alunos. A metáfora comparativa utilizada por Rui Barbosa entre o Sacerdote, O Lavrador e o Mestre, remete inicialmente para o reconhecimento de uma prática cotidiana "divina", deixando bem claro que a atuação do "Mestre" como sacerdócio, como doação completa, assim como a vida do sacerdote e do lavrador, ao comparar, a "hóstia", o "arado" e a "palavra" como elementos simbólicos poderosos de renovação, transformação e restauração. Embora, os intelectuais liberais republicanos defendam a reorganização de uma escola laica, 
os ideários republicanos, reatualizam a representação do professor e neste momento das professoras, como sujeitos responsáveis não somente pelo sucesso da aprendizagem de seus alunos, mas como veiculadores dos discursos pedagógicos que dão circularidade a concepção de civilização, de progresso, e de modernidade defendidos como ideários de uma nação da ordem e do progresso e diante dos quais, o sentimento de nacionalidade e de amor incondicional pela Pátria. Um discurso político-ideológico que conforma um patriotismo aquém da liberdade e do direito, ao destacar a formação de cidadãos ordeiros, obedientes e com deveres de honra, de fidelidade e de até sacrifícios para o desenvolvimento da nação.

Real (2013) traz o significado do terno nação, pautado em Hobsbawn (1992), como "um termo utilizado em épocas recentes, por referenciar uma existência necessária de um Estado Nacional [...] Para Benedict Anderson (1989), a nação é uma comunidade política imaginada - e imaginada como implicitamente limitada e soberana (REAL, 2013, p. 31). No caso brasileiro, o significado do lugar da pátria tornou-se referência para organização e efetivação do Estado Republicano Brasileiro. Uma idealização pensada e construída por um movimento político-ideológico com a intencionalidade de estabelecer a unidade política, sua consolidação pelo arregimentar de uma identidade de um povo.

A palavra empenhada de Rui Barbosa e de outras lideranças intelectuais circulou para além do campo político e seus discursos desaguaram no campo escolar como de orientações às práticas pedagógicas. Os textos e pensamentos de escritores "fundadores" da nacionalidade brasileira foram incorporados nos materiais escolares, especialmente nos livros didáticos. Estabelecendo uma interligação entre "política, cultura e educação, [...] a política educacional do Estado que, preocupado com a formação cívica do cidadão, intervinha na programação escolar" (FONSECA, 2009, p. 117-124).

Texto 9: O Trabalho

Autor: Júlio Nogueira

É preciso não esquecer a satisfação com que as pessoas normais se entregam ao trabalho. O repouso bem ganho após o desempenho de tarefa penosa, é um verdadeiro prazer identifica o homem com a vida, fa-lo um entusiasta, um otimista, que se diverte com as menores causas. Os que não trabalham, porque não precisam ou não querem, desde que não estejam arrebatados pelo turbilhão dos prazeres, tornam-se indiferentes a tudo, apáticos, céticos, e não raro enfastiam-se da existência. Assaltam-lhes moléstias estranhas que os homens de trabalho desconhecem, como seja ums espécie de saciedade, de fastio que os leva ao desespero e, por vezes, ao suicídio. Finalmente o trabalho é o equilíbrio, a harmonia da vida. (BIBAS, 1957, p. 78 apud NOGUEIRA). 
A biografia de Júlio Nogueira ${ }^{12}$ pertenceu a Academia Brasileira de Filologia e ao longo de sua trajetória escreveu obras relacionada à língua e a gramática portuguesa. Escreve livros sobre o ensino de português para o curso primário e dicionários, apresentando uma vasta produção. Embora sem uma formação específica, é considerado um filólogo e um gramático. Nasce em 1872 no Ceará e ocupou vários cargos públicos. Sendo professor da Escola Normal do Rio de Janeiro e do Colégio D. Pedro II. As obras "Manual ortográfico brasileiro (1924) e Linguagem Usual e Composição (1929)" foram obras premiadas pela Academia Brasileira de Letras. O que revela o reconhecimento deste autor no campo da linguagem e da gramática.

No texto "O Trabalho", o autor traz uma mensagem valorativa a cerca do trabalho e nessa visão, uma abordagem da importância do trabalho para a existência humana. Embora não haja o registro temporal deste texto, parece conjugar-se com o pensamento de Amoroso Lima:

Qual a razão última de ser do trabalho e das normas que devem regê-lo? A felicidade
humana. O homem não trabalha para se agitar, para aplicar o excesso de seu
dinamismo, para produzir riquezas ou para obedecer a uma injunção divina. O
trabalho não é uma agitação vã, nem uma válvula de segurança, nem um dinamismo
econômico, nem uma penalidade pelo pecado. O trabalho é o caminho para a
felicidade. O homem trabalha para ser feliz. O trabalho é o meio que lhe permite,
moralmente, realizar ou não, as condições essenciais de sua felicidade, vencendo ou
não os obstáculos que por natureza se lhe opõem (PINTO, 2003, p. 3, apud LIMA,
1947, p. 95).

O tema trabalho no contexto de formação escolar se tornou recorrente como conteúdo que atende as demandas postas à escola. Seja para dar atendimento à formação moral individual, seja para dar atendimento aos interesses públicos, o trabalho e o esforço do brasileiro para o engrandecimento econômico da nação. Nesse particular, para dar atendimento ao projeto desenvolvimentista e a riqueza burguesa. Assim, a escola, teria a função de preparar para o trabalho, conformando o trabalhador.

\footnotetext{
${ }^{12}$ Acessada nos registros da Academia Brasileira de Filologia, Rio de Janeiro, ABRAFIL, 2012. Nesse registro apenas sinaliza sua data de nascimento e suas obras e posição ocupada nesta academia.
} 
Figura 13 - Voz da Amazônia

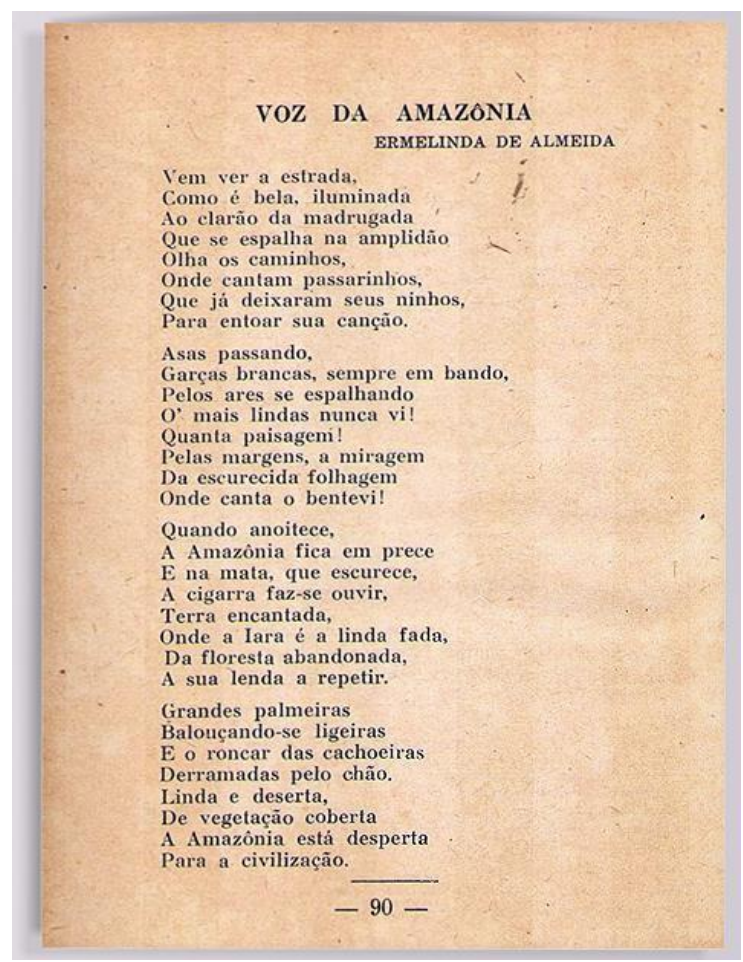

Fonte: Pesquisa de Campo, Fac-símile da obra da Biblioteca Estadual Gaspar Viana, Belém-Pará.

Ermelinda Almeida foi uma poetisa paraense que escreveu, o poema "Virgem de Nazaré" e que por volta dos anos 1960 foi musicado pelo Pe. Vitalino Vari ${ }^{13}$, a partir de então, se tornou um dos hinos executados no Círio de Nazaré. . O que demonstra a vinculação desta poetisa à religiosidade cristã católica. Outras fontes de registro sobre sua produção literária não foram encontradas, mas referenciada pelo livro de Páginas Brasileiras se compararmos com importância dos demais autores selecionados por Ester Nunes Bibas.

Um poema de uma escritora paraense Ermelinda de Almeida e que traz para o quinto livro de "Páginas Brasileiras" o caráter de regionalidade desta obra didática. Ao analisar os livros de Ester Nunes Bibas, identifica-se a recorrência de textos que referenciam a regionalidade amazônica e a regionalidade nordestina. Nesse aspecto, o terceiro livro apresenta 16 textos e o quinto livro, a identificação de 11 textos que apresentam aspectos de caráter local-regional. Segundo Vânia Bibas (2016) como uma das preocupações de Ester Nunes Bibas em "mostrar a cidade de Belém, o estado do Pará e a região amazônica como lugares comuns de Identificação do povo paraense".

O texto Voz da Amazônia, de Esmelinda Almeida traz uma escrita poética que retrata

\footnotetext{
${ }^{13}$ Informação trazida pelo site http://cirio.diarioonline.com.br/guia-tradicoes, 2016.
} 
a Amazônia em sua dimensão natural ou de uma representação de uma Amazônia natureza. Sem uma identificação de uma temporalidade, o poema exalta a beleza natural, por sinalizar os elementos que compõem essa natureza: os pássaros, as garças, as folhagens, as cigarras, a iara, lenda amazônica, a floresta, as cachoeiras. Toda essa beleza natural se junta com o imaginário sobre a floresta e suas lendas. Da beleza materializada a beleza cultural, das lendas e de todo encantamento, que na escrita desta poetiza fala por si. Nos chama atenção a ausência do homem amazônico, talvez, invisibilizado pela grandeza regional, ou destituído de voz ou de pertencimento a essa riqueza natural; pois, segundo a escritora " está desperta para a civilização", ou seja disponibilizada para exploração. O que o texto demonstra a Amazônia, ainda pouco transformada, mas com potencialidades para tal, e pronta para ser civilizada.

Os textos literários utilizados por Ester Nunes Bibas emitem discursos, embora distanciados no tempo de circularidade da obra didática "Páginas Brasileiras, enfatizam inicialmente uma escrita de homens e mulheres letradas e de uma escrita e de uma cultura "erudita", ainda que tratem de conteúdos formativos recorrentes do ensino primário, em que a ideia e o valor atribuído a cultural letrada estava associada à cultura de civilidade, de progresso, de desenvolvimento e de um Estado nacional forte, centralizado e autoritário com poderes de controlar e subordinar as massas populares, por via de ideários políticos ideológicos.

Ester Nunes Bibas em sua multiplicidade de ser mulher, professora e escritora, lhe outorgou outro lugar identitário, de "mulher intelectual", conquistado pelo protagonismo da escrita literária e pela escrita impressa de uma coletânea didática para o ensino primário do estado do Pará. E nesse lugar de enunciação considera-se que:

[...] o discurso/enunciado [...] um fenômeno constituído na e pela enunciação e considerando-se ser esta o ato de um sujeito concreto, situado, pode-se dizer que o estudo da relação entre o discurso/enunciado e o ato da enunciação incide diretamente sobre o próprio ser do discurso (SOBRAL, 2012, p. 119).

Nesta perspectiva, apreender o lugar social e epistemológico de quem enuncia, como lugar revelador do sujeito, do discurso e do meio social, em estrita relação de construção do enunciador e do enunciado. Bartlhes (1975) ao se referir ao professor, considera que o lugar da fala e da escrita encena uma enunciação marcada pela autoridade pelo bem falar e pela inteligibilidade da palavra transmitida; tornando o professor como sujeito propositor de discursos e, que diante dos quais, "ele nunca saberá por quantas escutas variáveis passou [...] uma fala pública [...] fundada na transferência [...] na relação professor e aluno, a ciência, o 
método, o saber [...] que são operados nos encontros com outras falas" (SARNO, 2000, s/p, apud BARTHES, 1975).

São contribuições que levam a uma compreensão de que a voz e a escrita são portadoras de sentidos de vivências e dessa forma, são depositárias de juízo de valor e indicadores dos sujeitos e seus lugares em sua ambiência social, política e cultural que muito dizem a respeito de seus enunciados.

O Lugar de Enunciação de Ester Nunes Bibas.

Ester Nunes Bibas em suas multiplicidades de ser mulher, professora e escritora, the outorga outro lugar identitário, de mulher intelectual, conquistado pelo protagonismo da escrita literária e do produzir uma coletânea didático-pedagógica para o ensino primário do estado do Pará. Nesse lugar de enunciação considera-se que:

[...] o discurso/enunciado [...] um fenômeno constituído na e pela enunciação e considerando-se ser esta o ato de um sujeito concreto, situado, pode-se dizer que o estudo da relação entre o discurso/enunciado e o ato da enunciação incide diretamente sobre o próprio ser do discurso (SOBRAL, 2012, 119).

Nesta perspectiva, apreender o lugar social e epistemológico, do qual enuncia, revelando o sujeito, o discurso e o meio social, em estrita relação. Bartlhes (1975) complementa que o lugar da fala e da escrita do professor encena uma enunciação marcada pela autoridade, pelo bem falar e pela inteligibilidade da palavra transmitida; tornando o professor o sujeito propositor de discursos, os quais, “ele nunca saberá por quantas escutas variáveis passou [...] uma fala pública [...] fundada na transferência [...] na relação professor e aluno, a ciência, o método, o saber [...] que são operados nos encontros com outras falas" (CRISI SARNO, 2000, sem paginação, apud BARTHES, 1975).

Ester Nunes Bibas, mulher, professora e escritora apresenta um percurso histórico de1888 a 1972, sendo fruto do seu tempo e lugar sociocultural que viveu a condicionalidade de sujeito que caminhou entre os limites, os controles e a representação do feminino subalterno numa região colonial, até então, distanciada dos centros econômicos mais dinâmicos do país. Uma localização temporal e espacial que outorga à Ester Nunes Bibas e sua obra como produção local-regional e professora escritora periférica. Entretanto, apesar desses condicionamentos impostos pela cultural dominante local, esta professora alçou voo e alcançou emancipação intelectual. 


\subsubsection{Uma Mulher do seu Tempo-lugar}

A cidade de Belém, nos fins do século XIX experimentou uma "era" de poder e de vivências culturais, que apontou para um novo estilo de vida para a elite paraense, exportadora de borracha. Um cenário marcado pela sociabilidade urbana que neste momento vai revestindo a vida social de requintes, elegância no vestir e de comportamentos e posturas de homens e mulheres educadas e cultas, como expressões do progresso e da civilização. Os ideários civilizatórios, assentados na cultura da belle époque vão se tornando preponderantes em Belém e Manaus, que se transformam em "epicentro cultural dos trópicos”. Cidades localizadas numa região distanciada geograficamente dos grandes centros culturais, e que neste momento, se integram no circuito mundializado da economia capitalista e da cultura burguesa.

\footnotetext{
Transporta-se então, para Belém e Manaus uma identidade urbana europeizada, que vai sendo apropriada pela elite local com relação aos ideários parisienses. Considerando-se que "pelos canais de circulação do capital, circulava igualmente, o discurso do progresso e da civilização, na forma das muitas representações assumidas por esse mesmo discurso" (COELHO, 2011, p. 144).
}

Neste cenário de belle époque, o culto às letras, à música, à poesia, ao canto, à dança se constituíram em expressões culturais da modernidade e passaram a ser incentivadas em Belém pelas associações literárias, pelas agremiações organizadoras de espetáculos musicais, teatrais e culturais, enquanto ambientes de vivências culturais, intelectuais e como novos espaços da sociabilidade urbana. Todo esse dinamismo urbano emerge como reflexo da escala mundial das exportações da produção gomífera e pela concentração da posse dos bens materiais e culturais pela elite paraense.

Em Belém, surge uma diversidade de agremiações culturais representadas por diferentes jornais, grêmios e revistas que em geral, tornaram-se veículos de registros das produções de escritores locais e a publicação de artigos e escritos de autores nacionais e internacionais. Tais veículos e agremiações se revestiram do caráter disseminador da intelectualidade e da cultura na cidade de Belém, a exemplo:

Diário de Notícias, A Província do Pará, Folha do Norte, O Equador, Ordem O Ateneu, A Alvorada, A Revista, O Lábaro, Boemia Literária, O Pará Moderno, O Parnaso, O Extremo Norte, O Boêmio, Pará-Revista, O Ideal, A Voz Literária, A revista do Equador, A Revista Acadêmica [...] Livrarias Tavares Cardoso e Clássica, (os) jornais Gazeta de Notícias, Diário do Grão- Pará, O Liberal do Pará, Progresso, O Jornal, A Tesoura, O Pará (Idem, 2011, p. 155). 
Representado um mosaico de veículos culturais, cuja finalidade era dar atendimento aos anseios de seus criadores e se constituir como meios estratégicos para disseminar os ideários do Progresso e da Civilização. A imprensa local se tornou espaço privilegiado para a publicação de artigos, crônicas e textos literários da então, elite intelectual da borracha. Destacando-se a participação e o reconhecimento de homens escritores, homens de letras e de cultura, homens do mundo da política e de diferentes áreas do saber no cenário paraense.

Coelho (2011) registra como destaque no campo da intelectualidade e da cultura, a atuação de Humberto de Campos, Theodoro Rodrigues, Eustáquio de Azevedo, Paulino de Brito, João Lúcio de Azevedo (e) a participação de homens do mundo da política com inserção no mundo das letras como Antônio Lemos, Augusto Montenegro, Serzedelo Correia, Paes de Carvalho, Américo Santa Rosa, Tito Franco de Almeida, Barão de Guajará, Barão de Marajó, como sócios honorários e referendo político às agremiações culturais belenenses. $\mathrm{O}$ que demonstra nesse "epicentro" cultural, o domínio da cultura letrada masculina, que revestida de reconhecimento impactou a mentalidade cultural local e interferiu na proposição e na efetivação dos processos civilizatórios para o espaço social da cidade de Belém e no campo educacional. Nesse tempo-lugar de domínio do masculino, a ausência de registros sobre a participação das mulheres letradas e intelectuais, num tempo em que o dinamismo social e cultural tornara-se fator de visibilidade dos diferentes grupos sociais Entretanto, em meio aos discursos da modernidade e da formação dos sujeitos republicanos, o espaço urbano belenense manteve-se como território de desigualdade, na medida em que a modernidade referendou os privilégios dos grupos majoritários nas diferentes áreas da sociedade local, e engendrou mudanças locais com vista à construção de um novo cenário a partir do ideário de:

Uma identidade de um tempo, cujos sujeitos sociais emergiram das nossas condições econômicas e sociais dominantes no mundo do capital, (e) a belle époque implica reconhecer linguagens, gostos, atitudes, estéticas, sociabilidades que, construídas em escalas diferenciadas nos espaços hegemônicos da cultura burguesa, reproduziramse, em escala planetária, também na condição das formas de ser e de agir em tempos que abrigaram o proclama do triunfo do Progresso e da sua homologia, a Civilização (ibidem, 2011, p. 141).

O cenário cultural da capital paraense retratava as vivências, os ares e os costumes parisienses, considerados exemplos civilizatórios e de civilização, no entanto, sem promover a inserção da mulher neste contexto de modernidade. Pois, apesar das mudanças em direção à construção de um espaço urbano moderno e culto, não se alteraram as bases conservadoras que sustentavam os padrões culturais amazônicos. Mantendo-se no estado do Pará e na região amazônica, o controle e o poder de mando da elite local, que cerceava a participação da 
mulher no cenário publico.

Os preceitos normativos em relação à mulher mantiveram-se rígidos e com caráter disciplinador do ser-mulher paraense. Uma normatização que perpassava pelo modelo de educação endereçada à mulher. Assim, nos bastidores da belle époque, a sociedade paraense permanecia patriarcal, senhorial, com valores conservadores em relação à família, à mulher e a todos os segmentos sociais dependentes da elite local (CORREA, 2014, p.7).

Os valores patriarcais continuavam a normatizar as relações sociais na sociedade brasileira e na sociedade belenense. No contexto familiar subsidiam e dinamizam as relações familiares, atribuem valoração social, econômica e política aos membros partícipes, constroem redes, teias e laços sociais que garantem a visibilidade e a manutenção do poder masculino. As relações sociais nesse espaço do privado se apresentavam eivadas de poder e subalternização. Fazendo-se presentes tanto nas famílias abastardas, quanto nas famílias destituídas de bens materiais. Desta forma, a dinâmica familiar funcionava como espelho da normatização da sociedade patriarcal nos processos de afirmação, inclusão e exclusão de pessoas e grupos sociais, para a afirmação do domínio patriarcal na sociedade brasileira e paraense (Idem).

$\mathrm{Na}$ Amazônia no início do século XX, as famílias, embora diversas, social e culturalmente, continuavam a representar o alicerce fundante da dinâmica demográfica e espaço de preservação de patrimônios, situando-se como organização social, política e cultural e de expansão das condições sociais, por estabelecerem redes de influências sociais no momento em que o Grão Pará transita por uma reestruturação econômica diante da consolidação da exploração da borracha (Ibidem).

Nesta sociedade tradicional, os valores patriarcais ditavam normas, interferiam nas relações de gêneros, determinavam e classificavam os papéis masculinos e femininos. Um discurso hegemônico que designou e manteve o poder masculinos por décadas e ainda recorrente na sociedade atual. Na sociedade belenense, o papel da mulher era referenciado como filha obediente, esposa e mãe dedicada; localizada numa posição social hierarquicamente subordinada à autoridade e ao poder do homem.

Neste espaço social, as mulheres que se lançaram pelos caminhos da escrita, especialmente pelos caminhos literários, se depararam com a desautorização que negava o direito autoral sobre suas escrituras e o não reconhecimento da intelectualidade feminina, por serem avaliadas e desqualificadas a partir do cânone masculino. No estado do Pará, essa desautorização à autonomia intelectual da mulher manteve a atuação feminina sob a condição de subalternidade. 
Nessa ambientação sociocultural local restou-lhe o apropriar-se dos caminhos autorizados e reconhecidos como campo de formação e atuação feminina, entre estes, os ensinamentos apreendidos na formação profissional para o magistério primário.

\subsubsection{Mulher Letrada: Sujeito epistêmico}

Ester Nunes Bibas, neste cenário educacional, onde a presença e a intelectualidade do masculino são valorizadas pelas autoridades educacionais locais, conclui sua formação de normalista em 1908 na Escola Normal do Estado do Pará, aos 20 anos de idade e se insere no campo da educação, como professora primária no início dos tempos republicanos. Tornandose professora do Collégio Progresso Paraense, colégio considerado como referência na educação de crianças e jovens das classes médias da cidade de Belém (MEIRA, 1996, 127).

Ester Nunes Bibas se insere no campo educacional, num momento em que a cidade de Belém vivenciava um intenso processo de transformações sociais, econômicas, políticas e culturais, advindas das novas demandas do capitalismo industrial no final do século XIX e nos primeiros anos da República, momento em que a educação local assume papel estratégico diante das mudanças locais, tornando-se veículo propulsor do ideal republicano pautado na busca do progresso e no alcance dos padrões civilizatórios para inserção da "nação republicana" no cenário da modernidade. As referências desse cenário político serão elementos interferentes na formação e na atuação profissional desta professora paraense como apropriações pedagógicas demarcadas por discursos ideológicos identificados em sua escrita e proposições pedagógicas.

Nesse sentido, essa mulher, professora-escritora paraense fala do lugar do conhecimento, do saber-fazer e do incorporar competências e habilidades do apreender mobilizados pela formação inicial oportunizado então, pelo curso normal, pelas vivências na cotidianidade da sala de aula e pela troca de experiências entre seus pares que numa relação processual e interpessoal lhe atribui um saber "pessoal" e "profissional" didático-pedagógico enquanto "conhecimentos técnicos, de saberes de ação, de habilidades de natureza artesanal, adquiridos por meio de uma longa experiência de trabalho" (TARDIF, 2014, p. 9).

Tardif (2014) acrescenta que esse saber apreendido e construído pelo docente se estabelece na relação direta com contexto histórico-temporal e com o lugar institucional de formação profissional desse sujeito, construtor de saberes.

A Escola Normal do estado do Pará nos primeiros tempos da República e diante dos projetos governamentais locais de remodelação e modernização da cidade de Belém, passou a 
receber uma atenção diferenciada pelo governo local que reconhece seu importante papel na formação e habilitação de professores e professoras para a educação primária, face as exigências postas a educação para "transformar os alunos, educa-los e instruí-los" segundo a concepção de educação escolar deste momento, apoiada pelas elites locais.

Pautando-se na pesquisa de Tavares Júnior (2012), a preocupação do Estado Republicano e do estado do Pará relacionada a necessidade de habilitação dos professores primários está associado a compreensão de que a escola por intermédio dos professores viessem assumir os encargos de um ensino primário pautado nos ideários republicanos do alcance da civilização, dos conhecimentos científicos, da difusão do higienismo para o progresso da nação e das cidades em processo de urbanização. E nesse sentido o papel deste processo de formação a ser encaminhada pela Escola Normal estava associado à concepção de modernidade segundo Villela (2010):

[...] confunde-se com o fortalecimento dos Estados Nacionais, a partir da denominada Idade Moderna. Inspirado pelo papel das ordens religiosas que se dedicavam a esse tipo de ensino, o Estado tomou para si o recrutamento e vigilância de professores, constituindo-se assim um corpo de profissionais ou de funcionários, mas não uma concepção de ofício (TAVARES JUNIOR, 2012, p. 76, apud VILLELA, 2010, p. 95).

Uma visão formativa que impõe ao fazer profissional a exigência de habilitação, ao mesmo tempo, a exigência de um empenho "missionário", uma visão de uma atuação como "sacerdócio" e, uma missão a ser realizada pelo professor, a partir de seu atrelamento ao discurso oficial do Estado. No campo educacional, professores e alunos, como sujeitos disciplinados como veiculadores de valores morais, cívicos, religiosos, então, pilares de sustentação do Estado Republicano. Ainda sob o olhar de Tavares Júnior (2012), a Escola Normal, tornou-se "viveiros de mestres" conformados e compromissados com a disseminação política-ideológica, que percebe na educação, a formação de um "povo" enquadrado segundo os parâmetros culturais das elites dominantes no país e no estado do Pará.

Ester Nunes Bibas conclui o Curso Normal em 1908, durante o governo de Augusto Montenegro, segundo governador republicano do estado do Pará (1901-1909). Momento de investimento na estrutura física e organizacional da Escola Normal com vistas a modernização do ensino dos alunos normalistas e concidentemente com o processo áureo de exploração e exportação da borracha; o que permitiu criação de novas escolas em sua nova arquitetônica, os grupos escolares. Esta professora, ao ser habilitada como professora normalista num contexto de consolidação da Primeira República. Observemos em sua 
produção textual presente em sua coletânea didático-pedagógica, a evidência de discursos pedagógicos centrados nos ideários republicanos. Acreditamos que essa influência se faz presente em sua obra didática por conta inicialmente pela formação inicial, como normalista, momento de difusão desses ideários, que perpassavam pelas influencias positivistas, tão presentes na liderança político-militar do movimento republicano, o que nos leva a entender a difusão de uma educação tradicional pautada na ideologia liberal.

A formação escolar recebida por Ester Nunes Bibas perpassou por diferentes disciplinas, sobre as quais, Tavares Júnior (2014) elabora uma síntese, que nos permite perceber o conteúdo e a recorrência temática, os quais interferiram na formação desta professora e de seus pares. A Escola Normal apresentava uma grade curricular em que o caráter humanístico é bem demarcado, configurando-se o ensino neste momento:

\footnotetext{
Um conjunto de disciplinas voltadas a preparação de alunos e alunas para a vida em sociedade pretensiosamente de ares modernos civilizados; A(o)s futura(o)s professora(e)s tornar-se-iam agentes reprodutores do projeto de modernização fortemente marcado pela influência estrangeira, principalmente americana e europeia, com ênfase na língua e cultura francesa (TAVARES JÚNIOR, 2012, p. 101).
}

Percebe-se que a formação inicial, ainda faz-se bem representativa na obra de Ester Nunes Bibas em seus textos e nos textos selecionados de autores brasileiros e regionais, que enunciaram temáticas bem recorrentes a esse momento de formação. Entretanto, acreditamos, que Ester Nunes Bibas em sua obra, reatualiza discursos de um passado recente, ao momento em que segundo informações de familiares9, é nomeada como professora do ensino primário na década de 1930, no governo do Intendente Magalhaes Barata, momento histórico em que se inicia a Segunda República, notadamente alicerçada nos pilares do nacionalismo e do desenvolvimento do país, buscado pelo processo de industrialismo nacional, em que o trabalho e o trabalhador, tornaram-se foco da atuação populista do Estado.

\subsubsection{A Palavra Empenhada: discursos autorizados}

Partindo da compreensão de que Ester Nunes Bibas se localiza entre as mulheres nascidas no século XIX e ao transitar pelo século XX, deixaram suas marcas, suas contribuições pelos caminhos da educação. Se revelando assim, um sujeito-objeto a ser investigado, conhecido e valorizado por seus empreendimentos. Uma história particular inserida num cenário histórico, que demarca o papel da mulher numa condição de 
subordinação, controle e submissão. Ester Nunes Bibas em seu lugar social emerge de classes médias e ou "remediadas", mas situada numa realidade societária tradicional que limitava a inserção social e intelectual das mulheres. Ester Nunes Bibas é apreendida como sujeito da palavra a partir de seus escritos, que dão visibilidade ao pensamento e a escrita de sua autoria.

Barthes (2007) afirma que palavra transforma a linguagem em expressões de poder, por impulsionar posturas diante do mundo, da vida e da sociedade. E num contexto formador, a palavra do autor afeta o leitor em suas compreensões de si e do mundo, assim sendo, tornando-se veículo constituinte dos sujeitos em sua subjetividade e objetividade, a partir do estabelecimento de um processo de análise e compreensão dos sentidos e significados veiculados pelo ato enunciativo como lugar formativo para além da leitura pela leitura.

Segundo Bakhtin (1997, p. 206, 209) o autor, em seu ato criador deve situar-se na fronteira do mundo que está criando e considerando-se que esse processo de criação, baseado numa representação do mundo por meio da palavra, como veículo carregada de sentidos ideológicos, pois, a escrita autoral revela a relação do autor com a língua em seu estilo, que dá representatividade da vida e do mundo.

Ester Nunes Bibas se enquadra entre as mulheres que ocuparam que exercitaram o direito da fala e de uma escrita impressa, tanto no campo da educação quanto no campo literário, mas apesar dos condicionamentos culturais percebe-se que mesmo numa condição de subalternidade, de ser mulher de uma região periférica, atuou por entre as possibilidades que se efetivaram pelo seu esforço. Assim, seja pela ajuda familiar, que lhe proporcionou o aceso a cultura letrada, seja pelos caminhos de uma escrita "autorizada", que sinaliza e é sinalizada por discursos de escritores referendados pelo campo político, pelo campo da educação e pelo campo literário. Nesse sentido, sua escrita pedagógica lhe define o lugar de sua fala, o lugar de professora-escritora liberal, arraigada em valores socioculturais tradicionais, ainda bem presentes na cidade de Belém do Pará, no momento de edição e circulação de sua produção didático-pedagógica.

Os direcionamentos político-ideológicos liberais que nortearam sua coletânea didática, não destituem o lugar de professora intelectual do campo da educação e do protagonismo de uma mulher que exerceu uma autonomia do escrever pela construção de seu espaço, de onde exercitou sua fala e se fez ouvir por professores e alunos das escolas públicas do estado do Pará através da circularidade de seu pensamento educacional alcançado pela publicação da coletânea didática Páginas Brasileiras entre 1950-1960. Um pensamento educacional matizado por juízos de valor e pala moralidade vigente, constituindo-se uma proposta de escolarização para o ensino primário subsidiada numa formação moral cívica em resposta aos 
parâmetros norteadores apreendidos e defendidos por esta professora normalista paraense, como intelectual do campo educacional de seu tempo e de uma sociedade em viveu. 


\section{CONSIDERAÇÕES FINAIS}

A narrativa histórica a respeito da trajetória e do pensamento educacional de Ester Nunes Bibas, como ponto de chegada desta tese, foi construída ao longo de um processo investigativo interdisciplinar, oportunizado pelo campo da história cultural e suas vertentes, enquanto campo teórico-metodológico para abordagem, compreensão do sujeito-objeto, assim como suporte para os processos de levantamento de dados, estudo de fontes, registros, relatos e para a análise da coletânea didática Páginas brasileiras focalizada no terceiro e no quinto livro desta coletânea. Um processo que foi sendo alinhavado paulatinamente a partir dos indícios identificados que possibilitaram a apreensão e compreensão do lugar que ocupou a escritora Ester Nunes Bibas e sua produção didático-pedagógica no contexto educacional do Pará. Embora, com plena convicção de que este momento de chegada se constitui uma escrita inconclusa por se tratar de uma professora escritora paraense oculta pelo silenciamento da história da educação. Assim sendo, esta narrativa assinala aproximações sobre os lugares palmilhados e ocupados por Ester Nunes Bibas e suas proposições para o campo da educação primária no estado do Pará entre 1950-1960.

No percurso para a compreensão do cenário social, político e educacional em que circunscreve a vida e a autoria intelectual de uma professora normalista, a questão norteadora proposta pela tese, tornou-se ponto de partida desse empreendimento: Que lugar ocupa a educadora Ester Nunes Bibas e sua produção didático-pedagógica no contexto educacional do Pará? Como questão instrumental que direcionou a investigação, o estudo, a análise e a construção desta narrativa histórica, enquanto escrita acadêmica. Nesse processo pontuamos quatro aspectos relevantes relacionados à trajetória e á produção didática desta escritora paraense, como pontuações que ao longo da caminhada investigativa possibilitaram a sustentabilidade da presente tese.

A primeira pontuação como ponto de chegada, traz a relevância dessa narrativa histórica, ao considerar que a tese tornou-se veículo importante para a retirada da obscuridade a história de vida e o pensamento educacional de uma professora normalista de um tempo, de uma região e de um estado brasileiro, considerado como espaços periféricos, territórios isolados, até então, do cenário geopolítico brasileiro. A tese, ao se situar nesse tempo-lugar propiciou o emergir de uma memória histórica da professora Ester Nunes Bibas, autora de uma produção didática local-regional. Sujeito situado como professora/escritora "invisível" e nessa condicionalidade histórica, a tese traz como principal contribuição a "recolocação" do lugar desta professora e sua obra didática no circuito da história da educação paraense e 
nacional em tempos atuais. Assim, a tese centra-se na atuação intelectual de uma mulher professora normalista do passado, ainda que um passado recente, num estado e numa região em que os registros e fontes documentais foram e continuam sendo pouco valorizados, seja pela ausência de uma cultura de preservação histórica no âmbito público e no âmbito familiar, seja pela não valorização dos escritos e de obras femininas.

A segunda pontuação se refere à Ester Nunes Bibas como sujeito intelectual periférico, inscrito numa realidade cultural conservadora, que caminhou entre as frestas das amarras da subalternidade. Ester Nunes Bibas se constituiu mulher, professora e escritora no decorrer de um longo percurso histórico (1888 a 1972), sendo fruto do seu tempo e lugar sociocultural e, parafraseando Bernardes (1988, p.1), como "mulher de ontem" que viveu a condicionalidade de um sujeito fronteiriço, entre os limites, os controles, a representação do feminino subalterno e o transito pelo possível, numa região notadamente marcada pelo poder e pela valorização da elite intelectual masculina. Se por um lado, a publicação de uma coletânea composta por 05 livros didáticos, nesse contexto sociocultural, a primeira vista, pelo menos, tornou-se um grande feito de uma mulher paraense; por outro lado, a autora ser oriunda de uma região situada num isolamento geográfico, então, distanciada dos centros econômicos mais dinâmicos do país; uma localização geopolítica que atribuiu à região amazônica, o papel de território colonial submetido aos interesses dos centros internacionais e do mercado nacional. A autora se constitui sob as interferências desses processos coloniais, aos quais, foram submetidos o estado do Pará e a região amazônica. Posição que atribuiu a Ester Nunes Bibas, o lugar de sujeito periférico.

Embora, ao longo da trajetória desta professora, algumas saídas foram favorecidas ou encontradas pela professora Ester Nunes Bibas, que lhe permitiu transitar entre as "bordas" do privado e do publico, ou seja, esta mulher, professora-escritora, apesar dos limites advindos de uma cultura patriarcal acirrada, encontrou passaportes para exercer seu protagonismo do escrever. Pois, apesar dos ditames socioculturais, Ester Nunes Bibas exercitou suas potencialidades do escrever desde muito cedo. Consideramos que a habilidade da escrita poética e da escrita pedagógica desta professora normalista, presentes em seus textos de forma muito apropriada, parece estar diretamente associada ao suporte familiar que Ester Nunes Bibas usufruiu desde meninas, a exemplo o apoio da mãe professora que lhe alfabetizou, o pai, político da cidade, dos tios e primos ligados à literatura e sua formação e atuação no campo de educação. Apesar da referência de que os "Nunes" da Vigia eram oriundos de famílias "simples", entretanto se destacaram pela cultura, pela educação e pela escrita poética, conforme relatos de familiares presentes na seção dois, referente à trajetória desta educadora. 
Suspeitamos que Ester, foi filha única, pois os registros e os relatos analisados não emitem nenhuma referência a respeito da existência de irmãos, apenas a presença dos pais, de primos e tios; fato que nos leva a suspeitar de que Ester Nunes Bibas recebeu todo o apoio necessário familiar para que viesse a ter uma formação escolar diferenciada que lhe abriu os caminhos para o letramento e para a escrita qualificada. Habilidades inclusive que tende a justificar a inscrição de Ester Nunes Bibas aos 14 anos na Sociedade Beneficente 15 de Agosto, que reunia desde o século XIX grandes escritores vigienses e paraenses em diferentes áreas do saber, embora sob a marca predominante da escrita literária.

Assim, no seio familiar, Ester Nunes Bibas, recebeu além do apoio, experimentou vivências e experiências que desde cedo foram qualificando a escrita da menina Ester, principalmente no campo da literatura. Outro fator imprescindível, segundo Woolf (1929) para a mulher se firmar no campo intelectual e outros campos; a primeira coisa que deve ter é independência econômica, porque sem ela, sempre estará sendo descriminada através da subordinação social e intelectual. O que parece que este suporte foi garantido à Ester Nunes Bibas no período de formação.

O empreendimento da escrita literária, seguida pela escrita pedagógica de Ester Nunes Bibas, embora contanto com apoio familiar, acreditamos que esta escritora se deparou com algumas situações limites. O que nos leva a problematizar como uma mulher paraense originária da cidade de Vigia viesse a galgar o posto de escritora e intelectual do campo da educação; considerando-se a ordenação social, política e cultural local como limitante aos avanços da atuação feminino no campo da escrita e da intelectualidade. Ester Nunes Bibas ao chegar à cidade de Belém para dar continuidade a seus estudos, se depara com um "epicentro" cultural belenense que referendava a cultura letrada masculina e que em tempos de belle époque, essa elite intelectual masculina ganhou maior visibilidade por interferir na proposição dos processos civilizatórios para o espaço social da cidade de Belém, como também para o campo escolar. Como afirma Corrêa (2015, P. 32,33), nesse processo de reordenação social e econômica, a ausência de registros sobre a atuação de mulheres letradas, num momento em que a cidade de Belém do Pará experimentava tempos de dinamismo social e cultural, assim a ausência desses registros sobre as escrituras femininas levou a entender que nessa realidade social a permanência dos condicionamentos impostos à participação feminina e contribuiu para a contínua ocultação e silenciamento das mulheres paraenses. Em meio aos discursos de modernização e do reconhecimento da formação dos sujeitos, a urbe belenense se moderniza, mas manteve-se como território de desigualdade, na medida em que, os ideários de modernidade referendavam os privilégios dos grupos majoritários nas diferentes áreas da 
sociedade local e desta maneira não promoveu a autonomia do sujeito feminino.

Em Belém, Ester Nunes Bibas se aliou a grupos de mulheres intelectuais de diferentes campos de atuação, ao se associar ao Núcleo paraense do Progresso Paraense, que reunia mulheres da classe média, mulheres letradas como poetisas, professoras, jornalistas, musicistas e militantes em defesa do voto da mulher. São mulheres que escreviam na imprensa local, ou seja, são mulheres que ocupavam um lugar diferenciado na sociedade paraense. Acreditamos que esse grupo de mulheres paraenses neste movimento, já demonstravam certo empoderamento e visibilidade para falarem de um lugar comum e nessa associação se fortalecem em defesa do voto feminino. São mulheres que ocupam um lugar distinto no espaço público em defesa de uma causa feminina.

São mulheres que independente do lugar que falam, apresentam vinculações sociais e políticas bem definidas. Algumas mulheres associadas ao Núcleo Paraense apresentavam vinculações com a revolução de 1930, e se tornaram apoiadoras do governo do Intendente Magalhaes Barata; o que demonstra a vinculação política à direita de Ester Nunes Bibas e de suas companheiras nesse movimento político, que marcará a Segunda República Brasileira, notadamente marcada pela ascensão dos ideários nacionalista e do desenvolvimentismo, pela emergência do industrialismo versus trabalhismo populista.

Outro aspecto que sinaliza o protagonismo de Ester Nunes Bibas é marcado pelo contato direto que mantinha com outras professores do seu tempo, como Hilda Vieira, Poranga Jucá, Palmira Gabriel, Palmira Lins de Carvalho, entre outras professoras, que além da amizade do campo profissional, acreditamos que trocavam ideias, experiências e ponto de vistas com relação a educação do estado do Pará. Acreditamos também pelos relatos, que Ester Nunes Bibas estabelecia a política da boa vizinhança, uma mulher de diálogo e atuava junto à rede de amizades para a concretização de seus propósitos. Com relação editoração de sua produção didática estabeleceu uma negociação pessoal ao se aproximar do representante da Editora do Brasil S.A, em Belém, para o qual, fez apresentação de seus manuscritos de seus livros, tendo seu trabalho sido aprovado pela intermediação desse representante. Sua coletânea Páginas Brasileiras foi impressa e passou a fazer parte da Coleção Didática do Brasil, Série Primária, Vol. 19. Editora do Brasil S.A. Acreditamos que a coletânea de Ester Nunes Bibas, apresentava objetivos que se coadunavam a proposta editorial desta grande editora nacional de livros didáticos, sob o enfoque moral e cívico.

A terceira pontuação se refere à autora e seu pensamento educacional construído a partir da interferência de vertentes ou tendências educacionais apreendidas ou associadas pela professora Ester Nunes Bibas, que de maneira transversal perpassam por sua proposição 
didático-pedagógica.

No transitar pela Primeira e Segunda República, tempos históricos sinalizados pelos livros didáticos Páginas Brasileiras e seguindo as observações dos relatos de Vânia Bibas e Jaime Bibas (2015, 2016), apreendemos que a coletânea de livros didáticos Páginas Brasileiras foi um empreendimento construído unicamente por Ester Nunes Bibas e sua produção se deu ao longo de suas experiências como educadora do ensino primário, o que nos levou a compreender a recorrência dos discursos pedagógicos enunciados por estes livros didáticos apresentarem-se atrelados aos ideários políticos-ideológicos dominantes deste período da história republicana brasileira. Como escritora local-regional, Ester Nunes Bibas transitou por entre vertentes do liberalismo conservador, que por décadas, demarcou a escola tradicional, assim como conviveu com as inovações propostas por educadores que apostavam na modernização da escola e dos processos educacionais, a partir da concepção da Escola Nova. Nesta longa trajetória como educadora, a autora caminhou entre diferentes pensamentos e vertentes sobre a educação, sobre a escola, sobre o processo de formação escolar, sob a tônica da defesa de uma educação como salvadora da Pátria e do povo brasileiro cuja finalidade se voltava para a redução do analfabetismo e para preparar crianças e jovens para o trabalho e para o enaltecimento da nação, como condições para a modernidade pela via do desenvolvimento econômico, como sinônimo de industrialização do país.

Os textos analisados do terceiro e do quinto livro de Páginas brasileiras, demonstram uma estreita relação com pensadores liberais, católicos, humanistas, enquanto autores que falam e escrevem de diferentes lugares: da política, do direito, do jornalismo, da educação, da literatura de diferentes escolas, da linguagem, da gramatica e autores regionalistas. Autores, que com seus escritos defendem bandeiras político-ideológicas e uma educação moral, cívica e patriótica. São discursos que embasam o pensamento educacional de Ester Nunes Bibas, oriundos da elite pensante do país, predominantemente formado por homens intelectuais, homens de letras e de outro saberes. Homens em sua maioria com reconhecimento nacional, regional-local e que dentre esses, o número significativo de acadêmicos da Academia Brasileira de Letras - ABL, e que se apresentam como homens nascidos no século dezenove e atuantes escritores no decorrer do século vinte. Um dado que revela uma proximidade à própria trajetória de Ester Nunes Bibas e por se constituírem em sua maioria como literatos de diferentes vertentes, positivistas parnasianos, republicanos, modernistas, humanistas entre outros. Ester Nunes Bibas no terceiros livro, assim como os demais autores selecionados pela autora, através de seus textos trazem contribuições para processo da leitura e da escrita escolar, com deferentes tipos de gêneros textuais, como a prosa, a poesia, textos narrativos, 
textos descritivos, orações, fábulas e textos sobre a realidade regional.

A Quarta Pontuação refere-se à bandeira de luta de Ester Nunes Bibas pela defesa da cultura amazônica e paraense. Em sua coletânea enfatiza essa preocupação, como professora escritora empenhada com a educação paraense. Na verdade, Ester Nunes Bibas levantou uma questão sobre a educação do Pará, ao questionar os livros que vinham de fora e adotados nas escolas públicas paraenses. Sua maior preocupação estava relacionada à defesa da cultura do Estado, pois os livros que vinham de fora, quase sempre do sudeste brasileiro. Tratavam de lendas, estórias e paisagens de outros lugares, o que dificultava a compreensão da cultura local pela incorporação de uma realidade e de uma cultura distanciada do cotidiano dos alunos Essa defesa pela cultua amazônica e paraense teria sido a razão maior que levou a professora Ester Nunes Bibas a escrever sua coletânea didática Páginas Brasileiras. A regionalidade como aspecto bem destacado no terceiro livro e como afirmou Vania Bibas em seus relatos, aspectos bem demarcados também no primeiro e no segundo livro, infelizmente não localizados. Baseando-se nos comentários de Jaime Bibas (2017), ao adentrar no sistema de ensino público, e a partir de suas experiências como educadora, começou a organizar conteúdos e temas, que visibilizasse o estado do Pará, a cidade de Belém e a cultura nortista. Conteúdos que foram inseridos em sua obra para suprir a ausência dessa temática nos livros então adotados. Conteúdos retratados em seus textos como: Belezas do Rio-Mar, Sou Paraense, Um passeio, Capital Guajarina, Belém do Pará, entre outros textos, que enfatizavam os aspectos geográficos, ambientais, flora e fauna regional. Compreendemos que o víeis regionalista se constituiu a grande contribuição trazida por esta produção didática e Ester Nunes Bibas, colocou em prática seus anseios e consegue trazer textos sobre a cultura, a história, as vivências e a geografia local.

Nessa apreensão, definimos Ester Nunes Bibas, como uma mulher singular e plural, que se movimentou pelo espaço privado, como mãe de família, esposa e educadora dos filhos e netos e pelo espaço público, a partir da produção publicação de textos literários, pelos caminhos da educação como professora, orientadora educacional e escritora de livros didáticos para o ensino primário. Uma circulação e uma atuação, que define Ester Nunes Bibas, como poetisa, professora, escritora e intelectual do campo da educação, como identidades plurais que vão sendo construída por esta mulher que transitou dos fins do século XIX e ao longo de sua trajetória pelo século XX, ao produzir experiências, vivências e uma produção cultural, a partir de seus escritos e escritos publicados em livros didáticos e ou em textos literários.

O pensamento didático-pedagógico enunciado possibilitou a compreensão de que as 
professoras normalistas se constituem no seu fazer profissional sujeitos epistêmicos e produtores do saber escolar. Saberes que vão sendo apreendidos, mobilizados e produzidos a partir da formação pedagógica e na experiência em sala de aula. Neste processo, os saberes docentes estando diretamente vinculados ao contexto social, aos acontecimentos na vida pessoal, na vida profissional numa produção que se constrói na interface das dimensões individuais e profissionais mediadas pelo contexto sociocultural em que esses sujeitos encontram-se inseridos.

A coletânea didática Páginas Brasileiras, tornou-se uma escrita pedagógica para o ensino primário do estado do Pará, que caminhou de forma marginal, pelo fato de não ter recebido o referendo oficial da Secretaria de Estado de Educação- SEDUC-PA, como livros didáticos para serem adotados pelas escolas. No entanto, adentraram nas escolas públicas e circularam por vários anos ensinando crianças e adolescentes do ensino primário, o que justifica 07 reedições desta produção local. Uma conquista associada à atuação da editora do Brasil S.A no estado do Pará e ao espírito de luta desta autora para o alcance de seus ideais, traduzidos nos versos "Eu sempre fui rebelde! A rebeldia transborda no meu sangue e, dominante, torna-se forte e forte contagia a perseguir na luta, - triunfante! [...] opiniões contrárias não aceito! (BIBAS, 1958, p.29). Palavras que emanam da subjetividade e da vontade, que lhe revestiu de resistência para ir além das barreiras enfrentadas, no caminhar c pelo espaço fronteiriço, de maneira estratégica e persistência para enfrentar as adversidades postas às escrituras femininas.

Características subjetivas que aliadas aos fatores sociais, econômicos e a formação qualificada tornaram-se fatores impulsionadores para que essa professora paraense viesse a se tornar uma mulher com "voz" e com uma escrita impressa, embora, tenha recebido reconhecimento oficial institucionalizado nos anos finais de sua carreira como educadora e ou após sua aposentadoria, quando então, é homenageada como professora do ano em 1958, pela Sociedade Paraense de Educação, agraciada com a medalha do Centenário de Paulino de Brito, em 1960 recebeu a medalha de honra ao mérito outorgado pela Câmara Municipal de Belém, e o reconhecimento, que ganha os noticiários na imprensa local, quando sua coletânea didática é traduzida para o Braile, para o ensino dos alunos da Escola Álvares de Azevedo. Momento de reconhecimento intelectual da autora e sua obra didática ainda que tardiamente, como professora e autora do campo educacional paraense.

Destarte, consideramos que a presente tese alcançou sua intencionalidade investigativa, na medida em que, rompeu com o silêncio e a ocultação desta autora paraense e sua produção didático-pedagógica, e abriu caminho para a retomada de novos estudos acerca 
da mulher professora e escritora da educação paraense no circuito do debate e da pesquisa acadêmica. 


\section{REFERÊNCIAS}

ALCÂNTARA, Wiara Rosa Rios. "Mensageira de Relações": A Professora Primária como Intelectual da cidade, Revista Fac. Educ. Universidade do Estado de Mato grosso, vol. 19, ano 11, p. 71-92, 2013.

ALMEIDA, Jane Soares de. Mudaram os Tempos, Mudaram as Mulheres, Revista de Avaliação de Educação Superior, Campinas, São Paulo, 2012.

Mulher e Educação: a paixão pelo possível, São Paulo, Editora UNESP, 1998.

ALAMBERT, Zuleika. Mulher Uma Trajetória Épica. São Paulo, Imprensa Oficial de São Paulo S.A, 1997.

A Mulher na História, Brasília, Fundação Astrojildo Pereira, 2004.

ÁLVARES, Luzia Miranda. Mulheres e Participação Política, GEPEM/UFPA, Instituto de Filosofia e Ciências Humana, 2011.

Saias, Laços \& Ligas. Construindo Imagens e Lutas (Um Estudo sobre as Formas de Participação Política e Partidária das Mulheres Paraenses- 1910-1937), Dissertação, NAEAUFPA, 1990.

ALVES, Claudia, Ana Chrystina Mignot. História e Historiografia de Educação IberoAmericana: Projetos, Sujeitos e Práticas, Rio de Janeiro: Quartet - Faperj - SBHE, 2012.

ALVES, Maria Angélica. A Educação feminina no Brasil do Entre-Séculos ( XIX e XX) Imagens da Mulher intelectual, II Congresso Brasileiro de História da Educação, 2002.

ÁVILA, Rebeca Contrera. Minha História das Mulheres. Michelle Perrot. Revista Social $n^{\circ}$ $16,2009$.

ARAÚJO, Joseane Souza. Arquivos, Bibliotecas e Periódicos na Vigia Oitocentista, Universidade Federal do Pará, Programa de Pós-Graduação em Estudos literários, Dissertação, Belém-Pará, 2011.

ARAÚJO, Marta Maria. Plasticidade do Plano de Reconstrução Educacional de ANÍSIO TEIXEIRA (1952-1964), Revista educativa, Goiânia, v. 10, n. 1, p. 9-27. 2007.

ARROYO, Miguel. Outros Sujeitos. Outras Pedagogias, Editora Vozes, 2014.

BACELAR, Bruna Valença. A Mulher Subalterna em "Pode o Subalterno falar", de Gayatri Spivak, NEARI em Revista, vol. 2, nº. 2, 2016.

BARROS, José D’Assunção. A Nova História Cultural- Considerações sobre seu universo e seus diálogos com outros campos históricos, Cadernos de História, Belo Horizonte, v.12, 2011. 
Considerações sobre o Paradigma Positivista em História, Revista Historiar Universidade Estadual Vale do Acaraú, v. 4, nº. 4, Sobral - CE, 2010.

O Campo da História - A Partilha do Saber Histórico na Historiografia Contemporânea, ANPUH - XXIII Simpósio Nacional de História, Londrina, 2005.

Os Campos da História - Uma Introdução as especialidades e abordagens, Petrópolis; Vozes, 2004.

História Cultural: Um Panorama Teórico e Historiográficos, Revista Textos de História, v.11, 2003.

BAKHTIN, Mikail. Maxismo e Filosofia da Linguagem. São Paulo, Editora Hucitec, 2009.

BARROS, José D'Assunção. Os Campos da História - Uma Introdução as especialidades e abordagens, Petrópolis; Vozes, 2004.

Estética da Criação Verbal, tradução feita por Maria Emsantina Galvão G. Pereira, revisão Marina Appenzellerl, 2ª Edição, São Paulo, Martins Fontes, 1997.

BARTHES, Roland. O Rumor da Língua, tradução de Mário Laranjeiras, Editora Martins Fontes, São Paulo, 2012.

BARTHES, Roland. O Prazer do Texto, tradução de J. Guinsburg, São Paulo-SP, Editora Perspectiva, 1987.

BARTHES, Roland. Escritores, Intelectuais, Professores, Lisboa, Presença, p. 25-61, 1975.

BASTOS, Maria Helena Camara. História e Memórias da Educação no Brasil, Vol. III século XX, Editora Vozes, 2005.

BERNARDES, Maria Thereza Caiuby Crescenti. Mulheres de Ontem?: Rio de Janeiro, século XIX, São Paulo, T.A. Queiroz, 1988.

BHABHA, Homi. O Local da Cultura, tradução de Myriam Ávila, Eliana Lourenço de Lima reis, Gláucia Renate Gonçalves, 2.ed. Belo Horizonte, Editora UFMF, 2013.

BIBAS, Ester Nunes. Páginas Brasileiras, Terceiro Livro, Coleção Didática do Brasil, Série Primária, vol. 19, São Paulo, Editora do Brasil, 1967.

Rimas do Coração, poesias, H. Barra, Belém- Pará, 1958.

Páginas Brasileiras, Quinto Livro, Coleção Didática do Brasil, Série Primária, Vol. 21, São Paulo, Editora do Brasil S.S, 1957.

BITTENCOURT, Circe M. F. (1992) Livro Didático e Conhecimento Histórico (Tese de Doutorado). São Paulo. FAE/USP. 1993. 
Pátria, Civilização e Trabalho: O Ensino de História nas Escolas Paulistas (19171939). São Paulo. Loyola. 1990. BITTENCOURT, Circe M. F. (1992) Livro Didático e Conhecimento Histórico (Tese de Doutorado). São Paulo. FAE/USP. 1993.

BRAGHINS, Katie Mytsuko Zuquin. A Editora do Brasil S.A anos 1960-1970, Revista Brasileira de Educação, v. 12, p. 153-178, 2012.

BHABHA, Homi. O Local da Cultura, 2a edição, Belo Horizonte, Editora UFMG, 2013.

BRAIT, Beth, BAKHTIN Outros Conceitos- Chave, (org), $2^{\mathrm{a}}$ edição, São Paulo, Contexto, 2014.

BAKHTIN Conceitos-Chave, (org), 5a edição, São Paulo, Contexto, 2013.

BRANDÃO, Antônia Mariza Rodrigues. Leitura e Literatura na Escola, Revista Kaliope, São Paulo, ano 3, nº 2, p. 26-47, 2007.

BRANDÃO, Ruth Silviano. Mulher ao Pé da Letra, Belo Horizonte, Editora UMG, 2006. lira de História de Educação, Campinas -SP, vol. 12, nº 3, p. 153-178, 2012.

BRUILlE, Celma Faria de Souza. A Trajetória da Mulher na História do Brasil: Submissas ou Ardilosas.(sem notificação de ano e revista de publicação).

BURKE, Peter. A Escola dos Annales, 1929-1989, Editora UNESP, 2010. $\overline{\text { Janeiro, }} 2008$.

O que é História Cultural?, tradução Sérgio Goes de Paula, 2a Edição, Rio de A Escrita da História Novas Perspectivas, São Paulo, Editora UNESP, 1999.

CAMBI, Franco. História da Pedagogia. 1 Reimpressão. Tradução de Álvaro Lorencini. São Paulo: Editora UNESP, 1999.

CAMPOS, Maria Inês Batista. A Questão da arquitetônica em Bakhtin: um olhar para materiais didáticos de língua portuguesa. Revista Filol. Linguist. Port., n. 14, p. 247-263, 2012.

CARDOSO, Mayra Paniago Spínola. De Normalista a Professora, Dissertação, Universidade Estadual de Feira de Santana, programa de Pós-Graduação em História, 2011

CARDOSO, Wanessa Carla Rodrigues. A Literatura Cívica Patriótica: República, Educação e Manuais Didáticos no Pará Republicano (1900-1920), XXVIII SIMPOSIO NACIONAL DE HISTÓRIA, Florianópolis-SC, 2015.

CARVALHO, Marta Chagas. Modernidade Pedagógica e Modelos de Formação Docente, São Paulo, PERSPEC. VOL. 14, 2000.

CASTANHO, Sérgio. Teoria da História e História da Educação, Campinas, Editora Autores Associados LTDA, 2010. 
CATANI, D. B. et al. (Org.). Docência, memória e gênero: estudos sobre formação. São Paulo: Escritura Editora, 1997.

CATHARINO, Adriana Lemes. O descritivo no Ensino: Limites e Possibilidades. Dissertação de Mestrado em Língua portuguesa, Pontifícia Universidade Católica de são Paulo - PUC - SP., 2007.

CERTEAU, Michel. A Escrita da História; tradução de Maria de Lourdes Menezes, Rio de Janeiro: Forense Universidade. 1982.

A Invenção do Cotidiano: A Arte de Faze, Petrópolis: Vozes, 1994.

A cultura do plural. Campinas: Papirus, 1995. (Coleção Travessia do Século)

CHARTIER, Roger. A História ou a leitura do tempo; tradução de Cristina Antunes - 2. Ed.; 1. Reimp. - Belo Horizonte: Autêntica Editora, 2015.

A Mão do autor e a mente do editor, tradução George Schlesinger - 1. Ed - São Paulo; Editora Unesp, 2014.

A História Cultural Entre Práticas e Representações, Memória e Sociedade, $2^{\mathrm{a}}$ edição, DIFEL, 2002.

A Aventura do Livro: do leitor ao navegador, Editora UNESP, 1988.

CHOPPIN, Alain. História dos Livros e das edições didáticas: Sobre o estado da arte. Revista Educação e Pesquisa, São Paulo, v. 30, n. 3, p. 549-560, 2004.

Pelotas, 2002.

O Historiador e o livro escolar - História da Educação. ASPHE/ FAE/ UFPEL,

COELHO, Geraldo Mártires. Na Belém da Expansão da Borracha (1890-1910): Dirigindo olhares, Revista da Casa de Rui Barbosa, ano 5, nº. 5, 2011.

COELHO, Maricilde Oliveira. A Escola Primária no Estado do Pará (1920-1940), Tese, Programa de Pós-Graduação em Educação, Faculdade de Educação, Universidade de São

CORDEIRO, Paula Maíra Alves. Memórias Despetaladas no Jardim da Poesia: Uma análise dos Poemas de Ester Nunes Bibas na Obra Rimas do Coração, TCC apresentado a Universidade do Estado do Pará, Curso de licenciatura Plena em Língua Portuguesa, VigiaPará, 2016.

CORREA, Ana Maria Maciel. Família e Compadrio: O Estabelecimento de relações Sociais protetivas e Assistencialistas em Belém na Belle Époque. Comunicação Oral no VII Encontro Maranhense de História de Educação, no período de 22 a 25 de abril de 2014 UFMA, São Luís, 2014.

A educação em Tempos Republicanos na Obra de Ester Nunes Bibas, comunicação oral no VIII Encontro Maranhense de História de Educação no período de 12 a 15 de maio de 2015, UFMA, São Luís, 2015. 
CORRÊA, Rosa Lydia Teixeira. A Educação Escolar em Perspectiva. Campinas/SP: Autores Associados; Rio de Janeiro: SBHE. p. 171-225, 2005.

O livro escolar como fonte de pesquisa em História da Educação, Cadernos Cedes, ano XX, n. 52, novembro/ 2000.

COSTA, Marta Morais. A Constituição da Escola da Leitura da Literatura, Seminário internacional de representações Sociais, Subjetividades e educação; Seminário Internacional sobre Prosissionalização Docente, XIII Congresso Nacional de Educação, EDUCERE, 2008.

COSTA, Rafaela Paiva. A Formação de Professores da Primeira república no Pará (19001904), UFPA, Dissertação apresentada ao Programa de Pós-Graduação de Educação, 2011.

DELL"ISOLA, Regina Lúcia Pèret (Org.). Gêneros Textuais. O que há por trás do Espelho?/ Belo Horizonte, FALLE/UFMG,. 2012.

DAMASCENO, Alberto. A Planificação da Educação dos Anos 30 a 60: Pioneirismo, Reformas, Submissão e Tecnocracia, Revista HISTDBR On-line, Campinas, $n^{\circ} .68$, p. 125 137, 2016.

Sobre a Educação Paraense na Segunda República, Revista HISTDBR On-line, Campinas, $\mathrm{n}^{\circ} .67$, p. 229-241, 2015.

DARNTON, Robert. O que é a história do livro, tradução Lilia Gonçalves Magalhâes Tavoraro, Revista ArtCultura, Uberlândia, V. 10, nº. 16, p. 155-169, 2008.

DEL Priore, Mary. História das Mulheres, in Historiografia Brasileira em Perspectiva, Marcos Cezar de Freitas (org.), 7ª Ed, São Paulo, Contexto, p. 217-236, 2012.

Mary. História das Mulheres no Brasil, 2ª edição, São Paulo, Contexto, 1997.

FARACO, Carlos Alberto. Aspectos do Pensamento estético de Bakhtin e seus Pares, Revista Letras de Hoje, Porto Alegre -RS, v.46, nº.1, p. 21-26, 2011.

FARIAS, Sandra Aparecida Lima Silveira. Gêneros Textuais em Livros Didáticos; Uma Análise de Duas Coleções do Ensino Médio; UFB, Programa de Pós-Graduação em Língua e Cultura, Dissertação, 2013.

FERNANDES, Débora Araújo. Os Manuais de "História Pátria Regional" E As representações do Ensino de História do Pará no início do Século XX (1902-1926), Dissertação apresentada ao Programa de Pós-Graduação em Ensino de História, Universidade Federal de Tocantins, Araguaína - TO, 2016.

FERRAROTTI, Franco. Sobre a Autonomia do método biográfico, Revista SociologiaProblemas e Práticas, nº 1991, p. 171-177, 2001.

FERRAZ, Cláudio Benito O. Entre-Lugar: Apresentação. Revista Entre-Lugar, Dourados, MS. Ano 1, n. 1, Universidade Federal da Grande Dourados, 2010. 
FERREIRA, Márcia dos Santos. Centro de Pesquisa do INEP: pesquisa e política educacional entre as décadas de 1950 e 1970, Tese apresentada à Faculdade de educação da Universidade de São Paulo, 2006.

FERNANDES, Maria Lúcia Outeiro. O texto literário no Livro Didático, Revista Itinerários, Araraquara, vol. 17, p. 165-177, 2001.

FIGARO. Roseli. Comunicação e Análise do Discurso (org.), São Paulo, Editora contexto, 2015.

FILGUEIRAS, Juliana Miranda. A Campanha do Livro Didático e Manuais de Ensino, XXVI Simpósio Nacional de História, São Paulo, 2011.

FIORIN, José Luiz. Tendências da Análise do Discurso, Caderno de Estudos linguísticos, v. 19, p. 173-179, 1990.

FRAZÃO, Erika Elizabeth Vieira, RALEJO, Adriana Soares, Narrativas do "outro" nos livros didáticos de História, anais - XV Encontro Regional de História da ANPUH-Rio, 2012.

FREITAS, Ana Maria Gonçalves de; Motta, Diomar (org). Mulheres na História da Educação: direitos, conquistas e resistências, São Luís, EDUFA UFMA, 2011.

FREITAS, Marcos Cezar de. Historiografia Brasileira em Perspectiva (org), $7^{\text {a }}$ ed, São Paulo, contexto, 2012.

FREIRE. Eleta de Carvalho. Mulher no Magistério: Uma História de embates entre espaço público e espaço privado, Revista lugares de Educação, Bananeiras, PB, 2011.

GASPARELLO. Arlete Medeiros. Intelectuais e Professores, Revista Brasileira de História de Educação, 2009.

GATTI JR., Décio (2004a). A escrita escolar da História: livro didático e ensino no Brasil (1970-1990). Bauru/SP:Edusc, Uberlândia/MG, Edufu, 2004

História da Educação: consolidação da pesquisa nacional e ampliação dos espaços de divulgação científica. Educação e Filosofia v. 18. Número especial, p. 05-22, 2004b.

GATTI JR. Décio. Entre Políticas de Estado e Práticas Escolares: Uma História do Livro didático no Brasil, in História e memórias da educação no Brasil, Vol. III, Petrópolis, Editora Vozes,p.379-400, 2012.

GERALDI, João Wanderley. Bakhtin tudo ou nada diz aos educadores: Os educadores podem dizer muito com Bakhtin. In Educação, Arte e Vida em Bakhtin, Maria Tereza Assunção Freitas (org.), Belo Horizonte, Autêntica, 2013.

GIROUX. Henry. Os Professores como intelectuais, Porto Alegre, Editora Artes Médicas, 1997. 
GUERRIERI, Zuleika Anália de Almeida. História do Ceará: O regionalismo presente na produção didática nos anos 1930 e 1960, XXVII Simpósio Nacional de História, Natal RN, 2013.

HAJE, Fernando. Olhares e Imagens da Mulher Paraense Atravessando a cidade entre os séculos XIX e XX, VIII Colóquio de Moda, Congresso Internacional da Moda, Rio de Janeiro, 2012.

HALLEWEL, Laurence. O Livro no Brasil - Sua História, São Paulo, $2^{a}$ ed, Editora da Universidade de São Paulo, 2005.

HOMEM. Maria Lúcia. No limiar do Silêncio e da Letra, São Paulo, Bomtempo: EDUSP, 2012.

LEAL, Mayara Mendes. Da missa à eleição: A Política do Padre José Maria do Lago na década de 1930; Revista Estudos Amazônicos, Vol. XI, nº 2, p. 46-78, 2014.

LIMA. Élcio Gomes. Para Compreender o Livro Didático como Objeto de Pesquisa, revista Educação e Fronteira, On-line, Dourados, 2012.

LOPES, Silvana Fernandes. "Retratos" de Mulheres na Literatura Brasileira Do Século Xix, Revista Plures Humanidades, Ribeirão Preto, ano 12, nº 5, p. 117-140, 2011.

LOURO, Guacira Lopes. Gênero, Sexualidade e Educação. Uma Perspectiva Pósestruturalista, Editora Vozes, 2013.

LUCENA. Paola Lili. Rompendo Silêncios e descobrindo mulheres: Uma Análise da Obra de Michelle Perrot no contexto da história das mulheres. $2^{\circ}$ Seminário Nacional de História da Historiografia, Ouro Preto, EDUFOP, 2008.

MACHADO, Bárbara Araújo. A Função do Intelectual: Um diálogo entre Antônio Gramsci, Pierre Bourdieu e Edward Said, Revista Teoria da História, Revista da Faculdade de História e do Programa de Pós-Graduação em História da Universidade Federal de Goiás.

MACHADO, Maria Cristina Gomes. SOCIEDADE, ESTADO E EDUCAÇÃO: As várias facetas de Rui Barbosa, Revista HISTEDBR On-line, Campinas, n.41, p. 32-60, mar2011 ISSN: 1676-2584.

MAFRA, Alessandra R ES; Vida Cultural, Intelectualidade na Belém dos meados de 1950, XXXVIII Simpósio Nacional de História, Florianópolis - SC, 2015.

MAIOLINI, Iara Lopes. Uma Proposta Enunciativo-Discursiva de Leitura de Contos para o Ensino Fundamental, Dissertação, Universidade Federal do Mato grosso, Instituto da linguagem, Programa de Pós-Graduação em Estudos da linguagem, Cuiabá-MT, 2013.

MARCUSCHI, Luiz Antônio. Linguística de Texto: O que é e como se Faz? - São Paulo, Parábola Editorial, 2012. 
MARTINS JÚNIOR, Rui Jorge Moraes. Visto, logo Existo: Moda, sociabilidade feminina e consumo em Belém no limiar do século XX, Dissertação apresentada no Programa de PósGraduação em História Social da Amazônia, Universidade Federal do Pará, 2010.

MATTOS, Selma Rinaldi. Estado, Nação e Etnia na Construção do Estado Imperial através do Compêndio de História do Brasil de José Inácio de Abreu e Lima. II CONGRESSO BRASILEIRO DE HISTÓRIA DA EDUCAÇÃO, 2002.

A História do Ensino de História do Brasil através dos Manuais Didáticos de

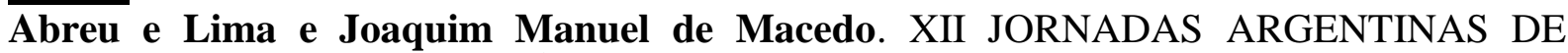
HISTORIA DE LA EDUCACIÓN. Anais. CD-ROM. 2001.

O Brasil em Lições: a história como disciplina escolar em Joaquim Manuel de Macedo. (Coleção Aprendizado do Brasil), Rio de Janeiro, Access Editora, 2000.

MEIRA, Clóvis. A Lira na Minha Terra, Belém, editora Cejup, 1996.

MELO, Clarice Nascimento de. SENDAS DA ESCOLARIZAÇÃO FEMININA NO PARÁ, Revista HISTEDBR On-line, Campinas, número especial, p. 83-102, out2011 - ISSN: 1676-2584

MENDES, Mayara Silva. Conflitos Religiosos e Relações Políticas no Pará 9 1930-1941, Dissertação apresentada na universidade Católica de São Paulo, Programa de Estudos PósGraduados em História, 2006.

MENDONÇA, Ana Waleska, XAVIER, Libânia Nacif. Por uma Formação do Magistério Nacional: O Inep/MEC dos anos 1950-1960.

MIGUEL, Maria Elisabeth Blanck. A PRESENÇA DAS TENDÊNCIAS PEDAGÓGICAS

NA EDUCAÇÃO BRASILEIRA, educativa, Goiânia, v. 10, n. 1, p. 69-84, jan./jun. 2007.

MORAES, Felipe Tavares de; COSTA, Rafaela Paiva. Educação como Sacerdócio: Formação de Professores no Pará Republicano (1891-1904), Revista Brasileira de História da Educação, Maringá, V. 14, nº. 3, p. 123-150, 2014.

MORAES, Jair Santana. O Inep na visão de seus pesquisadores, Inep, MEC, Brasília - DF, 2008.

MOREIRA, Eidorfe, Obras Reunidas, vol. VI, Belém: CEJUP, 1979.

MOTTA, Diomar das Graças. Intelectuais e Construção Histórica do Debate Educacional: a perspectiva do sujeito mulher professora; Revista cad. Pes., São Luís, v. 23, n. Especial, set./dez. 2016.

MUNAKATA, Kazumi. Produzindo Livros Didáticos e Paradidáticos, Tese apresentada à Pontifícia Católica de São Paulo - PUC-SP, 1997.

NARVAZ, Martha Giudice, KOLLER, Sílvia Helena. Família e Patriarcado: da prescrição à submissão criativa. Revista Psicologia \&Sociedade, Porto Alegre, 2006. 
NOVAIS, Fernando A, SILVA, Rogério F. Nova História em perspectiva, São Paulo, Cosac Naify, 2011.

NÓVOA, Antônio. Vida de Professores (0rg), Porto editora, Porto-Portugal, 2013.

ORLANDI, Eni, LAGAZZI-RODRIGUES. Introdução às Ciências da linguagem Discurso e Textualidade, Campinas, SP, $3^{\text {a }}$ Edição, Pontes Editores, 2015.

Discurso e Leitura, 9a edição, São Paulo, Cortez, 2012.

As Formas do Silêncio: no movimento dos sentidos, $6^{a}$ edição, Campinas, SP, Editora Unicamp, 2007.

PALMA FILHO, João Cardoso. Educação Brasileira no período de 1930 a 1960 Pedagogia Cidadã. Cadernos de Formação. História da Educação, 3 ed. São Paulo. Programa /UNESP - Santa Clara Editora, 2005, P. 61-74.

PERROT, Michelle. As Mulheres ou os silêncios da História, tradução Viviane Ribeiro, Bauru, SP, EDUSC, 2005.

Os Excluídos da História - História e Historiografia, tradução de Denise Bottmann,

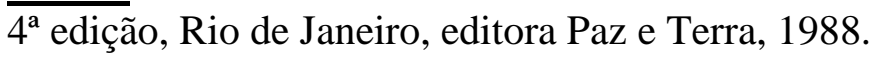

PINSKY, Carla Bassanezi, PEDRO, Joana Maria. Nova História das Mulheres no Brasil, $1^{\text {a }}$ ed. São Paulo, Contexto, 2013.

POZO, Juan Ignácio, Aprendizes e Mestres: a nova cultura da aprendizagem. Porto Alegre: Artmed Editora.2002.

PUCCI, Renata. Questões de Alteridade e Identidade. Revista Impulso, Piracicaba, p. 4349, 2011. ISSN Impresso 0103-7676.

RABELO, Amanda Oliveira. A Mulher no Magistério Brasileiro: Um Histórico sobre a feminização do Magistério. VI Congresso Luso-Brasileiro, Universidade de Urbelância-MG, 2006.

REAL, Edson Alexandre Santos. O Nacionalismo na Educação brasileira: a construção de uma Pátria (1830 - 2009) Revista Temporalidades, 2013.

RIBEIRO, Darcy. O Povo Brasileiro: a formação e o sentido do Brasil, São Paulo, Editora Companhia das Letras, 1995.

ROCHA, João Cezar de Castro. Roger Chartier - A Força das representações: história e ficção (org), Chapecó, SC, Argos, 2011.

ROIZ. Diogo da Silva. A Teoria e a Prática dos Intelectuais no Passado e no Presente, Revista Esboços, nº 20, UFSC, 2009.

ROJO, Roxane Rodrigues. Letramentos Escolares: Coletâneas de textos nos livros didáticos de Língua Portuguesa, Revista Perspectiva, Florianópolis - SC, v. 28, nº. 2, p. 
433-465, 2010.

ROSA, Renata Vidica Marques da. Feminização do Magistério: Representações e Espaço Docente. Revista Pandora do Brasil, Edição no 4 - Cultura e Materialidade escolar, 2011.

SAFFIOTI, Heleieth. A Mulher na Sociedade de Classes-Mito e realidade, $3^{a}$ edição, São Paulo, Expressão popular Editora, 2013.

SAID, Edward. Cultura e Imperialismo; tradução Denise Bottmann, São Paulo; Companhia das Letras, 2011.

SANTOS, Ana Christina. Fronteiras da Identidade: O texto híbrido de Gloria Anzaldúa, Revista Interrogação, vol.3, $\mathrm{n}^{\mathbf{0}}$ 1, Revista da Universidade do Estado da Bahia, UNEB, Campos II, Alagoinha - BA, 2013.

SANTOS, Linet de Sá. Mulher Matogrossense na Era Vargas: Educação e Representações, Dissertação apresentada no Programa Pós-Graduação em Educação, Instituto de Educação, Universidade Federal do Matogrosso, 2014.

SANTOS, Sandra Regina Rodrigues dos. História Cultural e História da educação: Um diálogo profícuo, VI Simpósio Nacional de História Cultural, Teresina - PI, UFPI, 2012.

SANTOS, Tatiana Castro dos. Leitura na $4^{\text {a }}$ Série Discursos, práticas e Contribuições para o letramento, Dissertação apresentada ao Programa de Pós-Graduação, Universidade Federal do Acre - Mestrado em Letras: Linguagem e Identidade, 2008.

SAVIANI, Demerval. As Concepções Pedagógicas na História da Educação Brasileira, HISTEDBR, UNICAMP, Campinas, 2005.

.O Debate Teórico no Campo da História e sua importância para o Campo da Pesquisa educacional, In História e História da educação, 2[ edição, Campinas, São Paulo, HISTEDBR, 2000.

SCOTT, Joan W. A invisibilidade da Experiência, Proj. História, São Paulo, 1998.

História das mulheres. In. BURKE, Peter.(Org.) A Escrita da História: Novas Perspectivas. São Paulo: Unesp. 1992.

SILVA, Fidelainy Sousa. A Voz híbrida de Gloria Anzaldúa: do marginal à nova mestiça chicana, revista da Universidade Federal do Rio de Janeiro, 2016.

SILVA, Lucielma Lobato. O ensino religioso nas escolas do ensino modular de Abaetetura-PA: Uma educação científica ou catequética?, X Congresso de Teologia da PUCPR, Curitiba, 2011, Anais.

SILVA, Maria Neide; PAIVA, Marlucia Menezes. O (Não) LUGAR DA HISTÓRIA DA EDUCAÇÃO NA HISTÓRIA: ALGUMAS APROXIMAÇÕES, VI COLUBH, Uberlândia - MG, 2006.

SILVA, Paulo Julião da. A Igreja Católica e a Questão educacional no Brasil durante a Era Vargas, XI Encontro Estadual de História, Universidade do Rio grande, RS, 2012. 
SILVA, Tomaz Tadeu da. Identidade e diferença - A perspectiva dos Estudos Culturais (org), Petrópolis, RJ, Vozes, 2009.

SIRINELLI, Jean - François. Os Intelectuais, in Por uma História Política, RÉMOND, René (org), tradução de Dora Rocha, 2a ed., Rio de Janeiro, Editora FGV, 2003.

SOBRAL, Adail. Do Dialogismo ao Gênero Ás bases do Pensamento do círculo de Bakhtin, Campinas SP, Mercado das Letras, 2009.

SOUZA, Altair. Apontamentos da História do Instituto de Educação do Pará, sem registro de editora, Belém-PA, 1972.

SOUZA, Marcos Aurélio dos Santos. Entre-Lugar e os Estudos Culturais, Revista Travessia, WWW. Unioeste.br, mestrado em letras, sem data de publicação.

SOUZA, Rosa de Fátima. Templos de Civilização: a implantação da escola primária graduada no Estado de São Paulo, UNESP, 1998.

SOUZA, Sônia Ribeiro de. Nação, Nacionalismo e Escola Pública na primeira República. Anais do XXVI Simpósio Nacional de História - ANPUH. São Paulo, julho 2011.

SOUZA, Sweder, SOBRAL, Adail. Gêneros, Entre o Texto e o Discurso, (org), Campinas, SP. Mercado das Letras.

SPIVAK, Gaytry Chacravorty. Pode o Subalterno Falar?, Editora UFMG. Belo Horizonte, 2010.

STEARNS, Peter N. História das Relações de Gêneros, São Paulo, Contexto, 2013.

TAVARES, Hugo Moura. Raymond Williams: Pensador da Cultura, Revista Ágota, Vitória, $\mathrm{n}^{\mathrm{o}} .8$, p. 1-27, 2008).

TAVARES JÚNIOR, Raimundo. Um Viveiro de Mestres: A escola Normal do Pará em Tempos de Modernização (1890-1920), Tese apresentada ao Programa de Pós-Graduação em História da Pontifícia Católica de São Paulo, 2012.

TARDIF, Maurice. Saberes Docentes e Formação Profissional, 16. Ed. Petrópolis, RJ, Vozes, 2014.

TEDESCHI, Losandro Antônio. O Fazer Histórico e a Invisibilidade da Mulher. Revista OPSIS, 2007.

TEIXEIRA, Rosane de Fátima Batista, ROTRS, Geni Alberini. Leitura Literária e livro didático: Uma Parceria Possível? Educere 2008/ Anais.

TRIANA, Cláudia Esperanza Durán. Escrita Feminina e Laços Familiares: Clarice Lispector e Marvel Moreno, Dissertação, Programa de Pós-Graduação em Estudos Comparados de Literatura de Língua portuguesa, Faculdade de Filosofia, Letras e Ciências Humanas da Universidade de São Paulo, São Paulo, 2011. 
VENANCIO, Ana Tereza A. As mulheres pela história: corpo, alma, trabalho e deslocamentos, Fundação Osvaldo Cruz, Vol. 15, 2008.

VEIGA, Cynthia Greive. A Escola da República. Rev. Bras. Hist. Educ., Campinas-SP, v.11, p. 143-178, 2011.

VIDAL, Diana Gonçalves, Carvalho, Marília Pinto, Mulheres e Magistério: Tensões, Ambiguidades e Deslocamentos, In Brasil 500 anos: Tópicas em História da Educação, São Paulo, EDUSP, 2001.

VOESE, Ingo. Análise do Discurso e o Ensino de Língua Portuguesa, São Paulo, Cortez, 2004.

THOMPSON, E. P. A Formação da Classe Operária Inglesa. São Paulo: Paz e Terra, 1987. WILLIAMS, Raymond. Cultura e Sociedade. São Paulo: Editora Nacional, 1969.

XAVIER. A Política de Publicação do CBPE/INEP- Durante a gestão Anísio Teixeira 1952-1964. In O INEP na Visão de seus Pesquisadores, Vol. 3, INEP-MEC, 2008.

ZINANI, Cecil Jeanine Albert.A Literatura e História na

América Latina: Representações de Gênero. Revista METIS: História \& Cultura, v. 5, n. 9, 2006. 
ANEXOS 
Fragmento de Ata do Conselho Estadual de Cultura: Homenagem de Clóvis Meira à profa. Ester Nunes Bibas; em 7/06/1988.

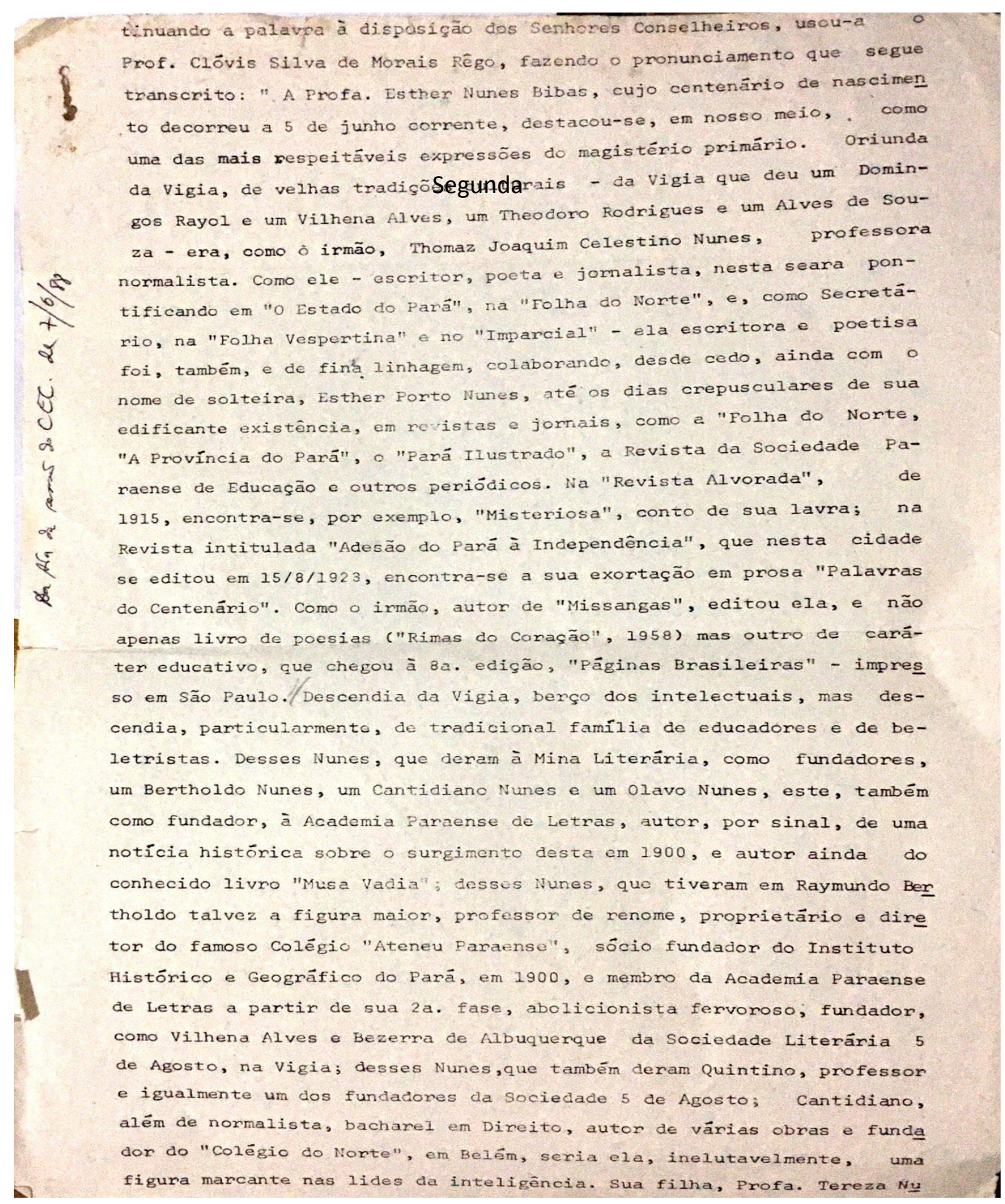


nes Bibas, continua a vocação da família pelo fascínio do apostolado do magistério, mantendo, nesta capital, un dos modelares colégios, entro os que constituem a redo particular de ensino, como continua, como poetisa, a devoção ao bolo, creduzida no poreaverante e torno manejo da 1 ira. Peço, pois, pelo evento on aproģo, a reverênoía deste Egrégio Conselho inserindo on seus Arais, tha sponas o testemunho da sua homenagem, do seu carinho e do sur saudade à grando educadora e poetisa Esther Nunes Bibas, mas tenbéia o artigo que sobre ela escreveu, pelo jornal "O Liberal" de 5/6/88, O Prof. Dr. Clóvis Meira, e, quando voltar à normalidade a ediçäo da Revista ce Cultura do Pará, três poesias da autoria da ilustre homenageada, utra dolas "Angélicas", distribuída por ocasião da celebração da missa do centenário mandada celebrar pela família na Igreja Nossa Senhora de Lourdes, e duas publicadas, igual mente a 5 do mês ca curso, pela "A Província do Parä" -Hora da Prece" (inédita) e "Aquela Lstrela", de tudo se dando notícia aos seus filhos, representados pelos que residem em Belóm, a Major Gratuliano Nunes Bibas e Profa. Tereza Nunes Bibas, cujo enelereģo é: Passagom Ranos, 202." Ainda com a palavra, o Prof. Clóvís Mornis Rếgo comunicou que, en virtude de viagen que deverá empreendor ao kio do Janeiro por cerca de um mês, estará ausente às próxinae sessc̄os đo Colegiado, razão peḷa qual solicitava que suas faltas fossem justificadas. Retomando a palavra, 0 Senhor Presidente, tondo forzulado votos de boa-viagem ao Prof. Clóvis Morais Rēgo, colocou sua proposte em discussāo e votação senđo a mesma aprovada por unanimidade. Em soguila, o Conselheiro José da Silvoira solicitou a palavra, para, inicialmente, congratuler-se com a Secretaria da Cultura pelo belo trabalho que vem desenvolvendo no incentivo às manifestaçōes culturais de nosso Estado, mas também para lamen tar que entre as entidades contempladas con o apoio da SECULT para a dişão de suas revistas näo tivease sico incluŕco o Instituto Histōrico e Geogräfico do Fará, uma das mais antigas e atuantes instituicōes oul turais do Estado. Pedindo a palavra, o Prof. Paes Loureiro esclareceu 


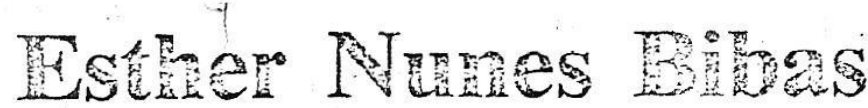

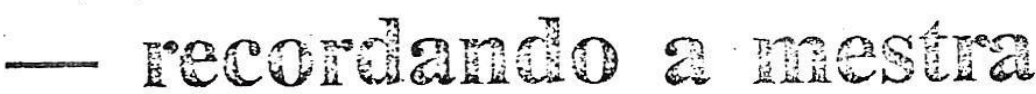

\section{Clóvis Meira}

Sempre procurei preservar a memória de meus antigos pro fessores. Recordo, com muito carinho, aquelas que me guiaram nas primeiras letrs ma solução de operaçöes fundamentais, que me ensinaram que existiam os oceanos, os continentes, os rios, me ensinaram que existiam os ocquenas cidades, ou me ensinaas montanhas, as grandes e pequenas cidades, ou me ensinaram e corrigiram a linguagem falada e escrita. A paciencia, dedicação, a bondade no acompannamento, da apos dia, ano após ano, de crianças "broncas", iluminando e norteando o espurito de cada uma 0 sacerdocio.

que o sacerdócio.
. Hoje dia 5 de Junho, viva fosse completaria 100 anos de nas

- Hoje, dia 5 de Junho, viva fosse completaria 100 anos de nas
cimento a notável educadora que foi Esther Nunes Bibas, figucimento a notável educadora que foi Esther Nunes Bibas, figura extraordinária de mulher, que além de ensinar crianças, criar e educar os filhos, levava os seus conhecimentos bem mais longe, escrevendo pela imprensa diária, publicardo livros, verse-
jando, fazendo das "cordas da lira" o seu encantamento e dos que a conheciam.

Esther Nures Bibas, além de inegável cultura, era professora por vocação. Nasceu e morreu professora, o que sabia fa zer e 0 de que mais gostava, transiormando e modelando as crianças de sua terra. Tinha no sangue essa destinação. Filha de professora, professora pelo desejo de transmitir, uma vez que nāo era diplomada, Constantina da Costa N'unes. alfabetizou ensinou inumeras geraçōes de vigienses. Ḿas rão ficava aí a forca do sangue Prima co professor Tomaz Nunes, homem dediça do sangue. Prima co proiessor Tomaz Nunes. homem dedcado as letras e do professor Bertolcio Nunes, ilustre homem de letras da Vigia. Esther, muito jovem, aspirando ser professora, depois de receber da propria máe a formaçao básica, veio para Belém, ingressou na Escola Normal, recebendo o Diploma de "Professor Normalista", em 21 de novembro de 1 acs, govemo de Augusto Montenegro. Tinha apenas 20 anos de icade Permaneceu no magistério ate os 70 anos, quando fol aposentada pela compulsoria, mas náo ensariliou as armas. Convidada, acompanhava turmas, participava ce bancas examinadoras e cooperava em todos os mavimentos empról da educaçăo e do ensino. E de sua autoria a letra do hino do Grupo Escclar "Pinto tiarques".

Esther Nures Bibas. nos instantes que deveriam ser de la zer eque ơveria estar "ủe pernas para o ar, que ninguém é de ferro",escrevia para os jornais; preparava livros, inolusive de dáticos, para os alunos do curso primário. com muites textos de autores nacionais consagrados, paraenses e brasileiros, acompanhados de vocabuiario e exercicios capituios destinados aos rudimentos da História do Brasil, de Higiene, das grandes fun çōes do corpo humano, inclusive principios de anatomia e fisiologia dos genitalia. A esses livros, didáticos por excelència, tive um exemplar da $8^{2}$ edição em mãos, eram preparadios de acordo com as séries, receberam o nome de "Päginas Brasileiras", impressos na editora "Brasil", em São Paulo.

Escrevia muito, grande parte destinacia à imprensa diária, principalmente à "A Provincia do Pará" e "Folha do Norte", algumas vezes ao "O Estado do Pará". Em 1958, através da edito ra paracnse $\mathrm{H}$. Barra, publicou um livro de poesias, as "Rimas do Coraçāo", cheio de encanto e de saudade, dos tempos descuidados da infância:

"O mundo nāo seria mundo

O mundo nāo seria mundo

"As rimas de meus versos

são rimas de alegria

porque dentro em minhalma

há flores de poesia,

que descem qual um véu

dos raios das estrèlas,

E Esther Bibas, ela mesma, quem diz, em uma espécie de prefácio:

"Venho de longe, de rios e igarapés de águas claras, estradas bonitas, luares estrelados, duma cidade flor, cheirosa a jasmim e salva rosa.

Venho de terra formosa de serenatas, violōes, açai, madrugadas lindas e crepusculos incomparáveis!

Sinto ainda, como num sonho feliz, a caricia do banho de água salgada, a alegria dos passeios, em barcos à vela, o encanto das margens verdes, pelas quais corre, assustado, o guará bonito de penas vermelhas.

Na saudade volto à minha infância venturosa, ouço alegre mente o sino da igreja, Soando Ave Maria, quando eu, criança ainda, rezava a virgem Mãe do Cèu!" E uma prosa poetica. Muito embora tenha se transíerido para Belem. muito jo vem, quase criança, nunca esqueceu a terra Natal. Eúucadora,

não descurava dás !etras e da poesia, sempre đé lápis na mão, mesmo quando ja em idade provecta:

"Eu quiz plantar a saudade

"Eu quiz plantat a saudade

só porque tento-a pirstada

dentro de meu coraça.
A saudade vem sorrindo

mas vem chorando também

brincando, às vezes, conosco,

faz recordarmos a!guem

Não pergunta, nảo discute

toda uma alma invade

o mundo nāo seria mundo

Em "Recordação", lembra a Vigia da infância:

"A manhã estava tão bonita quando, após tantos anos,

visitei minha cidade!

Sol dourado, verão vigiense!

casas diferentes...alegria.

A estrada...a ponte...o Arapiranga...

o peixe...os doces...o açai.

As vigilengas abrindo e fechando as asas...

Ao longe o porto Salvo e o Guajará...

Depois...minha visita à linda igreja,

isreja do tempo de menina.

de meu batismo e primeira comunhão!

Que saudade, meu Deus!..."

A professora Esther Nunes Bibas teve vida longa. Faleceu no dia 27 de o diploma, no governo Augusto Montenegro, não mais descan:çou, merecendo, por isso mesmo, justas horenagens. Dentre tantas, destaco a de ter sido escolhida "Professora do Ano, em 1959", homenagem da Sociedade Paraense de Educaçào, presidida pela proicssora Hijda Vieira, acontecimento registrado $\mathrm{em}$ uma plaqueta de prata. A saudosa professora Graziela Moura Ribeiro, em bcio discurso, fez a saudação em nome da Sociedàde. Foi agracieda com a medalha do "Centenário da Escola Nor-

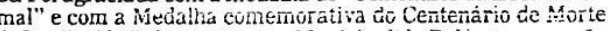
de Paulino de Brito. A Cámara Mlunicipai de Beièr., em sessẫo solene, the outorgou, em 19;0, o titulo de honra ao Mírito, aiem de outras manifestaçc̄es de carinho recebidas da legião de seus antigos alunos.

Dentre as suas produçōes literárias, ainda inéditas e que me foram confiadas pela sua filha e dedicada colaboradora, a iustre professora Tereza Nunes Bibas, encontrei um Romance, ape. nas iniciado, muitas poesias que nunca divulgou, inclusive acrósticos, dedicados aos amigos e aos médicos, como o velho colega e amigo Candido Pereira:

"Convosco, em vossa vida, Deus está

Amigo sempre vosso Éle seŕ

Amigo sempre vosso Ele se.

Deveis pois sem receio trabalhar!

Intenso é o movimento em vossa vída

Dêle porém irradia uma luz

Onde está o olhar santo de Jesus."

Ao cirurgião e renomado oftalmologista Joaquim Marinho de Queiroz dedicou "Máos de pluma", valendo reproduzir, ao me nos duas quadras:

"As mãos do Dr. Joaquim do peso não tem senōes. acarinham docemente,
nos atos de operaçōes.

Branquinhas e muito leves

trabalham bem, conscientes,

dâo auxilio aos pacientes."

Nas celebraçōes dos cern anos de nascimento de Esther Nunes Bibas, uma das mais notáveis mestras do passado. nào se se a Secretaria de Educação terá programado alguma solenidade em seu louvor, mas seria dc alvitre e de to o seu nome a uma das Escolas do Estado, se é que já nảo existe tantos e tão assinalados os serviços que prestou à criança e Deira do Para.

Deixou como herdeiros de sua vocação e de seu talento, os filhos: a prolessora Tereza Nuncs Bibas, educadora que segue os passos de sua saudosa màe: Gratuliano Ninnes Bibas. que de pois de dedicar o seu trabalho construtivo ao Exercito transmudou-se em um estudioso da história e do passado, devo iado preservacior ce nossas traciçires cuiturais, e mass Sulan-
ge, Silio, Heli, que nesta jora de saudade a recordam com filial amor. 


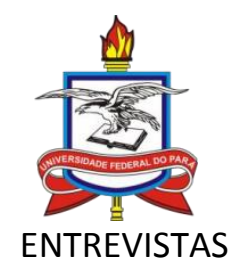

\section{Primeira Entrevista}

\section{UNIVERSIDADE FEDERAL DO PARÁ INSTITUTO DE CIÊNCIAS DA EDUCAÇÃO PROGRAMA DE PÓS-GRADUAÇÃO EM EDUCAÇÃO.}

\section{INSTRUMENTAL, $\mathrm{N}^{\circ} 1$}

\section{IDENTIFICAÇÃO}

Entrevistador: Ana Maria Maciel Corrêa.

Doutorado.

Na condição de aluna da Pós Graduação de Educação da UFPA-

- $\quad$ Endereço Institucional: PPGED- UFPA.

Entrevistados: Professor: Jaime

Bibas: Em 17/04/2015 Professora: Vania

Bibas Rio: Em 26/06/2016.

$\mathrm{Na} \quad$ condição de neto da professora Ester Nunes Bibas

entrevistadora. (1888-1972), sujeito- objeto, no projeto de Tese desta

Endereço Institucional: FAU - Faculdade de Arquitetura e Urbanismo - UFPA.

\section{Objetivos}

Considerando a escassez de dados e registros fragmentados sobre a trajetória que tornou a professora e escritora Ester Nunes Bibas, numa condição de invisibilidade no cenário da história da educação paraense. Nesse contexto de invisibilidade recorremos a relatos de familiares, com o objetivo de:

a) Acessar dados e fatos relacionados à trajetória e a atuação da professora Ester Nunes Bibas.

b) Identificar a partir do contexto familiar fatos que marcaram o protagonismo da mulher, da professora e da escritora Ester Nunes Bibas.

c) Trazer à tona pelo processo de rememoração informações que visibilize Quem foi Ester Nunes Bibas.

II. Dinâmica da Entrevista.

Primeiro contato.

Apresentação do projeto de Tese.

Escuta inicial. 
SERVIÇO PÚBLICO FEDERAL UNIVERSIDADE FEDERAL DO PARÁ INSTITUTO DE CIÊNCIAS DA

EDUCAÇÃO

PROGRAMA DE PÓS-GRADUAÇÃO EM EDUCAÇÃO ROTEIRO DE ENTREVISTA

Doutoranda: Ana Maria Maciel Corrêa Orientador: Prof. Dr. Carlos Jorge Paixão

\section{IDENTIFICAÇÃO: Segunda Entrevista.}

Entrevistado(a) Vania Bibas Rio.

Data; 20/12/2016.

Hora; 15.00 ás $17.00 \mathrm{~h}$.

Local: Edificio Pedro Teixeira, apt. 101.

Entrevistado: Jaime Bibas.

Data: 21/09/2017.

Hora: Das 10 às 12 horas

Local: Rua Pe. Eutíquio, Edifício Rio Sena.

\section{JUSTIFICATIVA:}

Considerando a localização de fontes escritas e documentais fragmentadas que expressam a incompletude da trajetória e do pensamento educacional de Ester Nunes Bibas, sujeito - objeto de nosso estudo propositivo de Tese, recorremos a utilização da técnica de entrevista como fonte de registro de familiares que pela convivência, retém memórias de dados, de fatos e de apreensões a respeito da maneira de ser, de atuar, de pensar e de escrever da Professora Ester Nunes Bibas. A senhora Vania Bibas Rios e o senhor Jaime Bibas, na condição de netos dessa professora, com quem manteveram uma relação de proximidade desde criança à fase adulta. Suas lembranças transcritas em relatos escritos assumem a importância referencial para a construção da trajetória pessoal e intelectual desta educadora paraense.

\section{OBJETIVO}

Identificar nos relatos de Jaime Bibas, fatos, dados e apreensões sobre a maneira de ser, viver, atuar, de pensar e de escrever da professora Ester Nunes Bibas; enquanto informações que desvelem ou retratem a mulher, a professora e a escritora imersa no contexto sociocultural da Cidade de Belém do Pará. 


\section{QUESTÕES MEDIADORAS.}

Contexto Familiar.

Quem eram os "Nunes" de Vigia?

De que maneira a família "Nunes" influenciou na trajetória de Ester Nunes Bibas

Como Ester Nunes transita sua vida de esposa, mãe e professora entre os "Nunes", família de or "Bibas", a família ampliada pelo casamento?

4.5 Qual o retrato de Ester que permeiam suas lembranças?

4.6 Qual a importância da religiosidade na Vida de Ester Nunes Bibas?

O Lugar da Educação na Vida de Ester Nunes Bibas.

O que levou Ester Nunes Bibas a se tornar normalista e professora?

A professora Ester Nunes na cotidianidade da família falava de sua passagem pela Escola Normal? Sua importância, suas dificuldades no período de formação?

Quando a professora e onde a professora Ester Nunes inicia sua carreira no Magistério? Na esfera privada e na Rede de Ensino Público.

Que ideal de Educação era defendido por Ester Nunes Bibas?

".

Qual seria o papel do ensino e da escola para Ester Nunes Bibas?

A Participação Ester Nunes Bibas no Movimento pelo Voto feminino:

Como a participação de Ester neste movimento era visto pela família "Nunes Bibas”?

4.5 Ester em alguma ocasião comentou sobre sua filiação a esse movimento nitidamente feminista? Suas razões e seus posicionamentos. 
Escritora de livros didáticos "Páginas Brasileiras"

Que razão ou razões levaram Ester Nunes Bibas a escrever livros didáticos para o ensino primário? Já respondido na questão 4.4 .

Em que período Ester escreve essa coletânea didático-pedagógica? - Sem informação.

Como eram esses livros em seu formato e conteúdo? Que lembranças você tem dos livros da sua avó? Você estudou neles?

Que mensagens importantes Ester Nunes Bibas fez circular através de seus livros?

A professora comentava sobre os autores que gostava de ler por subsidiarem seu saber e suas práticas como educadora?

- Sem informações

4.17 A professora Ester Nunes Bibas mantinha relações de proximidade com professores e professoras do seu tempo? Quais eram mais presentes em ciclo profissional ou de amizade? 